QL

696

C23012

1914

BI RDS

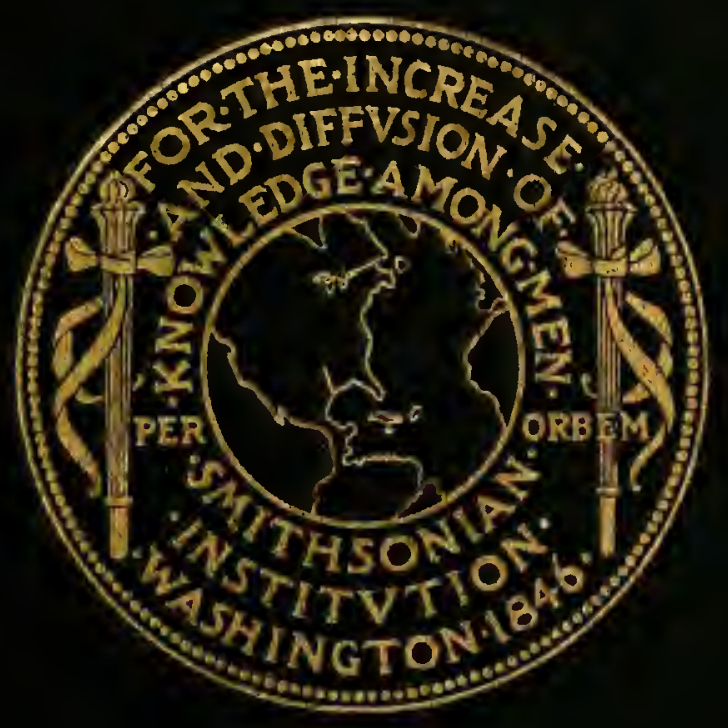







$$
\text { ofrion of }
$$





\title{
A MONOGRAPH OF THE GENUS CHORDEILES
} SWAINSON, TYPE OF A NEW FAMILY OF GOATSUCKERS

\author{
BY \\ HARRY C. OBERHOLSER \\ Of the Biological Survey, United States \\ Department of Agriculture
}

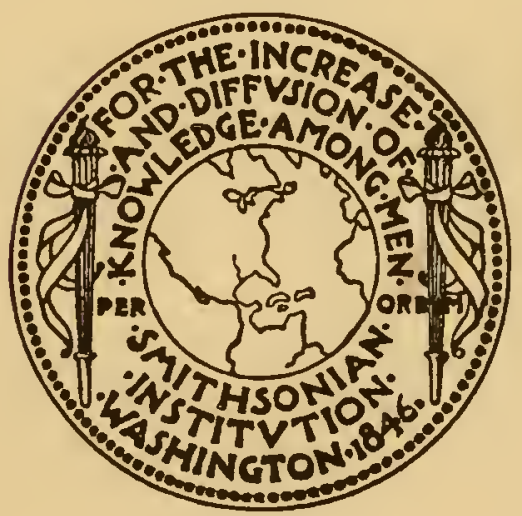


BULLETIN OF THE UNITED STATES NATIONAL MUSEUM.

ISSUED APRIL 6, 1914.

II 


\section{ADVERTISEMENT.}

The scientific publications of the United States National Museum consist of two series, the Proceedings and the Bulletins.

The Proceedings, the first volume of which was issued in 1878, are intended primarily as a medium for the publication of original, and usually brief, papers based on the collections of the National Museum, presenting newly-acquired facts in zoology, geology, and anthropology, including descriptions of new forms of animals, and revisions of limited groups. One or two volumes are issued annually and distributed to libraries and scientific organizations. A limited number of copies of each paper, in pamphlet form, is distributed to specialists and others interested in the different subjects as soon as printed. The date of publication is printed on each paper, and these dates are also recorded in the table of contents of the volumes.

The Bulletins, the first of which was issued in 1875 , consist of a series of separate publications comprising chiefly monographs of large zoological groups and other general systematic treatises (occasionally in several volumes), faunal works, reports of expeditions, and catalogues of type-specimens, special collections, etc. The majority of the volumes are octavos, but a quarto size has been adopted in a few instances in which large plates were regarded as indispensable.

Since 1902 a series of octavo volumes containing papers relating to the botanical collections of the Museum, and known as the Contributions from the National Herbarium, has been published as bulletins.

The present work forms No. 86 of the Bulletin series.

Richard RathbUn, Assistant Secretary, Smithsonian Institution, In charge of the United States National Museum.

Washivgton, D. C., March 12, 1914. 



\section{TABLE OF CONTENTS.}

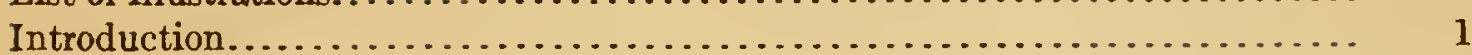

Genus Chordeiles............................................ 3

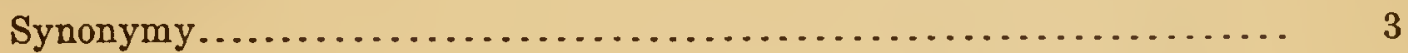

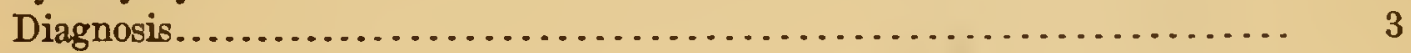

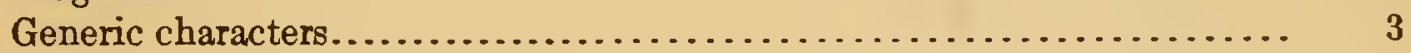

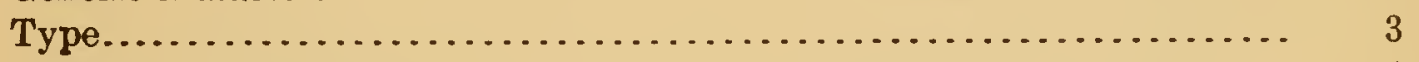

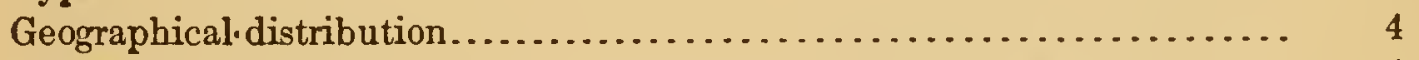

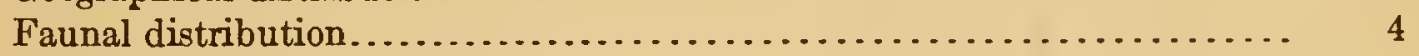

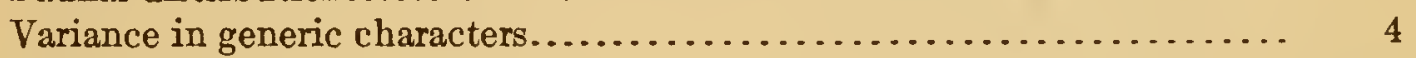

Relationships....................................... 6

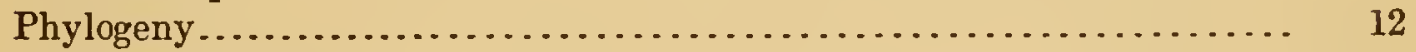

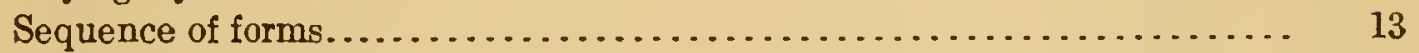

Species and subspecies.................................... 15

Recognition of subspecies................................. 16

Identification of specimens.................................. 17

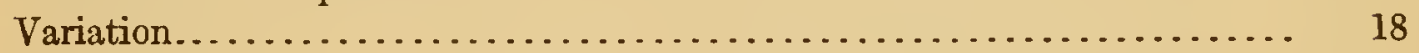

General habits............................................. 19

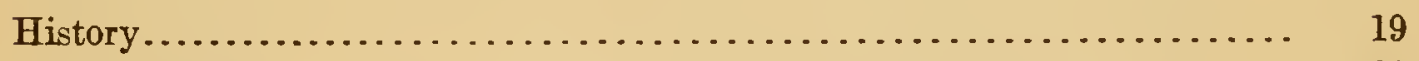

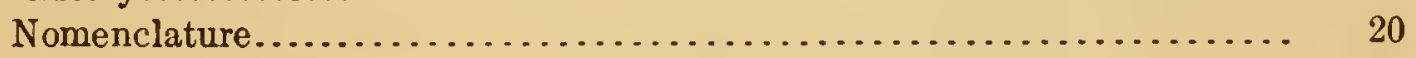

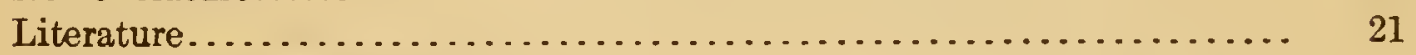

Key to species and subspecies............................. 22

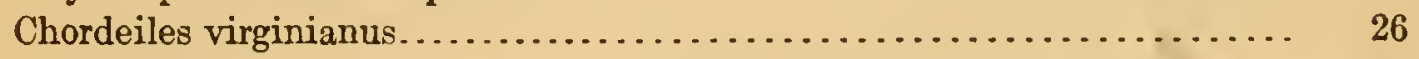

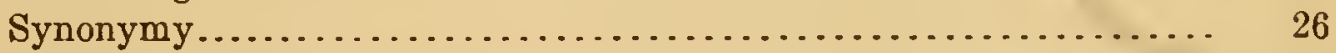

Specific characters (adult male)......................... 26

Adult female......................................... 27

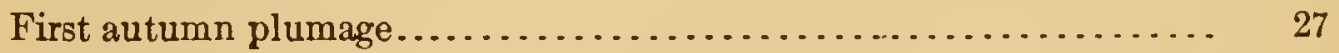

Juvenal plumage.................................... 27

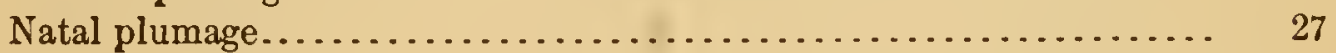

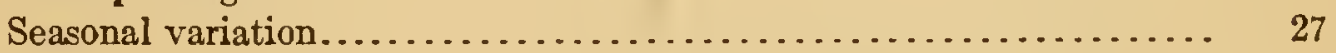

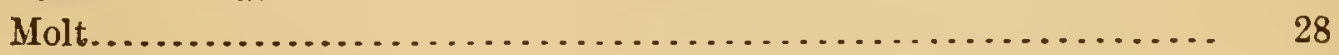

Individual variation...................................... 28

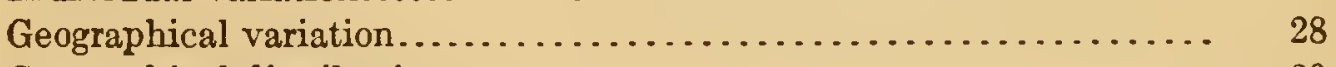

Geographical distribution............................. 30

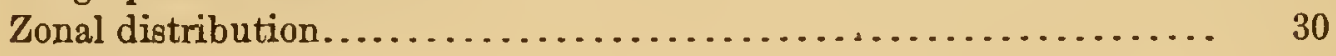

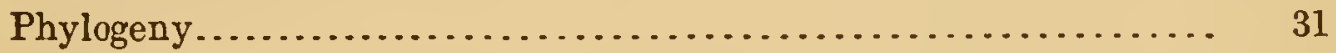

Migration........................................... 32

Habits................................................ 33

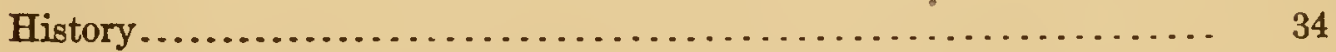

Chordeiles virginianus virginianus....................... 35

Chordeiles virginianus hesperis........................ 46

Chordeiles virginianus sennetti......................... 52 
Genus Chordeiles-Continued.

Chordeiles virginianus-Continued.

Page.

Chordeiles virginianus howelli............................ 57

Chordeiles virginianus henryi.............................. 65

Chordeiles virginianus aserriensis....................... 71

Chordeiles virginianus chapmani.......................... 75

Chordeiles virginianus vicinus............................. 80

Chordeiles virginianus minor............................ 82

Table of comparative measurements....................... $\quad 86$

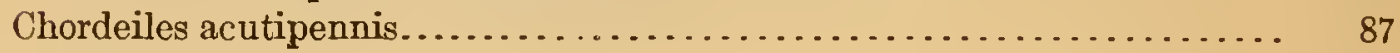

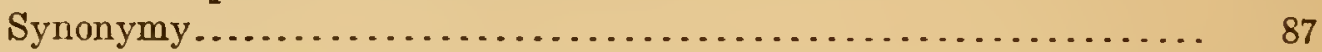

Specific characters (adult male)....................... 87

Adult female............................................... 87

First autumn plumage................................ 87

Juvenal plumage.................................... 88

Nestling plumage..................................... 88

Seasonal variation..................................... 88

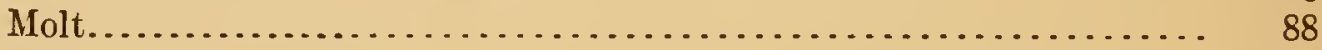

Individual variation.................................. 88

Geographical variation................................. 89

Geographical distribution................................ 90

Zonal distribution...................................... 91

Phylogeny............................................. 91

Migration ......................................... 92

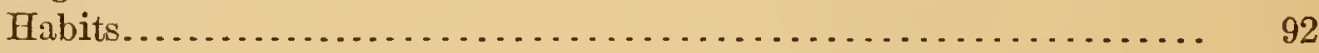

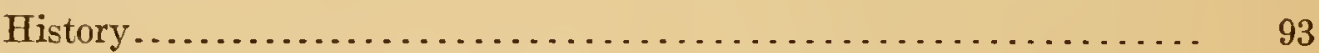

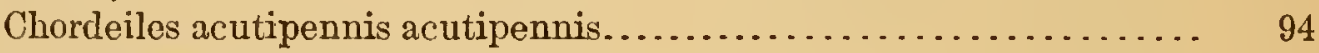

Chordeiles acutipennis exilis............................ 98

Chordeiles acutipennis micromeris...................... 100

Chordeiles acutipennis texensis........................ 103

Chordeiles acutipennis inferior......................... 109

Table of comparative measurements...................... 112

Chordeiles rupestris................................... 113

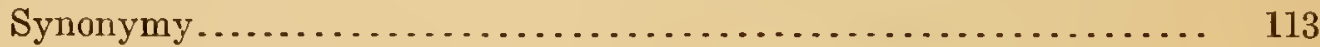

Specific characters (adult male).......................... 113

Adult female........................................ 113

Remarks........................................... 113

Geographical distribution............................. 113

Habits............................................. 114

Phylogeny .............................................. 114

History ................................................. 114

Chordeiles rupestris rupestris............................ 114

Chordeiles rupestris xyostictus........................ 116

Chordeiles rupestris zaleucus......................... 118

Index .............................................. 121 


\section{LIST OF ILLUSTRATIONS.}

Phate 1, fig. 1 Page.

2, fig. 1.-. Palatal surface of Antrostomus carolinensis............ 120

2.-Palatal surface of Setochalcis vocifera vocifera ........... 120

3.-Breeding ranges of the subspecies of Chordeiles virginianus....... 120

4.-Breeding ranges of the Central American and North American sub- 120 species of Chordeiles acutipennis................... 120

5.-Breeding ranges of the South American subspecies of Chordeiles 120 acutipennis ............................... 120

6.-Breeding ranges of the subspecies of Chordeiles rupestris........ 120 



\title{
A MONOGRAPH OF THE GENUS CHORDEILES SWAIN- SON, TYPE OF A NEW FAMILY OF GOATSUCKERS.
}

\author{
By Harry C. Oberholser, \\ of the Biological Survey, United States Department of Agriculture.
}

\section{INTRODUCTION.}

The present study of the Caprimulgine genus Chordeiles found its origin in the attempt to identify the nighthawlss of Texas. It soon became evident that nothing short of a thorough revision of the two North American species, Chordeiles virginianus and Chordeiles acutipennis, would produce anything like satisfactory results. This was finally undertaken, partly at the instance of Mr. Robert Ridgway; and the only other species of the genus, Chordeiles rupestris, has been included for the sake of completeness. By reason of the complicated and almost infinite variations due to sex, age, individuals, and geographic areas, the present group is one of the most difficult of all North American birds; and its elucidation has involved the expenditure of an incredible amount of time and labor.

The material available consists altogether of 1,165 specimens, including the types of most of the valid forms (excepting Chordeiles virginianus virginianus, Chordeiles virginianus aserriensis, Chordeiles virginianus minor, Chordeiles acutipennis acutipennis, Chordeiles acutipennis exilis, and Chordeiles rupestris rupestris), and of one synonym, Chordeiles gundlachii Lawrence. These specimens are distributed among the three species as follows: Chordeiles virginianus, 780; Chordeiles acutipennis, 379; Chordeiles rupestris, 6 .

This material has been derived from the following sources: The United States National Museum, including the Biological Survey collection; the American Museum of Natural History; the Academy of Natural Sciences of Philadelphia; the Museum of Comparative Zoölogy in Cambridge, Massachusetts, including the collection of Messrs. E. A. and O. Bangs; the Carnegie Museum of Pittsburgh, Pennsylvania; the Museum of Vertebrate Zoology in Berkeley, California; the Field Museum in Chicago, Illinois; the Victoria Memorial Museum in Ottawa, Ontario; and the private collections of Mr. Joseph Grinnell, Mr. F. Seymour Hersey, Dr. G. C. Rinker, 
Dr. L. B. Bishop, Mr. J. H. Fleming, and Mr. A. C. Bent. To the authorities of these institutions, to the curators of their bird collections, and also to the gentlemen above mentioned, the writer wishes here to express his thanks for their courtesies. Moreover, to Dr. Charles W. Richmond, of the United States National Museum, he is as usual indebted for many kindnesses in connection with the present investigation. The drawings of skulls on plates 1 and 2 were executed by Miss R. G. Collette.

For the names of colors Mr. Robert Ridgway's recently published Color Standards and Nomenclature ${ }^{1}$ has been adopted as the standard.

The numbering of the primaries is from the outermost, since this is so much more convenient in descriptive ornithology, although, of course, indefensible from a morphological standpoint.

Detailed synonymy has been omitted under the forms of both Chordeiles virginianus and Chordeiles acutipennis, because such synonymy would be merely a duplication of that in Mr. Ridgway's Birds of North and Middle America, part 6, ${ }^{2}$ which is soon to appear.

All measurements are in millimeters. The specimens used in the average measurements under each subspecies, and with which comparisons are made, are taken just as far as possible from typical specimens-that is, from examples best exhibiting the differential characters. In the tables of detailed measurements all the birds used in the diagnostic averages, as well as all other than adult birds, are indicated by reference marks. The various dimensions of which use is made in the following pages have been taken as follows:

Length of wing.-Measured in a straight line from the bend of the closed wing to the end of the longest primary, with the primaries in their natural position-that is, not straightened.

Length of tail.-Taken with dividers from the point of insertion of the middle rectrices to the tip of the longest.

Exposed culmen.-Measured in a straight line from the beginning of the feathers on the culmen to the tip of the maxilla-that is, the chord of the exposed culmen.

Length of tarsus. - A straight line from the center of the heel joint on the posterior side to the middle of the joint between the metatarsus and the middle toe on the anterior side.

Middle toe.-Measured along the upper side from the middle of the joint between the metatarsus and the middle toe to the base of the uncovered claw.

\footnotetext{
1 Ridgway, Color Standards and Color Nomenclature, 1912 (=January 16, 1913), pp. $(1-4)$; i-iv ; 1-44; frontispicee; pls. 1-53; Washington, D. C.

${ }^{2}$ Bull. U. S. Nat. Mus., No. 50, pt. 6, 1914. In this volume Mr. Ridgway has adopted from my manuseript my conclusions regarding the subspecies of Chordeiles; but he has not seen the introductory portion of the present bulletin, pages 1-23.
} 


\section{Genus CHORDEILES Swainson.}

Chordeiles Swainson, Fauna Bor.-Amer., vol. 2, 1831 (1832), p. 496 (type, by original designation and monotyps, "Chordeiles virginianus [Caprimulgus americanus, Wils.]" qui Caprimulgus virginianus, Gmelin).

Chordeilus "Swains." Gray, List Genera Birds, 1840, p. 7 (type, by original designation and monotypy, Caprimulgus virginianus, Gmelin).

Microrhynchus Lesson, L'Echo du monde Savant, July 16, 1843, col. 109 (type, by monotypy, Caprimulgus exilis Lesson) (nec Microrhynchus Dejean [Megerle MS.], 1821, Coleoptera ; Bell, 1835, Crustacea).

Chordiles "Swains. 1831" Tschud, Untersuch. Fauna Peruana, Ornith., 1846, p. 21 (type, by monotypy, "Ch. semitorquatus Cab. MSS. [=] Cap. pruinosus Licht. Mus. Berol. vid. Tsch. Consp. av. Nro. 37," qui Caprimulgus exilis Lesson).

Chordediles Cabanis [Wiegmann's] Archv fiir Naturg., XIII, vol. 1, Norember, 1847, p. 346 (nom. emend. pro Chordeiles Swainson).

Ramphaoratus Bonaparte, Rivista Contemporanea, rol. 9, February, 1857, p. 215 (p. 9 of reprint), (type, by virtual monotypy, Capvimulgus cxilis Lesson).

"Chordedilus 1861 Cab." Gray, Hand-list Gen. Spec. Birds, rol. 1, 1869, p. 61 (in synonymy).

Diagnosis.-Similar to Nyctiprogne Bonaparte, but bill stronger and broader basally; nostrils more rounded, more exposed, more tubular, and opening more obliquely, less laterally; tertials longer. Similar to Nannochordeiles Hartert, ${ }^{1}$ but wing more pointed (less rounded), the third primary (counting from the outermost) much shorter than the first and second, instead of about the same length; tail more deeply emarginate.

Chars. gen.-Medium-sized, long-winged Chordeilidae; bill rather small and weak, decidedly hooked; nostrils rather large, strongly tubular, and opening obliquely; no long or conspicuous rictal bristles; no occipital, frontal, or nuchal crest; tail rather long, more than half (about 55-60 per cent) of wing, emarginate, the outer rectrices longest, all of moderate width, rounded or squarish at tips; wing long and pointed, the first or second primary (counting from the outermost) longest, the third shorter than either; tertials reaching nearly to the tip of sixth primary, or beyond; secondaries short, the shortest one not reaching the tips of primary coverts or not extending far beyond; feet rather weak; tarsus feathered in front for about the proximal third; tarsus usually shorter than middle toe without claw; outer toe slightly shorter than inner toe; exposed culmen about half the length of tarsus. ${ }^{2}$

Type-Caprimulgus virginianus Gmelin (by original designation and monotypy).

1 Vannochordeiles Hartert, Ibis, July, 1896, p. 374 (type, Chordeiles pusillus Gould).

2 No osteological characters appear in this diagnosis, because proper comparative material of the most closely related genera is not avallable. Consult, however, pp. 6-9 of the present bulletin. 
Geographical distribution.-Nearly all of South America, the West Indies, Central America, and North America excepting the far northern part.

Faunal distribution.-All or parts of the Patagonian, Brazilian, Subandean, Amazonian, Antillean, and Central American subregions of the Neotropical Region; the Sonoran and Boreal subregions of the Nearctic Region; but avoiding the barren grounds and alpine summits of the circumpolar Arctic Region.

Variance in generic characters.-No two of the three species at present composing this genus, Chordeiles virginianus, Chordeiles acutipennis, and Chordeiles rupestris, are exactly alike in structural characters, although they all agree with the generic diagnosis above given. In Chordeiles virginianus, type of the genus, the first (outermost) primary is usually longer than the second, occasionally about equal, but rarely shorter; the secondaries relatively short, the shortest usually not reaching the tips of the primary coverts by at least 5 millimeters, often much more; and the distance from the bend of the folded wing to end of shortest secondary generally less than from the latter point to the tip of fourth primary (counting from the outermost); outer pair of rectrices relatively narrow and their tips much rounded; maxillo-palatines relatively rather broad and somewhat triangular; anterior processes of the palatines relatively rather broad and strong; vomer very narrow; pterygoids with an antero-exterior angle which approaches the palatine; interorbital region very broad; and the ridges on median portion of frontals not strongly developed.

In Chordeiles acutipennis, however, the outermost (first) primary is usually shorter than the second, occasionally about equal or longer; secondaries longer than in Chordeiles virginianus, the shortest usually not falling short of the tips of the primary coverts by more than 3 millimeters, commonly longer or at least not shorter than the primary coverts; the distance from the bend of the folded wing to the end of the shortest secondary greater, usually decidedly so, than the distance from the latter point to the end of the fourth primary; outer pair of rectrices relatively broader than in Chordeiles virginianus, and their tips more truncate; maxillo-palatines relatively rather narrower and more elongated; anterior processes of the palatines more slender; vomer rather broader; pterygoids without a distinct antero-exterior angle; interorbital region somewhat narrower; and the ridges on median portion of frontal bones more conspicuous.

In Chordeiles rupestris the first (outermost) primary is longer than the second; the tertials are relatively longer than in Chordeiles virginianus and Chordeiles acutipennis, usually reaching or overreaching 
the tip of the sixth primary; the secondaries as in Chordeiles acutipennis; the tail-feathers as in Chordeiles virginianus; skull not examined.

It is thus apparent that Chordeiles virginianus and Chordeiles acutipennis differ in structural characters, which, were they trenchant and constant, instead of only average, would clearly warrant generic separation. But Chordeiles rupestris appears to be practically intermediate between these two species, or, to be more exact, partakes of the structural characters of both, though in pattern of coloration it is widely different from either. In the small series examined the characters of Chordeiles mupestris, as above given, are pretty constant, but in a larger series greater range of variation would doubtless be evident. The present case, therefore, might appear at first sight to be an ideal one for the profitable employment of subgenera; since if anything more than personal caprice is to determine what is to be considered a genus and what a subgenus, it is probably to be found in the principle of intergradation, a principle of general acceptance as applied to species and subspecies; by which a full genus would be a group trenchantly defined by structural characters, even though these differences be relatively slight; and a subgenus one the structural diagnostic characters of which intergrade through intermediate species with some other group, even if the extreme differences be relatively great. In the present case, however, we have a rather peculiar and unusual condition, for while there is more or less connection between the three species which would, by the above criterion, possibly form three subgenera, the intergradation is complicated by the fact that all the structural characters separating the species are, in Chordeiles virginianus and Chordeiles acutipennis at least, decidedly inconstant. To consider instable structural characters of this sort as the basis for subgeneric separation seems to the writer certainly undesirable.

These birds have, however, a decided interest for the student of evolution, because it is very evident that we have in these three species a case of genera in process of development. Unfortunately we have not sufficient osteological material to determine the amount of variation in cranial characters; but to show, as far as possible by actual figures, the constancy of the external structural characters separating Chordeiles virginianus and Chordeiles acutipennis, and thus to indicate the state of their relative evolutionary divergence, the writer examined a large number of specimens of each species and counted the individuals showing the different variations of the two most tangible characters, $i$. e., the comparative length of the outermost primary, and the relative length of the shortest secondary as com- 
pared with the primary coverts. A tabulation of these results is given herewith:

\begin{tabular}{|c|c|c|}
\hline Characters. & $\begin{array}{l}\text { Chordeilcs vir- } \\
\text { ginianus. }\end{array}$ & $\begin{array}{c}\text { Chordeiles acuti- } \\
\text { pennis. }\end{array}$ \\
\hline 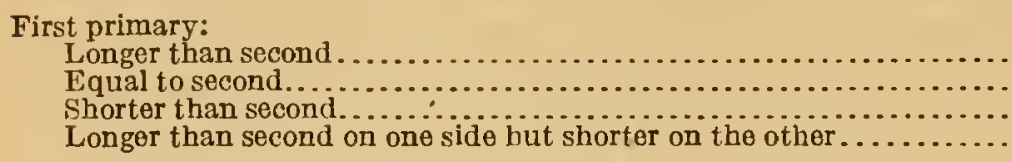 & $\begin{array}{r}90(85.7 \%) \\
7(6.6 \%) \\
5(4.9 \%) \\
3(2.8 \%)\end{array}$ & $\begin{array}{l}12(11.5 \%) \\
11(10.6 \%) \\
78(75.0 \%) \\
3(2.0 \%)\end{array}$ \\
\hline Total number of birds examined. & 105 & 104 \\
\hline 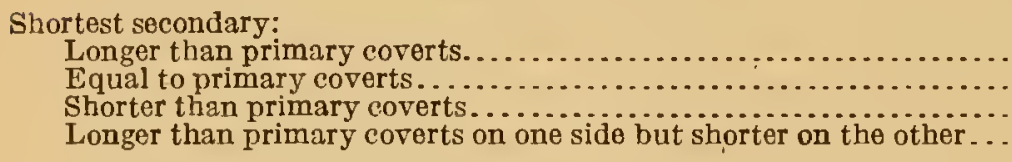 & $\begin{array}{r}6(5.3 \%) \\
3(2.5 \%) \\
103(91.9 \%) \\
0(0.0 \%)\end{array}$ & $\begin{aligned} 92 & (82.9 \%) \\
8 & (7.2 \%) \\
9 & (8.1 \%) \\
2 & (1.8 \%)\end{aligned}$ \\
\hline Total number of birds examined.. & 112 & 111 \\
\hline
\end{tabular}

The above figures are based on so large a number of specimens that their percentage would probably not be materially changed by the examination of a greater number. From these percentages it will be seen that Chordeiles virginianus is more stable in its structural characters, at least in the two here considered, than is Chordeiles acutipennis; or, in other words, is farther along in its differentiation. Thus, in Chordeiles virginianus the first primary is longer than the second in 85.7 per cent of the specimens, while in Chordeiles acutipennis it is shorter than the second in only 75 per cent. Also in Chordeiles virginianus the shortest secondary is shorter than the primary coverts in 91.9 per cent; in Chordeiles acutipennis it is longer than the primary coverts in only 82.9 per cent. Further comparisons can easily be made from the table. Of the two characters here exploited, the length of the secondaries thus seems to be the better. There does not seem to be any difference in these structural characters among the different subspecies of either Chordeiles virginianus or Chordeiles acutipennis; and the above percentages of the two species include representatives of various subspecies indiscriminately.

Relationships.-The genus Chordeiles has always without question been placed in the family Caprimulgidae. A careful examination and comparison, however, of a series of skulls of Chordeiles virginianus and the skull of Chordeiles acutipennis texensis, with crania of Antrostomus carolinensis, Setochalcis ${ }^{1}$ vocifera, Phalaenoptilus nuttallii, and Nyctidromus albicollis merrilli, and with Huxley's figure of the skull of Caprimulgus europaeus ${ }^{2}$ (see pl. 1, fig. 1), reveal differences that make advisable, indeed even necessary, the removal of Chordeiles from the family Caprimulgidae. So far as cranial characters are concerned, Chordeiles virginianus (see pl. 1, fig. 2) and Chordeiles acutipennis are generically identical, since aside from some unimportant details, which are surely not of more

2 Proc. Zool. Soc. Lond., 1867, p. 453. 
than specific value, the skulls of these two species are the same. Both Chordeiles virginianus and Chordeiles acutipennis are perfectly desmognathous, ${ }^{1}$ as the figure of the former ${ }^{2}$ and the previously published figure of the latter ${ }^{3}$ clearly show, which character alone in such a complete exemplification should be sufficient as a basis for recognition of a distinct family. In both species the maxillo-palatines meet on the median line and become ankylosed, at least in old birds, with each other and with the vomer. There is thus no doubt about their complete desmognathism. Besides this, however, Chordeiles differs from all the above-mentioned genera of Caprimulgidae in many other respects, as follows: Premaxillary (to cranio-facial suture) relatively as well as actually much shorter, only 37 per cent of the total length of the skull, whereas in Setochalcis vocifera it is 49 per cent; this, together with the actually as well as relatively much higher braincase, giving to the skull in general a curious humpbacked, pug-nosed appearance; interorbital portion of frontal region very much broader, medially depressed and furrowed, but laterally rising in a crest to the edge of the orbits, while in the other genera examined just the reverse is the case, the frontal region being rather inflated, with the orbital edges more or less rounded; vomer relatively narrow and slender; maxillo-palatines subtriangular instead of more or less strap-like or shoe-shaped; middle portion of palatines much broader, the lateral outline thus less constricted medially, more nearly straight, giving to the posterior portion a decidedly less flaring effect; antero-internal processes of palatines reaching to the maxillo-palatines; palatal opening between the halves of the premaxillary much smaller, narrower, and somewhat narrowly triangular instead of oval in shape; gall bladder absent; ${ }^{*}$ rictal bristles wanting.

Unfortunately I have been unable to examine the skulls of the South American genera commonly referred to the Caprimulgidae, so that it is impossible to determine with exactness which of the above characters are to be regarded as supergeneric. Doubtless some of them will prove, upon examination of all the remaining groups, to be merely generic. The same lack of material render's doubtful the precise limits of the family group which includes Chordeiles. The nearest ally of Chordeiles is without much doubt Nannochordeiles Hartert, and this certainly belongs to the same family, while Nyctiprogne is probably also not distantly related. From external characters it would perhaps be better to include both Lurocalis and

\footnotetext{
1 The statement of Beddard (Structure and Classification of Birds, 1898, p. 239) that in Chordeiles virginianus the maxillo-palatines do not meet across the vomer is doubtless a slip or the result of examining an imperfect, abnormal, or immature sliull, for in every one of the half dozen skulls we have examined these bones meet just as in Chordciles acutipennis.
}

2 See plate 1, fig. 2.

shufeldt, Proc. Zool. Soc. I,ond., 18.55, pl. 59, fig. 4.

4 According to Beddard, Structure and Classification of Birds, 1898, p. 242. 
Podager, though the latter is aberrant. The salient reliable differential characters of the two families here most concerned are in part well shown on plates 1 and 2, accompanying the present paper, and are also all given in the tabular exposition below:

\begin{tabular}{|c|c|c|}
\hline Characters. & Caprimulgidae. & Chordeilidae. \\
\hline Palate... & Schizognathous $1 . .$. & Desmognathous. \\
\hline Vomer... & Broad................. & Narrow. \\
\hline Maxillo-palatines... & Strap-like, hook-like, or shoe-shaped.. & Subtriangular. \\
\hline Palatines......... & $\begin{array}{l}\text { Medially narrow, with lateral outline } \\
\text { much constricted. }\end{array}$ & $\begin{array}{l}\text { Medially broad, with lateral outline } \\
\text { little constricted. }\end{array}$ \\
\hline $\begin{array}{l}\text { Antero-internal proces- } \\
\text { ses of palatines. }\end{array}$ & $\begin{array}{l}\text { Widely separated from maxillo-pala- } \\
\text { tines. }\end{array}$ & Reaching to maxillo-palatines. \\
\hline Premaxillary..... & $\begin{array}{l}\text { Long; } 49 \text { per cent of total length of } \\
\text { skull. }\end{array}$ & $\begin{array}{l}\text { Short; } 37 \text { per cent of total length of } \\
\text { skull. }\end{array}$ \\
\hline Braincase.. & Low..................................... & High. \\
\hline Frontals.... & Medially convex....... & Medially concsve. \\
\hline Gall bladder... & Present.............. & Wanting. \\
\hline Rictal bristles.... & Present $2 . \ldots \ldots \ldots \ldots \ldots$ & Wanting. \\
\hline Included genera.... & Systellura Ridgway....... & Chordeiles Swainson. \\
\hline & Stenopsis Cassin........... & Nannochordeiles Hartert. \\
\hline & Antiurus Ridgway ....... & Nyctiprogne Bonaparte. \\
\hline & Nyctipolus Ridgway......... & Lurocalis Cassin. \\
\hline & Setochalcis Oberholser $4 . . .$. & Podager Wagler.8 \\
\hline & Setopagis Ridgway......... & \\
\hline & Phalaenoptilus Ridgway.... & \\
\hline & Nyctagreus Nelson........... & \\
\hline & Otophanes Brewster........... & \\
\hline & Nyctiphrynus Bonaparte 5. & \\
\hline & A ntrostomus Bonaparte.... & \\
\hline & Nyctidromus Gould............ & \\
\hline & Siphonorhis Sclater...... & \\
\hline & Caprimulgus Linnæus ... & \\
\hline & Eleothreptus Gray.......... & \\
\hline & Cosmetornis Gray....... & \\
\hline & Macrodipleryx Swainson... & \\
\hline & Scotornis Swainson....... & \\
\hline & Hydropsalis Wagler.... & \\
\hline & Macropsalis Sclater......... & \\
\hline & Lyncornis Gould ${ }^{8} . . . . . .$. & \\
\hline & Eurostopodus Gould $3 . . . .$. & \\
\hline
\end{tabular}

1 By some authors, as, for instance, Beddard and Parker, the Caprimulgidae are considercd schizognathous, although by Huxley originally placed in the aegithognathous series. It is, of course, true that they are not typically schizognathous, having some aegithognathous characters; but it is also evident that, all things considered, they are much nearer the schizognathous than to the aegithognathous type.

2 Except in the genera Lyncornis and Eurostopodus.

- Provisionally included.

- See p. 11.

- Nyctiphrynus Bonaparte (Rivista Contemporanea, vol. 9, February, 1857, p. 215 [p. 9 of reprint]) contained originally three species: Caprimulgus ocellatus Tschudi (type of Ptilonycterus Ridgway, 1912); Caprimulgus nuttallii Audubon (type of Phalaenoptilus Ridgway, 1880); and Caprimulgus guianensis Gmelin (=Caprimulgus albicollis Gmelin) (type of Nyctidromus Gould, 1838). The first species was thus last made type of a new genus; and this genus Nyctiphrynus was restricted by Gray (Hand-List Gen. and Spec. Birds, vol. 1, 1869, p. 59) to the same bird, Caprimulgus occllatus Tschudi. I, therefore, now designate Caprimulgus ocellatus Tschudi as the type of Nyctiphrynus Bonaparte, and Ptilonycterus Ridgway consequently becomes its synonym. 
The genera in the above lists are arranged in what seems to be their natural order, but manifestly the osteology of all must be studied before a finally satisfactory sequence can be devised. The Chordeilidae, by reason of their desmognathism and the loss of the gall bladder, seem to be a less ancient and less primitive group than the Caprimulgidae. The full and formal diagnosis ${ }^{1}$ of the Chordeilidae, based, of course, almost entirely on Chordeiles, is as follows:

\section{CHORDEILIDAE, new family.}

Caprimulgi with sternum one-notched on each side; carotids two; syrinx tracheo-bronchial; oil gland present; cæca present; cervical vertebræ 13; fourth (outer) toe with but four phalanges; claw of middle toe pectinated; muscular formula AXY; biceps slip present; expansor secondariorum absent; glutaeus primus extending over biceps; gall bladder lacking; powder downs absent; skull broad, the zygoma spreading and distinctly angular, the interorbital breadth great; braincase high; frontals medially concave; premaxillary short, only 37 per cent of total length of skull; palate perfectly desmognathous; maxillo-palatines relatively broad and subtriangular, ankylosed with each other and with the vomer; palatines much inflated posteriorly and across their middle portion, not meeting except at their hind ends, the foramina in their middle portion small, their lateral outines little constricted medially, their antero-external processes long and slender, their antero-internal processes reaching to the maxillo-palatines; vomer long, slender, and pointed at its anterior end; basipterygoid processes well developed; rictal bristles wanting.

The type genus of this family is Chordeiles Swainson.

The geographical range of the family is as follows: South America, Central America, North America, and the West Indies; thus practically all of the Neotropical and Nearctic zoogeographical regions.

The genera to be included in the family Chordeilidae have already been discussed. ${ }^{2}$

In making comparisons of the skulls of Chordeiles with those of several genera of true Caprimulgidae some interesting facts concerning the latter family were discovered. The current genus Antrostomus Bonaparte, by many authors considered to include a wellknown group of American species, by others united with Caprimul$g u s$, is not only perfectly distinct from the latter, but is itself divisible into two very divergent groups. In the following comparisons the skulls of only three species, Caprimulgus europaeus, Antrostomus

1 Characters common to all Caprimulgi are omitted.

2 See p. 8.

$13732^{\circ}-$ Bull. $86-14-2$ 
carolinensis, and "Antrostomus" vociferus, have been used, but skins of a considerable number of other American and Old World species have been examined. All comparisons with Caprimulgus, however, are entirely with Caprimulgus europaeus (see pl.1, fig. 1), the type of Caprimulgus Linnæus, ${ }^{1}$ for it is plain that the genus Caprimulgus, even restricted to Old World species, is a very heterogeneous group, and much in need of careful revision, for which the writer has at present neither time nor adequate available material.

In the first place, Antrostomus carotinensis (see pl. 2, fig. 1), the type by subsequent designation ${ }^{2}$ of the genus Antrostomus Bonaparte, ${ }^{3}$ and apparently the only member of this group as I now restrict it, differs greatly from Caprimulgus in both cranial and external characters, and is really more closely related to Nyctidromus than to either Caprimulgus or Setochalcis. ${ }^{4}$ Its diagnosis is as follows:

\section{Genus ANTROSTOMUS Bonaparte.}

Similar to Caprimulgus Linnæus, but interorbital region of frontals narrower; palatines of very different shape, the distance from their posterior border to the posterior ends of the foramina in their middle portion much greater, nearly double, and these openings much smaller; the inflated posterior parts of the palatines themselves produced on each side considerably farther back than at the median line, thus more drawn to a point, and the postero-external outline of palatines laterally much less convex, in fact almost straight; vomer broader, and pointed, instead of bluntly rounded, at its anterior end; maxillo-palatines longer and relatively narrower, more strapshaped, less shoe-shaped or hook-like; the palatal opening between the halves of the premaxillary smaller and more regularly oval; rictal bristles with long and conspicuous lateral filaments; tail more rounded; and pterylosis different. ${ }^{5}$

All the other American goatsuckers commonly referred to the genus Antrostomus, excluding those recently removed to other genera by Mr. Robert Ridgway, ${ }^{6}$ agree, so far as I have been able to examine them, very closely in external generic characters, but I have seen the skull of only "Antrostomus" vociferus, from which I have drawn the cranial characters for this group. Since there are external generic differences distinguishing all these species from both Caprimulgus and Antrostomus (carolinensis), and likewise so many and such excellent cranial characters in "Antrostomus" vociferus (see

${ }^{1}$ Caprimulgus Linnæus, Syst. Nat., ed. 10, vol. 1, 1758, p. 193 (type, by tautonymy, Caprimulgus europaeus Linnæus).

$\approx$ Gray, List Gen. Birds, 1840, p. 7 .

¿ Bonaparte, Geog, and Comp. List Birds Europe and North Amer., 1838, p. 8 .

S See p. 11.

5 Sec Clark, Auk, vol. 18, 1901, pp. 168-169.

- Ridgway, Proc. Biol. Soe. Wash., vol. 25, May 4, 1912, pp. 98-99. 
pl. 2, fig. 2), it seems necessary to separate all these American species under the name-

\section{SETOCHALCIS, ${ }^{1}$ new genus.}

Somewhat resembling Antrostomus Bonaparte (as restricted above), but interorbital region of frontals much wider; palatines with inflated posterior portion smaller, the postero-external angles more sharply pointed and little if any extended backward beyond the median part of the palatines; vomer somewhat more sharply pointed; maxillo-palatines smaller, shorter, less sharply pointed and much more widely separated; the oval palatal opening between the halves of the premaxillary more elongate; pterygoids not so far separated from the basisphenoid, resting almost against it for the anterior half of their length; rictal bristles without lateral filaments; second primary (counting from the outermost) longest, the third but little shorter, the first considerably shorter than the third and about equal to the fourth (in Antrostomus the second primary is the longest, but the third is decidedly shorter, the first still a little shorter, but very much longer than the fourth); three primaries sinuate on their outer webs, instead of two as in Antrostomus; wing relatively shorter; and pterylosis different. ${ }^{2}$

Superficially similar to Caprimulgus Linnæus, but palatines very differently shaped, the distance from their posterior border to the posterior ends of the foramina in their middle portion much greater, and these openings much smaller; the postero-external angles of palatines much more sharply pointed, and the postero-external outline laterally much less convex, indeed nearly straight; vomer broader, and pointed, instead of bluntly rounded, at its anterior end; maxillo-palatines more oval or strap-like, not so shoe-shaped or hook-like, and much more widely separated; the palatal opening between the halves of the premaxillary smaller, narrower, more oval (less ovate); pterygoids not so far separated from the basisphenoid, but resting almost against it for the anterior half of their length; second primary (counting from the outermost) longest, the third only a little less, the first considerably shorter than the third and about equal to the fourth (in Caprimulgus ${ }^{3}$ the second primary is also the longest, but the third is decidedly shorter, the first still a little shorter or equal, but very much longer than the fourth); three primaries sinuate on their outer webs, instead of two as in Caprimulgus; tail more rounded; wing relatively shorter.

The type of this genus is Caprimulgus vociferus Wilson.

1 Ełs, otrtós, tinea; zadk's, avis nocturna.

2 See Clark, Auk, vol. 18, 1901, pp. 168-169.

3 It should be remembcred that all these comparisons with Caprimulgus refer to Caprimulgus europaeus only. See p. 10. 
Its geographical range is as follows: South America, Central America, the West Indies, and North America excepting the northern and central western portions.

The species and subspecies at present referred to this genus, of most of which the writer has examined skins, are as follows:

Setochalcis sericocaudata (Cassin.) ${ }^{1}$

Setochalcis mufa mufa (Boddaert).

Setochalcis rufa otiosa (Bangs).

Setochatcis saturata (Salvin).

Setochalcis badia (Bangs and Peck). ${ }^{2}$

Setochalcis salvini (Hartert). ${ }^{3}$

Setochalcis cubanensis (Lawrence).

Setochalcis vocifera vocifera (Wilson).

Setochalcis vocifera arizonae (Brewster)."

Setochalcis vocifera macromystax (Wagler). ${ }^{5}$

Setochalcis vocifera oaxacae (Nelson). ${ }^{6}$

Setochalcis vocifera chiapensis (Nelson).

Setochalcis ridgwayi ridgwayi (Nelson).

Setochalcis ridgwayi goldmani (Nelson). ${ }^{7}$

Phylogeny.-The genus Chordeiles, like the American branch of the family Caprimulgidae, is of South American origin. This is evident from the facts that two of its three species, Chordeiles acutipennis and $C$ hordeiles rupestris, are still permanently resident there; that the forms of Chordeiles acutipennis which live in Central America and Mexico are more or less migratory; and, futhermore, that Chordeiles virginianus, the remaining species, though at present entirely West Indian and North American in its distribution during the breeding season, returns entirely to South America to pass the winter.

It seems probable that the present genus with its two nearest generic allies, Nannochordeiles and Nyctiprogne, had a common immediate ancestor; though, perhaps, Nannochordeiles, which is really

\footnotetext{
1 This is the original spelling of the specific name.

This is apparently the same as the subsequent Antrostomus nelsoni Ridgway (Proc. Biol. Soc, Wash., vol. 25, May 4, 1912, p. 90).

3 This is the same as Antrostomus notabilis Neison, of later date.

4 This is a perfectly good race, differing from Setochalcis vocifera macromystax of the eastern, central, and south central parts of Mexico, from southern Coahuila to Guerrero, in lighter and more brownish coloration both above and below. It was originally described by Mr. William Brewster as Antrostomus vociferus arizonae (Bull. Nuttall Orn. Club, vol. 6, 1881, p. 69) from the Chiricahua Mountains in southern Arizona. It ranges north to southern Arizona and central western Texas; west to Arizona; south to Jalisco, Mexico; east to Durango, Mexico, and central western Texas.

5 This is Caprimulgus macromystax Wagler (Isis, 1831, col. 533), which has no more specific locality than "Mexico." Since, in view of the several subspecific forms since described, it is desirabie to have a more definite type-locality, we designate as such Mount Orizaba, Puebla, Mexico.

- Still known from oniy the type specimen, a female, and if distinct from Setochalcis vocifera macromystax Wagier, is certainly but a subspecics of Setochalcis vocifera.

7 Clearly not more than subspecifically different from Setochalcis ridgwayi.
} 
a small, somewhat modified Chordeiles, is a more direct offspring of the latter group.

The real relationship and therefore the origin of the three species of Chordeiles is a problem of some difficulty. It seems probable, however, that Chordeiles virginianus, to have become, in structure, pattern of coloration, and color so well differentiated specifically from both Chordeiles acutipennis and Chordeiles rupestris; to have established itself entirely outside of South America; to have spread over and permanently occupied as a summer home so large an area; and to have become modified into so many geographic races, notwithstanding the very brief period in each year during which the modifying influences could be operative, must be a relatively ancient species. On the other hand, Chordeiles acutipennis, less stable than Chordeiles virginianus in structural characters, less dispersed into territory where it is migratory, modified into fewer subspecific forms, and these less strongly differentiated from the parent stock, and still largely resident in South America, seems to be of more recent origin. But Chordeiles rupestris, which is very different from Chordeiles acutipennis in pattern of coloration and in structure, and which occupies approximately the same area in South America, probably, therefore, developed simultaneously from the same ancestor. Furthermore, the close superficial resemblance in color and markings which Chordeiles acutipennis acutipennis from northern South America bears to Chordeiles virginianus minor from Jamaica and Cuba is at least suggestive, if not significant. Thus we naturally arrive at the hypothesis that all three species of Chordeiles were derived from a common ancestor, probably resembling Chordeiles virginianus in structure and Chordeiles acutipennis in coloration, but now extinct, from which Chordeiles virginianus first became differentiated, and afterwards both Chordeiles acutipennis and Chordeiles rupestris, the latter so greatly specialized, as it is now seen to be in color pattern, by some unknown agency, possibly individual variation and subsequent fortuitous, temporary segregation. The only region where the two species, Chordeiles virginianus and Chordeiles acutipennis, occupy a common breeding area is in the southwestern United States and extreme northern Mexico. Here the former seems to have immigrated first, and from the north and east; while afterwards Chordeiles acutipennis, then a perfectly distinct species, extended its range northward from southern Mexico until it overlapped that of Chordeiles virginianus, and it seems to be still pushing northward.

Sequence of forms.-An ideal linear sequence of species and subspecies, which shall show their proper phylogenetic relationship, is, however, desirable, probably out of the question in a complicated group like the genus Chordeiles. As some such arrangement is, of 
course, necessary for the sake of convenience, and as it is more satisfactory for a list or technical treatise to begin the catalogue of subspecies under each species with the "typical," or rather the first-described race, the name of which the species as a whole bears, the writer has tried to arrange the subspecific forms in as natural an order as is possible under these circumstances, and this sequence he has followed in the detailed treatment of the forms of the genus.

A linear arrangement more satisfactory from the standpoint of relationship may, of course, be obtained by disregarding the purely arbitrary placing of the first-described form of a species at the head of the list of subspecies. Such a list, with due regard for the phylogeny and present-day affinities of both species and subspecies; and one which seems to the writer to express, as eloquently as a mere list can, their known or assumed reiationships, is as follows:

Chordeiles virginianus minor.

Chordeiles virginianus vicinus.

Chordeiles virginianus chapmani.

Chordeiles virginianus aserriensis.

Chordeiles virginianus virginianus.

Chordeiles virginianus hesperis.

Chordeiles virginianus sennetti.

Chordeiles virginianus howelli.

Chordeiles virginianus henryi.

Chordeiles acutipennis acutipennis.

Chordeiles acutipennis exilis.

Chordeiles acutipennis micromeris.

Chordeiles acutipennis texensis.

Chordeiles acutipennis inferior.

Chordeiles rupestris rupestris.

Chordeiles mupestris xyostictus.

Chordeiles rupestris a aleucus.

The necessity of beginning in each species with the oldest or lowest form brings into juxtaposition, in a linear arrangement, the lowest or oldest form of any one species with the highest or most recent form of the preceding species, but there seems to be no better way. In the above list this is most noticeable with regard to Chordeiles virginianus and Chordeiles acutipennis, for, of the races of the former, Chordeiles virginianus minor is undoubtedly the one most closely allied to Chordeiles acutipennis acutipennis, though of necessity placed farthest from it serially.

The sequence of subspecies under each species is also difficult to express in a single linear list, owing to the fact that some races are about equally related to two or three others. Thus in the case of 
Chordeiles virginianus the subspecies are properly placed in their phylogenetic order as far as the fourth, for Chordeiles virginianus aserriensis is surely a pale form derived from Chordeiles virginianus chapmani. But Chordeiles virginianus virginianus is without doubt also an offshoot from Chordeiles virginianus chapmani, and subspecifically not very closely allied to Chordeites virginianus aserriensis. The rest follow in their presumed natural order.

In Chordeiles acutipennis a practically natural order is possible, the only races which require comment in this connection being Chordeiles acutipennis acutipennis and Chordeiles acutipennis exilis. Were the linear sequence to be strictly geographical, that of the first three races of Chordeiles acutipennis would be Chordeiles a. exilis, ${ }^{1}$ Chordeiles a. acutipennis, Chordeiles a. micromeris; for the first is geographically isolated from the Central American form not only by a hiatus in the breeding range but by the interpolation of Chordeiles acutipennis acutipennis. This race, Chordeiles acutipennis exilis, ${ }^{1}$ is, however, in some characters a cleparture from Chordeiles acutipennis acutipennis in the direction of Chordeiles acutipennis micromeris, though not exactly intermediate, and is probably the result of environmental conditions somewhat similar to those of the last-mentioned form.

In the case of Chordeiles rupestris, the material is so limited that only a suggestive opinion is possible. If all the characters of Chordeiles rupestris xyostictus ${ }^{2}$ and Chordeiles rupestris aaleucus, ${ }^{3}$ particularly of the latter, prove constant in a larger series, the former is probably the one most closely allied to Chordeiles mupestris mpestris, since it differs only in colors, whereas Chordeiles rupestris zaleucus differs also in pattern of coloration.

Species and subspecies.-There seem to be only three specific types referable to the genus Chordeiles, namely, virginianus, acutipennis, and rupestris; but these are so trenchantly different from each other both structurally and in pattern of coloration that there can be no question of their entire distinctness. All the other forms are clearly subspecies. The 17 forms here recognized are distributed as follows: Chordeiles virginianus, with 9 races; Chordeiles acutipennis, with 5; and $C$ hordeiles rupestris, with 3 . For convenience of reference a list of all these, with their type localities, is added here: 


\begin{tabular}{|c|c|}
\hline Name. & Type-locality. \\
\hline Chordeiles virginianus virginianus.. & Eastern Virginia. \\
\hline Chordeiles virginianus hesperis..... & $\begin{array}{l}\text { Bear Lake, San Bernardino Mountains, southern } \\
\text { California. }\end{array}$ \\
\hline Chordeiles virginianus sennetti.... & $\begin{array}{l}50 \text { miles west of the Pembina Mountains, central } \\
\text { northern North Dakota. }\end{array}$ \\
\hline Chordeiles virginianus howelli $1 . .$. & Lipscomb, northwestern Texas. \\
\hline Chordeiles virginianus henryi....... & Fort Webster, southern New Mexico. \\
\hline Chordeiles virginianus aserriensis ${ }^{2}$.............. & Valley of Aserri River, near San José, Costa Rica. \\
\hline Chordeiles virginianus chapmani......... & Gainesvilie, northern Florida. \\
\hline Chordeiles virginianus vicinus......... & Long Island, Bahama Islands. \\
\hline Chordeiles virginianus minor......... & Northern coast of Cuba. \\
\hline Chordeiles acutipennis acutipennis.. & Cayenne, French Guiana. \\
\hline Chordeiles acutipennis exilis $8 . . . . . .$. & Northern Chile. \\
\hline Chordeiles acutipennis micromeris $4 . .$. & Xbac, northern Yucatan, Mexico. \\
\hline Cliordeiles acutipennis texensis.... & $\begin{array}{l}\text { Ringgold Barracks, near Rio Grande City, southern } \\
\text { Texas. }\end{array}$ \\
\hline Chordeiles acutipennis inferior ${ }^{5}$.. & Triunfo, southern Lower California, Mexico. \\
\hline Chordeiles rupestris rupestris...... & Rocky islands of the Rio Negro, northern Brazil. \\
\hline Chordeiles rupestris xyostictus ${ }^{6} . .$. & Bogota, Colombia. \\
\hline Chordeiles rupestris zaleucus $7 . . . . . . .$. & Pebas, northern Peru. \\
\hline
\end{tabular}

${ }^{1}$ New subspecies; see p. 57.

2 See p. 71 .

3 See p. 98.

4 New subspecies; see p. 100.
- New subspecies; see p. 109.

- New subspecies; see p. 116 .

${ }^{3}$ New subspecies; see p. 118.

Recognition of subspecies.-All but two of the forms here treated as subspecies are found to intergrade with some one or even several other forms, either by gradual mergence across an intermediate geographic area, or if isolated on islands or elsewhere, then by individual variation, and in the first case not infrequently both geographically and individually, so that each species is made up of a complete chain of connected races. The two exceptions mentioned are Chordeiles rupestris xyostictus ${ }^{8}$ and Chordeiles rupestris zaleucus, ${ }^{9}$ both being little-known birds of probably limited distribution, the characters of which are such as reasonably presuppose their subspecific, rather than specific, relationship, for which reason we have here assigned them such a rank.

The problem of the number of subspecies to be recognized is, as in the case of similar wide ranging and plastic animals, a somewhat difficult one, particularly in Chordeiles virginianus and Chordeiles acutipennis. The great individual variation seriously complicates the situation, for however few may be the subspecific divisions of particularly these two species, such subspecies will more or less overlap those of one or more others, hence the characters can in no case be more than average. There are, notwithstanding this excessive and troublesome individual variation, well-marked geographic 
differences which, upon examination of proper series, are apparent at a glance; and there are also other geographic variations, not very evident, except by careful study, and which may or may not have special significance according to the attitude of the investigator. The nominal designation of these small and apparently more or less ephemeral differences may, it seems to me, properly be left until future time and study shall make such a course adrantageous. For the present purpose, therefore, the writer has contented himself with recognizing in nomenclature such differences of size, pattern, and color as appear to maintain during the breeding season a fair average differentiation and uniformity over an isolated or reasonably different or extensive geographic area. The results, while they thus bring into evidence probably all the significant geographic variations of the several species, at least in so far as the available material warrants, are at the same time not excessive subdivision. Fewer subspecies would obscure interesting geographic variations, with little or no gain in the ease of identification of given specimens; more would seem, from the outlook of our present material: superfluous and inadvisable.

Identification of specimens.-The naming of subspecies is most important in that it brings into prominence the facts of geographic distribution and evolution and provides convenient handles for their use. In the case of migratory birds it furnishes a means, often of great value, sometimes indispensable, of tracing their wanderings.

Given any certain number of races, therefore, of a Chordeiles or species of any other genus, with a mass of undetermined material, it naturally follows that proper identification must precede any use of the facts which such material exhibits. This, however, in difficult groups, like Chordeiles, is often a matter of considerable difficulty, and for satisfactory results requires a good series of authentic specimens for comparison, coupled with a thorough knowledge of differential characters and variations. In the present genus, so great and so complicated is the variation of individuals, sex, and age, that it is absolutely necessary to make comparisons with specimens of the same sex and age and with typical series. On this account very full comparisons are, in the following pages, made under the head of each subspecies. As is always the case with subspecies, the differences separating which are only average, there are specimens in nearly all the races of Chordeiles, which individually are not separable from certain individuals of some other race. With breeding birds of this kind identification is in most cases comparatively easy, for if their respective localities are within the known range of any subspecies they are, of course, identifiable as individual variants of such 
subspecies. But birds from intermediate areas require more careful examination, and often a series from a locality is necessary for their proper allocation. Since, however, the certain breeding period of Chordeiles is comparatively so short, most of the specimens collected are either migrants or not surely breeding birds, and their subspecific determination becomes often a matter of great difficulty, and sometimes of more or less uncertainty as well.

For obvious reasons an attempt has been made to name every specimen handled in the present investigation, and the results are contained in the lists of specimens under each subspecies. With such a large proportion of specimens of unknown breeding origin, in a group which presents so many puzzling and overlapping variations as do the subspecies of Chordeiles virginianus and Chordeiles acutipennis, it is too much to hope that I have correctly placed every single individual of the large number that I have examined; but I have carefully scrutinized and compared every one, so that the final determination as printed represents, in each individual case, the best opinion I can offer with the means at my present disposal. Some doubtful specimens have been identified and reidentified during the progress of the work as many as six or eight times, not always, it must be admitted, with the same result! In instances such as those mentioned above, where a given variant specimen can be matched by individuals belonging to two or even more races, the specimen has been assigned to that form by the average subspecific characters of which it is most closely approached; and, in determining this, both the average of single characters among individuals of the same form, and an average of all the differential characters of the given subspecies are taken into consideration. This seems to be the only logical way to treat such cases, and by it we probably much more closely approximate the truth than by any other method.

Variation.-The species of this genus have a wide range of all kinds of variation excepting seasonal, which is at a minimum, due partly to the comparatively little abrasion to which the plumage is subject; partly to the great similarity of freshly molted birds to those in worn plumage, for there are, on the fresh feathers, no differently colored tips or edges to wear off; and partly, in the case of a semiannual molt, to the sameness of successive adult plumages.

Individual variation is often so great as seriously to complicate the problem of geographic forms, as well as to render difficult the identification of specimens. Furthermore it is just as great in the sedentary as in the migrant forms. This is, however, fully treated under the various species and subspecies.

Sexual differences are about equally great in all the species. In Chordeiles acutipennis and Chordeiles virginianus they are of very 
similar kind, and are mostly differences of color; while in Chordeiles rupestres they consist more in the pattern of coloration.

The variation due to age is likewise about the same in Chordeiles virginianus and Chordeiles acutipennis, and is so great that there is no difficulty at all in distinguishing immature from adult birds. The immature plumages of Chordeiles rupestris appear to be unknown, but their relative differences are probably much the same as those of the other species of the genus.

Geographic variation is not so great as in many other birds of even less but otherwise similar geographic range but of greater plasticity. This variation has been kept down in part, doubtless, by the extensive migration of the northern forms; but it probably can not be fully accounted for in such a way, since the species least or not at all migratory, Chordeiles acutipennis and Chordeiles rupestris, are seen to be, if anything, less variable than the highly migratory Chordeiles virginianus. Apparently such a condition of limited geographic variation is induced also by the excessive individual variation in species of this genus; by their inherent smaller degree of plasticity; as well as by the phylogenetic age of the species, as compared with those of other genera. The last may also be a determining factor in the species of Chordeiles, as compared with each other; and if Chordeiles acutipennis and Chordeiles mupestris are of more recent evolution than Chordeiles virginianus, as seems probable, this may be, in geographic variation, an offset to their more sedentary habits.

General habits.-The nighthawks of this genus are birds of the open country. Being strong of wing, they are of easy though powerful flight, and spend much time in the air, where they obtain most of their insect food, which their great mouths admirably fit them to scoop in while on the wing. Their feet are weak, and not well adapted to perching in the ordinary way; so the birds rarely alight high up in trees, but crouch on the ground or other flat surface, on posts, fence-rails, rocks, prostrate trees, or low branches; and, when on a branch, $\log$ or fence-rail, sit almost invariably lengthwise of the perch.

These nighthawks build no nest, but deposit their two well-mottled eggs on the ground or similar places. The young are practically helpless for some time after birth.

Unfortunately these birds furnish a good mark for the hunter, and often on this account fall to the gun of the sportsman or pot-hunter. They deserve a much better fate, for they are beneficial birds, living almost entirely, if not exclusively, on insects.

History. - The earliest account of any species of this genus is by Catesby, ${ }^{1}$ who in 1743 described Chordeiles virginianus as the

${ }^{1}$ Nat. Hist. Carolina, Florida, and Bahama Islands, rol. 2, Appendix, 1743, p. 16, pl. 16. 
"Whippoorwill, Caprimulgus minor Americanus." The South American Chordeiles acutipennis was first brought to notice by Buffon, ${ }^{1}$ who gave, under the name "L'Engoulerent acutipenne de la Guyane," a description and a brief note on its habits. Both these species, when subsequently given a binomal name, were referred to the genus Caprimulgus Linnæus, as was also a third species described later by Spix $^{2}$ as Caprimulgus rupestris. Swainson was the first author to recognize their structural differences from Caprimulgus, and first separated the nighthawlis generically as Chordeiles. ${ }^{3}$ Another species, described as Chordeiles pusillus, ${ }^{4}$ has since been made the type of a new genus Nannochordeiles by Dr. E. Hartert. ${ }^{5}$ Further species which have been at one time or another by some authors referred to Chordeiles, but which all belong in other genera, are Siphonorhis americanus, Nyctiprogne leucopyga, Nytipolus himundinaceus, ${ }^{6}$ Lurocalis semitorquatus, Lurocalis nattereri, and Nyctibius leucopterus.

Nomenclature.-Swainson's name for this generic group, Chordeiles, first proposed by him in $1832,{ }^{7}$ is by several years the earliest appellation, and is of undoubted application, since it is monotypic, and has for its type by original designation "Chordeiles virginianus (Caprimulgus americanus Wils.)," which is, of course, none other than Caprimulgus virginianus Gmelin. A subsequent generic name is Microrhynchus Lesson, ${ }^{8}$ type by monotypy, Caprimulgus exilis Lesson; but besides being 11 years antedated by Chordeiles Swainson is, furthermore, untenable under any circumstances by reason of Microrhynchus Dejean, ${ }^{9}$ a genus of Coleoptera, and Microrhynchus Bell, ${ }^{10}$ a genus of Crustacea. In 1857 Bonaparte, either unaware of Microrhynchus Lesson, or considering it unusable, proposed Ramphaoratus ${ }^{11}$ in the following fashion:

9. Ramphaoratus, $B p$.

35. truncatus, $B p$. Mus. $B r$.

(caberculatus? Jardin.

36. exilis, Less.

pruinosus, Tschudi).

From this it is evident that he intended to include two species: the first an undescribed form to be based on specimens in the British Museum, and which he regards as probably or possibly identical with

\footnotetext{
1 Hist. Nat. des Oiseaux, orig. ed., vol. 1779, pp. 547-548.

2 Avium Spec. Nov. Bras., vol. 2, 1825, p. 2, pl. 2.

s Fauna Bor.-Amer., vol, 2, 1831 (1832), p. 496.

4 Gould, Proc. Zool. Soc. Lond., 1861, p. 182.

'Ibls, Juls, 1896, p. 374.

${ }^{6}$ See p. 97.

" Fauna Bor.-Amer., rol. 2, 1831 (1832), p. 496.

${ }^{8}$ L'Echo du Monde Savant, July 16, 1843, col. 109.

- Catalogue des Coleopteres, 1821, p. 98 (Megerle MS.).

20 Proc. Zool. Soc. Lond., 1835 , p. 88.

${ }^{21}$ Rivista Contemporanea, vol. 9, February, 1857, p. 215 (p. 9 of reprint).
} 
"caberculatus" Jardine, this undoubtedly a misprint for [Caprimulgus] labeculatus Jardine, a synonym of Chordeiles acutipennis; and the second species, Caprimulgus exilis Lesson, with which he synonymizes Caprimulgus pruinosus Tschudi. Since the Ramphaoratus truncatus of Bonaparte is a nomen nudum, it leaves Caprimulgus exitis Lesson as the virtually monotypic type of Ramphaoratus.

The generic term Chordeiles has, like so many others, suffered at the hands of emenders, who, in seeking to "improve" the name, have in some cases made it worse. This is an excellent example of the impossibility of formulating any satisfactory rule for the emendation of names, because, as in the present instance, there are often several different ways of spelling the same word, by varying the terminations, all of which are orthographically and classically correct, and merely a matter of preference. The best course, therefore, from the standpoint of either reason or convenience, is to adhere to the original spelling of generic names, even though in some instances this be, from a classical point of view, evidently wrong. The name Chordeiles has been spelled in at least five different ways, including the original, and under the International Code of Nomenclature most of these would be regarded, so far as their form is concerned, as tenable generic terms. Mr. G. R. Gray in $1840^{1}$ first changed the name to Chordeitus, designating the type, as in the original Chordeiles, Caprimulgus virginianus Gmelin. Next Tschudi in $1846^{2}$ spelled it Chordiles, and included only " $C h$ [ordiles]. semitorquatus Cab.," which is, of course, the same as Caprimulgus exilis Lesson. In $1847^{3}$ Cabanis emended it to Chordediles, and the type of this is, of course, the same as that of the original Chordeiles. In $1869^{4} \mathrm{Mr}$. G. R. Gray credits Cabanis with the orthography "Chordedilus," supposedly used in 1861; but, after careful search, I have not been able to locate the reference. There may be still other spellings of Chordeiles buried in the literature, but I have been unable to discover them.

The word Chordeiles is derived from the Greek $\chi 0 p \delta \%$, a string (of a lyre or other musical instrument), and $\delta \varepsilon \hat{\imath} \lambda \eta$, evening, or twilight; and the longer forms of the word, Chordediles and Chordedilus, are better, orthographically, than the contraction Chordeiles. This, however, does not, of course, concern us in the scientific use of the name.

Literature.-Few extended papers on this genus have appeared, and most of its literature consists of scattered notes on the species, often in connection with birds of other genera and families, in

1 List Genera Birds, 1840 , p. 7 .

2 Fauna Peruana, Ornith., 1846, p. 21.

' [WViegmann's] Archiv fiir Naturg., vol. 13, pt. 1, November, 1847, p. 346.

- Hand-List Gen. Spec. Birds, vol. 1, 1869, p. 61. 
faunal papers or books on birds of large groups or extended geographic areas. The two most valuable articles on the genus as a whole are, of course, Dr. Hartert's account in the Catalogue of Birds in the British Museum, and in the Tierreich. Full citation of these and the other more important papers dealing wholly or in part with the birds of the present genus are given in the following chronological list, from which, however, are omitted references to several of the original descriptions, since these can be found in the synonymy of the various forms of the genus:

Sprx, J. B.-Avium Species Novae, quas in itinere per Brasiliam annis 18171820 colleg. et descripsit; vol. 2, 1825, p. 2, pl. 2.

Cassin, John.-Illustrations of the Birds of California, Texas, Oregon, British and Russian America; 1855, pp. 237-239.

Burmerster, C. H. C.-Systematische Uebersicht der Thiere Brasiliens, vol. 2, 1856, pp. 393-397.

BAIRD, S. F.-Reports of Explorations and Surreys to Ascertain the most Practicable and Economical Route for a Railroad from the Mississippi River to the Pacific Ocean, vol. 9, 1858, pp. 150-155.

SClater, P. L.-Notes upon the American Caprimulgidæ. Subfamily III. Caprimulginæ. Proceedings of the Zoological Society of London, 1866, pp. 131-135.

Pelzetn, August von.-Zur Ornithologie Brasiliens, 1 Abth., 1868, p. 14.

BaIrd, S. F.; BREwer, T. M.; and Ridgway, R.-History of North American Birds; Land Birds, vol. 2, 1874, pp. 399-408.

Taczanowski, Ladislas.-Ornithologie du Pérou, vol. 1, 1884, pp. 210-215.

Coues, EliotT.-Key to North American Birds, second edition, 1884, pp. 453455.

Shufeldt, R. W.-Contribution to the Comparative Osteology of the Trochiliclæ, Caprimulgidæ, and Cypselidæ. Proceedings of the Zoological Society of London, 18\$5, pp. 8\$6-915, pls. 58-61.

Ridgway, Robert.-Manual of North American Birds, 1857, pp. 297, 300-301.

Coues, Elliott.-New Forms of North American Chordiles. Auk, vol. 5, January. 18ss, p. 37.

Hartert, Ernst.-Chordeiles. Catalogue of the Birds in the British Museum, vol. 16, 1892, pp. 521, 609-618.

Salvin, Osbert; and Godman, F. D.-Biologia Centrali-Americana ; Aves, vol. 2, November, 1894, pp. 395-398.

Bendire, Charles.-Life Histories of North American Birds, from the Parrots to the Grackles, with Special Reference to their Breeding Habits and Eggs, 1S95, pp. 163-174.

Hartert, Ernst.-Das Tielreich. I. Lieferung: Podargidae, Caprimulgidae, Ind Macropterygidae, 1897, pp. 18-21.

Beddard, F. E.-The Structure and Classification of Birds, 1898, pp. 234-242.

Coues, Elliotr.-Key to North American Birds, fifth edition, vol. 2, 1903, pp. 563. $568-570$.

Hellmayr, C. E.-The Birds of the Rio Madeira. Novitates Zoologicae, vol. 1910, p. 378.

Key to species and subspecies.-The following key to the forms of Chordeiles is confessedly but little more than a comparative statement of characters, although purposely rather full; and while it may in some cases suffice for the identification of a bird in hand, its main 
purpose is, of course, to aid in comparison of specimens. So difficult, in fact, are the birds of this genus, that, owing to the wide range of individual and other variation in them all, it is quite out of the question to prepare a satisfactory key for use without recourse to properly determined material. The present attempt at a key is based entirely on adults, since the juveniles are not represented completely enough in our series to be included. This key is, of course, dichotomous, and first sets off the forms of each species, then the sexes of each.

KEY TO THE SPECIES AND SUBSPECIES OF CHORDEILES, BASED ON ADULTS.

$u^{2}$. Abdomen and crissum pure white; jugulum pale grayish; basal portion of tail, secondaries, and of inner primaries largely white; 3 outer primaries without white or buffy spots; axillars and part of under wing-coverts pure white. (Chordeiles rupestris.)

$b^{\mathbf{1}}$. Larger; fourth primary (counting from outermost) without a white spot; tail with much less brown at base and elsewhere; dark brown tips of rectrices not mottled with paler. (MLalcs.)

$c^{1}$. Upjer parts darkel.

Chordeiles rupestris zaleucus.

$c^{2}$. Upper parts lightel.

$d^{1}$. Somewhat smaller; upper surface much darker, the deep brown mark-

ings dacidedly larger; breast much less hearily spotted, sometimes even nearly immaculate Chordeiles rupestris rupestris.

$d^{2}$. Somewhat larger; upper surface much lighter, the deep brown markings decidedly smaller; breast much more hearily spotted.

Chordeilcs rupestris xyostictus.

$b^{2}$. Smaller; fourth primary with usually a spot of white; tail with more brown at base and elsewhere; dark brown tips of rectrices mottled with paler. (F'cmales.)

$c^{2}$. More grayish above; white spot on inner vane of fourth primary very large and reaching shaft; inner webs of rectrices with large dark brown spots or broad bar's_._._._._._._Chordciles rupestris zaleucus.

$c^{2}$. More ochraceous or buffy above; white spot on inner vane of fourth primary absent or very small and not reaching shaft.

$d^{1}$. Larger; upper surface lighter, less hearily marked with dark brown; breast more heavily spotted_._..._-_Chordeiles rupestris xyostictus.

$d^{2}$. Smaller; upper surface darker, more hearily marked with dark brown; breast less hearily spotted_-_-_Chordeiles rupestris rupestris.

$a^{2}$ Abdomen and crissum barred with blackish or brown; jugulum dark brown or blackislı; basal portion of tail, secondaries, and of inner primaries not nearly all white, but mostly brown; 3 onter primaries with a large white or buffy spot; axillars and all of under wing-coverts heavily barred with dark brown or blackish.

$b^{1}$. White or buffy patch on usually 4 outer primaries situated between the tips of the fifth and eighth primaries (counting from the outermost); primary coverts and outer webs of primaries and secondaries with conspicuous spots or bars of buff or ochraceous; first (outermost) primary usually shorter than second. (Chordeiles acutipennis.)

$c^{1}$. Larger; wing speculum larger and white; a white subterminal bar on tail; throat-patch white. (Mlales.) 
$d^{2}$. Size greater (wing averaging more than $180 \mathrm{~mm}$.).

Chordeiles aeutipennis texensis.

$d^{2}$. Size smaller (wing averaging less than $178 \mathrm{~mm}$.).

$e^{1}$. Lower parts darker, more heavily barred.

Chordeiles acutipennis acutipennis.

$e^{2}$. Lower parts lighter, less heavily barred.

$f^{2}$. Smaller (wing areraging under $160 \mathrm{~mm}$.) ; pale bars on under side of tail more whitish; light bars on posterior lower parts averaging wider

Chordeiles acutipennis exilis.

$f$. Larger (wing averaging over $165 \mathrm{~mm}$.) ; pale bars on under side of tail more buffy or ochraceous; light bars on posterior lower parts averaging narrower.

$g^{1}$. Light bars on tail broader; size averaging larger.

Chordeiles acutipennis inferior.

$g^{2}$. Light bars on tail narrower; size averaging smaller.

Chordeiles acutipennis mieromeris.

$c^{3}$. Smaller; wing speculum smaller, and buff or largely so; no white sub-

terminal bar on tail; throat-patch buff or ochraceous. (Females.)

$d^{1}$. Large (wing usually more than $174 \mathrm{~mm}$., averaging over $170 \mathrm{~mm}$.).

Chordeiles acutipennis texensis.

$d^{2}$. Small (wing usually less than $168 \mathrm{~mm}$., averaging under $170 \mathrm{~mm}$.).

$e^{1}$. Above darker; lower surface darker and posteriorly more heavily barred; size smaller._-_-_-_._Chordeiles acutipennis acutipennis.

$e^{2}$. Below paler; lower surface lighter and less heavily barred; size greater.

$f^{1}$. Larger (wing areraging more than $166 \mathrm{~mm}$ ) ; light bars on tail broader Chordeiles acutipcnnis inferior.

$f^{2}$. Smaller (wiug averaging less than $163 \mathrm{~mm}$.) ; light bars on tail narrower.

$g^{1}$. Posterior lower parts darker; size greater.

Chordeiles acutipennis micromeris.

$g^{2}$. Posterior lower parts lighter; size smaller.

Chordeiles acutipennis exilis.

$b^{2}$. White or buffy patch on usually 5 outer primaries situated between the tips of the seventh and tenth primaries; primary coverts and outer webs of primaries and of secondaries without spots or bars of buff or ochraceous, or with at most faint markiugs; first primary usually longer than second. (Chordeiles virginianus.)

$c^{2}$. Larger; alar speculum larger, and plain white without dusky markings; a white subterminal bar on tail; gular crescent pure white; lower parts less buffy. (Males.)

$d^{1}$. Light mottlings of upper surface deeply tawny.

$e^{\mathbf{1}}$. Posterior lower parts paler, more buffy or whitish; upper surface lighter; size larger (wing averaging $199.7 \mathrm{~mm}$.).

Chordeiles virginianus henryi.

$e^{2}$. Posterior lower parts darker, more ochraceous or tawny; upper surface darker; size smaller (wing averaging $168 \mathrm{~mm}$.).

Chordeiles virginianus minor.

$d^{2}$ Light mottlings of upper surface ochraceous buff or white.

$e^{1}$. Smaller (wing usually less than $188 \mathrm{~mm}$.).

$f^{1}$. Uiper surface darker, the pale mottlings much less numerous.

Chordciles virginianus chapmani.

$f^{2}$. Upper surface lighter, the pale mottlings much more numerous. 
$g^{1}$. Smaller (wing usually less than $176 \mathrm{~mm}$. ) ; upper parts darker. Chordeiles virginianus vicinus.

$g^{2}$. Larger (wing usually more than $180 \mathrm{~mm}$.) ; upper parts lighter. Chordeiles virginianus aserriensis.

$e^{3}$. Larger (wiug usually more than $192 \mathrm{~mm}$.).

$f^{7}$. Upper surface darker, more b]ackjsh, the light mottliugs much less numerous Chordeiles virginianus virginianus.

$f^{3}$. Upper surface lighter, more brownish, the light mottlings much more numerous.

$g^{1}$. Above darker, the light mottlings less numerous.

Chordeiles virginianus hesperis.

$g^{2}$. Above lighter, the light mottlings mole numerous.

$h^{1}$. Dark brown of upper parts more rufescent, the light mottlings more ochraceous or buffy.

Chordeiles virginianus howelli.

$h^{2}$. Dark brown of upper parts more grayish, the light mottlings more grayish or whitish.

Chordeiles virginianus sennetti.

$c^{2}$. Smaller; alar speculum smaller, and more or less mottled with dusky; white subterminal bar on tail abseut or very narrow; gular crescent buff or ochraceous; lower parts mole buffy or ochraceous. (Females.)

$d^{1}$. Size small, the length of wing usually less than $185 \mathrm{~mm}$., averaging less than $183 \mathrm{~mm}$.

$e^{1}$. Upper surface paler (the ground color lighter and the light markings lighter or much more numerous); lower parts lighter; posterior lower surface less heavily barred.

Chordeiles virginianus aserriensis.

$e^{2}$. Upper surface darker (the ground color darker, and the light markings more deeply colored or much less numerous); lower parts darker; posterior lower surface more heavily barred.

$f$. Lower parts and light markings of upper surface more tawny or ochraceous; size smaller (wing averaging $168.7 \mathrm{~mm}$.).

Chordeiles virginianus minor.

$f^{2}$. Lower parts and light markings of upper surface more grayish or whitish; size larger (wing areraging over $172 \mathrm{~mm}$.).

$g^{1}$. Largel (wing averaging $179.4 \mathrm{~mm}$.) ; posterior lower parts more whitish (less ochraceous); upper surface darker (the ground color more deeply blackish, the light markings less numer-

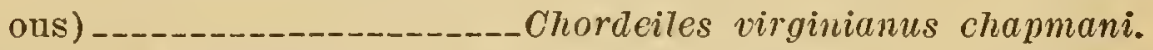

$g^{2}$. Snaller (wing areraging $173.2 \mathrm{~mm}$.) ; posterior lower parts less whitish (more ochraceous); upper surface lighter (the ground color less deeply blackish, the light markings more numerous) -._._._._._._....._Chordeiles virginianus vicinus.

$d^{2}$. Size large, the length of wing usually more than $190 \mathrm{~mm}$., averaging more than $188 \mathrm{~mm}$.

$e^{1}$. Upper surface more brownish, the light markings more ochraceous or tawny; posterior under surface more buffy or ochraceous.

$f^{1}$. Lower parts lighter, posteriorily less ochraceous or buffy (more whitish) ; upper surface lighter__Chordeiles virginianus howelli.

$f^{2}$. Lower parts darker, posteriorly more ochraceous or buffy (less whitish); upper surface darker_._Chordeiles virginianus henryi.

$13732^{\circ}-$ Bull. $86-14-3$ 
$e^{2}$. Upper surface more blackish, the light markings more whitish (less ochraceous or tawny); posterior under surface less buffy or ochraceous (more whitish).

$f^{1}$. Under surface somewhat darker, more tinged with buffy or ochraceous; ground color of upper parts more blackish and the light markings less numerous and somewhat more ochraceous.

Chordeiles virginianus virginianus.

$f^{2}$. Under surface somewhat lighter, less tinged with buffy or ochraceous; ground color of upper parts more brownish and the light markings more numerous and somewhat more whitish (less ochraceous).

$g^{1}$. Dark ground color of upper surface more grayish and somewhat lighter; light markings above more numerous and more grayish or whitish; lower surface slightly lighter.

Chordeiles virginianus sennetti.

$g^{2}$. Dark ground color of upper surface more brownish and somewhat darker; light markings above less numerous and more brownish, buffy or ochraceous; lower surface slightly darker.

Chordeiles virginianls hesperis.

\section{CHORDEILES VIRGINIANUS (Gmelin).}

[Caprimulgus] virginianus Gmes.rN, Syst. Nat., vol. 1, pt. 2, 17S9, p. 1028 (Virginia). ${ }^{1}$

Chars. sp. (adult male).-Interorbital region of skull very broad; longitudinal ridges on the median portion of frontal bones not strongly developed; maxillo-palatines relatively rather broadly subtriangular; vomer very narrow; antero-exterior processes of the palatines moderately slender; pterygoids with a decided exterior angle near the anterior end, whereby the terminal portion is usually more or less parallel with the posterior border of the palatine, and nearly or quite in contact with the latter; first (outermost) primary usually longer than the second; shortest secondary usually falling short of the tips of primary coverts by at least $5 \mathrm{~mm}$.; distance from bend of folded wing to end of shortest secondary nearly always less than from latter point to end of fourth primary (counting from the outermost) ; tips of rectrices rounded ; upper surface black or brownish black, mottled with whitish or buffy; tail dark brown or blackish, irregularly barred with white, gray or buff; wing-quills fuscous, usually the 5 , occasionally the 4 or 6 outer primaries with a large white or rarely buffy spot between the tips of the seventh and tenth primaries (counting from the outermost); primary coverts, also outer webs of primaries and secondaries, either immaculate or with at most faint spots or bars; throat of male white; jugulum and breast dark brown or blackish, spotted with whitish, buff, ochraceous or tawny; remainder of lower surface whitish or buffy, barred with blackish or dark brown; axillars and under wing-coverts dark brown or blackish, barred with whitish or buffy. 
Adult female.-The female differs from the male in being of somewhat smaller size; in having the white wing-patch smaller and usually more or less mottled with dusky; the white subterminal tailbar almost always absent, but if present much narrower; the light throat-crescent cream buff to tawny ochraceous, and often more or less spotted with dusky; lower parts usually more brownish, and posteriorly averaging much more buffy or ochraceous, the crissum rarely if ever pure white. Some of these sexual differences are, however, not so strongly marked in certain of the subspecies as in others.

First autumn plumage.-Although there is some difference in the various races of the species, the first autumn plumage is more or less intermediate between the juvenal and adult plumages. The male in first autumn plumage exhibits the following differences from the adult male: Upper parts with much more numerous pale mottlings, and thus lighter; white speculum smaller; primaries more or less broadly tipped with whitish or buffy; tail without subterminal white band; jugulum and upper breast much vermiculated with whitish, grayish or dull buffy; white throat-patch smaller, less well-defined, somewhat creamy or buffy, and much mottled, usually all over, with dusky. The female in first autumn plumage is similar to the adult of the same sex, but has the upper parts much more mottled with lighter; the upper breast and jugulum more vermiculated with paler; the buff throat-patch much more heavily marked with dusky, sometimes almost obliterated. In this condition the female is much like the male of the first autumn, but the throat is usually more deeply buff and more heavily spotted with dusky.

Juvenal plumage.-In this stage, which immediately precedes the first autumn plumage and succeeds the natal or nestling plumage, and which the bird wears for apparently only a short period, both male and female are usually much lighter above than in the adult plumage or that of the first autumn, the ground color being paler and the light mottlings prevailing; the lower surface has its dark areas also paler, the barring on breast more vermiculate and narrower; the bars on the rest of the lower surface lighter and less distinct; the throat-patch not very strongly indicated, and buff or ochraceous buff.

Natal plumage.-Upper parts grayish or buffy white, everywhere with coarse mouse gray, drab gray, or clove brown mottling; or fawn color with Prout's brown markings; below, white or cream white, mottled on throat and jugulum with gray or grayish brown; or pale fawn color, mottled on throat and jugulum with Prout's brown.

Seasonal variation.-The color differences due to season are very slight, probably in part, at least, because of the little wear to which the plumage is usually subject. What little there is consists chiefly in the somewhat more brownish or lighter shade of the dark parts, 
both above and below, after the breeding season; and the sometimes more deeply ochraceous or tawny of the light markings in freshly plumaged birds.

Molt.-The natal plumage is naturally of brief duration, and with the beginning of the bird's growth in size passes directly into the juvenal plumage, which, in turn, through a practically continuous molt gives way to the first autumn plumage by at least some part of September, at which time the bird is full grown. During this process the wing-quills and rectrices are grown only once, but the contour feathers of the juvenal plumage are wholly or in large part replaced. This livery is worn until January or February, when by a complete molt the fully adult plumage is assumed.

The adult birds after the breeding season molt usually the contour feathers, but not the wing quills and rectrices, this taking place between the middle of July and the middle of September, mostly between July 15 and August 15. The birds are thus, with wings and tail intact, even though molting other feathers, free to start on their migration. During January or February another molt, this time complete, takes place, so that by the time the birds are ready for their long northward journey they have an entirely new suit. These different plumages have already been described.

Individual variation.-The differences exhibited by various individuals of the same sex and age is very great, with respect to both size and color, in all of the forms of this species. This variation in color affects chiefly the amount of light mottling on the upper sur. face; the fineness or coarseness of these markings; their color, which in some subspecies is so decided that it amounts to two phases; the width of the dark barring on the abdomen; the width and number of dark bars on the crissum, these in some individuals being heavy and close together, in others narrow or far apart; and the length of wing and tail. In only one or two of the subspecies are there really two color phases, gray and ochraceous or tawny, for such differences are usually subspecific. There is, moreover, usually not much purely individual variation in the shade of the dark brown or blackish areas, though occasionally such instances crop out in some of the races.

Geographical variation.-For a bird so highly migratory, Chordeiles virginianus has responded rather remarkably well to the climate, environment, and other modifying influences of the various parts of its breeding range. The number of subspecies that now appear recognizable is nine, an increase of two over the previous number. Two of these are West Indian, the others continental. Nearly all of them correspond very well to the characteristics exhibited by races of other species which range over areas of similar physiographic conditions, the principal exception being Chordeiles virginianus hes- 
peris, the Pacific coast race, which extends also eastward over the arid Great Basin. The four southeasternmost forms, Chordeiles virginianus aserriensis, Chordeiles virginianus chapmani, Chordeites virginianus vicinus, and Chordeiles virginianus minor are the smallest, and of these the two island races, $C . v$. vicinus and $C . v$. minor, represent the minimum. The five remaining races are all of large size and practically alike in this respect. It is interesting to note the reduplication of certain characters, such as the coloration of the upper parts, in forms widely separated geographically. Thus Chordeiles virginianus vicinus, except for its small size and more ochraceous lower surface, would pass very well for the far distant Chordeiles virginianus hesperis of Oregon and California; while Chordeiles virginianus minor of Cuba bears similar resemblance to Chordeiles virginianus henryi of Arizona. Furthermore, it is doubtless worth while to mention the development of blackish or dark grayish races in the northern and eastern portions of North America; of a light grayish form on the northern Great Plains; of light, rather ochraceous races in the middle Rocky Mountains, the southern part of the Great Plains, and in Texas; of a rather dark, very tawny or ochraceous subspecies in arid Arizona and New Mexico; and of a dark, very tawny or ochraceous but very small bird on the Greater Antilles.

The nine forms of Chordeiles virginianus here recognized are commonly considered subspecies, and correctly so. The Cuban Chordeiles virginianus minor indicates by the range of its individual variation its close connection with Chordeiles virginianus vicinus of the Bahama Islands, which race in turn overlaps in the same way the characters of Chordeiles virginianus chapmani. The last mentioned passes gradually through geographical intermediates into Chordeiles virginianus virginianus. In the same manner Chordeiles virginianus virginianus intergrades with Chordeiles virginianus sennetti and Chordeiles virginianus hesperis; and the last with both Chordeiles virginianus sennetti and Chordeiles virginianus howelli. ${ }^{1}$ Chordeiles virginianus howelli ${ }^{1}$ intergrades geographically with Chordeiles virginianus henryi, and both of these with Chordeiles virginianus aserriensis, which in turn connects with Chordeiles virginianus chapmani.

Most of the characters distinguishing the subspecies of Chordeiles virginianus lie in differences of size, chiefly of wing and tail, sometimes also of tarsus and middle toe; of the general tone of the upper surface, whether light or dark, grayish, blackish, buffy, ochraceous or tawny, this lightness or darkness due to the difference in ground color and in the color, abundance, and fineness of the light markings; of the general tone of the lower surface, whether light or dark, 
grayish, buffy or ochraceous; and of the width of the dark bars on the abdomen.

Geographical distribution.-As a species Chordeiles virginianus ranges, during the breeding season, in the West Indies and North America, form the northern edge of Mexico, the Gulf coast of the United States, and the Greater Antilles, north to the edge of the Barren Grounds in central. Quebec, northern Ontario, southern Mackenzie, and northern Yukon; and from the Atlantic coast to the Pacific. It migrates across Mexico, Central America, and through the West Indies to southern South America, where the various subspecies probably winter together.

The summer ranges of two of the races, Chordeiles virginianus aserriensis ${ }^{1}$ and Chordeiles virginianus vicinus, is somewhat restricted geographically, but most of the others are considerably extended. The northernmost form, Chordeiles virginianus virginianus, occupies an immense area stretching all the way across the continent, and at least equal in extent to the combined ranges of all the other subspecies.

The breeding areas of all but two of the forms of Chordeiles virginianus are continuous with some one or more of the others, although, of course, the lines delimiting the ranges on the accompanying map leave intermediate spaces due to lack of specimens from such regions. The subspecies of the Greater Antilles, Chordeiles virginianus minor, and that of the Bahama Islands, Chordeiles virginianus vicinus, are, of course, separated from each other and from the mainland forms by the surrounding water. The southeastern bird, Chordeiles virginianus chapmani, adjoins Chordeiles virginianus virginianus, Chordeiles virginianus howelli, ${ }^{2}$ and Chordeiles virginianus aserriensis. ${ }^{1}$ Also Chordeiles virginianus virginianus westward meets Chordeiles virginianus howelli, ${ }^{2}$ Chordeiles virginianus sennetti and Chordeiles virginianus hesperis; and the last also reaches Chordeiles virginianus sennetti. The central form of the west, Chordeiles virginianus howelli, ${ }^{2}$ lies surrounded by all of the six other mainland races, every one of which it touches at some part of the boundary of its range, as the distribution map shows. The far southwestern bird, Chordeiles virginianus henryi, adjoins, in addition, Chordeiles virginianus aserriensis on the southeast, and probably also Chordeiles virginianus hesperis on the northwest.

Zonal distribution.-In the West Indies during summer this species occupies the Upper Tropical Zone of the Neotropical Region; on the North American Continent the Lower Austral, Upper Austral, 
Transition, Canadian, and Hudsonian zones of the Nearctic Region. Four of the subspecies, Chordeiles virginianus aserriensis, ${ }^{1}$ Chordeiles virginianus chapmani, Chordeiles virginianus vicinus, and Chordeiles virginianus minor, are confined to a single life zone; one, Chordeiles virginianus sennetti, to two zones, and each of the four remaining races is spread over several zones. The ranges of all conform very satisfactorily to the boundaries of their respective zones.

Phylogeny.-As a species Chordeiles virginianus is, as already remarked, ${ }^{2}$ of South American origin. To the dispersal of strongwinged birds like this, physical features, such as high mountain ranges and wide expanses of water or desert, present no obstacle; and an unsuitable summer temperature and the lack of proper food at this season are therefore apparently its only real barriers. Thus its emigration from South America, from whatever primal cause, was easy, as was also the finding of a new home, since on account of its annual migratory return to the south, the only requisite for its new abode was a suitable place for reproduction. Its present distribution, routes of migration, and the evidently close relationship of the Cuban Chordeiles virginianus minor with Chordeiles acutipennis acutipennis from South America all indicate that Chordeiles virginianus reached the North American Continent through the West Indies. Birds that remained to breed on the Greater Antilles retained more nearly the original characters of the species, while those that pushed on northward and westward became more and more differentiated. The Floridian Chordeiles virginianus chapmani is, of course, the form least removed from the island birds, both geographically and phylogenetically. From this area the species probably spread northward and northwestward, where it developed into the large, dark race, Chordeiles virginianus virginianus. This, in turn, spread westward and southwestward over nearly the whole western United States, where environmental and perhaps other factors have produced the four large paler races of the more or less arid interior: Chordeiles virginianus hesperis, Chordeiles virginianus sennetti, Chordeiles virginianus howelli, and Chordeiles virginianus henryi; of which the last is undoubtedly phylogenetically as well as geographically farthest removed from Chordeiles virginianus virginianus. Simultaneously, in all probability, the advance of Chordeiles virginianus chapmani along the Gulf coast to southern Texas ultimately resulted in the development of the small, pale race in semiarid southern Texas. The uniformity of Chordeiles virginianus virginianus throughout its wide breeding range from ocean to ocean is apparently due to the comparative uniformity of climatic and en- 
vironmental conditions over this area, together with the very brief period of each year that the bird spends on its breeding grounds, where alone the differentiating influences have opportunity to exert themselves. Under these conditions it is entirely probable that any future development of geographical races from what is now the subspecies Chordeiles virginianus virginianus will be exceedingly slow.

Migration.-Comparatively few birds of any kind exceed this nighthawk in the length of their migration journeys, and very few land birds travel as far. From the Arctic Circle in the Territory of Yukon to Patagonia is more than 8,000 miles, but the nighthawk's long wings and consequent powers of flight enable it easily to perform this extensive regular annual journey. Judging from the scarcity of available records, it seems probable that the passage through Mexico and Central America, and over the West Indies, the Gulf of Mexico, and the Caribbean Sea to northern or central South America is made with considerable rapidity.

Like most other birds which travel long migration routes, this species is, generally speaking, an early migrant in autumn and a comparatively late arrival in spring. Notwithstanding this, the first individuals in spring sometimes reach the southern border of the United States by March 15, and the latest stragglers in autumn occasionally prolong their stay in the same region until even November 27 ; but these dates are of course exceptional, since the spring appearance is usually three or four weeks later, and the autumnal disappearance a month or so earlier. The nighthark usually reaches Montreal and Quebec early in May; Grand Falls, the northern limit of its range in central Quebec, during the last week of May; Fort Chipewyan, Alberta, the last week of May; Fort Wrigley, Mackenzie, the first week of June; and British Columbia by the last of May or first of June. On the other hand, migrant birds are sometimes still in southern Texas on May 29, and even in Costa Rica as late as May 27.

The southward migration must begin very soon after the young are on the wing, since transient birds from the north appear in the middle and southern United States by the first of August, sometimes by the middle of July; and they reach Nicaragua by the middle of September. Montreal in Quebec, also southern Manitoba and British Columbia, are deserted usually during the first two weeks of September, and Fort McMurray, Alberta, in August. It is thus evident that the migratory movements, in the United States at least, cover a total period of more than four months in autumn and of nearly three months in spring. There is thus in Colorado and the surrounding States a scant three or four weeks' period of summer, from about June 15 or 20 until the middle of July, during which the presence of a nighthawk is presumptive evidence of its breeding in the locality.

The above remarks apply to Chordeiles virginianus as a species, since sufficient data have not yet accumulated to work out the migra- 
tion of the subspecies separately. It is more than possible that an adequate series of specimens of the various races (for nothing else will answer) would show some interesting differences in their migration. The migration routes, however, by which several of the different races reach their common winter home in South America are discernible in a general way from the data now available. Concerning the migration of Chordeiles virginianus minor and Chordeiles virginianus vicinus we know nothing at all. The two eastern forms, Chordeiles virginianus chapmani and Chordeiles virginianus virginianus, fly southward across the Gulf of Mexico to Yucatan and through Central America to South America, or through the West Indies and across the Caribbean Sea. The return journey is apparently by the same route. The route of Chordeiles virginianus sennetti is unknown; but all the other western races pass south through Mexico and Central America and return the same way. A possible but unproved variation of this may take some or all of the birds from the easternmost part of the ranges of Chordeiles virginianus howelli, Chordeiles virginianus aserriensis, and Chordeiles virginianus hesperis across the western end of the Gulf of Mexico to Yucatan, and thence through Central America. There is no authentic record of any of these western races in the United States east of Illinois, or anywhere in the West Indies.

Habits. - Few birds bear such a misnomer as the nighthawk; for it is not a hawk, or even nearly related to one, nor is it a night-flier, except by moonlight, though it prefers the twilight and the declining hours of the day, as well as cloudy weather. It lives mostly in the open country, such as the plains and prairies, and is a common sight along roadsides, fence-rows, railroad tracks, and the like. It avoids the deep forest, though it often enters the outskirts of woodland. Its flight is strong, swift, and light, at times not a little suggestive of the sparrow hawk (Cerchneis sparveria) or other of the small falcons. It is much on the wing, and some of its aerial performances are really wonderful. Its ordinary call on the wing is a sharp one- or two-syllabled note something like " aeh-eek" or "peenk," and remarkably characteristic. The well-known booming sound so frequently heard is made by the quick passage of air between the primaries as the bird is suddenly checked in rapidly descending flight. Its food, which it obtains on the wing, consists probably all of insects, such as moths, flies, beetles, grasshoppers, and crickets.

This nighthawk lays its eggs on the ground on bare rocks, or even on the flat roofs of houses in cities. No nest at all is constructed. The time of nesting is somewhat earlier in the southern part of its range; but for the species as a whole, it lasts from late April to early August, though there is apparently but one brood. 
The two elliptical eggs are white, buff or gray, much marked throughout with blackish, drab, gray, olive, and plumbeous.

History.-This species was first brought to scientific notice in 1743, by Mark Catesby, in the supplement to his "Natural History of Carolina, Florida, and the Bahama Islands." He, however, confused the nighthawk (Chordeiles virginianus) and the whip-poorwill (Setochalcis vocifera), in which mistake subsequent authors for more than 50 years followed him. Alexander Wilson, in his "American Ornithology," 1 was the first to discriminate the two species satisfactorily, and to point out in detail the real differences between them.

The first technical description, however, applicable to any form of the species appeared in 1789, when Gmelin called the northeastern bird Caprimulgus virginianus. ${ }^{2}$ No subdivision took place until 1855, when Cassin separated the lighter western birds as Chordeiles henryi. ${ }^{3}$ In the following year the Cuban bird was described under two names, of which Doctor Cabanis' Chordediles minor ${ }^{4}$ has priority. Not until 1888 were any further races added, in which year Chordeiles virginianus sennetti was discovered and published, ${ }^{5}$ and the Florida bird separated as Chordeiles popetue [=virginianus] chapmani, both by Doctor Elliott Coues. ${ }^{5}$ Eight years later Mr. George I. Cherrie named a migrant bird from Costa Rica as Chordeiles virginianus aserriensis, ${ }^{6}$ which now proves to be the same as a hitherto unrecognized race from southern Texas. In 1903, Mr. J. H. Riley set apart a Bahama race as Chordeiles virginianus vicinus ; ${ }^{7}$ and in 1905 Mr. Joseph Grinnell separated the birds from the Pacific coast of the United States as Chordeiles virginianus hesperis. ${ }^{8}$ In the present paper one further subdivision is made, by restricting Chordeiles virginianus henryi chiefly to Arizona and New Mexico, and creating a new race from the northern and eastern part of its former range, Texas to Wyoming, under the name Chordeiles virginianus howelli. ${ }^{9}$ Although some of these above-mentioned forms of Chordeiles virginianus originally passed as distinct species, all are clearly but subspecies, since abundant evidence of intergradation exists in every case, either through geographical or individual intermediates.

\footnotetext{
${ }^{1}$ Amer. Ornith., vol. 5, 1812, pp. 78-82.

2 Syst. Nat, vol. 1, pt. 2, 17 S9, p. $102 \mathrm{~S}$.

${ }^{3}$ Illust. Birds Cal., Texas, Ore., Brit. and Russ. Amer., vol. 1, 1855, p. 239.

4 Journ. f. Ornith., January, 1856, p. 5.

${ }^{5}$ Auk, vol. 5, January, 1885, p. 37.

${ }^{6}$ Auk, vol. 13, April, 1896, p. 136.

7 Auk, vol. 20, October, 1903, p. 432.

${ }^{8}$ Condor, vol. 7 , Nov. 22,1905 , p. 170.

${ }^{9}$ See p. 57.
} 


\section{CHORDEILES VIRGINIANUS VIRGINIANUS (Gmelin).}

[Caprimulgus] virginianus Guelin, Syst. Nat., rol. 1, pt. 2, 1789, p. 1028 (Virginia) (based on: [Caprimulgus] europaus $\beta .[=]$ Caprimulgus minor americanus, Lrnndeus, Syst. Nat., ed. 12, rol. 1, 1766, p. 346; Hwipperiwill, Kald, Resa Norra Amer., vol. 3, 1761, p. 93 [Racoon, New Jersey]; Caprimulgus virginianus, Brisson, Ornith., vol. 2, 1760, p. 477 [Virginia]; Whip-poor-will, Caprimulgus minor Americanus, Catesbr, Nat. Hist. Carolina, Florida, and Bahama Islands, rol. 2, Appendix, 1743, p. 16, pl. 16 [Virginia]; Whip-poor-will, Edwards, Nat. Hist. Birds, vol. 2, 1747, p. 63, pl. 63 [Virginia]; Le Whip-pour-will, Buffon, Hist. Nat. des Oiseaux [orig. ed.], vol. 6, 1779, p. 534 [Virginia ] Longwinged Goatsucker, Pennant, Aretic Zool., vol. 2, 17S5, p. 436 [excl. pl. 1S], No. 337 [Charleston, South Carolina, to Henly House, Albany River, Ontario]; Virginia Goatsuclier, Latram, Gen. Synop. Birds, vol. 2, pt. 2, 1683, p. 595 [Virginia]).

Caprimulgus popetuc VIeIllot, Ois. Amer. Sept., vol. 1, 1S07, p. 56, pl. 24 (Nova Scotia).

Caprimulgus anericanus WrLson, Amer. Ornith., vol. 5, 1S12, p. 65, pl. 40 (eastern Pennsylvania) (nec Caprimulgus americanus LiNNeUs, 1758, qui siphonorlis americanus Auct.).

Caprimulgus variegatus Vienllot, Nouv. Dict. d'Hist. Nat., 2 d ed., vol. 10, 1S17, p. 238 (Paraguay).

C[aprimulgus]. jaspideus Mrenem, in Ersch und Gruber, Allgem. Encycl. Wissensch. und Künste, sec. 1, vol. 15, 1S26, p. 14 S (Paraguay).

Chars. subsp.-Size large; upper parts black or blackish, the light markings sparse or only moderately numerous, and mostly whitish or buffy, with very little tawny; general tone of lower surface relatively dark, the dark areas of anterior portion blackish, the posterior part slightly washed with cream color or buff, and heavily barred with blackish.

Description.-Adult male, No. 38895, Museum Comparative Zoölogy, Pocantico, New York, May 19, 1891; W. E. D. Scott; original number, 11425. Upper surface blackish clove brown, irregularly spotted with brownish white, cream white, cream color, cream buff, buff, ochraceous buff, and ochraceous, these markings most numerous on cervix, largest on scapulars (which are also much mottled with grayish and buffy on their subterminal unexposed portions), least frequent on pileum and back, which are almost unmarked, and in the form of irregular bars on the upper tail-coverts; tail grayish clove brown, crossed by about seven (none of which is terminal) irregular and broken bars of brownish white, buffy white, and pale brown, these bars widest on the middle pair of rectrices, and by a broad subterminal band of white on all but the two middle feathers; wingquills dark brown, like the tail, but slightly darker, the outer six primaries crossed by a broad band of pure white posteriorly (distally) to the tip of the ninth primary (counting from the outermost); secondaries and inner primaries narrowly tipped with pale brownjsh; outer half or so of the inner webs of the secondaries with 
narrow brownish or buffy white bars; the tertials mottled with light brown, brownish white, and buffy white in the form of broad but much broken and obsolescent bars; superior wing-coverts grayish clove brown like the quills, the primary coverts immaculate, the others spotted irregularly and rather thickly, but not confluently, with brownish white, cream white, and cream buff; moustachial stripe and sides of head and neck blackish clove brown, the auriculars and subocular region narrowly streaked with deep tawny, the sides of neck anteriorly broadly streaked with tatwny ochraceous, posteriorly more or less spotted with buffy and brownish white; the moustachial stripe spotted with cream white and buff; a superciliary stripe consisting of small spots of anteriorly cream white, posteriorly cream buff, confluent with the light streaks on the side of the neck and the light spots on the cervix; lores mixed with whitish; a broad gular crescent and the middle of chin pure white; jugulum and upper breast grayish seal brown, the former with conspicuous subtriangular spots of tawny ochraceous and cream buff, the latter with spots and irregular or broken bars of cream color, cream white, and brownish white; rest of lower surface cream buff, heavily barred with the brown color of wing-quills, these bars widest and farthest apart on crissum; inferior wing-coverts brown like the wings, somewhat spotted and irregularly barred with cream white, cream buff, and ochraceous buff; axillars dark brown, barred with buff and cream white; edge of wing along the alula white.

Iris black or hazel brown; bill black or dark brown; feet dark brown, dull grayish brown, or plumbeous.

Measurements.-Male: Total length (in flesh), 235-247.6 (average, $241.9) \mathrm{mm}$. ; $^{1}$ extent of wing, 596.9-622.3 (610.7). ${ }^{1}$

Female: Total length (in flesh), 228.6-254 (241.5) ; $;^{2}$ extent of wing, 533.4-606 (574.4). ${ }^{3}$

Male: ${ }^{4}$ Wing, 184-208 (average, 198) mm.; tail, 106-118 (110.9); exposed culmen, 6.1-7.5 (6.5) ; tarsus, $13.5-15.2$ (14.4); middle toe, $13-15.5(14.9)$.

Female: ${ }^{5}$ Wing, 187.5-203 (196.5) mm.; tail, 105-118.5 (112); exposed culmen, 6.2-7.2 (6.7) ; tarsus, 13.8-15.5 (14.8); middle toe, 14-16.5 (15.5).

Type-locality.-Eastern Virginia.

Geographical distribution.-Eastern and northwestern North America, south in winter to southern South America. Breeds in the

${ }^{1}$ Six specimens.

2 Nine specimens.

${ }^{3}$ Seven specimens.

* Twelve specimens, from Nova Scotia, Quebec, Alberta, British Columbia, New Hampshire, Massachusetts, and New York.

5 Ten speeimens, from Nova Scotia, Ontario, Maine, Massachusetts, Pennsylrania, and West Virginia. 
Upper Austral, Transition, Canadian, and lower part of the Hudsonian zones, north to Grand Falls on the Hamilton River, and to Lake Mistissini, central Quebec; Moose Factory, northern Ontario; York Factory and Fort Churchill, northeastern Manitoba; Fort Chipewyan and Fort Smith, northeastern Alberta; Fort Resolution and Fort Providence, central southern Mackenzie; Fort Wrigley, the western part of Great Bear Lake, and the Mackenzie River just below Fort Good Hope, central western Mackenzie; and La Pierre House, northern Yukon; west to La Pierre House, northern Yulion; mouth of the Tatchun River, White Horse Rapids, and Caribou Crossing on the Yukon River, and the northern end of Lake Teslin in central southern Yukon; Telegraph Creek, the Coast Range, Lund on Malaspina Inlet, Comox, and Errington on Vancouver Island, western British Columbia; south to Victoria, southwestern British Columbia; Semiahmoo, northwestern Washington; Sumas and Osoyoos Lake, central southern British Columbia; Sproat's Landing on the Columbia River, southeastern British Columbia; Banff, southwestern Alberta; Prince Albert and Quill Lake, south central Saskatchewan; Carberry, southern Manitoba; Walker and St. Cloud, central Minnesota ; Waseca, central southern Minnesota ; Forest City, central northern Iowa; Ames, central Iowa ; Indianola, south central Iowa; Omaha, Lincoln, and Beatrice, southeastern Nebraska; Topeka, central eastern Kansas; Jasper in Jasper County, and Marble Cave in Stone County, southwestern Missouri; Pettigrew, northwestern Arkansas; Mammoth Spring, central northern Arkansas; Monteer, central southern Missouri; St. Louis, central eastern Missouri; Odin, southern Illinois; Terre Haute, Bloomington, and Bedford, southern Indiana; Bowling Green, central southern Kentucky; Nashville, central Tennessee; Chattanooga, southeastern Tennessee; Ellijay and Young Harris, central northern Georgia; Asheville and Weaverville, south western North Carolina; Wytheville, Lynchburg, Newport News, and Cape Charles, southern Virginia; east to Cobbs Island, eastern Virginia; Ocean View, eastern Delaware; Five Mile Beach and Sea Isle City, eastern New Jersey; Montauk, eastern Long Island; Newport, southern Rhode Island; Woods Hole, Boston, and Ipswich, eastern Massachusetts; Portsmouth, southeastern New Hampshire; Bath, Mount Desert Island, and Calais, southern Maine; Barrington, Halifax, and Sydney, eastern Nova Scotia; Anticosti Island, and the Natashkwan River, eastern Quebec; and the Bay of Islands, western Nerffoundland. Migrates south through Colorado, Texas, eastern Mexico, southeastern United States, the Bermuda Islands, Cuba, Isle of Pines, Jamaica, Barbados, Costa Rica, and Panama, to South America. Winters in South America, north to the Orinoco Rirer in central Venezuela, and Bogota, central Colombia; west to Bogota, Colombia; Matto Grosso, western Brazil; Tucuman, northwestern 
Argentina; and Cordoba, north central Argentina; south to Barracas al Sud, Province of Buenos Aires, central eastern Argentina; and east to Buenos Aires, central eastern Argentina; Sas Paulo and Rio de Janeiro, southeastern Brazil; and Guiana. Accidental north to Melville Island, northern Canada.

Remarks.-In the adult female of this race the posterior lower parts are much more tinged with buff or ochraccous than in the male; and the ground color of the upper surface averages lighter, duller, and more brownish, with more numerous light markings, which are more buffy or ochraceous.

Birds in first autumn plumage are, on the upper surface, almost like the average of adult Chordeiles virginianus hesperis, and similar also to the adult of Chordeiles virginianus sennetti, but the dark areas are more intensely blackish, though occasional specimens are indistinguishable in this respect.

The adult male is normally very deeply blackish above, with a comparatively small amount of light mottling; but he varies individually to dull brownish; with a large amount of light marking, until he becomes almost indistinguishable from dark examples of Chordeiles virginianus howelli. ${ }^{1}$ Light-colored specimens of this sort are No. 88139, U.S.N.M., Stamford, Connecticut, and No. 13249, E. A. and O. Bangs, Santa Fe, Isle of Pines. The light markings of upper parts are usually grayish, creamy white, and buff, but vary sometimes to almost pure white, sometimes to deep tawny. The ground color of the lower parts is normally grayish white, and varies little, though sometimes almost pure white, sometimes slightly washed with buff. The female is also variable above, and occasionally (such as No. 174915, U.S.N.M., Cumberland County, New Jersey; and No. 46920, Mus. Comp. Zoöl., Long Island, New York) very closely resembles adult male Chordeiles virginianus hesperis. The ground color of the ventral surface is commonly cream white, but deepens in some birds to ochraceous buff. The light throat-patch is normally buff, ranging, however, on the one hand to cream white, on the other to deep ochraceous buff.

Notwithstanding its vast range, this subspecies exhibits almost no geographical variation, except where its breeding area closely approaches that of some other lace. Adult birds from Vancouver Island, British Columbia, and from the Iukon River in Yukon are apparently in no respect, of either size or color, distinguishable from those of Nova Scotia, eastern Quebec, and New England. A single female from Sproat's Landing, southeastern British Coulmbia (No. 970, Victoria Mem. Mus., June 26, 1890), and another, a male, from Banff, Alberta (No. 1256, Victoria Mem. Mus., June 8, 1891), both seem to be typical of Chordeiles virginianus virginianus, and appar- 
ently represent the breeding form at these localities. Specimens from Ashcroft, Lac La Hache, Hope, and Chilliwack, in southern British Columbia, have considerable indication of the more brownish, more heavily light-mottled upper surface of Chordeiles virginianus hesperis, but are, on the whole, nearer Chordeiles v. virginianus. An adult from Carberry, Manitoba (No. 57875, Am. Mus. Nat. Hist., July 29, 1892), and a half-grown young from the same locality (No. 57876, Am. Mus. Nat. Hist., Aug. 1, 1892) are somewhat vergent toward Chordeiles virginianus sennetti, but are not pale enough above for the latter and apparently belong under the typical form. Another adult from Winnebago County, Iowa (No. 26724, A. N. S. Phila., Sept. 1, 1879), which seems to represent the breeding bird of this locality, is likewise intermediate, but nearer Chordciles $v$. virginianus. A typical example of Chordeiles v. virginianus from Trail, extreme southeastern British Columbia (No. 2811, Victoria Mem. Mus., June 14, 1902), is doubtless a migrant, since the breeding subspecies at this place is Chordeiles virginianus hesperis. Similarly migrant also doubtless are two adult males (No. 15638 and No. 15639, L. B. Bishop, June 5, 1906) from Maple Creek, southwestern Saskatchewan, where the breeding subspecies is Chordeiles $v$. hesperis. Two other adult males (No. 13449 and 3578, L. B. Bishop), respectively from Stump Lake, N. Dak., August 2, 1905, and Towner County, N. Dak., June 8, 1897, are likewise best considered migrant Chordeiles $v$. virginianus, though verging a little toward $C$. v. hesperis, since the breeding bird of these localities is Chordeiles virginianus sennetti, and these two specimens are too dark for that race. Another example (No. 63939, U.S.N.M.), from Pembina, N. Dak., taken June 16, 1873, is unquestionably perfectly typical of C. v. virginianus, and hence a belated migrant, for we have an actually breeding female of Chordeiles virginianus sennetti from this same locality, taken three days earlier. A single individual from Cushion Lake, southeastern Missouri (No. 205012, U.S.N.M.), is typical Chordeiles $v$. virginianus, but does not, in all probability, represent the breeding form of this locality, which form is reasonably sure to be Chordeiles virginianus chapmani. A single male, perhaps a migrant, from Richland County, southeastern Illinois (No. 90781, U.S.N.M., May 2., 1883), is apparently nearer the typical subspecies, though the breeding bird of the adjoining county of Wabash is Chordeiles virginianus chapmani.

Birds taken on Smiths Island, southeastern Virginia, prove to be smaller than northern specimens, and are, in fact, about half way between Chordeiles virginianus virginianus and Chordeiles virginianus chapmani; but, both size and coloration taken into consideration, seem to be nearer the former. A single adult female, from Fort Macon, North Carolina (No. 57903, U.S.N.M.), taken June 10, 1869, 
seems to be undoubtedly of the present race, being altogether too large for Chordeiles virginianus chapmani; if so, it is only a late migrant, because a male collected at the same locality on the same day is certainly Chordeiles v. chapmani, the breeding form of the region. Specimens from various parts of the breeding range of Chordeiles virginianus virginianus exhibit the following average measurements:

\begin{tabular}{|c|c|c|c|c|c|}
\hline Localities. & Wing. & Tail. & $\begin{array}{l}\text { Exposed } \\
\text { culmen. }\end{array}$ & Tarsus. & $\begin{array}{l}\text { Middle } \\
\text { toe. }\end{array}$ \\
\hline $\begin{array}{l}\text { Eight males, from Quebec, Nova Scotia, Now Hamp- } \\
\text { shire, Massachusetts, and New York.............. }\end{array}$ & $\begin{array}{l}m m . \\
19 S .1\end{array}$ & $\begin{array}{l}m m . \\
111.5\end{array}$ & $\begin{array}{r}m m . \\
6.5\end{array}$ & $\begin{array}{l}m m . \\
14.6\end{array}$ & $m m$ \\
\hline Two males, from Alberta. . . . . . . . . ....... & 192.8 & 111.5 & 6.5 & 13.8 & 14 \\
\hline Two males, from British Columbia.................. & 202.5 & 107.8 & 6.8 & 14.3 & 15.3 \\
\hline Five males, from southeastern Virginia...... & 193.3 & 110.1 & 6.6 & 14.5 & 15.2 \\
\hline $\begin{array}{l}\text { Ten females, from Nova Scotia, Ontario, Massachu- } \\
\text { setts, Maine, Pennsylvania, and West Virginia.... }\end{array}$ & 196.5 & 112 & 6.7 & 14.8 & 15.5 \\
\hline Six females, from southeastern Virginia............. & 185 & 109.3 & 7 & 14.7 & 15.1 \\
\hline
\end{tabular}

In view of the fact that the migration route of this subspecies is across the Gulf of Mexico and through, or rather over, the West Indies, there are surprisingly few records from these islands, even the Greater Antilles. A single specimen, taken, September 29, 1887, on the island of Barbados, ${ }^{1}$ is the only authentic record from any of the Lesser Antilles. There are no certain records from any part of Mexico excepting the northeastern corner (Nuevo Leon, May $19^{2}$ ), nor from Central America northwest of Costa Rica. The single bird found dead, in 1820, on Melville Island, Franklin Territory, Canada, ${ }^{3}$ was, of course, a mere straggler so far beyond even the northernmost extension of the breeding range of the subspecies.

Except, perhaps, in the southern part of its range, Chordeiles virginianus virginianus rears but a single brood. In the south it breeds chiefly in May and June, and there is record of eggs as early as April 28; in the north, during June and July, and there are unhatched eggs to be found sometimes as late as July 31 .

The earliest binomial name for the eastern nighthawk is Caprimulgus virginianus of Gmelin, ${ }^{4}$ based on the bird from Virginia. His diagnosis is in full as follows:

C[aprimulgus]. fuscus, transversim griseo-fusco et hinc inde cinereo-varius, subtus ex rubescente albus transversim striatus, menti macula trigona alba, area oculorum et cervice aurantiis maculis varia.

Habitat aestate in America septentrionali, praesertim Virginia, europaeo minor, 8 pollices longus, in montanis, vespere prope domus frequens, eoque tempore

${ }^{1}$ Feilden, Ibis, 1889 , p. 486.

2 Hartert, Cat. Birds Brit. Mus., vol. 16, 1892, p. 611.

s Sabine, Suppl. Appendix Parry's 1st. Voyage, 1824, p. cxciv.

' Syst. Nat., vol. 1, pt. 2, 1789, p. 1028. 
ad ortum solis usque saepissime altissima voce wiperi-wip clamans, ova 2 viridia, maculis et striis atris varia in campo aperto in nudu terra pariens. Caro sapida.

Genae ex cincreo fuscae; remiges atrac, 5 primae circa medium, rectrices extimae prope apiccm macula alba notatae; pedes incarnati.

From this it is readily discernible that his description of the bird is applicable to only the nighthawk, but that the particulars concerning its habits relate nearly or quite all to the whip-poor-will (Setochalcis vocifera). The source of this confusion lies in the accounts of the species given by the eight previous authors whose works Gmelin cites, which citations we have given in full above in the synonymy of the present race. ${ }^{1}$ Of these the Caprimulgus minor americanus of Linnæus ${ }^{2}$ is based exclusively on the descriptions in the works of Catesby, Kalm, and Edwards. Catesby's account ${ }^{3}$ of his "Whip-poor-will," or "Caprimulgus minor Americanus," from Virginia, which is apparently the earliest extended notice of the species, relates certainly, so far as the plate and description of the bird are concerned, though neither is entirely accurate, to Chordeiles virginianus virginianus; but the habits that he describes are just as certainly those of Setochalcis vocifera. What Catesby says about habits is practically all in a letter from a Mr. Clayton, of Virginia, which he quotes, as follows:

The Whippoorwill is not so large as the Bird called here the East-India Bat, i. e., Caprimulgus, but in shape, and colour of the feathers, it very mnch resembles it, having also at each side of its mouth three or four stiff black hairs like those of a horse's main, two or three inches long. These birds risit us about the middle of April, from which time, till the end of June, they are heard erery night, beginning about dusk, and continuing till break of day; but it is chiefly in the upper or western parts that they are so very frequent. I never heard but one in the maritime parts, although my abode has been always there; but near the mountains, within a few minutes after sun-set, they begin, and make so very loud and shrill a noise all night, which the echoes from the rocks and sides of the mountains increase to such a degree, that the first time I lodged there I could hardly get any sleep. The shooting them in the night is very difficult, they never appearing in the daytime. Their cry is pretty much like the sound of the pronunciation of the words Whip-poor-will, with a kind of chucking noise between erery other or every two or three cries, and they lay the accent very strong upon the last word Will, and least of all upon the middle one.

The Indians say these Birds were nerer kuown 'till a great massacre was made of their countryfolks by the English, and that they are the Souls or departed Spirits of the massacred Indians. Abundance of people here look upon them as Birds of ill omen, and are rery melancholy if one of them happens to light upon their house, or near their door, and set up his cry (as they will sometimes upon the rery threshold) for they verily believe one of the family

1 See p. 35.

2 Syst. Nat., ed. 12, vol. 1, 1766, p. 346.

${ }^{3}$ Nat. Hist. Carolina, Florida, and Bahama Islands, vol. 2, Appendlx, 1743, p. 16, pl. 16. $13732^{\circ}-$ Bull. $86-14-4$ 
will die very soon after. These Birds, as I hare been credibly informed, breed exactly as the Goat-Sucker before mentioned, which is thus: they lay only two eggs of a dark greenish colour, spotted and scrawled about with black, in the plain beaten paths, without the least sign of any nest, upon which they sit very close, and will suffer a rery near approach before they fly off.

Kalm, ${ }^{1}$ who calls the bird "Hwipperiwill," gives much the same sort of an account. Edwards, ${ }^{2}$ Latham, ${ }^{3}$ and Buffon, ${ }^{4}$ all give a good description of the nighthawk, but reproduce Catesby's account of the habits of the whip-poor-will, Edwards giving it in Catesby's (=Clayton's) own language. Pennant's description of his "Longwinged Goatsucker" "relates wholly to Chordeiles virginianus, but his plate is Setochalcis vocifera. Brisson gives a detailed description, ${ }^{\circ}$ which applies wholly to the nighthawk. It is interesting to note how closely all these subsequent authors have copied Catesby, with very little or no additional information; except Brisson, whose long, careful description is evidently original. Since in all these accounts the portions descriptive of the plumage and other specific characters relate entirely to the nighthawk, the name Caprimulgus virginianus of Gmelin has a clear title.

The Caprimulgus popetue of Vieillot, ${ }^{7}$ from Nova Scotia, is, of course, a synonym of Caprimulgus virginianus Gmelin, being many years posterior, though a number of authors have used it for the species. Wilson's Caprimulgus americanus, ${ }^{8}$ from eastern Pennsylvania, is also the same. There seems to be no reasonable doubt concerning the identification of Caprimulgus jaspideus Merrem ${ }^{\circ}$ and Caprimulgus variegatus Vieillot, ${ }^{10}$ both from Paraguay, for the accompanying descriptions agree very closely with Chordeiles virginianus virginianus.

As will be seen by the quotation from Gmelin given above, ${ }^{11}$ Virginia is mentioned as the particular part of North America in which this bird was supposed to be found. Most of the other authors whom Gmelin cites give Virginia as the locality also. They mention western. Virginia especially, but since this is so evidently based on the account of habits, which are plainly those of Setochalcis vocifer'a, and since the specimens that served as the basis for the descrip-

\footnotetext{
${ }^{1}$ Resa Norra Amer., vol. 3, 1761, p. 93.

${ }^{2}$ Nat. Hist. Birds, vol. 2, 1747, p. 63, pl. 63.

s Gen. Synop. Birds, vol, 2, pt. 2, 1783, p. 595.

4 Buffon, Hist. Nat. des Oiseaux, vol. 6, 1779, p. 534.

${ }^{5}$ Arctic Zool., vol. 2, 1785, p. 436.

B Ornith., vol. 2, 1760, p. 477.

7 Ois. Amer. Sept., vol. 1, 1807, p. 56, pl. 24.

${ }^{8}$ Amer. Ornith., vol. 5,1812 , p. 65, pl. 40.

${ }^{8}$ In Ersch and Gruber, Aligem. Encycl. Wissensch. und Küinste, sec. 1, vol. 15, 1826, p. 148.

${ }^{10}$ Nouv. Dict. d'Hist. Nat., 2d. ed., vol. 10, 1817, p. 238,

11 See p. 40.
} 
tions came in all probability from the eastern portion of this State, it seems best to fix the type-locality, which we do here, as eastern Virginia.

Specimens examined.-Of this race 198 specimens have been examined, from the following localities:

Alberta.-Athabaska Lake (June 1, 1901); Slave River, 10 miles below Peace River (June 7, 1901); Banff (June 8, 1891).

British Columbia.-Wayne Island (Aug. 19, 1892); Vernon (Aug. 4, 1892) ; Ashcroft (July 2,3, 5, and 8, 1889); Sumas (Aug. 8, 1891); Trail (June 14, 1902); Errington, Vancouver Island (Aug. 29 and 30, 1910; Sept. 9 and 15, 1910); Osoyoos Lake (June 6, 1905); Hope (Sept. 3, 1890); Lac La Hache (June 29, 1892); Sproat's Landing, Columbia River (June 26, 1890); Chilliwack (June 29, 1859); Okanagan Falls (June 19 and 21, 1913) ; Penticton (June 23 and 27, 1913); New Westminster (June 4, 1886); Victoria (July 25, 1894).

Mackenzie.-Mackenzie River, below Fort Good Hope.

Manito乙a.-Carberry (July 29, 1892; Aug. 1, 1892) ; Lake Winnepegosis (July 3 and 5,1913 ).

Nova Scotia.-Digby (July 14, 1907); Newport (Aug. 21, 1900).

Ontario.-Moose Factory (Aug. 4, 1860; Aug. 16, 1860) ; Brunswick House (June 9, 1908) ; Point Pelee (May 29, 1909).

Quebec.-Fauriel, Grosse Isle, Magdalen Islands (June 15, 1901).

Sastiatchewan.-Maple Creek (June 5, 1906).

Yukon.-White Horse Rapids, Yukon River (July 11, 1899); Caribou Crossing, Yukon River (June 27, 1899).

Colorado.-Gunnison (Aug. 24, 1885).

Connecticut.-Stamford; East Hartford (Aug. 5, 1893).

Florida.-Whitfield (May 2, 1903; Apr. 15, 23, and 28, 1903) ; Dry Tortugas (Apr. 13 and 14, 1890); Amelia Island (May 16, 1906; Apr. 20, 1906).

Illinois.-Jacksonville (May 21, 1892); Lake Forest (May 19 and 23, 1906) ; Richland County (May 25, 1883).

Iowa.-Winnebago County (Aug. 12 and 26, 1879; Sept. 1 and 3, 1879); Grinnell.

Kansas.-Hamilton (Aug. 10, 1913).

Maine.-King and Bartlett Lake, Somerset County (July 15, 1893); Island Falls (Sept. 17, 1878).

Maryland.-Cornfield Harbor (July 18, 1894); Takoma (May 11, 1896; Capitol View (May, 1899); Piney Point (July 17 and 20, 1889); Laurel (Aug. 2, 1889; Sept. 13 and 27, 1889); Aikin (Aug. $30,1894)$.

Massachusetts.-Wayland (Sept. 17, 1879) ; Waltham (May 18, 1878); Great Island (July 14, 1891); Dorchester (Sept. 1 and 8, 
1887); Brookline (June, 1872); Wareham (June 10, 1893) ; Cotuit (July 15, 1879) ; Marshfield (July 14, 1879); Cambridge; Princeton. Michigan.-Palmer Park, Wayne County (May 26, 1907).

Minnesota.-Fort Snelling. (May 22, 1890; June 4, 1891); Grant County (spring, 1877; May 20, 1876) ; Moorhead (Aug. 31, 1912: Sept. 28, 1912).

Missouri.-Charleston (May S, 1879; May 6, 1878) ; Marble Cave, Stone County (June 30, 1892); Cushion Lake (May 6, 1909).

New Hampshire.-Hollis (July 27, 1886; May 26, 1876).

New Jersey.-Corona, Bergen County (Aug. 29, 1888); Mount Ephraim (Sept. 10, 1884); Cumberland County (Aug. 23, 1887) ; Cape May (May, 1842).

New Yort.-Baldwin, Long Island (Sept. 3, 1908) ; Good Ground, Long Island (July 3, 1884); New York (1871); Lake Grove (May 30, 1889) ; Hastings-on-Hudson (May 30, 1892) ; Shelter Island, Suffolk County (Oct. 15, 1897) ; Pocantico (May 19, 1891) ; Roslyn, Queens County (September, 1887).

North Carolina.-Fort Macon (June 10, 1869) ; Raleigh (Aug. 31, 1894); Weaverville (May 24, 1893).

North Dakota.-Pembina (June 16, 1873); Turtle Mountains (June 8, 1897) ; Stump Lake, Nelson County (Aug. 2, 1905).

Pennsylvania.-Carlisle (May 16, 1844 ; June 10, 1844); Chester County (June 2, 1894; Aug. 21, 1894); Chestnut Hill, Philadelphia (May 7, 1880; Sept. 10, 1878) ; Marple, Delaware County (May 23, 1881) ; Erie (May 18, 1889) ; Bethesda (July 13, 1896) ; Big Tink Pond, Pike County (Aug. 26, 1908).

South Carotina.-Ladys Island (May 12, 1869).

Tennessee.-Bellevue, Davidson County (May 23, 1895); Strawberry Plains.

Texas.-Brownsville (May 4, 1889); Corpus Christi (May 28 and $29,1891)$.

Virginia._Dunn Loring (Sept. 2, 1891); Arlington (Aug. 22, 1879); The Isaacs (May 24, 1899); Smiths Island (May 21, 1894; May 9 and 27, 1899; May 20, 1910; June 4, 12, 23, and 30, 1899); Gainesville (Aug. 25 and 29, 1887; Aug. 14, 1886).

West Virginia.-White Sulphur (July 8 and 19, 1898).

Wisconsin.-Camp Douglas (Aug. 12, 1891); Cassville (June 3, 1912) ; Lake Koshkonong (June 24, 1873; July 8, 1873).

Campeche.-La Tuxpana (Sept. 28, 1912).

Argentina.-Ysca Yacu, Province of Santiago (Jan. 31, 1906).

Costa Rica.-Rio Sicsola, Talamanca (Sept. 24, 1904); Miravalles (May 25, 1906).

Isle of Pines, West Indies.-Santa Fe (May 10, 1904).

Jamaica.-Spanishtown (September, 1863). 
Measurements of specimens of Chordeiles virginianus virginianus.

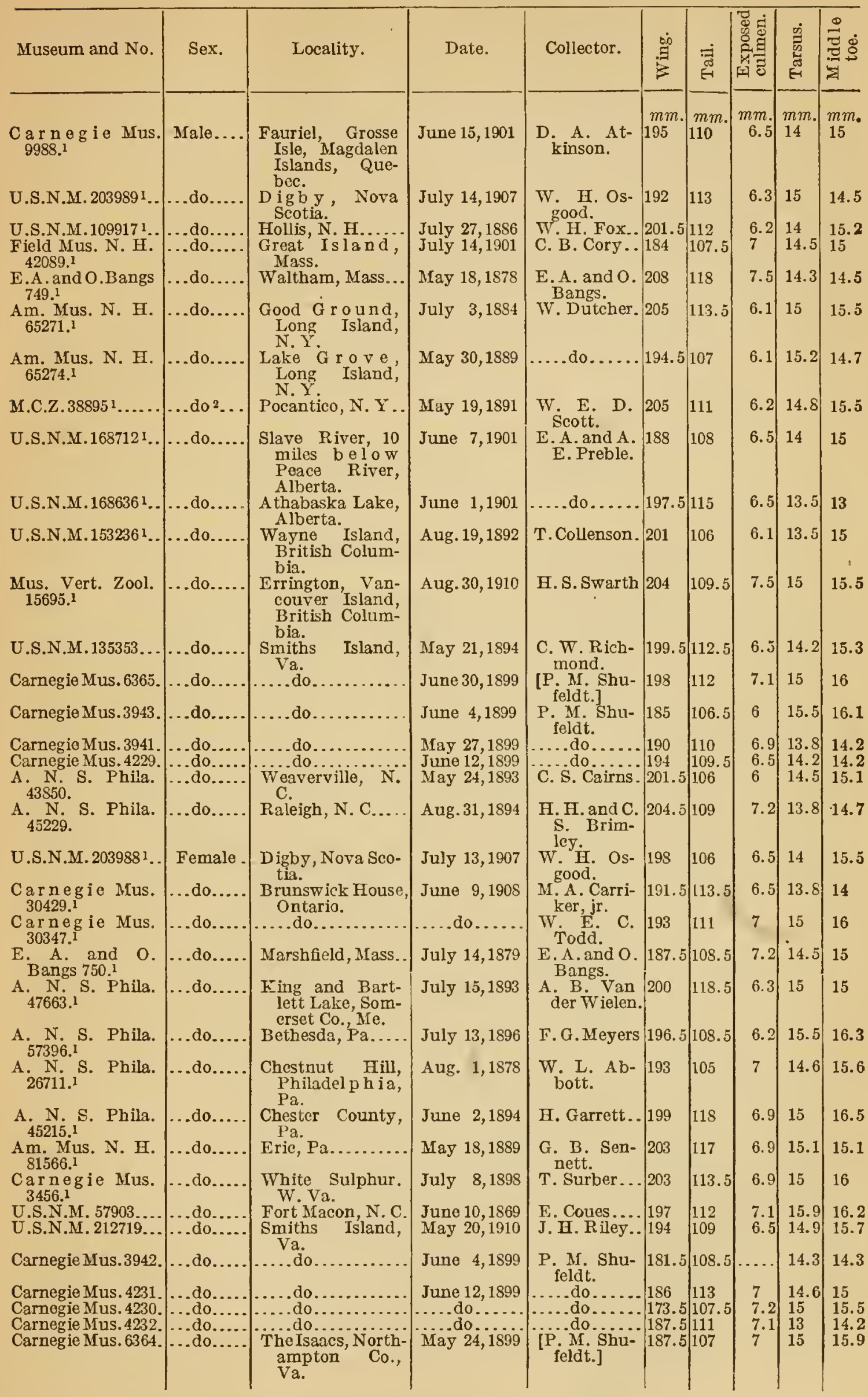


CHORDEILES VIRGINIANUS HESPERIS Grinnell.

Chordeiles virginiamus hesperis Grinnelt, Condor, rol. 7, Norember 22, 1905, p. 170 (Bear Lake, San Bernardino Mountains, California).

Chars. subsp.-Similar to Chordeiles virginianus virginianus, but male with upper surface lighter, the ground color more brownish, the light markings more numerous, particularly on back, scapulars, tertials, and superior wing-coverts; the posterior lower parts less washed with buffy, and the dark bars averaging narrower.

Measurements.-Male: Total length (in flesh), 220.7-260.3 (average, 240.5) mm.; ${ }^{1}$ extent of wing, 568.2-609.6 (588.9). ${ }^{1}$

Female: Weight, 4 ounces avoirdupois. ${ }^{2}$

Male: ${ }^{3}$ Wing, 183-211 (average, 200) mm.; tail, 107-120 (112.9); exposed culmen, 6.0-8.0 (6.9) ; tarsus, 13.8-15.2 (14.3) ; middle toe, $14-15.5(14.7)$.

Female: ${ }^{4}$ Wing, 187-203 (194.9) mm.; tail, 105-119 (112.2); exposed culmen, 6.1-8.0 (7.0); tarsus, 13-15.2 (14.5); middle toe, 14.2-16 (15.3).

Type-locality.-Bear Lake, 6,700 feet altitude, San Bernardino Mountains, southern California.

Geographical distribution.-Extreme western United States and southern edge of southwestern Canada; south in winter, probably to South America. Breeds in the Upper Austral, Transition, and Canadian zones, north to Indian Head and Maple Creek, southern Saskatchewan; Many Island Lake, near Walsh, southeastern Alberta; Trail, southeastern British Columbia; and Fort Steilacoom, Puget Sound, northwestern Washington; west to Aberdeen, central western Washington; Astoria, Newport, and Glendale, western Oregon; Humboldt Bay and Ukiah, northwestern California; Auburn in Placer County, central California; and the Kern River Lakes and Santa Barbara, southwestern California; south to Venturia County, and to the South Fork of the Santa Ana River, and Fish Creek in the San Bernardino Mountains, southwestern California; east to Sugarloaf Peak in the San Bernardino Mountains, southwestern California; Furnace Creek in Death Valley, southeastern California; Mount Magruder, southwestern Nevada; Eureka, central Nevada; Fairfield, north central Utah; Promontory, central northern Utah; Blackfoot, southeastern Idaho; Upper Geyser Basin, in Yellowstone National Park, northwestern Wyoming; Bozeman, Great Falls, and the Bear Paw Mountains, central Montana; and Indian Head, central southern Saskatchewan. Migrates southward through Kansas, Colorado, Arizona, New Mexico, Texas, Mexico, and Nicaragua. Winters probably in South America.

\footnotetext{
1 Two specimens.

2 One spccimen.

${ }^{3}$ Ten spectmens, from Calffornia, Oregon, and Montana.

4 Ten specimens, from Callfornia, Oregon, aud Idaho.
} 
Remarks. -The female of this race differs in color from the male in hel usually more buffy posterior lower parts; rather lighter, more brownish (less blackish) ground color of the upper surface, with light markings there averaging darker, duller, less sharply contrasted with the dark areas, and usually somewhat more ochraceous or brownish (less whitish). She is, in fact, more like Chordeiles virginianus howelli ${ }^{1}$ than is the male. She is even more different from the female of Chordeiles virginianus virginianus than is the male from that form, being rather readily separable by her lighter, more brownish (less blackish), more heavily light-mottled upper parts, these light markings paler tawny or ochraceous; paler under surface, the dark brown areas less blackish, the tawny and ochraceous parts, including the throat, paler, the posterior portion more narrowly barred and less strongly tinged with buff or tawny.

The juvenal and first autumn plumages are distinguishable from the same stages of Chordeiles virginianus virginianus and Chordeiles virginianus chapmani by their lighter upper surface, the ground color of which is more brownish, the light markings usually somewhat more buffy and more numerous. Most specimens are, on the upper surface, very much like adult male Chordeiles virginianus sennetti, occasional birds almost indistinguishable, but are rather more brownish and buffy.

Individual variation in color is very marked, more so in the female than in the male. In the male the ground color of the lower parts is normally creamy white, varying to pure white and to cream buff; in the female normally cream buff, varying to cream white and to ochraceous buff, the light throat-patch ranging from ochraceous buff to buffy white. The upper surface of the male is normally blackish brown, with considerable light mottling, mostly of white and grayish white, with some buff. The general impression is lighter than in Chordeiles virginianus virginianus, darker than in Chordeiles virginianus sennetti. Sometimes it is more blackish, sometimes more brownish, and the mottlings are occasionally, at least in part, ochraceous buff. The upper surface of the femade is normally as described above, but varies occasionally (No. 161983, U.S.N.M., Quincy, California, June 21, 1889) to dark grayish brown with extensive white, scarcely any buff, markings, practically as in typical male Chordeiles virginianus sennetti; to a more extensively blackish general color (No. 94978, U.S.N.M., Fort Klamath, Oregon, July 25, 1883), with few light markings, very much like the adult male $C$ hordeiles virginianus virginianus; to a more rufescent brownish, though dark color (No. 19839, Carnegie Mus., Beaverton, Oregon, June 28, 1884), with nearly all the light markings buff, ochraceous, or tawny, 
very closely resembling the adult male of Chordeiles virginianus henryi; or even to a lighter brown, very much mottled (No.6819, J. Grinnell, Bluff Lake, San Bernardino Mountains, California, July 22, 1905), like the male of Chordeiles virginianus howelli.

As in Chordeiles virginianus virginianus, there is little or no geographical variation in this race. Breeding birds from southern California seem to be practically identical in both color and size with those from northern California, Idaho, western Montana, and other parts of the breeding range. Breeding birds from Nevada seem to be all Chordeiles v. hesperis, and identical with California specimens. One breeding example from the Hood River, Oregon (No. 156571, U.S.N.M., June 21, 1897), looks like Chordeiles virginianus virginianus; but others from North Dalles and Fort Steilacoom, Washington, from Heppner and the Joln Day River, Oregon, are surely Chordeiles $v$. hesperis; and while all the breeding birds available from Oregon and southern Washington are somewhat intermediate between $C$. v. virginianus and $C . v$. hesperis, they are much nearer the latter. A single specimen from the Milk River, at latitude $49^{\circ}$, Montana (No. 676t6, U.S.N.M., July 24, 1874), others from the Sun River and elsewhere in western and central Montana, as well as southern Idaho, are practically indistinguishable from California examples of Chordeiles virginianus hesperis. One half-grown bird in juvenal plumage from the Upper Geyser Basin, Yellowstone National Park, northwestern Wyoming (No. 62256, U.S.N.M., Aug. 20, 1872 ), is apparently the present form, being much too grayish for Chordeiles virginianus howelli, ${ }^{1}$ and too dark for Chordeiles virginianus sennetti. Breeding birds from Trail, southeastern British Columbia, close to the boundary of the State of Washington, verge toward Chordeiles virginianus virginianus, but are decidedly nearer Chordeiles $v$. hesperis. A series of breeding specimens from Maple Creek, southwestern Saskatchewan, and two individuals from Indian Head, Saskatchewan, incline somewhat toward Chordeiles v. sennetti, but are clearly the present form. Average measurements of breeding specimens from different parts of the range compare as follows:

\begin{tabular}{|c|c|c|c|c|c|}
\hline Localities. & TVing. & Tail. & $\begin{array}{l}\text { Exposed } \\
\text { culmen. }\end{array}$ & Tarsus. & $\begin{array}{c}\text { Middle } \\
\text { toe. }\end{array}$ \\
\hline Five males, from southern California.. & $\begin{array}{c}m m \text {. } \\
200\end{array}$ & $\begin{array}{c}m m . \\
113.5\end{array}$ & $\begin{array}{r}m m \\
7.2\end{array}$ & $\begin{array}{c}m m . \\
14.3\end{array}$ & $\begin{array}{l}m m_{1} \\
14.7\end{array}$ \\
\hline Five males, from Oregon and Montana.. & 200 & 112.2 & 6.7 & 14.4 & 14.8 \\
\hline 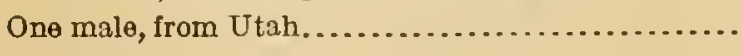 & 195 & 107.5 & 6.9 & 15 & $16^{\circ}$ \\
\hline Five females, from southern California........ & 194.1 & 112.5 & 6.9 & 14 & 15 \\
\hline Five females, from Oregon and Idaho.......... & 195.6 & 111.9 & 7 & 15 & 15.6 \\
\hline 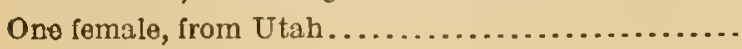 & 187 & 108 & 6.6 & 14.5 & 16.3 \\
\hline
\end{tabular}


Like Chordeites virginianus virginianus, this nighthawk lingers late in the spring south of its breeding range. A single typical male taken at Johnson Lake, Valley County, Montana, June 3, 1910, and another obtained at Saratoga, southeastern Wyoming, June 7, 1911, are evidently both but transients. So are also one taken by Alex Wetmore at Greybull, in Bighorn County, central northern Wyoming, June 14, 1910, and another at the same locality on June 15 of the same year, for the breeding bird of this region is Chordeiles virginianus howelli; and, furthermore, $\mathrm{Mr}$. Wetmore assures us that the species had first arrived in this valley only a few days previous, and appeared to be on the move. Likewise the autumn migration begins very early, sometimes, at least, by the middle of July, thus before the breeding season is over, as the following records of practically typical specimens indicate: One taken, July 14, 1909, at Winslow, Arizona, by C. Birdseye; one, August 3, 1904, at Tres Piedras, New Mexico; one, August 11, 1902, in the Huachuca Mountains, Arizona, by H. S. Swarth; one, August 18, 1909, at Tuba, Arizona, by E. W. Nelson; and another, September 1, 1908, in Buckskin Valley, Iron County, Utah, by W. H. Osgood.

It has been reported from Poway, San Diego County, California, during migration, but apparently not certainly from Lower California. Three specimens collected by Dr. C. W. Richmond on the Escondido River, 50 miles above Bluefields, Nicaragua (No. 128370, U.S.N.M., adult male, Sept. 17, 1892; No. 128371, U.S.N.M., adult male, Sept. 17, 1892; and No. 128373, juvenal male, Oct. 28, 1892), are apparently typical Chordeiles virginianus hesperis. The last one (No. 128373) is the example mentioned by G. K. Cherrie ${ }^{1}$ as like the type of his new race, Chordeiles virginianus aserriensis, but darker. An adult female (No. 27101, Field Mus.) from Miravalles, Costa Rica, is certainly Chordeiles v. hesperis, although M. A. Carriker, $\mathrm{jr}$., has recorded it as Chordeites virginianus virginianus. ${ }^{2}$

This nighthawk breeds chiefly during June and July, sometimes as early as May 24; at Big Stick Lake, near Maple Creek, Siskatchewan, Dr. L. B. Bishop found eggs on July 19, 1906. According to Joseph Grinnell it breeds chiefly in the Canadian Zone, though also in the upper part of the Transition Zone, in the San Bernardino. Mountains of southern California. In other localities, however, it nests regularly all through the Transition Zone and also in the Upper Austral Zone.

Specimens examined.-Specimens to the number of 120 have been seen, from the localities in the subjoined list:

Alberta.-Many Island Lake, near Walsh (July 13, 1906).

British Columbia.-Trail (June 13, 14, and 16, 1902). 
Saskatchewan.-Indian Head (June 18, 1892) ; Maple Creek (June 14, 1905; June 5, 1906; July 4 and 30, 1906); Hay Creek, near Maple Creek (July 6, 1906) ; Big Stick Lake, near Maple Creek (July 19, 1906).

Arizona.-Tuba (Aug. 18, 1909); Winslow (July 14, 1909); Huachuca Mountains (Aug. 11, 1902).

California.-Fish Creek, San Bernardino Mountains, 9,000 feet altitude (June 15, 1905); Bluff Lake, San Bernardino Mountains, 7,500 feet altitude (July 21, 22, 24, and 25, 1905) ; Sugarloaf Mountain, San Bernardino Mountains, 7,500 feet altitude (Aug. 23, 1905); Bear Lake, San Bernardino Mountains, 6,700 feet altitude (July 30, $1905)$; South Fork of Santa Ana River, San Bernardino Mountains (6,200 feet altitude, July 2, 4, 7, and 8, $1906 ; 7,000$ feet altitude, June 27, 1905); Troy Meadows, Sierra Nevada (Aug. 2, 1911); Trout Creek, Sierra Nevada, Tulare County (3,000 feet altitude, July 28, 1911; 6,000 feet altitude, July 30 and 31, 1911) ; Jackass Meadow, Sierra Nevada, Tulare County, 7,750 feet altitude (July 30, 1911); Parker Creek, Warner Mountains, 5,500 feet altitude (June 22, 1910); Squaw Mountain, Warner Mountains (July 20, 1910); Coppervale, Lassen County (June 15, 1906) ; Millford, Honey Lake (June 18, 1906) : Quincy (June 21, 1889); Redding (June 17, 1883); Lake City (June 11, 1896) ; Mount Shasta (Aug. 4, 1883; July 29 and 31, 1904); Blue Canyon (June 9, 1882); Tulare Valley; Cisco (June 30, 1885) ; Furnace Creek, Death Valley (June 19, 1891).

Colorado.-Estes Park (Aug. 3 and 10, 1893).

Idaho.-Pocatello (June 10, 1911) ; Birch Creek (Aug. 4, 1890); Big Butte (July 9, 1890); Arco (nestling, July 25, 1890); Nampa.

Kansas.-Hamilton (Sept. 10, 1913).

Montana.-Milk River at $49^{\circ}$ north latitude (July 24, 1874) ; Sun River (Aug. 10 and 24, 1867) ; Great Falls (July 20, 1890) ; Johnson Lake, Valley County (June 3, 1910) ; Bozeman (Aug. 9, 1888) ; Corvallis (July 7, 1910); Gold Creek, Powell County, 5,000 feet altitude (Aug. 26, 1910).

Nevada.-Big Creek Ranch at base of Pine Forest Mountains (June 16, 1909) ; Pyramid Lake (June 23, 1893; July 3, 1903) ; Virgin Valley, Humboldt County (June 3, 1909); Gardnerville (July 13, 1898) ; East Humboldt Mts. (Aug. 4, 1868) ; Carson (June 18, 1881).

New Mexico.-Tres Piedras (Aug. 3, 1904, J. H. Gaut).

Oregon.-Newport (June 16, 1901); Adel, Lake County (June 20, 1896) ; John Day River (June 21, 1899); Beaverton (June 28, 1884; June 21, 1890; July 3, 1890) ; Fort Klamath (July 25, 1883) ; Heppner (June 10, 1896); Lake Alvord (July 31, 1896); Hood River (June 21, 1897) ; Astoria (nestling, July 19, 1897) ; Crooked River, 20 miles southeast of Prineville (June 28, 1896); 7 miles northwest of Corvallis (July 22, 1898) ; 1 mile southeast of Corvallis (July 4, 1899). 
Texas.-Brownwood (Aug. 25, 1888).

Utah.-Buckskin Valley, Iron County (two specimens, Sept. 1, 1908) ; Fairfield (June 21 and 27, 1890).

Washington.-North Dalles (Rockland) (July 3, 1897); Fort Steilacoom, Puget Sound (July 16, 1858).

Wyoming.-Stinking Creek (=Shoshone River) (June, 1860); Greybull (June 14 and 15, 1910); Saratoga (June 7, 1911); Upper Geyser Basin, Yellowstone National Park (Aug. 20, 1872).

Campeche.-La Tuxpana (Oct. 4, 1912).

Nicaragua.-Escondido River, 50 miles from Bluefields (Oct. 28, 1892 ; Sept. 17, 1892).

Measurements of specimens of Chordeiles virginianus hesperis.

\begin{tabular}{|c|c|c|c|c|c|c|c|c|c|}
\hline Museum and No. & Sex. & Loeality. & Date. & Collector. & $\stackrel{30}{a}$ & हैं & 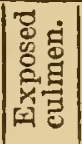 & 蛋 & $\varliminf_{0}^{0}$ \\
\hline J. Grinnell 6917 1... & Míale ${ }^{2}$. & $\begin{array}{l}\text { Bear Lake }(6,700 \\
\text { feet alt.), San } \\
\text { Bernardino } \\
\text { Mountains, Cal. }\end{array}$ & July 30,1905 & J. Grinnell. & $\begin{array}{l}m m . \\
205\end{array}$ & $\left|\begin{array}{c}m m \\
116.5\end{array}\right|$ & $\begin{array}{c}m m \\
8\end{array}$ & $\begin{array}{c}m m \\
14.5\end{array} \mid$ & $\begin{array}{l}m m \\
15\end{array}$ \\
\hline J. Grinnell 6467 I.. & ..do. & $\begin{array}{l}\text { Fish Creek (9,000 } \\
\text { feet alt.), San } \\
\text { Ber nardino } \\
\text { Mountains, Cal. }\end{array}$ & June 15,1905 & ....do.. & 198 & 113 & 7 & 14.5 & 15 \\
\hline J. Grinnell $68421 .$. & & $\begin{array}{l}\text { Bluff Lake (7,500 } \\
\text { feet alt.), San } \\
\text { Bernardino } \\
\text { Mountains, Cal. }\end{array}$ & July 24,1905 & . . do. & 191.5 & 107 & 6.5 & 13.8 & 14 \\
\hline Grinnell $6860^{1} \ldots$ & ... do. & ..... do... & July 25,1905 & ...do. & 207 & 120 & 7.5 & 14.2 & 15 \\
\hline $\begin{array}{l}\text { Mus. Vert. Zool. } \\
19910^{1} \text {. }\end{array}$ & ... do & $\begin{array}{c}\text { Trout Creek (3,000 } \\
\text { feet alt.), Sierra } \\
\text { Nevada Moun- } \\
\text { tains, T u lare } \\
\text { County, Cal. } \\
\text { Newport, Oreg... }\end{array}$ & June 16, 1901 & & 198.5 & 111 & 70 & 14.5 & 14.5 \\
\hline Gri & & New & June 16,1901 & B. J. Breth- & 211 & 118.5 & 6.2 & 15.2 & 15.2 \\
\hline $\begin{array}{l}\text { Mus. Vert. Zool. } \\
\text { S561.1 }\end{array}$ & ... do & $\begin{array}{l}\text { John Day River, } \\
\text { Oreg. }\end{array}$ & June 21,1899 & Loyo Miller. & 205 & 115 & 6.6 & 14 & 14 \\
\hline Carnegio Mus. & . do do & Beaverton, Oreg. - & June 21,1890 & $\begin{array}{l}\text { A. W. An- } \\
\text { thony. }\end{array}$ & 200 & $112.5 \mid$ & 8 & 14.5 & 5.5 \\
\hline - 1403921. & ... do & Hepp & Jun & E. A. & 201 & 108 & 6 & 14.1 & 5 \\
\hline $\begin{array}{l}28076^{1} \\
0394 \ldots\end{array}$ & $\begin{array}{ll}\text {.do } \\
\text { do }\end{array}$ & $\begin{array}{l}\text { Corv } \\
\text { Fair }\end{array}$ & Jul & B. B & 183 & 107 & 6.5 & 14 & 6 \\
\hline $\begin{array}{l}\text { Mus. Vert. Zool. } \\
19911.1\end{array}$ & Female. & $\begin{array}{l}\text { Trout Creek }(6,000 \\
\text { feet alt. }) \text {, Sierra }\end{array}$ & $\begin{array}{l}\text { June } 21,1890 \\
\text { July } 30,1911\end{array}$ & J. GI & $\begin{array}{l}195 \\
187\end{array}$ & $\left|\begin{array}{l}107.5 \\
110\end{array}\right|$ & $\begin{array}{l}6.9 \\
6.5\end{array}$ & $\begin{array}{l}15 \\
14.2\end{array}$ & $\begin{array}{l}16 \\
15\end{array}$ \\
\hline $\begin{array}{l}\text { Mus, Vert. Zool. } \\
\text { 19912.1 }\end{array}$ & $d 0$ & $\begin{array}{c}\text { Nerada Moun- } \\
\text { tains, T ulare } \\
\text { County, Cal. } \\
\ldots . \text {. do.............. }\end{array}$ & .do...... & & 193 & 113 & 7 & 14.5 & 16 \\
\hline 5401 & ...do & $\begin{array}{c}\text { South Fork Santa } \\
\text { AnaRiver(6,200 } \\
\text { feet alt.), San } \\
\text { Bernardino } \\
\text { Mountains, Cal. }\end{array}$ & July 4,1906 & ....do. & 198 & 119 & 7 & 14.2 & 15 \\
\hline $\begin{array}{l}\text { J. Grinnell } 7549 \text { 1... } \\
\text { J. Grinnell } 6819 \text { 1.. }\end{array}$ & $\begin{array}{l}\ldots \text { do } \\
\ldots \text { do }\end{array}$ & Bluff Lake cr.500 & July 2, 1906 & do & 196 & 112 & 6.5 & 13 & 15 \\
\hline & ...do & $\begin{array}{l}\text { Bluit Lake (7,500 } \\
\text { feet alt.), San } \\
\text { Bernardino } \\
\text { Mountains, Cal. }\end{array}$ & July 22, & & 196.5 & 108.5 & 7.5 & 14 & 2 \\
\hline $\begin{array}{l}\text { Carnegie Mus. } \\
19841.1\end{array}$ & & & & $\begin{array}{l}\text { A. W. An- } \\
\text { thony. }\end{array}$ & 191 & $|110.5|$ & 7.3 & 14.8 & 15.5 \\
\hline eg i o Mus. & $d n_{0}$ & $d n$ & June 28,1884 & & 20 & 113 & 8 & 15.2 & 6 \\
\hline U.S.N.M. 1403931 . & . do & $\begin{array}{l}\text { Crooked River, } 20 \\
\text { miles southeast } \\
\text { of Prineville, } \\
\text { Oreg. }\end{array}$ & June 28,1896 & V. Bai & 197.5 & 115 & 6.9 & 15.2 & 16 \\
\hline $\begin{array}{l}1422241 \\
1404071 .\end{array}$ & ... do & $\begin{array}{l}\text { Big Butte, Idaho. } \\
\text { do }\end{array}$ & $\begin{array}{c}\text { July } 19,1890 \\
\ldots \ldots \text { do...... }\end{array}$ & $\begin{array}{l}\text { C.P.Streator } \\
\ldots . \text { do....... }\end{array}$ & \begin{tabular}{|l|}
203 \\
194.5
\end{tabular} \mid & $\begin{array}{l}116 \\
105\end{array}$ & $\begin{array}{l}6.8 \\
6.1\end{array}$ & $\begin{array}{l}14.8 \\
15\end{array}$ & 8 \\
\hline & 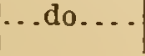 & Fairfield, Utah... & June 27,1890 & V. Bailey & 157 & & 6.6 & 14.5 & 3 \\
\hline
\end{tabular}




\section{CHORDEILES VIRGINIANUS SENNETTI Coues.}

[Chordiles popetue] Sennetti Couss, Auk, vol. 5, Jamuary, 1SSS, p. 37 (50 miles west of Pembina [sic], North Dakota; and Wharton County, Texas).

Chars. subsp.-Resembling Chordeiles virginianus hesperis, but upper surface of male lighter and more grayish, i. e., the dark brown ground color lighter and more grayish, the light markings finer, more numerous, and paler, more grayish or whitish (less ochraceous); general tone of lower surface lighter, the dark anterior portions more grayish, the bars on posterior portion narrower, sometimes interrupted.

Measurements.-Male: Total length (in flesh), 212.6-247.6 (average, 231.6) mm. ; ${ }^{1}$ extent of wing, 412.8-590.6 (541). ${ }^{1}$

Female: Weight, 2 ounces 4 drams to 3 ounces 3 drams avoirdupois $^{2}$ (average, 2 ounces 13.3 drams).

Male: ${ }^{3}$ Wing, 186-213 (average, 198.3) mm.; tail, 101.5-112.5 (109.1); exposed culmen, 6.0-7.2 (6.9); tarsus, 13.5-15.8 (14.6); middle toe, 13.9-16 (15.3).

Female: ${ }^{4}$ Wing, 175-201 (189.5) mm.; tail, 102.5-115 (108); exposed culmen, 6.0-7.5 (6.5); tarsus, 13.8-15.3 (14.7); middle toe, 14-16 (14.9).

Type-locality.-Fifty miles west of the Pembina Mountains, in central northern North Dakota.

Geographical distribution.-Central northern United States, probably south in winter to South America; breeds in the Upper Austral and Transition zones, north to Pembina, to Towner County, and old Fort Union, northern North Dakota ; and Strater, northeastern Montana; west to Strater, Darnall's Ranch in Dawson County, and Fort Keogh, eastern Montana; and Uva, southeastern Wyoming; south to Uva, southeastern Wyoming; Rosebud, central southern South Dakota; Thomas County and Antelope County, north central Nebraska; Sioux City and Dickinson County, northwestern Iowa; east to Dickinson County, northwestern Iowa; Madison, southwestern Minnesota; and Pembina, northeastern North Dakota. Migrates through Kansas and eastern Colorado, and probably Central America. Winters probably in South America.

Remarlis.-This is easily seen to be one of the palest races, and is characterized, particularly in the male, by the grayish cast of light and dark colors both above and below, as compared with the other forms. The broad light streaks on the nape, especially, are very light buff or even whitish, and the upper surface of the wings has much

\footnotetext{
1 Four specimens.

2 Three specimens.

3 Ten specimens, from South Dakota, Nortl Dakota, Minnesota, and Montana.

- Ten specimens, from South Dakota and North Dakota.
} 
light gray and whitish with a minimum of buff. The male of this subspecies is readily distinguishable from Chordeites virginianus virginianus by its much lighter upper surface, the dark ground color less blackish, more grayish brown, the light mottlings much more numerous, finer, paler, and less ochraceous (more whitish or grayish) ; and also by its lighter lower surface, the posterior portion white instead of more or less tinged with buff or cream color, and less heavily barred with klackish, and the dark brown of anterior portion more grayish.

The female is more brownish below on the dark areas than is the male, also more washed with buff on the posterior portion; above usually darker and with less white mottling, the dark areas slightly more brownish, the light markings duller, more brownish, or more tinged with buff or ochraceous (not so whitish), and thus not so sharply contrasted. She differs from the female of Chordeiles virginianus virginianus in much lighter, more grayish (less brownish) upper surface, with much more numerous light markings; and paler lower parts, the dark portions more grayish (less brownish), the light areas more whitish (less tawny or ochraceous), and posteriorly less heavily brown-barred. From the female of Chordeiles virginianus hesperis she may be distinguished above by the somewhat lighter, more grayish shade of the dark brown ground color, and more whitish (less ochraceous), and usually more numerous light markings, the cervical streaks particularly paler, less buffy; and below by her somewhat paler and more grayish general cast, and the less deeply buff-tinged and less heavily barred posterior portion.

The first autumn plumage is lighter above than that of any of the other races, so much so that no special comparison is necessary; the upper surface being of a pale silvery gray, finely vermiculated, and sometimes also spotted with black and dark brown-really a very beautiful bird. As in the adult there is, however, much individual variation; some specimens are much more coarsely vermiculated, and even blotched and streaked with black above; some examples have a pure gray cast, others have a decided tinge of buff both above and below.

The nestling is usually pure white or cream white below, and duller, buffy white, with dark gray markings above; but occasionally pale fawn color below, and fawn color with Prout's brown markings above.

Individual variation has about the same range in the female as in the male. The latter is normally pale above, with numerous light grayish or whitish mottlings, from which it varies in occasional examples to a bird much more extensively blackish above, with much less light mottling and practically not distinguishable from typical 
Chordeites virginianus hesperis. Such are No. 13473, L. B. Bishop, adult male, Stump Lake, North Dakota, August 4, 1905; and No. 26715, Academy of Natural Sciences of Philadelphia, adult female, Huron, South Dakota, July, 1881. Birds of this description may, however, almost always be separated from Chordeiles virginianus hesperis by their pale, lightly barred under surface. The other extreme is a bird which has the markings of the upper parts very whitish, numerous, and extensive (No. 26717, Acad. Nat. Sci. Phila., adult male, Huron, South Dakota, July, 1881). Another variation produces a bird in which most of the light markings on back, scapulars, pileum, and hind neck are buff, cream buff, or cream color (No. 19835, Carnegie Mus., adult male, Madison, Minnesota, June 4, 1891). In some examples the lower tail-coverts and the middle of abdomen are almost immaculate white. There is some variation also in the depth of the color and in the width of the dark brown bar's on the posterior lower parts. As may be seen from the table of measurements, this form varies greatly in size, apparently more so than some of the other races. A single adult female (No. 1960, collection of L. B. Bishop), from Towner County, North Dakota, taken June 11, 1895 , is very brownish, and ochraceous or buffy both above and below, and is practically indistinguishable in appearance from very typical female Chordeiles virginianus howelli, thus strikingly different from any of the females of Chordeiles virginianus sennetti examined. It is, of course, just possible that this individual wandered northward from the range of Chordeiles virginianus howelli, ${ }^{1}$ but it seems better to regard it as an abnormal variation of Chordeiles virginianus sennetti.

This subspecies has a more restricted distribution than most of the others. The birds from Huron, South Dakota, and from eastern South Dakota and eastern North Dakota in general are most typical, in that they carry to the extreme the characters of the subspecies; and the type of this race, from 50 miles west of the Pembina Mountains, is practically the same as these. Specimens representing the breeding bird of Dickinson County, Iowa, and Madison, western Minnesota, verge toward Chordeiles virginianus virginianus, but are much nearer the present race. Examples from Strater, and from Darnall's Ranch, Dawson County, in northeastern Montana, are darker above, and very close to Chordeiles virginianus hesperis, but are, as a whole, nearer Chordeiles v. sennetti. A single specimen (No. 171803, U.S.N.M., June 3, 1889) from Fort Keogh, central eastern Montana, seems to incline a little toward Chordeiles virginianus hovelli, ${ }^{1}$ in its more brownish and ochraceous colors above. Females from Towner County, North Dakota, are apparently darker on the upper surface than the females from farther south, but the males from the 
corresponding localities do not seem to differ. Two birds shot on Washington Creek, Kansas, September 12, 1908, identified and recorded ${ }^{1}$ by Alex Wetmore, constitute one of the two authentic records for Kansas. Strangely enough, however, Chordeiles virginianus sennetti has apparently not a single record for Texas, although it almost certainly migrates through this State; since all the alleged instances of its occurrence there, so far as we have been able to determine, prove to be misidentifications of Chordeiles virginianus howelli ${ }^{2}$ or Chordeiles virginianus aserriensis. ${ }^{3}$ Nothing definite is known concerning its winter home, but this is presumably South America.

This race, like most of the others, rears but one brood a yearin June or July. There are records of eggs from Miner County, South Dakota, as early as June 6 (1891) ; and from Towner County, North Dakota, as late as June 30 (1895); while we have seen nestlings from Devils Lake, taken on July 18 (1901).

The Sennett nighthawk was first described by Dr. Elliott Coues ${ }^{4}$ in the following language:

2. Sennetti, large, silvery grayish-white predominating above, the white below greatly in excess of the narrow. irregular or broken, dark bars, and little or no rufous anywhere. Hab. Dakota to Texas, in any treeless country. Types 65,490, Mus. Smiths. Inst., formerly 3301, Mus. E. C., 50 miles west of Pembina, Minn., July 16, 1873, and 4927, Coll. George B. Sennett, Wharton Co., Texas, May 27, 1857.

Each of the specimens mentioned as types bears on the back of its label this legend, in the handwriting of Doctor Cones: "A type of the species Elliott Cones." The first example, which is now in the United States National Museum, has commonly received the distinction of being the type, but its correct locality is not " 50 miles west of Pembina," as Coues and subsequent authors give it; but " 50 miles west of Pembina Mts.," as the original label, in Doctor Cones" own well-known chirography, shows. This specimen is an adult male in worn summer plumage, of large size-that is, as big as Chordeiles virginianus virginianus, and of pale gray coloration, like the breeding birds of North Dakota and South Dakota; in fact, a good representative of the race that passes current under the name Chordeiles virginianus sennetti. The alleged type specimen from Wharton County, Texas, which is now in the American Museum of Natural History, in New York, is, however, a typical breeding bird of the small, more buffy, though pale, form of southern Texas, which we hereinafter separate as Chordeiles virginianus aserriensis. ${ }^{3}$ Since this example does not, consequently, agree with the original diagnosis,

1 Condor, vol. 11, 1909, p. 159.

2 See p. 5 .

${ }^{3}$ See p. 71 .

- Auk, vol. 5, Jánuary, 1888, p. 37. ) 
and since the specimen first mentioned, from 50 miles west of the Pembina Mountains, does so agree, the latter must stand as the type.

Specimens examined.-Seventy-seven specimens have been available, from the localities that follow:

Colorado.-Barr (Aug. 8, 1910).

Iowa.-Dickinson County (June, 1881) ; 4 miles southeast of Boone (Oct. 27, 1898).

Kansas.-Burlington (October, 1891) ; Hamilton (Sept. 17, 1913). Minnesota.-Madison (May 25 and 28, 1891; July 4 and 18, 1891); Grant County (spring, 1877); Kimbrae (Sept. 13, 1897).

Montana.-Fort Keogh (June 3, 1889) ; Darnall's Ranch, Dawson County, 30 miles south of Glasgow (July 8, 1910) ; Strater, Valley County (July 16 and 18, 1910).

North Dakota.-Fort Union (July 1, 1843); 50 miles west of the Pembina Mountains (July 16, 1873); Fort Rice (June 18, 1873); Pembina (June 13, 1873-parent of eggs); Linton (June 27, 1912); Big Muddy Creek (July 2, 1873); Towner County (June 1, 1895; June 7, 1895; June 11, 1895 ; June 30, 1895; July 8, 1895; July 17, 1895; July 31, 1896) ; Rock Lake, Towner County (July 7, 1905); Devils Lake Indian Reservation (July 22, 1905); Tellers Bay, Devils Lake (July 18, 1901); Wolford, Pierce County (July 20, 1905); Turtle Mountain, Rolette County (July 6, 1902) ; Ottofy, Nelson County (June 19, 1905); Adler, Nelson County (July 31, 1902; Aug. 12, 1901) ; Stump Lake, Nelson County (June 22, 1905; July 21, 1902; July 26, 1902; Aug. 2, 1902; Aug. 4, 1905; Aug. 9, 1901; Aug. 14, 1905) ; Souris River (Sept. 3, 1873) ; Kenmare (July 15, 1913); Sentinel Butte (June 7, 1913) ; Glenullin (July 9, 1913); Bismarck.

South Dakota.-Huron (July, 1881); near Rosebud (Aug. 14, 1911) ; Missouri River 40 miles above Fort Pierre (June 30, 1856).

Wyoming.-Little Medicine (Aug. 4, 1899); Uva (July 6, 1909).

Ilcasurements of spocimens of Chordeiles virginianus sennetti.

\begin{tabular}{|c|c|c|c|c|c|c|c|c|c|}
\hline Museum and No. & Sex. & Locality. & Date. & Collector. & $\stackrel{9}{9}$ & हేं & 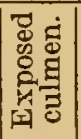 & 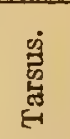 & 送 \\
\hline $\begin{array}{l}\text { A.N.S.Pbila.26720 } \\
\text { A. N. S. Phila. } 1\end{array}$ & $\begin{array}{l}{[\text { Male] ... }} \\
. . . \text { do..... }\end{array}$ & $\begin{array}{c}\text { Huron, S. Dak ... } \\
\ldots . . \text { do............. }\end{array}$ & $\begin{array}{c}\text { July }-, 1881 \\
\ldots . . . \mathrm{dn}, \ldots . . .\end{array}$ & $\begin{array}{c}\text { W.L.Abbott } \\
\text {.....do........ }\end{array}$ & $\begin{array}{l}m m \\
204 \\
213\end{array}$ & $\begin{array}{l}m m . \\
112.5 \\
112.5\end{array}$ & $\begin{array}{c}m m . \\
7 \\
7.1\end{array}$ & $\begin{array}{l}m m . \\
15.8 \\
15.1\end{array}$ & $\begin{array}{l}m m . \\
16 \\
15.9\end{array}$ \\
\hline${ }_{26718.1}^{26717.1}$ S. Phila. & $\ldots d$ & - & . & & 186 & 101.5 & 7.1 & 14.8 & 14.8 \\
\hline$\underset{438}{\operatorname{Am}} \underset{43.1}{\text { Mus. N. H. }}$ & Male & Fort Union,N.Dak & July 1,1843 & J.J.Audubon & 192.5 & 108 & 7 & 14.9 & 15.2 \\
\hline $\begin{array}{l}\text { U.S.N.M. } 171803^{1} \text {. } \\
\text { U.S.N.M. } 65294^{1} \text {. }\end{array}$ & $\begin{array}{l}\text {.. do..... } \\
\text {...do..... }\end{array}$ & $\begin{array}{l}\text { Fort Keogh,Mont. } \\
\text { Fort Rice,N.Dak. }\end{array}$ & $\begin{array}{l}\text { June 3,1889 } \\
\text { June 18,1873 }\end{array}$ & P.M.Thorne & $\begin{array}{l}199 \\
195\end{array}$ & $\begin{array}{l}111.5 \\
106.5\end{array}$ & $\begin{array}{l}7 \\
6\end{array}$ & $\begin{array}{l}13.5 \\
14\end{array}$ & $\begin{array}{l}15.5 \\
14.3\end{array}$ \\
\hline U.S.N.M. $65490^{1}$... & $\ldots$ do. ${ }^{2} \ldots$ & $\begin{array}{l}50 \text { miles west of } \\
\text { Pembina Moun- } \\
\text { tains, N. Dak. }\end{array}$ & July 16,1873 & $\mathrm{E} . \mathrm{Cou}$ & 194 & 111 & 7 & 14.9 & 16 \\
\hline $\begin{array}{l}\text { U.S.N.M. } 127570^{1} \text {. } \\
\text { Carnegie M u s. }\end{array}$ & ...do. & Madison, Minn.... & June 18, 1891 & A. Lano..... & 198 & 111 & 7 & 14.5 & 15.2 \\
\hline $\begin{array}{c}\text { Carnegie } \\
19834.1\end{array}$ II u s. & & .....do.............. & ..... do ....... & [A. La & 199 & 104.5 & 6.8 & 13.9 & 13.9 \\
\hline $\begin{array}{r}\text { Carnegie } \\
19835.1\end{array}$ M us. & ...do. & ...do. & June 4,1891 & .....do & 202 & 112 & 7.2 & 14.5 & 16 \\
\hline A. N. S. Phila. & [Female] & Huron, S. Dak . & July -, 1881 & W.L.A bbott & 189 & 104 & 6.8 & 14.8 & 15 \\
\hline
\end{tabular}

1 Used In measurement averages on p. 52.

2 Type. 
Measurements of specimens of Chordeiles virginianus sennetti-Continued.

\begin{tabular}{|c|c|c|c|c|c|c|c|c|c|}
\hline Museum and No. & Sex. & Locality. & Date. & Collector. & $\stackrel{80}{: 00}$ & 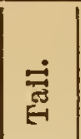 & 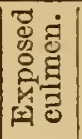 & 总 & $\mid$\begin{tabular}{l}
0 \\
0 \\
0 \\
0 \\
\hdashline
\end{tabular} \\
\hline A. N. S. Phila. & [Female] & Huron, S. Dak. & July,- 1881 & W.L.Abbott & $\begin{array}{c}m m \\
1 S 3\end{array}$ & $\begin{array}{l}m m \\
107\end{array}$ & $\begin{array}{r}m m . \\
6.9\end{array}$ & $\begin{array}{c}m m . \dot{ } \\
13.8\end{array} \mid$ & $\begin{array}{l}m m \\
14\end{array}$ \\
\hline A. N. S. Phila. & Female. & Pembina, N. Dak. & June 13,1873 & E. Coue & 192.5 & 110 & 6.1 & 15 & 16 \\
\hline L. B. Bishop 7882 & .. do. & Adler, Nelson Co., & July 31,1902 & L. B. Bishop & 198.5 & 110.5 & 6.5 & 14.5 & 15 \\
\hline L.B.Bishop $13084^{1}$ & .do. & Stump Lake, Nel- & June 22, 1905 & ..do & 197 & 107 & 6 & 15 & 15.8 \\
\hline $\begin{array}{l}\text { L.B.Bishop } 7797 \\
\text { L.B.Bishop } 7798 \\
\text { L.B.Bishop } 6248 \\
\text { L.B.Bishop } 2030\end{array}$ & $\begin{array}{l}\text {-. do. } \\
\text {-..do. }\end{array}$ & 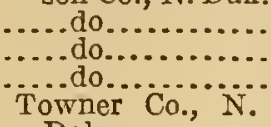 & $\begin{array}{c}\text { July 26, } 1902 \\
\ldots \ldots \text {...do...... } \\
\text { Aug. 9, } 1901^{\circ} \\
\text { June } 30,1895\end{array}$ & .....do.. & $\begin{array}{l}177 \\
194 \\
201 \\
187\end{array}$ & $\begin{array}{l}102.5 \\
111 \\
115 \\
109\end{array} \mid$ & $\begin{array}{l}6.5 \\
6 \\
7 \\
6\end{array}$ & $\begin{array}{l}14 \\
15 \\
15.3 \\
15\end{array}$ & \begin{tabular}{|l}
14 \\
14.2 \\
15.2 \\
15
\end{tabular} \\
\hline L.B.Bishop 2952 I. & do. & & July 31,1896 & E.T. Judd & 175. & 104 & 7.5 & 14.8 & 15 \\
\hline
\end{tabular}

CHORDEILES VIRGINIANUS HOWELLI, ${ }^{2}$ new subspecies.

Chars. subsp.-Somewhat like Chordeiles virginianus sennetti, but male with upper parts more rufescent and somewhat paler, the dark brown ground color more rufescent, less grayish, and the light markings much more buffy or ochraceous; posterior lower partis more buffy, and the anterior dark brown areas more rufescent.

Description.-Type, adult male, No. 186731, U.S.N.M.; Lipscomb, Texas, June 25, 1903, Arthur H. Howell; original number, 105. Upper parts brown, between hair brown and clove brown, much spotted, mottled, and irregularly and brokenly barred, so that comparatively little of the ground color remains, with brownish white, light brown, buff, and ochraceous, least numerously on the pileum, most coarsely on the scapulars, and in the form of broad irregular and broken bars on the upper tail-coverts, and of a more or less observable collar of broad buff and ochraceous buff streaks on the hind neck; tail brown like the ground color of upper parts, crossed by about 7 wide, irregular and broken bars, one of which is terminal on only the middle pair of rectrices, these bars light hair brown or whitish, and widest on the middle pair of feathers, and all the rectrices but the two middle ones with a broad subterminal band of pure white; wing-quills brown like the tail, the outer five primaries crossed by a very broad band of pure white posteriorly to the tip of the ninth primary (counting from the outermost); secondaries and inner primaries tipped with brownish white; outer half or more of the inner webs of secondaries and inner primaries with cream white or buff bars, those on primaries broken or obsolescent; the tertials mottled with light brown, brownish white, and buffy white, in the form of broad but much broken and obsolescent bars; superior wing-

1 Used in measurement averages on p. 52.

2 Named for my friend Mr. Arthur H. Howell, who collected the type specimen,

$13732^{\circ}-$ Bull. $86-14-5$ 
coverts brown like the wing-quills, the primary coverts with a few buff and brownish white spots, chiefly on inner webs, the others heavily spotted and mottled, in many places confluently, with cream white, brownish white, and buff, these light markings forming on the median and distal lesser coverts a conspicuous and almost solid patch; moustachial stripe and sides of head and neck dark brown like the ground color of upper parts, the subocular, postocular, and auricular regions, together with the sides of neck, conspicuously, the last-mentioned broadly, streaked with ochraceous buff and tawny ochraceous, the moustachial stripe much spotted and streaked with ochraceous buff and light tawny ochraceous; an ill-defined superciliary stripe consisting of spots and streaks of whitish and buffy, posteriorly confluent with the light streaks on the side of the neck and on the cervix; lores mostly white, somewhat mixed, particularly on lower portion, with fine markings of dark brown; chin white, washed with buff, finely streaked, and somewhat spotted with dark brown; broad gular crescent pure white; jugulum and upper breast sepia, the former heavily spotted with tawny, the latter spotted, streaked, and barred with creamy white, brownish white, cream buff, and buff; remainder of inferior surface cream white, barred with sepia, most thickly on lower breast, least thickly but more widely on lower tail-coverts; under wing-coverts dark brown like the wings, heavily barred with white, cream white, buff, and ochraceous buff; axillars cream color, barred with dark brown; edge of wing along the alula white.

Iris dark brown; bill black; feet gray.

Measurements.-Male: Total length (in flesh), $235 \mathrm{~mm}$. ; $^{1}$ extent of wing, 565.2. ${ }^{1}$

Female: Total length (in flesh), 228.6-254 (average, 239.3) ; ${ }^{2}$ extent of wing, 558.8-590.6 (577.9). ${ }^{2}$

Male: ${ }^{3}$ Wing, 192.5-211 (average, 200) mm.; tail, 105-121 (112.3); exposed culmen, 5.9-7.0 (6.3) ; tarsus, 13-15.2 (14.3); middle toe, $14.2-15.5 \cdot(14.9)$.

Female: ${ }^{*}$ Wing, 185-203.5 (193.4) mm.; tail, 104-122.5 (112.8); exposed culmen, 6.5-7.2 (6.9); tarsus, $13-14.8$ (14.2); middle toe, 14.6-16 (15.3).

Type locality.-Lipscomb, northwestern 'Texas.

Geographical distribution.-Central portion of western United States; south in migration through Central America, probably to South America. Breeds in the Lower Austral, Upper Austral, Transition, and Canadian zones, north to the Republican River,

1 One specimen.

2 Three specimens.

${ }^{3}$ Ten specimens, from Kansas, Texas, Colorado, Utah, and Wyoming.

- Ten specimens, from Iiansas, Colorado, Wyoming, New Mexico, and Utab. 
central northern Kansas; southwestern Nebraska; Wray and Loveland, northeastern Colorado; Laramie Peak, southeastern Wyoming; Greybull and Germania in Bighorn County, northwestern Wyoming; west to Germania and Fort Bridger, western Wyoming; and Parley's Park, Wasatch Mountains, central northern Utah; south to the Uinta Mountains, northeastern Utah; Grand Junction, central western Colorado; Twin Lakes, central Colorado; the Rio Grande and Trinidad, central southern Colorado; Sierra Grande and Cuervo, northeastern New Mexico; Hereford and Lamb County, northwestern Texas; San Angelo and Giddings, central Texas; east to Giddings, central Texas; Terrell and Bonham, central northern Texas; Lawton, central southern Oklahoma ; Cairo, Hamilton, Turkey Creek, and the Republican River, middle Kansas. Migrates through eastern Mexico and Central America, and casually east to Grant County, southwestern Minnesota, and Warsaw, western Illinois. Winters probably in South America.

Remarks.-The male of this new race differs from that of Chordeiles vinginianus henryi in lighter upper surface, particularly on the scapulars and tertials, the dark areas being more brownish (less blackish) and the light markings finer and usually much less deeply tawny or ochraceots; and in the lighter lower surface, which is less deeply buffy on posterior portion and less rufescent on the anterior part. From Chordeiles virginianus hesperis he may readily be distinguished by his much paler upper parts, the dark brown areas less blackish, the light mottlings much more numerous; and by the paler, anteriorly less rufescent, posteriorly more buffy, and more narrowly or brokenly barred lower surface. He is so very different from Chordeiles virginianus virginianus by reason of his much paler, more brownish, and much more numerously ochraceous- and buffy-marked upper parts; lighter, less blackish (more brownish) anterior lower surface; and lighter, less heavily barred breast and abdomen, that he is distinguishable almost at a glance.

The female is usually more brownish, decidedly more mottled with ochraceous on the upper parts, and much more buffy below than is the male. This makes the female more closely resemble the female of Chordeiles virginianus henryi than the male does the male of Chordeiles $v$. henryi, but she nevertheless is separable from the female of Chordeiles $v$. henryi by her lighter, more rufescent (less blackish) brown upper parts, with paler, usually finer and more numerous markings; and by the lighter jugulum (both as regards the ground color and the tawny and buff markings), throat, and posterior lower parts. From the female of Chordeiles virginianus sennetti she unay be distinguished on the upper parts by her much more brownish (less grayish) and lighter ground color, and much more ochraceous light markings; and below by the more rufescent, 
less grayish, hue of the dark brown areas, the more ochraceous, tawny, or buff light parts, and the rather more weakly and brokenly barred abdomen. Compared with female Chordeiles virginianus hesperis, she is paler above, the dark areas being more brownish (less blackish or grayish), the light markings more numerous and more generally tawny or ochraceous (less whitish), so that the general effect is more rufescent; she is also lighter below, the dark areas, particularly the jugulum, more rufescent, the throat and other light portions anteriorly averaging more deeply tawny or ochraceous, posteriorly nearly always much more deeply and extensively buff, with lighter dusky bars.

The first autumn plumage is somewhat similar to that of Chordeiles virginianus hesperis, but is very much lighter above-is, in fact, the lightest of all the races excepting Chordeiles virginianus sennettimore extensively mottled, the dark markings greatly reduced; also on the light areas more ochraceous or buffy, and on the dark portions more brownish (less blackish). It differs from the first autumn plumage of Chordeiles virginianus sennetti in its darker, more ochraceous or buffy upper parts, and less finely and closely vermiculated throat and jugulum.

Individual variation in this subspecies is about as great as in Chordeiles virginianus hesperis. The normal coloration of the male is fairly represented by the type described above. Occasionally the upper parts are much more extensively light-mottled, so much so that the dark ground color is almost obscured, as in No. 38316, U.S.N.M., adult male, Laramie Peak, Wyoming, June 9, 1864. The other extreme shows in No. 43846, Amer. Mus. Nat. Hist., adult male, Fort Bridger, Wyoming, June 22, 1858, in which the upper parts are much less heavily mottled, and the light markings more whitish, pale brownish or buffy (less ochraceous), thus giving the center of the back and the upper surface generally a more blackish aspect. Such birds are much like some specimens of Chordeiles virginianus hesperis, but are distinguishable by their more brownish cast above, and by their more creamy or buffy posterior lower parts. Rarely, as in No. 43531, Mus. Comp. Zoöl., adult male, Fort Bridger, Wyoming, June 22, 1858, the light markings of upper surface are more whitish, in which case the bird very much resembles Chordeiles virginianus sennetti; but the more brownish upper parts and more creamy or buffy ventral surface will serve to distinguish such specimens. The ground color of the posterior lower parts in the male is occasionally almost pure white, usually cream color or buff, sometimes cream buff. The female varies even much more than the male. One extreme is observable in specimens such as No. 166920, U.S.N.M., adult female, Henrietta, Texas, July 30, 1900, and No. 43530, Mus. Comp. Zoöl., 
Fort Bridger, Wyoming, June 21, 1858, which have dark, dull, blackish brown upper parts, with but sparse ochraceous, whitish or dull light brown mottlings, especially on the back, in which respect they are somewhat like Chordeiles virginianus hesperis, though more brownish, and which have also the breast and jugulum mostly dark brown with some buff or ochraceous buff spots, and the posterior lower parts whitish or pale buff. The other extreme is to be seen in birds like No. 19078, U.S.N.M., adult female, Antelope Hills, 150 miles west of Fort Cobb, Oklahoma, June 7, 1860, and No. 94693, U.S.N.M., Colorado Springs, Colorado, June 24, 1883, in which the upper parts are, in general effect, very tawny, much as in Chordeiles virginianus henryi, though paler, with the light markings above numerous and all tawny or tawny ochraceous; the throat and jugulum are mostly tawny and tawny ochraceous; and the posterior lower surface deep buff.

That three well-defined subspecies have hitherto been included under the name Chordeiles virginianus henryi is shown very plainly by the material available for the present investigation. One of these, to which the name Chordeiles virginianus henryi ${ }^{1}$ is applicable, is a large, rather dark, very rufescent or tawny bird, and occupies, during the breeding season, the greater part of New Mexico and Arizona; another, a small, pale, and rather grayish bird, summers chiefly in southern Texas, and to this the name Chordeiles virginianus aserriensis ${ }^{2}$ seems to apply; while the third is the large, light-colored buffy or ochraceous race, which ranges in summer from Wyoming and Colorado to Kansas and central Texas, and which I have above named Chordeiles virginianus howelli.

The geographical area occupied by Chordeiles virginianus howelli lies between the ranges of Chordeiles virginianus hesperis and Chordeiles virginianus aserriensis, ${ }^{2}$ on the one hand, and between Chordeiles virginianus sennetti and Chordeiles virginianus henryi, on the other; and it is to a certain degree intermediate also in colors; but notwithstanding this, it presents, characters that are fairly uniform over practically all of its range, except, of course, along the very edges of its distribution, where it passes into the surrounding forms of the species; and it is, on the whole, as the subspecies of Chordeiles virginianus go, a readily recognizable race. Birds from Fort Hays and Cairo, in middle Kansas, are not different from those of Colorado and southern Wyoming; and those from the southern part of Colorado, in the Rio Grande Valley, seem to be just like those from other parts of the same State-

1 Chordeiles henryi Cassin, Illustr. Birds Cal., Texas, Ore., Brit, and Russ. Amer., vol. 1, 1855, p. 239 (Fort Vebster, N. Mex.).

2 Cherrie, Auk, $\nabla 01.13$, April, 1896, p. 136. See also p. 73. 
that is, typical. Specimens from Germania, Greybull, and other localities in northern Wyoming are darker above, thus rerging somewhat toward Chordeiles virginianus hesperis, though still much too pale and brownish above for that form. Examples from southeastern Wyoming show some tendency toward intergradation with Chordeiles virginianus sennetti. The few individuals from Henrietta in central northern Texas examined are in color typical Chordeiles virginianus howelli, but in size appear to be smaller, in this showing a close approach to Chordeiles virginianus aserriensis ${ }^{1}$ of southern Texas; but the small series and the worn and otherwise poor condition of the specimens may be responsible for at least part of the difierence. Birds which apparently represent the breeding form of Lee County, Texas, considerably farther south and near the known breeding range of Chordeiles virginianus aserriensis, ${ }^{1}$ are, however, larger, while those from northwestern Texas are of full size. The differences in size that obtain in birds from the various parts of the breeding range of the present race are observable in the following average measurements:

\begin{tabular}{|c|c|c|c|c|c|}
\hline Localities. & Wing. & Tail. & $\begin{array}{l}\text { Exposed } \\
\text { culmen. }\end{array}$ & Tarsus. & $\begin{array}{l}\text { Middle } \\
\text { toe. }\end{array}$ \\
\hline $\begin{array}{l}\text { Ten males, from Wyoming, Utah, Colorado, Kansas, } \\
\text { and northwestern Texas...................... }\end{array}$ & $\begin{array}{r}m m . \\
200\end{array}$ & $\begin{array}{l}m m . \\
112.3\end{array}$ & $\begin{array}{l}m m . \\
0.3\end{array}$ & $\begin{array}{l}m m . \\
14.3\end{array}$ & $\begin{array}{l}m m . \\
14.9\end{array}$ \\
\hline Two males, from central northern Texas..... & 186 & 104.3 & 7 & 14.5 & 14.8 \\
\hline $\begin{array}{l}\text { Ten females, from Wyoming, Utah, Kansas, north- } \\
\text { eastern New Mexico, and northeastern Colorado.. }\end{array}$ & 193.4 & 112.8 & 0.9 & 14.2 & 15.3 \\
\hline One female, from central southern Colorado.......... & 105 & 118 & 6.8 & 13.8 & 14.2 \\
\hline Two females, from central northern Texas.... & 180.3 & 104.5 & 7 & 14.3 & 14.6 \\
\hline
\end{tabular}

One adult male from Warsaw, Illinois (No. 98226, U.S.N.M.), taken, May 20, 1884, and another from Grant County, Minnesota (No. 81564, Amer. Mus. Nat. Hist.), collected in the spring of 1877, seem to be both practically typical Chordeiles virginianus howelli, though apparently far out of the normal migration route of this form, and thus of merely casual occurrence here. The present race undoubtedly migrates regularly through Mexico and Central America to South America, but there is only one certain record of its occurrence south of the United States: a single individual from the Escondido Rirer, in Nicaragua, 50 miles above Bluefields, taken, September 17, 1892, by Dr. Charles W. Richmond.

The specimen (No. 6696, U.S.N.M.) that Prof. Spencer F. Baird regarded as the type of Chordeiles virginianus homyi Cassin is still 
in the United States National Museum. The face of its label is as follows:

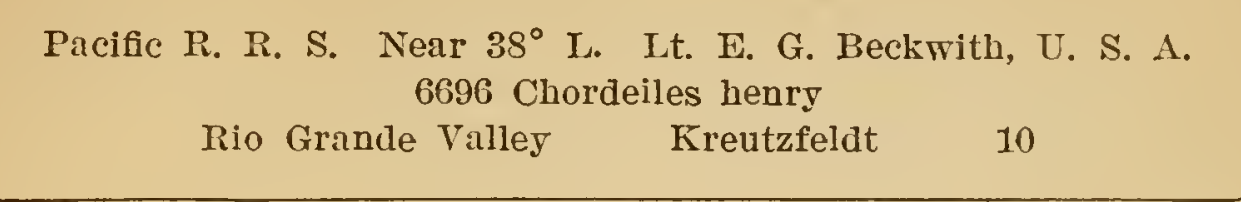

On the reverse side is the word "type" in Professor Baird's handwriting. This specimen was really taken in the San Luis Valley near $38^{\circ}$ north latitude, in central sonthern Colorado, where Lieutenant Beckwith's expedition is known to have traveled. Professor Baird recorded this specimen as the type of Chordeiles virginianus henryi, ${ }^{1}$ but, possibly by typographical error, gave it the wrong number (6690) $;^{1}$ and on the following page, ${ }^{2}$ in the "List of specimens," still another erroneous number (6698). This example is, however, not the real type of Chordeiles virginianus henryi, which came from Fort Webster, New Mexico, as we shall fully explain under that form, ${ }^{3}$ and Professor Baird in considering it such was evidently under misapprehension regarding the specimen on which $\mathrm{Mr}$. Cassin based his description of Chordeiles henryi. ${ }^{4}$ This supposed type is a female, in juvenal plumage, though full grown, with spotted throat and much mottled upper surface, and is undoubtedly an example of the present race, Chordeiles virginianus howelli.

Specimens examined.-I have examined 106 examples of this new race, from the localities below:

Colorado.-Loveland (July 23, 1895) ; Rio Grande (June 10, 13, and 15, 1873) ; Colorado Springs (June 24, 1873); Barr (June 4, 1910) ; Wray (May 21, 1909) ; San Luis Valley, near $38^{\circ}$ north latitude; Denver (July 7, 1888); mountains west of Denver.

Illinois.-Warsaw (May 20, 1884).

Kansas.-Fort Hays (June 3, 6, 7, 8, 10, and 12, 1871); Republican River (May 24 and 26, 1864); Republican River, 70 miles west of Fort Riley (June 30, 1857) ; Turkey Creek (July 21, 1857) ; Cairo (July 29, 1892) ; Hamilton (July 11 and 17, 1913; Sept. 10, 1913).

Minnesota.-Grant County (spring, 1877).

New Mexico.-Socorro (Aug. 15, 1909, E. A. Goldman); Cuervo (June 13, 1903, V. Bailey) ; Cantonment Burgwyn (Sept. 2, 1859); Sierra Grande (Aug. 17, 1903).

Oklahoma.-Antelope Hills, 150 miles west of Fort Cobb (June 7, 1860 ) ; Lawton (June 30, 1905); Chattanooga (July 4, 1905).

Texas.-Henrietta (July 30 and 31, 1900; Aug. 18, 1892; Aug. 1

${ }^{1}$ Rep. Explor. and Surv. R. R. Pac., rol. 9, 155s, p. 153.

2 Idem, p. 154.

${ }^{3}$ See pp. 68-69.

4 Cassin, Illustr. Birds Cal., Texas, Ore., Brit. and Russ. Amer., vol. 1, 1855, p. 239. 
and 3, 1900); Mobeetie (July 23, 1903); Corpus Christi (Oct. 22, 1909; May 21, 24, and 28, 1891; April 22, 1889; April 21 and 2t, 1891); San Antonio (April 16, 1889; May 31, 1891) ; Dallas; Lipscomb (June 25, 1903); Giddings (May 12 and 17, 1887; June 7. 1887) ; Lee County (May 26, 1888) ; Rio Grande City (May 1, 1889).

Utah.-Parley's Park, Wasatch Mountains (June 21, 1869; July 24, 1869; Aug. 13 and 16, 1869).

Wyoming.-Fort Bridger (June 16, 19, 21, and 22, 1858) ; Laramie Peak (June 4, 6, 9, and 21, 1864); Greybull (June 15 and 20,1910); La Bonte River (Aug. 8, 1858) ; Riverside (June 9, 1911); Bridger Pass (Aug. 13, 1856); Germania (June 23, 1910); Dry Creek, near Germania (June 22, 1910) ; Bitter Creek (Aug. 1, 1895) ; Laramic River (Aug. 27, 1876); Arvada (Aug. 21, 1913).

Campeche.-La Tuxpana (May 8, 1913).

Nicaragua.-Escondido River, 50 miles from Bluefields (Sept. 17, 1892).

Measurements of specimens of Chordeiles virginianus howelli.

\begin{tabular}{|c|c|c|c|c|c|c|c|c|c|}
\hline Museum and No. & Sex. & Locality. & Date. & Collector. & $\stackrel{\oplus 0}{E}$ & $\underset{\mathrm{F}}{\mathrm{E}}$ & 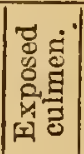 & 离 & 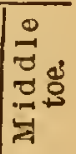 \\
\hline Am. Mus. N. H. & Male. & $\underset{\text { Frt B }}{\text { Foridger, }}$. & June 22,1858 & C. Drexler. & $\operatorname{mm}_{196}$ & $\begin{array}{c}m m \\
110.5\end{array} \mid$ & $\begin{array}{c}m m \\
6\end{array}$ & $\begin{array}{l}m m . \\
13.8\end{array}$ & $\begin{array}{l}m m \\
15.3\end{array}$ \\
\hline $\begin{array}{l}\text { U.S.N.M. } 108011 \text { 1. } \\
\text { U.S.N.M. } 585361 .\end{array}$ & $\ldots d d$ & $\begin{array}{r}\text { Parley's p a r k } \\
\text { Wasatch Moun- }\end{array}$ & $\begin{array}{l}\text { June } 19,1858 \\
\text { June 21,1869 }\end{array}$ & R...do....... & 211 & $\mid \begin{array}{l}121 \\
114.5\end{array}$ & $\begin{array}{l}6 \\
6.8\end{array}$ & $\begin{array}{l}14 \\
13\end{array}$ & $\begin{array}{l}15.5 \\
14.5\end{array}$ \\
\hline & & tain & Julp: & & 202.5 & 111 & 6.5 & 14.7 & 15.2 \\
\hline & $\ldots d$ & Lips & Juls & A. $\mathrm{H}_{\mathrm{dO}} \mathrm{H}$ & 203 & 111 & 6.3 & 15 & 15 \\
\hline & $\ldots d$ & , Colo... & July & E. A. Preble & 202 & 116.5 & 6 & 14.0 & 14. \\
\hline & .0 & Fort & $\mathrm{Ju}$ & $\ldots$ & 192.5 & 108.5 & 5.9 & 14 & 15 \\
\hline & & $\ldots . d$ & $\mathrm{Ju}$ & $\because 7$ & 197 & 110 & 6 & 14.2 & 14. \\
\hline & {$[$ Male]... } & $\begin{array}{l}\text { Cairo, Kans..... } \\
\text { Henrjetta, Tex... }\end{array}$ & $\begin{array}{l}\text { July } 29,1892 \\
\text { July } 31,1900\end{array}$ & $\begin{array}{l}\text { V. Bail } \\
\text { H. C. C }\end{array}$ & $\begin{array}{l}201 \\
181\end{array}$ & $\left|\begin{array}{l}115 \\
102.5\end{array}\right|$ & $\frac{7}{7}$ & $\begin{array}{l}15.2 \\
14.5\end{array}$ & $\begin{array}{l}15.2 \\
15\end{array}$ \\
\hline & & & & & 191 & 106 & 7 & 14.5 & 14. \\
\hline U.S & Fen & $\begin{array}{l}\text { Parley's } \mathrm{P} \text { a r } \mathrm{k}, \\
\text { Wasatch Moun- } \\
\text { tains, Utah. }\end{array}$ & $\mathrm{Aug}$ & R. Ridgway. & 194 & 117 & 6.5 & 13 & 10 \\
\hline U.S. & .. do & Grande, & Aug. 17, 1903 & А.Н.Howell. & 193 & 108 & 7.2 & 14.5 & 15.5 \\
\hline U.S.I & $\ldots d$ & Fort Bridger, & June 19,1858 & C. Dres & 193.5 & 5108.5 & 6.8 & 13 & 15.5 \\
\hline H. & s & & .....do. & & 5 & 122 & 6.8 & 14.8 & 14.8 \\
\hline & $d c$ & $d$ & Jun & [C. Dr & 200 & 117.5 & 7 & 1 & 15. \\
\hline & & Fort & Ju & $\because . . . d$ & 1185 & 108.5 & 72 & 14.8 & 15 \\
\hline & .. d & $\ldots . . . d$ & June & & 192.5 & 116 & 7 & 14.8 & 15 \\
\hline & & $\ldots 0$ & & & 186.5 & 104 & 7 & & 14. \\
\hline & $\ldots d$ & Wray & May 21,1909 & $\mathrm{M} . \mathrm{Ca}$ & 187.5 & 106 & 6.9 & 14.2 & 15. \\
\hline & $\begin{array}{c}\text { Fem } \\
\text { [ju }\end{array}$ & $\begin{array}{l}\text { Rio Grande Valley } \\
\text { [1. e., San Luis } \\
\text { Valley], near N. } \\
\text { Lat. } 38^{\circ} \text {, Colo. }\end{array}$ & ................. & $\begin{array}{l}\text { Mr. Kreuz- } \\
\text { feldt. }\end{array}$ & 195 & 118 & 6.8 & 13.8 & 14.2 \\
\hline & Female & Henr & July 30,1900 & H. C. Ober- & 186 & 106 & 6.5 & 15 & 15 \\
\hline U & dr & do & Aug. 1,1900 & & 71 & & 7.5 & 13.5 & 14.2 \\
\hline
\end{tabular}

1 Used in measurement arerages on p. $5 \mathrm{~S}$.

3 Type.

8 Supposed type of Chordeiles virginianus henryi (see pp. 62-63). 


\section{CHORDEILES VIRGINIANUS HENRYI CaSSIn.}

Chordeiles henryi Cassin, Illust. Birds Cal., Texas, Ore., Brit. and Russ. Amer., vol. 1, 1855, p. 239 (Fort Webster, N. Mex.).

Chars. subsp.-Similar to Chordeiles virginianus howelli, but upper surface, both ground color and markings, much darker, the latter more tawny and also coarser: lower parts posteriorly more buffy, anteriorly more rufescent.

Iris dark brown; bill black; feet gray.

Measurements.-Male: Total length (in flesh), 228.6-243 (average, $236.2 \mathrm{~mm} . ;^{1}$ extent of wing, 535.9-617.5 (596.6). ${ }^{1}$

Female: Total length (in flesh), 222.3-241.3 (232.5) ${ }^{2}$ extent of wing, 573-603.3 (593.7). ${ }^{3}$

Male $^{4}$ : Wing, 18s-209.5 (average, 199.7) mm.; tail, 104-116.5 (111.1) ; exposed culmen, 6.5-7.5 (7.0); tarsus, 13.9-15.8 (14.6); middle toe, 14-16.5 (15).

Female ${ }^{5}$ : Wing, 182-198 (189.5) ; tail, 102.5-117.5 (110); exposed culmen, 6.0-7.5 (6.6); tarsus, $12.5-14.8$ (14.1) ; middle toe, 13.2-16 $(14.7)$.

Type-locatity.-Fort Webster, southern New Mexico.

Geographical distribution.-Sonthwestern United States and extreme northwestern Mexico; south in migration through Mexico, probably to South America. Breeds in the Lower Austral, Upper Austral, Transition, and Canadian zones, north to Taos, central northern New Mexico; Montrose, southwestern Colorado; Keam's Canyon in Navajo County, San Francisco Mountain, and the Hualapai Mountains, in north central Arizona; west to Mellen, central western Arizona; Prescott, central Arizona; Picacho Peak, south central Arizona; and Nogales, central southern Arizona; south to Nogales, central northern Sonora; Babicora, central western Chihuahua; and Alamito (Presidio County), central western Texas; and east to Fort Stockton and Pecos City, central western Texas; Carlsbad and Roswell, southeastern New Mexico; with Santa Rosa and Glorieta, north central New Mexico. Migrates through Mexico, east to Tamaulipas, and west to Jalisco, and presumably through Central America. Winters probably in Sonth America.

Remarks.-The present race proves not to be relatively so light, particularly on the upper parts, as it has credit for being, and is darker than any of the other western United States forms excepting Chordeiles virginianus hesperis. The male is similar to the same sex of Chordeiles virginianus hesperis, but is lighter, more brownish

1 Ten specimens.

2 Six specimens.

${ }^{3}$ Five specimens.

4 Eleren specimens, from Arizona and New Merico.

5 Twelve specimens, from Arizona, New Mexico, and Chihuahua. 
above, with the light mottlings coarser, more numerous, and much more tawny; below lighter, the dark areas of the anterior parts more rufescent brown (less blackish) ; the light ground color of the posterior surface decidedly more buffy, the dark bar's narrower. From Chordeiles virginianus sennetti he may be distinguished by darker, much more rufescent upper parts, with coarser and more tawny light markings, and by the greater rufescence of the dark areas and the more buffy suffusion of the light areas on the ventral surface. He differs from Chordeiles virginianus virginianus in his much lighter, more brownish (less blackish) ground color above, the light mottlings being much more numerous, coarser, and more tawny; in the more rufescent hue of the dark areas of lower surface, and generally lighter tone below, the posterior parts more buffy, with narrower dark brown bars.

The female seems to be, on the upper surface, practically like the male, but is decidedly more buffy on the posterior lower parts. She may be distinguished from the female of Chordeiles virginianus hesperis by reason of her more rufescent (less grayish or blackish) brown ground color above, with much coarser, more tawny light markings.

The juvenal and first autumn plumages are much lighter on the upper parts than are those of any of the other races excepting Chordeiles virginianus sennetti and Chordeiles virginianus howelli. Compared with the latter they are much more rufescent above, and, because of this, somewhat darker.

As in other races, there is a considerable range of individual variation in both size and color. The ground color of the posterior ventral surface of the male is nearly always creamy or buffy white, but occasionally varies to almost pure white. The same parts in the female are buff or cream buff. The upper surface in both sexes is normally dark rufescent brown, even somewhat blackish, with tawny or tarny ochraceous mottlings. In some specimens, as, for instance, in No. 204516, U.S.N.M., male, from the Hachita Mountains, New Mexico, July 16, 1908, these light markings range to buff and even whitish. Sometimes the ground color of the upper parts is of a much lighter brown, so that it is much like that of Chordeiles virginianus howelli, as in No. 6013, U.S.N.M., male, from Nogales, Arizona, June, 1857; and No. 16587, Field Museum, male, from the Huachuca Mountains, June 7, 1901; but such specimens are distinguishable by the more buffy abdomen.

Breeding birds from southern Arizona and northern Chihuahua, Mexico, represent the extreme differentiation of the present race. Those from New Mexico are, as a whole, somewhat less ochraceous or tawny, but are just as dark. A specimen from Taos, in northern New Mexico, is intermediate between Chordeiles virginianus henryi 
and Chordeiles virginianus howelli, being lighter and less ochraceous abore, but, so far as we can determine from a single individual, it is nearer the former. Two specimens from Paisano, in central western Texas (Nos. 140404 and 140405, U.S.N.M.), taken, July 14, 1890, by Mr. William Lloyd, are less ochraceous above than even New Mexico birds, in this respect like Chordeiles virginianus howelli, but they are, nerertheless, dark like Chordeiles virginianus henryi; in size they are rather small, verging in this respect toward Chordeiles virginianus aserriensis; ${ }^{1}$ they seem, howerer, all things considered, to be properly referable to Chordeiles $v$. henryi, as they are much too dark and also too large for Chordeiles virginianus aserriensis. This identification is strengthened by two other specimens-one from Fort Stockton, western Texas (No.43532, M.C.Z.), taken, May 24, 1860 ; and the other from the crossing of the Pecos River, near the mouth of Delaware Creek, in southern New Mexico (No. 17607, M.C.Z.), taken, June 11, 1855 , both of which are seen to be much like typical Chordeiles virginianus henryi.

The amount of rariation in size among specimens of this subspecies from various parts of its range are illustrated in the subjoined table of average millimeter measurements:

\begin{tabular}{|c|c|c|c|c|c|}
\hline Localities. & Wing. & Tail. & $\begin{array}{l}\text { Exposed } \\
\text { culmen. }\end{array}$ & Tarsus. & $\begin{array}{c}\text { Midclile } \\
\text { toe. }\end{array}$ \\
\hline Six malos, from Arizona.. & $\begin{array}{l}m m . \\
198.8\end{array}$ & $\begin{array}{l}m m . \\
110.5\end{array}$ & $\begin{array}{r}m m . \\
7\end{array}$ & $\begin{array}{l}m m . \\
14.5\end{array}$ & $m m$. \\
\hline Five inales, from New Mexico... & 200.8 & 111.8 & 7.1 & 14.8 & 15.1 \\
\hline One male, from western Texas.... & 193 & 105 & 7 & 14. 1 & 14.2 \\
\hline Five females, from $\Lambda$ rizoma ......... & 187.2 & 107.8 & 6.5 & 13.9 & 14.6 \\
\hline Four females, from Chihuahua, Mexico ......... & 191 & 112.3 & 6.8 & 14.3 & 14.8 \\
\hline Three females, from Now Mexico.............. & 191.3 & 110.7 & 6.5 & 14.1 & 14.9 \\
\hline Three females, from western Texas and southeastern & & & & & \\
\hline New Mexico ..................... & 190 & 108.3 & 6.1 & 13.4 & 13.7 \\
\hline
\end{tabular}

A specimen of this race from Guadalajara, Jalisco, indicates that it migrates through Mexico on its way to and from its probable winter home in South America. There are records of Chordeiles virginianus "henryi" from Jerez, Zacatecas, Mexico;" Southern Pine Rigge, British Honduras; ${ }^{2}$ Bogota, Colombia; ${ }^{3}$ and South America down to Chupat, Patagonia ; ${ }^{2}$ but there is, in the absence of specimens, no means of determining to which one of the five western subspecies these records belong.

This subspecies breeds at about the same time of year as the more northern races; and there are eggs in the United States National

\footnotetext{
${ }^{1}$ See p. 71 .

2 Hartert, Cat. Birds Brit. Mus., vol. 16, 18ภ2, p. 613.

Idem, p. 612.
} 
Museum, taken by C. M. Barber, in the Sierra Madre of Chihuahua, at 8,000 feet altitude, on June 14, 1899; and from San Luis Spring in the San Luis Mountains in southwestern New Mexico, taken on July 3, 1892, by Dr. E. A. Mearns.

In the original description of Chordeiles virginianus henryi, ${ }^{1}$ $\mathrm{Mr}$. Cassin mentions specimens of this form that Dr. T. C. Henry obtained at Fort Webster, and that Lieut. Gunnison's exploring party collected in New Mexico. As we have already shown, ${ }^{2}$ Prof. S. F. Baird considered as the type the specimen which Kreutzfeldt, who was naturalist to Lieutenant Gunnison's party under Lieutenant Beckwith, collected in the San Luis Valley in southern Colorado, this being then a part of New Mexico. This supposed type is a juvenal female, whereas the bird actually described by Cassin is an adult male, the description of which agrees very satisfactorily in both color and size with the specimen now considered as the type in the Academy of Natural Sciences of Philadelphia. The bird now in question is marked on the present red type label, the original label having apparently been lost, as follows: " 24179 -Type of Chordeiles Henryi Cass. Bds. Col. \& Tex., p. 223 "; and on the reverse side, "Rio Grande Lat $32^{\circ}$ Dr T C Henry."

Witmer Stone, in his account of the type specimens of birds in the Academy of Natural Sciences of Philadelphia, ${ }^{3}$ gives the typelocality of Chordeiles virginianus henryi as "Rio Grande, Lat. 320," evidently copying the data from the label of the above specimen marked as type.

Cassin, in his original description of Chordeiles virginianus henryi, eviclently intended to base the name on the specimen obtained by Dr. T. C. Henry, for it is the one he fully describes and of which he gives measurements; furthermore, mentions the female (i. e., the specimen collected in southern Colorado by Mr. Krentzfeldt, of Lieutenant Gunnison's party) only incidentally and briefly; and speaks as follows of the origin of his material: " ${ }^{1}$ Specimens of this interesting species have been procured at Fort Webster, New Mexico, by Dr. Henry and by the unfortunate party under command of the late Lientenant Gunnison." Finally he named the new bird in honor of Dr. T. C. Henry. Thus it appears that Henry's specimen, now regarded as the type in the Academy of Natural Sciences of Philadelphia, is from Fort Webster, or it is from the Rio Grande at latitude $32^{\circ}$, or it is not the type. The first is undoubtedly the true statis of this case; for many of the labels used by Henry had printed on them the locality "Rio Grande Latitude $32^{\circ}$," and he doubtless tied one of these to the specimen, and neglected to change the locality. Furthermore, Cassin had ample opportunity to learn from Henry the true

${ }^{1}$ Illust. Birds Cal., Texas., Ore., Brit. and Russ. Amer., vol. 1, 1855, p. 239.

2 Pages 62-63.

3 Proc. Acad. Nat. Sci. Phila., 1899, p. 30. 
source of the specimen. Witmer Stone, in his above-mentioned account of the type, adds that another specimen with the same data is in the United States National Museum as No. 6005. It is, however", practically certain that this "No. 6005, U.S.N.M." is the very same as the real type now in the Academy of Natural Sciences of Philadelphia, for this specimen the Smithsonian Institution returned to Doctor Henry in 1859 , and the bird thence found its way into the Academy collection. In the bird catalogue of the United States National Museum (i. e., the Smithsonian Institution) it is entered as from "Rio Mimbres L. 32०"; and Professor Baird, who doubtless was aware of its true locality, recorded it ${ }^{1}$ as from the Rio Mimbres (i. e., Fort Webster). This is added evidence, if any be needed, that the type locality is Fort Webster, for Professor Baird was undoubtedly familiar with the correct localities of Doctor Henry's specimens, as other cases go to prove.

The type is a very dark specimen, blackish on the upper parts, with deep tawny markings, and is an extreme example of the Arizona race. It has been mounted and is somewhat discolored, though still well preserved.

Specimens examined.-Of this subspecies 62 specimens have been available, from the subjoined localities:

Arizona.-Fort Huachuca (June 2 and 3, 1892); Santa Cruz River, west of the Patagonia Mountains (June 7 and 21, 1893); Santa Rita Mountains (June 11 and 14, 1884); San Pedro River, Cochise County (June 10, 1902); Huachuca Mountains, 9,000 feet altitude (June 17 and 23, 1902; July 8 and 10, 1896; July 16, 1901; Aug. 17, 1902) ; foothills of Huachuca Mountains (June 7, 1901); Picacho Peak, Pinal County (May 9, 1885) ; Fort Whipple (Prescott) (Aug. 11, 1864); Winslow, 2 miles east of Little Colorado (July 10, 1887) ; Flagstaff (June 18, 1887) ; Salmon Lake (July 7, 1887).

Colorado.-Montrose (July 9, 1885).

New Mexico.-Carlsbad (Sept. 4, 1901); Hachita (July 16, 1908); Santa Fe (Aug. 23, 1882) ; A pache in Grant County (Aug. 18, 1886); Santa Rosa (June 3,1903) ; northwestern foothills of Capitan Mountains (June 30, 1903); Fort Webster; crossing of Pecos River, near the mouth of Delaware Creek (June 11, 1855, J. Pope) ; eastern side of San Luis Mountains, Mexican boundary line (June 25, 1892); Bear Ridge, Zuñi Mountains (June 14, 1909) ; Copperton (July 20, 1905); Taos, 7,400 feet altitude (July 15, 1904); Lang Ranch, Animas Valley (Aug. 11, 1908).

Texas.-Fort Clark (May 27, 1898); San Antonio (May 9, 1889); Paisano (July 14, 1890) ; Fort Stockton (May 24, 1860) ; Pecos City (May 24, 1887) ; 25 miles south of Alpine (July 2, 1901). 
Campeche.-La Tuxpana (Apr. 8, 1913; Sept. 7, 1910).

Chihuahua.-Chihuahua (Aug. 12, 1889); Whitewater, United States boundary line (June 17 and 20, 1892) ; Babicora (June 21, 1902 ) ; Pacheco (July 28, 1905; Aug. 6 and 12, 1905).

Jalisco.-Guadalajara.

Sonora-Nogales (June, 1857).

Tamaulipas.-Montelunga (Apr: 30, 1909) ; Victoria (Apr. 23, 1888).

Mcasurements of specimens of Chordeiles virginianus henryi.

\begin{tabular}{|c|c|c|c|c|c|c|c|c|c|}
\hline Museum and No. & Sex. & Locality. & Date. & Collector. & $\stackrel{\infty}{\equiv}$ & नี & 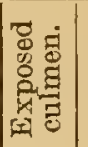 & 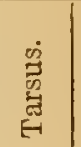 & $\stackrel{\circ}{\overrightarrow{0}}$ \\
\hline H. S. Swarth $2853^{1}$ & Male & San Pedro River & June 10,1902 & H.S. Swarth & $\mid \begin{array}{c}m m \\
209.5\end{array}$ & $\begin{array}{c}m m \\
112\end{array}$ & $\left|\begin{array}{c}m m \\
7\end{array}\right|$ & $\begin{array}{l}m m \\
15\end{array}$ & $\begin{array}{l}m m . \\
15.5\end{array}$ \\
\hline H. S. Swarth $22 S^{1}$. & ... do.... & $\begin{array}{c}\text { Huachuca Moun- } \\
\text { tains, Ariz. }\end{array}$ & June 10,1896 & do & 204 & 112 & 7.3 & 15 & 15.5 \\
\hline Morcom 30841 & . do & .....do........... & Aug. 17,1902 & do & 188 & 108 & 7.2 & 14.1 & 14.2 \\
\hline 1. & & ....do. & July 10 & & 197 & 112 & & 14.2 & 15.2 \\
\hline $\begin{array}{l}\text { Field Mus. N. H. } \\
16587.1\end{array}$ & ...do. & .....do. & June 7 & $\begin{array}{l}\text { G. F. Bren- } \\
\text { inger. }\end{array}$ & 189 & 104 & 6.5 & 13.9 & 14 \\
\hline U.S.N.M.129246 1 . . & ... do. & $\begin{array}{l}\text { Santa Cruz River, } \\
\text { west of Patago- } \\
\text { nia Mountains, } \\
\text { Ariz. }\end{array}$ & June 21,1893 & $\begin{array}{l}\text { F. X. Holz- } \\
\text { ner. }\end{array}$ & 205 & 115 & 7 & 15 & 15 \\
\hline Carnegie Mus. & & $\begin{array}{l}\text { Apache, Grant } \\
\text { Co., N. Mex. }\end{array}$ & Aug. 18,1886 & $\begin{array}{l}\text { A. W. An- } \\
\text { thony. }\end{array}$ & 206 & 110.5 & 7.5 & 15.8 & 16.5 \\
\hline U.S.N.M. $1866491 .$. & ... do. & $\begin{array}{l}\text { Capitan Moun- } \\
\text { tains, N. Mex. }\end{array}$ & June 30,1903 & J. H. Gaut. . & 191.5 & 107 & 6.5 & 14.2 & 14.7 \\
\hline $02^{1} \mathrm{i}$ & ...d & Hachita, N. Mex.. & July 16,1908 & C. Birdseye. & 201 & 112 & 7.1 & 14.8 & 15.5 \\
\hline U.S.N.M. 1861021 & ...d & Santa Kosa, N. & June 3 & $V . \mathrm{Ba}$ & 198 & 113 & 7 & 15 & 15 \\
\hline $\begin{array}{l}\text { A. N. S. Phila. } \\
24179.1\end{array}$ & [Male $\left.{ }^{2}\right]$. & $\begin{array}{l}\text { "Rio Grande,lat. } \\
32^{\circ "}=\text { FortW eb- } \\
\text { ster, N. Mex. }\end{array}$ & & T. C. Henry. & 207.5 & 116.5 & 7.2 & 14. & 14 \\
\hline U.S.N.M. 140404 & Mal & $\begin{array}{l}\text { Paisano, Brewster } \\
\text { Co., Tex. }\end{array}$ & July 14,1890 & W. Lloyd... & 193 & 105 & 7 & 14.1 & 14.2 \\
\hline Field Mus. N. H. & Female. & $\begin{array}{l}\text { Huachuca Moun- } \\
\text { tains, Ariz. }\end{array}$ & July 16, 1901 & G. F. Bren- & 183 & 102.5 & 6.9 & 14.5 & 15 \\
\hline H. S. Swarth & $\ldots d$ & …do.............. & $\begin{array}{l}\text { July 8,1896 } \\
\text { June 23.1902 }\end{array}$ & H. S. Swarth & $\left|\begin{array}{l}187.5 \\
192\end{array}\right|$ & 115 & 6.5 & 14 & 15.3 \\
\hline Am. Mus. N. H. & $\ldots d$ & 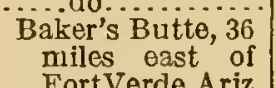 & July 10,1887 & E.A.Mearns & 182 & 106.5 & 6.1 & 14.5 & $\begin{array}{l}14 \\
14.5\end{array}$ \\
\hline$\underset{51996.1}{\operatorname{Am} . \text { Mus. N. H. }}$ & $\ldots d$ & ...do........ & $d$ & & 191.5 & 110 & 7 & 14 & 14.3 \\
\hline$\underset{81588.1}{\text { Am. Mus. N. H. }}$ & ...do & $\begin{array}{l}\text { Chihuahua, Chi- } \\
\text { huahua, Mex. }\end{array}$ & Aug. 12,1889 & [W. Lloyd].. & 197 & 116.5 & 7.3 & 14.5 & 14.5 \\
\hline $\begin{array}{l}\text { Field Mus. N. H. } \\
12670.1\end{array}$ & ... do & $\begin{array}{l}\text { Babicora, Chihua- } \\
\text { hua, Mex. }\end{array}$ & June 21,1902 & $\begin{array}{l}\text { G. F. Bren- } \\
\text { inger. }\end{array}$ & 184 & 107 & 7.5 & 14 & 14.5 \\
\hline $.127876^{1}$ & $\ldots$ do & $\begin{array}{l}\text { Mexican and } \\
\text { United States } \\
\text { boundary line } \\
\text { at Whitewater, } \\
\text { Chihuahua,Mex. }\end{array}$ & June 20,1892 & $\begin{array}{l}\text { E.A.Mearns } \\
\text { and F. X. } \\
\text { Holzner. }\end{array}$ & 192.5 & 117.5 & 6.5 & 14.8 & 15.3 \\
\hline U.S.N.M. & $\ldots . d c$ & $\begin{array}{l}\text { Whitewater, Chi- } \\
\text { huahua, Mex.. }\end{array}$ & June 17,1892 & E.A. Mearns & 190.5 & 108 & 6 & 13.9 & 14.8 \\
\hline U.S.N.M. 205627 1.. & $\ldots$ de & $\begin{array}{l}\text { Bear Ridge, Zuni } \\
\text { Mountains, N. } \\
\text { Mex. }\end{array}$ & June 14,1909 & $\begin{array}{l}\text { E. A. Gold- } \\
\text { man. }\end{array}$ & 187 & 111.5 & 6 & 13.5 & 13.2 \\
\hline $6 \begin{array}{ll}61 \\
66\end{array}$ & & Taos & & & 189 & 10 & 6.5 & 14.1 & 15.5 \\
\hline U.S. &..$d$ & Paisano, Brewster & July 14,1890 & iv. Lloyd. & 188 & 107 & 5.5 & 13 & 14 \\
\hline M.C.Z. 4 & $\ldots d$ & Fort Stockton, & May 24, 1860 & & 191.5 & 110.5 & 6.8 & 13.1 & 13.1 \\
\hline M.C.Z. 17607 & $\ldots \mathrm{d}$ & $\begin{array}{l}\text { Crossing of Pecos } \\
\text { River, near } \\
\text { mouth of Dela- } \\
\text { ware Creek, N. } \\
\text { Mex. }\end{array}$ & July 11,1855 & J. Pol & 190.5 & 107.5 & 6 & 14 & 14 \\
\hline
\end{tabular}

1 Used in measurement averages on p. 65 .

3 'Type. 
CHORDEILES VIRGINIANUS ASERRIENSIS Cherrie.

Chordeiles virginianus aserriensis Cherrie, Auk, vol. 13, April, 1896, p. 136 (Valley of Aserri River, San José, Costa Rica).

Chars. subsp.-Resembling Chordeiles virginianus sennetti, but decidedly smaller; general tone of upper parts lighter and more ochraceous, the light areas more buffy or ochraceous (less grayish or whitish) and somewhat more extensive; and the dark brown areas of anterior lower surface less grayish.

Measurements.-Male: Total length (in flesh), 223-240 (average 232) $\mathrm{mm} . ;^{1}$ extent of wing, $573-585$ (578.7). ${ }^{1}$

Male: ${ }^{2}$ Wing, 179-188 (average, 183:7) mm.; tail, 94.5-105 (101.1); exposed culmen, 6.0-7.9 (6.7) ; tarsus, 13.8-15.1 (14.5); middle toe, $13-14.8$ (13.9).

Female:" Wing, 179-185.5 (182.7) mm.; tail, 98.3-106 (102.6); exposed culmen, 6.3-7.5 (6.9) ; tarsus, 13.5-14.8 (14.2); middle toe, 14-15.5 (14.4). Rica.

Type-locality.-Valley of the Aserri River, near San José, Costa

Geographical distribution.-Central southern Texas, and northern Tamaulipas, Mexico; south in migration to Costa Rica and probably South America. Breeds in the Lower Austral Zone, north to San Antonio and Rock Springs, south central Texas; west to Samuels, Texas; south to Matamoros, northeastern Tamaulipas, Mexico; and east to Brownsville, Corpus Christi, Wharton County, and Richmond, central southern Texas. Migiates south through eastern Mexico and Costa Rica. Winters probably in South America.

Remarks.-This heretofore unrecognized race seems to be in color most nearly like Chordeiles virginianus sennetti, though in this respect also near Chordeiles virginianus howelli and probably in reality most closely resembling this form, which it adjoins geographically. From the latter it may be distinguished in the male by smaller size, rather lighter, somewhat less brownish (more grayish) upper parts, with less ochraceous (more whitish or grayish) markings, and slightly less buffy posterior lower parts. It differs more strongly from Chordeiles virginianus henryi in its smaller size; much lighter, more grayish (less brownish) upper surface, with finer, much more grayish and whitish (less ochraceous and tawny) light markings; nearly or quite white, instead of buffy, posterior lower surface; and less rufescent dark areas of the anterior under parts.

The female of this subspecies is much more deeply buffy on the posterior lower surface than is the male, and also averages slightly 
paler, more brownish above, with markings more tawny or ochraceous. She may be differentiated from the female of Chordeiles virginianus howelli by her lighter, less brownish (more grayish) upper surface, with less tawny and ochraceous in the light markings; and by the less deeply buffy lower parts.

No juvenal or first autumn specimen of Chordeiles virginianus aserriensis has been available, but in this plumage this race is doubtless similar to that of Chordeiles virginianus howelli, though more grayish; that is, intermediate in color between the latter form and Chordeiles virginianus sennetti.

Individual variation has about the same range as in other races, though greater than in some. In the male the posterior lower parts are usually almost pure white, occasionally washed with buff; the breast and jugulum dark brown, varying to a much lighter shade, which is still further lightened by being much obscured by large buff and cream buff spots. The upper surface of the male is in color normally somewhere between Chordeiles virginianus sennetti and Chordeiles virginianus howelli, but rather lighter than either. From this it varies to (1) a much more brownish shade, with buffy ochraceous markings, so that it is practically like Chordeiles virginianus hourelli, as in No. 81582, American Museum of Natural History, Corpus Christi, Texas, April 24, 1889; to (2) a still lighter brown, which is more hearily light-mottled, as in No. 152229, U.S.N.M., San Antonio, Texas, May 9, 1891; to (3) a very grayish and blackish condition, with the light mottlings somewhat reduced, so that it becomes almost like Chordeiles virginianus sennetti, as in No. 27307, Acad. Nat. Sci. Phila., Corpus Christi, Texas, May 23, 1891; and to (4) a condition like the last, but with the light mottlings much reduced, so that the general tone is much more blackish-almost identical with typical Chordeiles virginianus hesperis, as in No. 203649, U.S.N.M., Runge, Texas, September 21, 1906. These variations are, of course, exceptional; and Chordeiles virginianus aserriensis is so much smaller than any of the races that it closely resembles in color that there should usually be no difficulty in identifying specimens. Some such individuals as (3) have been identified as Chordeiles virginianus "sennetti," and the so-called Texas "type" of Chordeiles virginianus sennetti has been found to be one of these. In the female the ground color of the posterior lower surface ranges from buffy white to deep buff, and averages about cream buff. The upper parts vary about as in the male: To (1) a light brown with ochraceous mottling, rery much like the same sex of Chordeiles virginianus howelli, as in No. 19853, Carnegie Museum, Cameron County, Texas, May 16, 1902; to (2) a similar light brown, more heavily mottled, but with less ochraceous, as in No. 197786, U.S.N.M., Runge, Texas, August 25, 1905 ; and to (3) a very dark, blackish brown, with much reduced light mark- 
ing, so that it closely resembles the female of Chordeites virginianus hesperis, as in No. 81569, Amer. Mus. Nat. Hist., Corpus Christi, Texas, May 15, 1882.

The limited breeding area of this race permits little opportunity for geographical variation within its boundaries, and there is none worth mentioning. This bird breeds in Texas from April to July, and there are eggs in the United States National Miseum collected from April 24 to June 28.

An adult male of this race in the Sennett collection (No. 81591, Amer. Mus. Nat. Hist.), from Wharton County, Texas, taken May 27,1887 , was marked by Dr. Elliott Coues as one of the types of his Chordeiles popetue [= virginianus] sennetti, ${ }^{1}$ and upon this basis the range of the latter was extended to Texas. This specimen, as we have already shown, ${ }^{2}$ can not be considered the type of Chordeiles virginianus sennetti, but must be referred to the present form.

Regarding the name we are here using for this race the following remarks are necessary: G. K. Cherrie some 18 year's ago described ${ }^{3}$ a nighthawk from a few specimens from Central America. His type was a specimen taken on the Aserri River, near San José, Costa Rica, and he therefore called the supposed new race Chordeiles virginianus aserriensis. I have made every effort to trace this type specimen, but without any success; and $\mathrm{Mr}$. Cherrie himself assures me that he has no idea where it finally went. The application of this name inust therefore be settled chiefly by the original description. There is no doubt that $\mathrm{Mr}$. Cherrie had in hand a male nighthawk of the virginianus style in fully grown juvenal or first autumn plumage, not adult, as he supposed. Allowing for this immaturity, the characters that Mr. Cherrie gives are just those distinguishing the small, pale race which summers in southern Texas. A little additional light is thrown on the subject by a juvenal male nighthawk, No. 128373, U.S.N.M. (still in the National Museum), collected by Dr. C. W. Richmond on the Escondido River, 50 miles from Bluefields, Nicaragua, October 28, 1892. This specimen Mr. Cherrie refers to his new race with the remark that it is much darker on the upper surface than his type, as it should be, for it turns out to be really an example of Chordeiles virginianus hesperis! It is, of course, often difficult, owing to the great range of individual variation in all the races of this species, to identify a specimen with absolute certainty from a description alone; but in this case, in view of the rather full description which agrees in all respects with the characters of the present form, it seems best to use for this race the title

\footnotetext{
1 Auk, vol. 5, January, 1888, p. 37.

2 Pages 55-56.

${ }^{3}$ Auk, vol. 13, April, 1896, p. 136.
}

$13732^{\circ}-$ Bull. $86-14-6$ 
Chordeiles virginianus aserriensis until this name can be proved ineligible from an examination of the type.

Specimens examined.-Fifty-three specimens of this race have been handled, from the following localities:

Texas.--Fort Brown (June 25 and 28, 18т $)$ ) Brownsville (Apr. 15, 1892; Apr. 25, 1889; Aug. 11, 1891) ; Cameron County (May 6, 8, 10, 12, and 16, 1902; May 7, 1903) ; Fort Clark (Apr. 29, 1893; May 17, 1893; May 25, 1898) ; Rock Springs (July 11, 1902) ; Corpus Christi (Apr. 14, 1900; Apr. 24, 1889; Apr. 26, 1882; May, 1892; May 15, 1882; May 23, 27, 30, and 31, 1891; June, 1886; June 13, 20, and 23, 1887; July 5, 1887; Nov. 6, 1909); Bee County (Apr. 18 and 19, 1887) ; Runge (Aug. 25, 1905; Sept. 21, 1906); San Antonio (May 9, 1891); Wharton County (May 27, 1887) ; Refugio County (June 6, 1887).

Campeche.-La Tuxpana (May 8, 1912; Sept. 28, 1912 ; Oct. 5, 1912).

Tamaulipas.-Matamoros (Aug. 15 and 23, 1908).

Heasurements of specimens of Chordeiles virginianus aserriensis.

\begin{tabular}{|c|c|c|c|c|c|c|c|c|c|}
\hline Museum and No. & Sex. & Locality. & Date. & Collector. & 总 & न्दु & 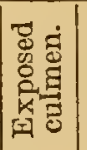 & 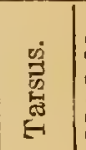 & 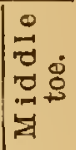 \\
\hline H. & Male ${ }^{2}$ & WhartonCo.,Tex. & May 27,1887 & & $\begin{array}{l}m m . \\
184.5\end{array}$ & $\frac{m m}{102}$ & $\begin{array}{r}m m . \\
7.2\end{array}$ & $m_{15}^{m}$. & $\min _{14}$ \\
\hline $\begin{array}{l}81591.1 \\
\text { Am. Míus. N. H. }\end{array}$ & $\ldots d$ & $\begin{array}{c}\text { Corpus Christi, } \\
\text { Tex. }\end{array}$ & June 3,1887 & & 187 & 101 & 7.9 & 14 & 14 \\
\hline 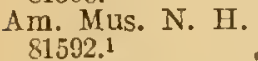 & ...do.. & & Apr. 26,1882 & & 182 & 101 & 6.1 & 13.8 & 14.3 \\
\hline 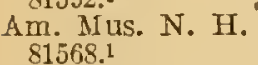 & ...do.. & .....do. & July $\quad 5,1887$ & & 185.5 & 101 & 6.5 & 14. & 13.5 \\
\hline m. Mus. N. H. & ...do.. & ....do.. & May 6,1892 & C. A. Smith. & 188 & 105 & & 15.1 & 13 \\
\hline $\begin{array}{l}\text { U.S.N.M. } 1659621 . . \\
\text { A.S. IN. S. Phila. }\end{array}$ & $\begin{array}{l}\text {..do... } \\
\ldots \text {.. do.. }\end{array}$ & $\begin{array}{l}\text {.....do.. } \\
\text {.....do.. }\end{array}$ & $\begin{array}{l}\text { Apr. } 14,1900 \\
\text { May } 23,1891\end{array}$ & $\begin{array}{l}\text { V. Bailey.... } \\
\text { s.N.Rhoads. }\end{array}$ & $\begin{array}{l}182 \\
182\end{array}$ & \begin{tabular}{|l|}
104 \\
100.3
\end{tabular} & $\begin{array}{l}6 \\
6.9\end{array}$ & $\begin{array}{l}14.8 \\
14.3\end{array}$ & 14.8 \\
\hline $\mathrm{Am}_{\delta 1590 .}$ Mus. N. H. & ...do. & Brownsville, Tex. & Apr. 25,1900 & & 181.5 & 94.5 & 6.5 & 14.5 & 14.5 \\
\hline $\begin{array}{c}\delta 1590.1 \\
\text { Am. Mus. N. H. }\end{array}$ & $\ldots \mathrm{do}$ & Bee Co., Tex. & Apr. 18,1887 & & 179 & 99 & 6.5 & 14 & 13 \\
\hline Am. Mus. N. H. & ...do. & Refugio Co., Tex.. & June 6,1887 & & 185 & 103.5 & 7 & 14.7 & 14 \\
\hline Am. Mus. N. H. & Female. & $\begin{array}{l}\text { Corpus Christi, } \\
\text { Tex. }\end{array}$ & Apr. 24,1889 & J. A. Singley & 183 & 99.5 & 7.5 & 14.5 & 14 \\
\hline$\underset{81585^{1}}{\text { Am. Mus. N. H. }}$ & ...do.. & & .....do.. & do & 185 & 100.5 & 6.5 & 14.6 & 14.6 \\
\hline$\underset{81595.1}{\text { Am. Mus. N. H. }}$ & ...do.. & ....do & June 23,1887 & & 185 & 104.8 & 6.8 & 14 & 14.3 \\
\hline is. N. H. & ...do.. & ....do. & June 20,1887 & & 184 & & 7 & 14. & \\
\hline Am. Mus. N. H. & ...do.. & ......do & June 23,1887 & & 185 & 103 & 7.1 & 14 & 14 \\
\hline A. N. S. Phila. & ...do.. & .....do. & May 31,1891 & S.N.Rhoads. & 179 & 106 & 6.9 & 14 & 14 \\
\hline A. S. N. Phila. & ...do.. & ....do. & May 30,1891 & .....do.. & 185 & 102 & 6.5 & 14 & 14 \\
\hline $\begin{array}{l}\text { U.S.N.M. } 1977861 \\
\text { U.S.N.M. } 730191 \ldots\end{array}$ & $\begin{array}{l}\ldots \text { do } \\
\ldots \text { do. }\end{array}$ & $\begin{array}{l}\text { Runge, Tex ...... } \\
\text { Fort Brown, Tex. }\end{array}$ & $\begin{array}{l}\text { Aug. } 25,1905 \\
\text { June } 25,1877\end{array}$ & $\begin{array}{l}\text { A.H.Howell } \\
\text { J.C. Merrill. }\end{array}$ & 182 & $\begin{array}{l}106 \\
103\end{array}$ & $\begin{array}{l}7.5 \\
6.5\end{array}$ & $\begin{array}{l}13.5 \\
14.5\end{array}$ & $\begin{array}{l}14.3 \\
15.5\end{array}$ \\
\hline $\begin{array}{c}\text { Carnegie lius. } \\
19853.1\end{array}$ & & Cameron Co.,Tex. & May 16,1902 & & 179 & 98.3 & 6.3 & 14 & 14 \\
\hline
\end{tabular}

1 Used in measurement averages on p. 71.

2 Marked by Dr. E. Coues as one of the types of Chordeiles virginianus sennetti. 
CHIORDEILES VIRGINIANUS CHAPMANI CouES.

[Chordiles popetue] Chapmani Coues, Auk, vol. 5, January, 18s8, p. 37 (ex Sennett MS.) (Gainesville, Florida).

Chars. subsp.-Like Chordeiles virginianus virginianus, but decidedly smaller; upper parts averaging a little more mottled and spotted with whitish and buffy, particularly on back, wings, and scapulars, and the ground color averaging slightly less deeply blackish (more grayish or brownish); posterior lower parts usually more purely white.

Iris brown or hazel brown; bill black or dull blackish; feet dull grayish brown, dull or dark horn color.

Measurements.-Male: Total length (in flesh), 223-232 (average, $227.5) \mathrm{mm}$. ; $^{1}$ extent of wing, 451-580 (515.5). ${ }^{1}$

Female : Total length (in flesh), 209.6-235 $(223.5)^{2}$; extent of wing, $533.4-575(561.6) .^{3}$

Male ${ }^{4}$ : Wing, 178-192 (average, 184.1) mm.; tail, 99-110.5 (105); exposed culmen, 4.8-7.0 (6.3) ; tarsus, 12.5-15.5 (13.9); middle toe, $13-15.8(14.2)$.

Female: ${ }^{5}$ Wing, 172.5-184.5 (179.4). mm.; tail, 99-108.5 (103.2); exposed culmen, 5.0-7.5 (6.3) ; tarsus, 13.2-15 (14); middle toe, 13.8-15.8 (14.4).

Type-Locatity.-Gainesville, northern Florida.

Geographical distribution.-Southeastern United States, south in winter to southern South America. Breeds in the Lower Austral and Upper Tropical zones, north to Fort Macon, central eastern North Carolina; Raleigh, central North Carolina; Chester County, north central South Carolina; Augusta, central eastern Georgia; Coosada and Greensboro, central Alabama; Mount Carmel, southeastern Illinois; Irickman, southwestern Kentucky; Stuttgart and Delight, south central Arkansas; and New Boston in Bowie County, northeastern Texas; west to Rice's Prairie in Bowie County, and Galveston Island, eastern Texas; south to Galveston Island and Sabine, southeastern Texas; Calcasieu Pass, Avery Island, and Houma, southern Louisiana; Bay Saint Louis and Biloxi, southeastern Mississippi; Petit Bois Island, southwestern Alabama; Pensacola and the lower part of the Suwanee River, northwestern Florida; and Tarpon Springs, Puntarasa, and Key West, western Florida; east to Miami, Canaveral, and Fernandina, eastern Florida; St. Marys, mouth of Altamaha River, and Savannah, southeastern Georgia; Mount Pleasant, southeastern South Carolina; and Fort Macon, central eastern North Carolina. Migrates south through the Greater Antilles (probably), Yucatan, Nicaragua, and Costa Rica, to South

Ten specimens from Florida. 
America. Winters in southern South America, south to Concepcion del Uruguay, and Ysca Yacu in the Province of Santiago, northern Argentina; and north to Chapada in Matto Grosso, central western Brazil.

Remarls.-Although the Florida nighthawk is commonly supposed to be in color exactly like Chordeiles virginianus virginianus, it has certain color characteristics which are at least average, as the above diagnosis indicates. The male of Chordeiles virginianus chapmani differs from that of Chordeiles virginianus hesperis in his smaller size, darker, rather more blackish (less brownish), upper parts, which have fewer light mottlings. From Chordeiles virginianus aserriensis he is distinguishable by his much darker upper surface, the dark areas being more blackish, less grayish, brown, with much less numerous light mottlings; and darker lower parts, the dark areas anteriorly being more blackish, and the posterior portion more heavily barred.

The female, except, of course, for differences common to all the subspecies, is almost identical with the male in color and markings above, though averaging in general tone slightly more brownish; but the posterior lower parts are more buffy. She is similar to the female of Chordeiles virginianus virginianus, but averages a little less brownish (more blackish) on the upper surface, and somewhat less buffy or ochraceous on the posterior lower parts.

The first autumn plumage is practically identical with that of first autumn Chordeiles virginianus virginianus. Above this is much like adult $C$ hordeiles virginianus sennetti, and, indeed, occasional specimens are scarcely distinguishable on the upper surface, though usually the dark areas are more deeply blackish and the light markings finer. It is also much like the adult of Chordeiles virginianus hesperis on the upper surface, but lighter, the dark areas being less deeply black (more grayish or brownish), more extensively and finely mottled with whitish, particularly on back, scapulars, and tertials.

Individual and seasonal variations in this race are practically the same as in Chordeiles virginianus virginianus.

There seems to be little geographical variation throughout the rather extensive breeding range of this subspecies, for specimens from southeastern South Carolina, Florida, southern Alabama, southern Louisiana, and southeastern Texas are practically identical in both size and color. A single example (No. 84251, U.S.N.M.) from Mount Carmel, Illinois, taken, June 7, 1874, is, in measurements, nearer the present race, though in color like Chordeiles virginianus virginianus, but on the whole seems best referred to the former. A female from Stuttgart, Arkansas, taken, May 13, 1910, is apparently typical Chordeiles virginianus chapmani. A single male (No. 57904, U.S.N.M.) from Macou, North Carolina, collected, June 10, 1869, is surely of 
the present race, and represents the breeding form of this locality, though a female from the same locality and taken on the same date appears to be a belated migrant Chordeiles virginianus virginianus. Birds from Raleigh, North Carolina, of dates from August 5 to August 10, are decidedly nearer the Florida race than to Chordeiles virginianus virginianus, as the accompanying measurements show. A table of comparative average measurements of specimens from various parts of the range of Chordeiles virginianus chapmani, from which may be seen any local differences in size, is here appended:

\begin{tabular}{|c|c|c|c|c|c|}
\hline Localities. & Wing. & Tail. & $\begin{array}{l}\text { Exposed } \\
\text { culmen. }\end{array}$ & Tarsus. & $\begin{array}{c}\text { Middle } \\
\text { toe. }\end{array}$ \\
\hline Fourteen males, from Florida.... & $\begin{array}{c}m m . \\
184.1\end{array}$ & $\begin{array}{r}m m . \\
105\end{array}$ & $\begin{array}{r}m m . \\
6.3\end{array}$ & $\begin{array}{c}m m . \\
13.9\end{array}$ & $\begin{array}{l}m m . \\
14.2\end{array}$ \\
\hline Three males, from Alabama... & 182.8 & 104.2 & 6.8 & 14.3 & 15 \\
\hline Two males, from Texas..................... & 183.8 & 102.3 & 6.9 & 15 & 15.3 \\
\hline One male, from Louisiana............ & 189 & 103 & 6.7 & 15 & 15 \\
\hline One male, from southern Illinois........ & 186 & 115 & 6.5 & 14.5 & 14.5 \\
\hline Two males, from North Carolina.................. & 190 & 106 & 6.6 & 14 & 14.3 \\
\hline Ten females, from Florida.. & 179.4 & 103.2 & 6.3 & 14 & 14.4 \\
\hline Three females, from southern Alabama.... & 175.3 & 101.3 & 6.5 & 15.2 & 15.5 \\
\hline One female, from Texas........... & 178.5 & 102 & 7 & 15 & 15 \\
\hline One female, from Louisiana...... & 186 & 104.5 & 7.1 & 14.9 & 15.8 \\
\hline 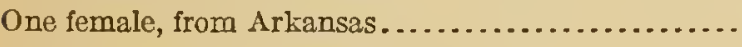 & 178.5 & 102.5 & 6.8 & 15 & 16 \\
\hline Two females, from North Carolina................ & 185.8 & 106 & 6.6 & 14 & 15.6 \\
\hline
\end{tabular}

The present race winters in Argentina, and its route of migration lies, so far as the present material indicates, across the Gulf of Mexico, through southeastern Mexico, Central America, and South America. Possibly some individuals follow the coast of eastern Mexico, as there is a specimen from Brownsville, in the extreme southern corner of Texas, taken on March 15. There is, however, not a record from any of the islands of the West Indies, but we have examined a specimen taken at sea off the coast of Colombia. It lingers in Central America, at least sometimes, until about the 1st. of June, for M. A. Carriker obtained it at Miravalles, Costa Rica, on May 27, 1906. ${ }^{1}$ It rears apparently but one brood, though we have records of eggs from April 24 to June 17.

Specimens examined.-The specimens of the present form examined number 107, from the localities in the list below:

Alabama.-Dauphine Island (May 18, 1911); Bayou La Batre (Aug. 2, 1911; July 25, 1911) ; Mobile Bay (Apr. 19, 1892) ; Abbeville (June 9, 1911) ; Petit Bois Island (July 28, 1911; Aug. 30. 1911); 5 miles west of Greensboro (June 26, 1890); Wilsonville (June).

\footnotetext{
1 The label of this specimen reads June 27, 1906, which 1s evidently a lapsus for May 27, since Mr. Carriker records specimens of Chordeiles virginianus from this locality on May 24 and 25, 1006 (Ann. Carnegie Mus., $\nabla 01.6,1910$, p. 501), and this subspecies does not breed south of the United States.
} 
Arkansas.--Stuttgart (May 13, 1910).

Florida.-Wolf Island Bluff Landing, lower Kissimmee River (Apr. 10, 1907) ; Jacksonville (Apr. 12, 1869; Apr. 20, 22, and 23, 1877) ; Dry Tortugas (Apr. 17, 1890; Apr. 20, 1902) ; Alligator Bluft; Kissimmee River (Apr. 23 and 28, 1901); Hillsboro (May 17; 1900); Tarpon Springs (June 6, 15, 21, and 28, 1893; July 5, 6, 12, 15, and 28, 1893); Amelia Island (Apr. 20, 1901); Allen's Creek, near Tampa (Apr. 19, 1883); Whitfield (Apr. 24 and 25, 1903); near Tantie, southern St. Lucie County (Apr. 20 and 24, 1904); Fleming's Island, Lake Tahopekaliga, near Kissimmee (May 9 and 10, 1901); San Mateo (May 24, 1892); Gainesville (May 19 and 20, 1887); West Jupiter (June 2, 1896; Apr. 25, 1896); Clearwater (Sept. 18, 1896) ; Moses Creek (May 16,1894) ; Pellicier's Creek (May 20, 1894); Tampa ; Merritt's (May 9, 1886).

Illinois.-Mount Carmel (June 7, 1874).

Louisiana.-Avery (June 7; 1895); Avery's Island (May 7, 1896).

North Carolina.-Raleigh (Aug. 5, 1896; Aug. 8, 1894; Aug. 10, 1893); Fort Macon (June 10, 1869).

South Carolina.-Lady's Island (May 6, 1869) ; Anderson.

Texas.-Sour Lake (July 15, 1902); Rockport (Aug. 18 and 23, 1893); Sabine (Sept. 2, 1902); China (Aug. 11, 1902); Victoria (Sept. 10, 1906) ; Corpus Christi (Oct. 21, 1909) ; Brownsrille (Mar. 15, 1892) ; Rice's Prairie, near New Boston, Bowie County (June $18,1888)$.

Campeche.-La Tuxpana (Sept. 28, 1912).

Yucatan.-Xbac (April, 1910).

Argentina.-Concepcion del Uruguay, Province of Entre Rios (Dec. 12, 1880; Jan. 28, 1880) ; Y'sca Yacu, Province of Santiago del Estero (Feb. 3, 1906).

Brazil.-Chapada, Province of Matto Grosso (Sept. 26, 1885).

Colombia.-Forty miles offshore and 200 miles from Panama (October, 1864).

Costa Rica.-Rio Sicsola, Talamanca (Sept. 24 and 26, 1904); Miravalles (May ["June" on label] 27, 1906).

Nicaragua.-[No further locality specified.]

Measurements of specimens of Chordeiles virginianus chapmani.

\begin{tabular}{|c|c|c|c|c|c|c|c|c|c|}
\hline Museum and No. & Sex. & Locality. & Date. & Collector. & $\sum^{\infty}$ & Еีं & 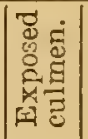 & 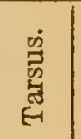 & 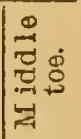 \\
\hline Fleld Mus. N. H. & Male $2 . .$. & Gainesville, Fla... & May 19,1887 & $\begin{array}{l}\text { F. M. Chap- } \\
\text { man. }\end{array}$ & $\underset{179}{m m}$ & $\begin{array}{c}m m . \\
103.5\end{array} \mid$ & $\begin{array}{r}m m \\
5.5\end{array}$ & $\begin{array}{l}m m . \\
14\end{array}$ & $\begin{array}{l}m m \\
14\end{array}$ \\
\hline Am. Mus. N. H. & ...do..... & $\begin{array}{l}\text { Near Tantie, St. } \\
\text { Lucie Co., Fla. }\end{array}$ & Apr. 20,1904 & & 189 & 107 & 5.2 & 14.2 & 15.2 \\
\hline$\underset{76530.1}{\operatorname{Am} . \text { Mus. N. H. }}$ & [Male]... & Dry Tortugas, Fla. & Apr. 20,1902 & $\begin{array}{l}\text { J. T ho m p- } \\
\text { son. }\end{array}$ & 188 & 104.5 & 6.5 & 15.5 & 15.5 \\
\hline
\end{tabular}

1 Used in measurement averages on p. 75.

2 'Гуре. 
Mcasurcments of spccimens of Chordciles virginianus chapmani-Continued.

\begin{tabular}{|c|c|c|c|c|c|c|c|c|c|}
\hline M & x. & $\cdot$ & . & r. & $\stackrel{E}{E}$ & है & 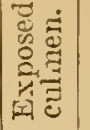 & 芑 & 总总 \\
\hline 8881 & Male. & & 1901 & E. A. Mit & $\begin{array}{ll}m m . \\
183\end{array}$ & $\begin{array}{l}m m . \\
106.5\end{array}$ & $\begin{array}{r}m m . \\
4.8\end{array}$ & $\begin{array}{c}m m \cdot \\
14\end{array}$ & $\begin{array}{c}m m . \\
11.2\end{array}$ \\
\hline 0. & [Míalc & $\begin{array}{r}\text { er } \\
\text { Alle }\end{array}$ & Apr. 19,1883 & & 181. & 105 & 0.5 & 12.5 & 14 \\
\hline Cus. & Male & Whitfield, Fla. & Apr. 25,1903 & w $_{\text {Todd. }}$ E. & 178 & 99 & 6.5 & 13 & 14 \\
\hline i e Mus. & .. de & $\underset{\substack{\text { Amelia } \\
\text { Fla. }}}{\text { Island, }}$ & Apr. 2 & W W w & 185 & 103. & 6.1 & 13.5 & 13 \\
\hline i e Mus. & ... do. & $\begin{array}{l}\text { Wolf Island Bluft } \\
\text { Landing, Lower } \\
\text { Kiss im me e } \\
\text { River, Fla. } \\
\text { Hillsboro Co., Fla. }\end{array}$ & May 17,1900 & & 190.5 & 104 & 6.7 & 15 & 15. \\
\hline $\begin{array}{l}\text { A. } \\
\text { A }{ }_{43932.1}^{N} \text { S. Phila. }\end{array}$ & $\ldots \mathrm{do}$ & $\begin{array}{l}\text { Tarpon Springs, } \\
\text { Fla. }\end{array}$ & June 6,1893 & & 182 & 101 & 6 & 14 & 15.3 \\
\hline A. N. S. Phila. & .. do & & June 15,1893 & & 179 & 107 & 6.8 & 13.5 & 14 \\
\hline $\begin{array}{c}\text { A. N. S. Phila. } \\
43993.1\end{array}$ & .do. & ....do... & July 6,1893 & & 186 & 103.5 & 7 & 13.8 & 4 \\
\hline $\mathrm{A}_{31905.1}$ N. Phila. &. do & $\ldots c$ & & & 185 & 107.5 & 6.8 & 13.8 & 14. \\
\hline S. Phila. & . do. & $\ldots$. & July 15,1893 & do & 192 & 110.5 & 6.8 & 14 & 14. \\
\hline 0493. & .. do & Petit Boís Island, & July 28,1911 & J. S. Gutsell. & 178 & 102 & 6.5 & 14. & 15. \\
\hline 491. & ..do & La Batre, & July 25,1911 & ..do. & 179 & 101 & 7 & 14. & 14. \\
\hline & de & $\begin{array}{l}\text { Abbe } \\
\text { Sabin }\end{array}$ & $\begin{array}{l}\text { June } 9,1 \\
\text { Sept. } 2,1\end{array}$ & A.H. & 191. & 109.5 & $\begin{array}{l}7 \\
7.3\end{array}$ & $\begin{array}{l}13.5 \\
15.5\end{array} \mid$ & $14 . \varsigma$ \\
\hline U.S. & .. do & Rockport, Tex. & Aug. 18,1893 & Att- & 187. & 101 & 6.5 & 14.5 & 14. \\
\hline 3097. & do & sland, & May 7,1896 & cIl- & 159 & 103 & 6.7 & 15 & 15 \\
\hline & & & $\begin{array}{l}\text { June } 7 \\
\text { June } 10\end{array}$ & $\begin{array}{l}\text { S. } \\
\text { E. }\end{array}$ & 186 & $\begin{array}{l}115 \\
102\end{array}$ & $\begin{array}{l}6.5 \\
6.2\end{array}$ & $\begin{array}{l}14.5 \\
14\end{array}$ & 14.5 \\
\hline S. Phila. & .. & 7 & Aug & H. ${ }_{\text {S. }}^{H}$. & 130 & 106 & 7 & & \\
\hline S. Phila. & ...do & ... do & Aug. 8, 1894 & & 190 & 106 & 6.2 & 14 & 4 \\
\hline Mus. N. K. & Fem & West Jupiter, Fla. & June 2,1896 & & 176 & 100 & 6.8 & 14 & 15 \\
\hline us. N. H. & .. do. & $\ldots . d$ & .... do. & & 177 & $|104.5|$ & 0 & 14 & 14. \\
\hline $\begin{array}{l}\text { A. N. S. Phila. } \\
43998.1\end{array}$ & ...do. & $\begin{array}{l}\text { Tarpon Springs, } \\
\text { Fla. }\end{array}$ & July 12,1893 & W. & 172. & 104.5 & 5 & 13.5 & 13. \\
\hline A. N. S. Phila. & .. do & & July 15,1893 & & 179 & 102 & 7.5 & 14 & 14 \\
\hline U.S.I & ...do & $\begin{array}{r}\text { Flemi } \\
\text { Lak } \\
\text { kali } \\
\text { sim } \\
\ldots . \text { d }\end{array}$ & May 10,1901 & E. A. & 182 & 101.5 & 6.2 & 15 & 5.8 \\
\hline & & , & & iv. & 182 & 104.5 & 6.2 & 13.2 & 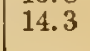 \\
\hline U.S.? & ..do. & & May 18,1911 & A. H. & 170 & $|99.5|$ & 6.2 & 15.7 & 15. \\
\hline & & & Aug. 2,1911 & J.S & 173 & 99.5 & 6.5 & 15 & 16 \\
\hline U.S. & & & & & $\begin{array}{l}178.5 \\
186\end{array}$ & 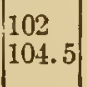 & 7.1 & $\begin{array}{l}15 \\
14.9\end{array}$ & 5 \\
\hline M.C. & & $\begin{array}{r}\text { Stu } \\
\mathrm{Co} \\
\mathrm{I}\end{array}$ & $\begin{array}{l}\text { Mar } \\
\text { Dec }\end{array}$ & ${ }_{\text {ro }}^{A . H}$ & $\begin{array}{l}178 . \\
176\end{array}$ & $\begin{array}{c}102.5 \\
97\end{array} \mid$ & $\begin{array}{l}6.8 \\
6.7\end{array}$ & $\begin{array}{l}15 \\
13.5\end{array}$ & $\begin{array}{l}16 \\
15\end{array}$ \\
\hline A. N. S. Phila. & $\ldots d$ & Raleigh, N. C..... & Aug. 10,1893 & $\mathrm{H}_{\mathrm{S}} \mathrm{I}$. & 183 & 107 & 7.1 & 14 & 15.1 \\
\hline $\begin{array}{l}\text { N. S. Phila. } \\
\text { 44403. }\end{array}$ & & do & do & & 188 & 105 & 6 & 14 & 16 \\
\hline
\end{tabular}

1 Used in measurement averages on p. 75 . 
CHORDEILES VIRGINIANUS VICINUS Riley.

Chordeiles virginianus vicinus RILEY, Auk, vol. 20, October, 1903, p. 432 (Long Island, Bahama Islands).

Chars. subsp.-Resembling Chordeiles virginianus chapmani, but considerably smaller; the upper surface lighter, owing to more numerous light markings; and the posterior lower parts more tinged with buff, and thus darlier.

Measurements.-Male: ${ }^{1}$ Wing, $162.5-183$ (average, 170.2$) \mathrm{mm}$; tail, 92-103 (96.8); exposed culmen, 6.1-7.8 (6. $)$; tarsus, 13-14.8 (13.4) ; middle toe, $13-15$ (13.9).

Female: ${ }^{1}$ Wing, 160.5-184.5 (173.2) mm.; tail, 91-102.5 (97.7); exposed culmen, 6.1-7.5 (6.7); tarsus, 12.5-14.8 (13.4); middle toe, 13-15 (14.1).

Type-Zocality.-Long Island, Bahama Islands.

Geographical distribution.-Bahama Islands. Breeds in the Upper Tropical Zone, north to Abaco Island, and Great Bahama Island; west to Andros Island; south to Great Inagua. Island; and east to Acklin Island, Watling Island, and Eleuthera Island. Reported from the following islands: Abaco, Abaco Keys, Acklin, Andros, Eleuthera, Fortune, Grassy Cay, Great Bahama, Great Inagua, Long, Moraine Cay, New Providence, Southern Andros, Stranger Cay, Sugarloaf Cay, and Watling Island. Winter home unknown.

Remarks.-This race is, in color, except for the posterior lower parts, intermediate between Chordeiles virginianus chapmani and Chordeiles virginianus asemiensis, but is smaller than either. From the latter it differs, in addition to smaller size, in its darker upper surface, the dark brown ground color being more blackish (less grayish), the light mottlings less numerous; and in its more deeply colored inferior surface, the dark brown areas of the anterior portion more blackish, the posterior portion buff instead of nearly or quite white, and with much heavier dark cross-bars.

The female is very similar to the male, but averages lighter, somewhat more brownish (less blackish) above, more brownish (less blackish) on the jugulum, and a little more ochraceous or buffy on the posterior lower parts.

No juvenal or first-autumn specimens have been seen, but these plumages probably present the usual differences.

Individual variation is in character about as in chordeiles virginianus chapmani. The upper parts of both male and female range from blackish, with light markings, much as in Chordeiles virginianus hesperis, to a much lighter ground color considerably more profusely light-mottled, just like Chordeiles virginianus sennetti. The light markings above vary from deep ochraceous buff to pure 
white and to grayish white with but little or no buffy tinge. The posterior lower parts of both sexes and the light throat-patch of the female vary from cream buff or buffy white to ochraceous buff.

No satisfactory division of this race is possible, at least with the material at present available. Birds from Andros, Great Bahama, and other islands appear to be slightly darker above than those from Eleuthera Island, but this may be due to the unevenness of the series. Differences in size, as may be noted from the table of detailed measurements, are equally difficult to correlate with any geographic areas.

This well-characterized race seems to be only a summer resident in the Bahama Islands, from which it disappears in the autumn, but there is no direct clue to its winter home. It probably, however, winters in South America along with the other forms of the species. It is known to breed in July, and probably does so also during May and June.

Specimens examined.-Of this race we have seen altogether 20 examples, from the localities in the Bahama Islands listed below:

Andros Istand.-Wide Opening (June 17, 1890); Grassy Creek (June 28, 1903).

Eleuthera Island.-Governor's Harbor (July 4 and 7, 1903).

Great Bahama Istand.-(July 17, 1904.)

Long Istand.-(July 16 and 17, 1903.)

Moraine Cay.-(July 12 and 13, 1904.)

New Providence Island.-Nassau (May 13, 1897; May 21, 1902.)

Southern Andros Island.-(May 19, 1904.)

Stranger Cay.-(July 8 and 15, 1904.)

Sugar Loaf Cay.-(July 14, 1904.)

Measurcments of specimens of Chordeiles virginianus vicinus.

\begin{tabular}{|c|c|c|c|c|c|c|c|c|c|}
\hline Museum and No. & Sex. & Locality. & Date. & Collector. & $\stackrel{\infty}{9}$ & न्ं & 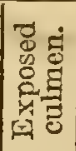 & 窎 & $\overbrace{\substack{0 \\
\hdashline}}^{\infty}$ \\
\hline U.S.N.M. $189689^{1}$.. & Male ${ }^{2 . .}$ & Long Island, & July 16,1903 & J. H. Riley.. & $\underset{172}{m m}$ & $\begin{array}{c}m m \\
100.5\end{array}$ & $m m$. & $\underset{14}{m m}$ & $\operatorname{mm}_{14}$ \\
\hline . M. 1896881. & .. do & 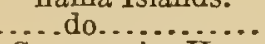 & 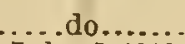 & $d_{0}$ & 163 & 92 & 6.9 & 13.8 & 13.9 \\
\hline IT & 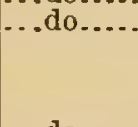 & $\begin{array}{l}\text { Governor's Har- } \\
\text { bor, Eleuthera } \\
\text { Island, Bahama } \\
\text { Islands. }\end{array}$ & July 7,1903 & & 162.5 & 92 & 6.5 & 13.3 & 14 \\
\hline $\begin{array}{l}\text { U.S.N.M. } 1896911 \text {.. } \\
\text { U.S.N.M. } 189824 \text { 1.. }\end{array}$ & $\begin{array}{l}\text {...do... } \\
\text {...do... }\end{array}$ & Eleuthera Island, & .....do........ & ..... do....... & $\begin{array}{l}166 \\
175\end{array}$ & $\begin{array}{l}94.5 \\
97\end{array}$ & $\begin{array}{l}7.2 \\
6.3\end{array}$ & $\begin{array}{l}13.5 \\
14.8\end{array}$ & $\begin{array}{l}13.5 \\
15\end{array}$ \\
\hline$\underset{99450.1}{\operatorname{Am} . \text { Mus. N. H. }}$ & ....do.. & $\begin{array}{l}\text { Southern Andros } \\
\text { Island, Bahama }\end{array}$ & May 19, 1904 & $\begin{array}{l}\text { F. M. Chap- } \\
\text { man. }\end{array}$ & 173.5 & 95.5 & 7.2 & 13 & 13.3 \\
\hline$\underset{54607.1}{\operatorname{Am} . ~ M u s . ~ H . ~}$ & ...do..... & $\begin{array}{l}\text { Wide Opening, } \\
\text { Andros Island, } \\
\text { B a h a ma Is - } \\
\text { lands. }\end{array}$ & June 17,1890 & $\begin{array}{l}\text { J. I. and } \\
\text { A.R. Nor- } \\
\text { throp. }\end{array}$ & 183 & 103 & $\ldots$. & 13 & 13.8 \\
\hline M.C.Z. $40210^{1 .}$ & ...do.. & $\begin{array}{l}\text { Great Bahama Is- } \\
\text { land, Bahama } \\
\text { Islands. }\end{array}$ & July 17,1904 & & 168 & 100 & 6.2 & 13 & 13.8 \\
\hline
\end{tabular}

1 Used in measurement averages on p. 80.

2 Type; original number, 183. 
Measurcments of specimens of Chordeiles virginianus vicinus-Continued.

\begin{tabular}{|c|c|c|c|c|c|c|c|c|c|}
\hline Nuseum snd No. & Sex. & Iocality. & Date. & Collector. & 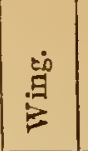 & 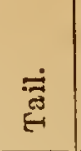 & 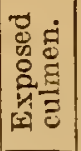 & 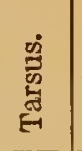 & $\stackrel{0}{0}$ \\
\hline M.C.Z. 402111 .. & Male & $\begin{array}{l}\text { Stranger Cay, } \\
\text { Baha nua Is- }\end{array}$ & July 15,1904 & & $\begin{array}{c}m m . \\
163.5\end{array} \mid$ & $\begin{array}{c}m m . \\
97.5\end{array}$ & $\begin{array}{r}m m . \\
6.5\end{array}$ & $\begin{array}{c}m m \\
13\end{array}$ & $\begin{array}{l}m m . \\
13\end{array}$ \\
\hline $\begin{array}{l}\text { E.A.and O.Bangs } \\
14975.1\end{array}$ & - . do. & $\begin{array}{l}\text { lands. } \\
\text {..do... }\end{array}$ & July 8,1904 & & 175 & 96 & 6.1 & 13 & 14.8 \\
\hline U.S.N.M.189687 ${ }^{1}$. & Female. & Long Island, Ba- & July 17, 1903 & J. I. Riley.. & 168 & 93 & 7.5 & 12.5 & 13.5 \\
\hline U.S.N.M.189825 1.. & ...do. & $\begin{array}{l}\text { Eleuthera Island, } \\
\text { B a ha m a Is - } \\
\text { lands. }\end{array}$ & July 4,1903 & . do. & 167 & 91 & 6.1 & 13.8 & 14.2 \\
\hline U.S.N.M. 1895231 1.. & ... do & .... do........... & July 7,1903 & ....do. & 168.5 & 93 & 6.1 & 14.8 & 14.8 \\
\hline U.S.N & $\ldots$ do $\quad-h$ & $\begin{array}{l}\text { Grassy Creek, An- } \\
\text { dros Island, Ba- } \\
\text { hama Islands. }\end{array}$ & June 28, 1903 & . & 176 & 99 & 6.5 & 14 & 13 \\
\hline$\underset{76562.1}{\operatorname{Am} . ~ M u s . ~ N . ~ H . ~}$ & ... do. & $\begin{array}{l}\text { Nass a u, Ne iv } \\
\text { Providence Is- } \\
\text { land, Bahama } \\
\text { Islands. }\end{array}$ & May 21, 1902 & $\begin{array}{l}\text { F. Mr. Chap- } \\
\text { man. }\end{array}$ & 160.5 & 95 & 6.5 & 13.5 & 14 \\
\hline E.A.and O.Bangs & do & ... do........... & Mray 13,1397 & $\begin{array}{l}\text { C. J. May- } \\
\text { nard. }\end{array}$ & 184.5 & 101 & 6.9 & 13 & 14 \\
\hline $\begin{array}{l}\text { E.A.and O. Bangs } \\
14976.1\end{array}$ & ...do & $\begin{array}{c}\text { Moraine Cay, Ba- } \\
\text { hama Islands. }\end{array}$ & July 13,1901 & & 177.5 & 98 & 6.5 & 12.5 & 13.1 \\
\hline M.C.Z. 40213 I & . . do & ....do............. & July 12,1904 & & 181 & 100 & 7.1 & 14 & 14.8 \\
\hline $\begin{array}{l}\text { M.C.Z. } 40214^{1} \ldots \ldots \\
\text { M.C.Z. } 402121 \text {. }\end{array}$ & $\begin{array}{l}. . \mathrm{dl} \\
. . \mathrm{dc}\end{array}$ & Sugar Loaf Cay, & $\begin{array}{l}\text { July } 13,19 n-1 \\
\text { July } 14,1904\end{array}$ & & $\begin{array}{l}181 \\
168\end{array}$ & $\begin{array}{c}102.5 \\
91\end{array} \mid$ & $\begin{array}{l}7 \\
7\end{array}$ & $\begin{array}{l}13.5 \\
12.5\end{array}$ & $\begin{array}{l}15 \\
14.2\end{array}$ \\
\hline & & $\begin{array}{l}\text { Bahama Is - } \\
\text { lands. }\end{array}$ & & & & & & & \\
\hline
\end{tabular}

1 Used in measurement averages on p. 80.

\section{CHORDEILES VIRGINIANUS MINOR (Cabanis).}

Chordediles minor CaBanis, Journ. f. Ornith., January, 1S56, p. 5 (northern coast of Cuba).

Chordeiles gundlachii LAWrence, Ann. Lyc. Nat. Hist. N. Y., vol. 6, December, 1856, p. 165 (Cuba).

Chars. subsp.- Similar to Chordeiles virginianus vicinus, but wing and tail somewhat shorter; upper parts darker, the light markings less numerous, coarser, and much more tawny; general tone of lower surface darker, because more deeply ochraceous or tawny, particularly on posterior portion.

Iris dark brown; bill dark brown; feet dark brown.

Measurements.-Female: Total length (in flesh), $218.4 \mathrm{~mm}^{2}$

Male: ${ }^{3}$ Wing, 159-174 (average, 168) mm.; tail, 89-97.5 (93.5) ; exposed culmen, 6.1-8.0 (6.6); tarsus, 12.5-14.1 (13.4); middle toe, 13-14.2 (13.9).

Female: ${ }^{4}$ Wing, 160-174.5 (168.7) mm.; tail, 89.5-103 (95.3); exposed culmen, 6.0-7.0 (6.7) ; tarsus, 12-14.1 (13.3); middle toe, $13.1-14.9(13.9)$.

Type-locality.-Northern coast of Cuba.

a Ten specimens, from Cuba.

1 Nine specinens, from Cuba and Porto Rico. 
Geographical distribution.-Greater Antilles. Breeds in the Upper Tropical Zone of Cuba, Jamaica, Haiti, Porto Rico, and the Isle of Pines. Winter home unknown.

Remarlss.-This is the smallest and most deeply tawny or rufescent of all the races of Chordeiles virginianus. It is also the southernmost in distribution. It differs very decidedly from Chordeiles virginianus by reason of its much smaller size; coarser and much more tawny markings on the upper surface; and darker, much more rufescent, tawny, and ochraceous inferior parts.

The female of the present race is considerably more different from the male than is the case in Chordeiles virginianus vicinus. She has the dark areas of the upper parts more brownish (less blackish) than has the male, their light mottlings duller, more ochraceous or tawny; the dark areas of the inferior surface decidedly more rufescent (less blackish); and the posterior lower parts decidedly more ochraceous or tawny.

The first autumn plumage is similar to that of both Chordeiles virginianus virginianus and Chordeiles virginianus chapmani, but the light markings are normally much more deeply tawny. Occasional specimens are, however, more grayish, and scarcely, if at all, distinguishable.

Individual rariation is great, and about the same in both sexes. There are really two fairly distinct color phases, a tawny or rufous and a gray, the latter of which is comparatively rare. Taking these tiro phases as the extremes, the prevailing color of the light markings above in both male and female varies from deep tawny to grayish white and creamy white; the light areas of lower parts from tawny ochraceous to grayish white in the male, and from buff to deep tarny in the female.

Specimens from the Isle of Pines appear to be identical with those from Cuba. The males we have examined from Jamaica have an average longer wing and tail than those from Cuba, but the females show no difference. In color they are all the same, and this apparent size difference would probably disappear in a larger series. How much it is appears in the following table of average measurements:

\begin{tabular}{|c|c|c|c|c|c|}
\hline Localities. & Wing. & Tail. & $\begin{array}{l}\text { Exposed } \\
\text { culmen. }\end{array}$ & Tarsus. & $\begin{array}{c}\text { Middle } \\
\text { toe. }\end{array}$ \\
\hline Ten males, from Cuba..................... & $\begin{array}{c}m m . \\
168\end{array}$ & $\begin{array}{c}m m . \\
93.5\end{array}$ & $\begin{array}{r}m m . \\
6.6\end{array}$ & $\begin{array}{c}m m . \\
13.4\end{array}$ & $\begin{array}{c}m m . \\
13.9\end{array}$ \\
\hline Five males, from Jamaica.... & 174.6 & 94.8 & 6 & 13.2 & 13.9 \\
\hline Eight females, from Cuba....... & 168.1 & 95.3 & 6.7 & 13.5 & 13.9 \\
\hline One female, from Porto Rico...................... & 173 & $\ldots \ldots \ldots$ & 7 & 12 & 13.2 \\
\hline 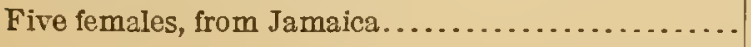 & 168.8 & 95.9 & 6.2 & 13.5 & 13.8 \\
\hline
\end{tabular}


The present race is a summer resident from April to October on all of the islands of the Greater Antilles. There are eggs in the United States National Museum collected from May 9 to July 7, inclusive. Like Chordeiles virginianus vicinus, however, it disappears in autumn, but it probably winters with the Bahama Islands form in South America.

The type of Chordeiles virginianus minor, ${ }^{1}$ which was collected by Dr. Juan Gundlach in Cuba, we have not been able to examine, but there seems to be no doubt that it represents the breeding form of this island, as the original description clearly indicates. The type of Chordeiles gundlachii Lawrence, ${ }^{2}$ from Cuba, which was in the collection of George N. Lawrence, and is now in the American Museum of Natural History, is a typical specimen of Chordeiles virginianus minor in the rufous, or rather tawny, phase. At present it has three old labels, the first of which bears the inscription, in George N. Lawrence' handwriting, "Chordeiles minor Cab. o Cuba"; the second "Chordeiles gundlachii"; and on the reverse, "Type," also in Mr. Lawrence' chirography; and the third, "Chordeiles gundlachi Lawrence of adultus." The name Chordeiles gundlachii should, of course, be synonymized with Chordeiles virginianus minor.

Specimens examined.-Total number 3T, from the following localities in the West Indies:

Cuba.-San Diego de los Baños (Apr. 12, 16, and 18, 1900) ; Holguin (May 31, 1904; June 11, 1904; Aug. 2, 1905).

Isle of Pines.-Nueva Gerona (June 29 and 30, 1900; July 3 and 5, 1900) ; Hospital Spring (1904); Almacigos (Apr. 19, 1904); [no specific locality] (May 25, 1904).

Jamaica.-Hope Gardens, near Kingston (May 28, 1904) ; Phoenix Park, St. Ann Parish (July 25, 1865) ; Great Salt Pond, near Spanishtown (August, 1862); Bath (incubating female, July 7, 1902); Passage Fort, near Spanishtown (June, 1863) ; Mayfield, St. Andrew Parish (Apr. 18, 1879; June 25, 1874) ; Troy, 2,200 feet altitude (June 27, 1904).

Porto Rico.-[No further locality specified.]

${ }^{1}$ Chorderliles minor Cabanis, Journ. f. Ornith., January, 1856, p. 5.

2 Ann. Lyc. Nat. Hist. N. Y., vol. 6, December, 1856, p. $16 \overline{5}$. 
Ifeasurements of specimens of Chordeiles virginianus minot.

\begin{tabular}{|c|c|c|c|c|c|c|c|c|c|}
\hline Museum and No. & Sex. & Locality. & Date. & Collector. & $\stackrel{0}{\mathscr{E}}$ & تีّ & 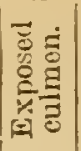 & 胥 & $\mid \begin{array}{l}0 \\
0 \\
0 \\
0 \\
0 \\
0 \\
0\end{array}$ \\
\hline Ius. N. H. & Male & Cuba. & & & ${ }_{171}^{m m}$ & $m m$ & $\begin{array}{r}m m \\
6.5\end{array}$ & $\begin{array}{l}m m . \\
13.2\end{array}$ & $\min _{14}$ \\
\hline $\begin{array}{l}\text { E. A. and O.Bangs } \\
1365 \% .1\end{array}$ & ...do. & Holguin, Cuba. & Aug. 2,1905 & O. Tollin. & 173.5 & 94.5 & 8 & 14 & 14.2 \\
\hline $\begin{array}{l}\text { E.A. and O.Bangs } \\
14930.1\end{array}$ & ...do. & .....do & Mas 31,1904 & do & 166 & 89 & 6.1 & 13 & 13 \\
\hline $\begin{array}{l}\text { E.A. and O.Bangs } \\
13446.1\end{array}$ & ...do. & $\begin{array}{l}\text { Isle of Pines, West } \\
\text { Indies. }\end{array}$ & May 25,1904 & W. R. Zap- & 159 & 89.5 & 6.9 & 13 & 14 \\
\hline M. $1727851 \ldots$ & ...do. & $\begin{array}{l}\text { Nuera Gerona, } \\
\text { Isle of Pines, } \\
\text { West Indies. }\end{array}$ & June 29, 1900 & $\begin{array}{l}\text { W. Palmer } \\
\text { and J. H. } \\
\text { Riley. }\end{array}$ & 166 & 96.5 & 6.5 & 12.5 & 13.5 \\
\hline $\begin{array}{l}\text { U.S.N.M. } \\
\text { U.S.N.M. }\end{array}$ & $\ldots d d$ & $\begin{array}{l}\ldots . d \\
\ldots . . d\end{array}$ & $\begin{array}{l}\text { June } 30,1900 \\
\ldots . . . \text { do...... }\end{array}$ & $\ldots . d$ & $\begin{array}{l}174 \\
170.5\end{array}$ & 97.5 & $\begin{array}{l}6.1 \\
6.2\end{array}$ & 13.5 & $\begin{array}{l}13.8 \\
14.2\end{array}$ \\
\hline 1 & ..c & & ...... do & $\cdots \cdots$ & 165 & 90 & 6.5 & 13.5 & 14 \\
\hline & $\ldots d$ & & .....d & $\ldots$. & 166.5 & 96 & 7 & 14.1 & 14.2 \\
\hline & $\ldots d$ & $\because \ddot{T r}$ & June 27,1904 & $\because \cdot{ }^{d}$. & $\mid \begin{array}{l}16 S \\
171\end{array}$ & $\begin{array}{l}96.5 \\
94\end{array}$ & $\ddot{6} . \dot{s}$ & $\begin{array}{l}13 \\
13\end{array}$ & $\begin{array}{l}17 \\
13.8\end{array}$ \\
\hline U.S. & $\ldots$ d & ardens, Ja- & May $2 S, 1904$ & $\ldots . . d$ & 172.5 & 94 & 6.2 & 13.8 & 15 \\
\hline U.S.N.M. 106159... & ...do. & $\begin{array}{l}\text { Phoenix Park, St. } \\
\text { Ann Parish, Ja- } \\
\text { maica. }\end{array}$ & July 25,1865 & W.T. March. & 176 & 94.5 & 5.7 & 13 & 13 \\
\hline .1 .8 & ... do & .....do & July,- 1865 & $\ldots$. & 178 & 95.5 & 5.3 & 13 & 14. 2 \\
\hline A.N & L do & $\begin{array}{l}\text { Great Salt Pond, } \\
\text { n e a r Spanish- } \\
\text { town, Jamaica. }\end{array}$ & Aug. -, 1862 & 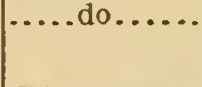 & 175.5 & 96 & 5.9 & 13 & 13.5 \\
\hline U.S.N.M. $172590^{1} .$. & Female. & $\begin{array}{l}\text { San Diego de los } \\
\text { Baños, Cuba. }\end{array}$ & A pr. 12,1900 & $\begin{array}{l}\text { W. Palmer } \\
\text { and J. H. } \\
\text { Riles. }\end{array}$ & 170 & 94.5 & 7 & 13 & 13.1 \\
\hline 41. & $\ldots \mathrm{dc}$ & ..... do & Apr. & 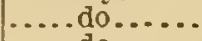 & 168 & 98 & 6.9 & 13 & 13.5 \\
\hline $\begin{array}{l}\text { T.S.N } \\
\text { J.S.N }\end{array}$ & $\ldots d$ & $\because$ Cubs & Apr. 1 & 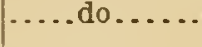 & 166 & 94 & 6.9 & 14.1 & 13.8 \\
\hline $\begin{array}{c}\text { E.A.and O. Bangs } \\
\text { 14932.1 }\end{array}$ & $\ldots d$ & Holguin, Cuba... & June 11,1904 & o. Tollir & $\begin{array}{l}17.5 \\
172\end{array}$ & 100 & $\begin{array}{l}6.3 \\
6.8\end{array}$ & $\begin{array}{l}13.2 \\
13.2\end{array}$ & 14 \\
\hline E.A.and O.Bangs & ...do & $\begin{array}{l}\text { Almacigos, Isle of } \\
\text { Pines. }\end{array}$ & Apr. 19,1904 & $\begin{array}{l}\text { W. R. Zap- } \\
\text { pes. }\end{array}$ & 169 & 93.5 & 6 & 14 & 14.2 \\
\hline $.1727931 \ldots$ & $\ldots \mathrm{dc}$ & $\begin{array}{l}\text { Nuera Gerona, } \\
\text { Isle of Pines, } \\
\text { West Indies. } \\
\text {..do...................... }\end{array}$ & June 30,1900 & $\begin{array}{l}\text { TH. Palmer } \\
\text { and J. H. } \\
\text { Riley. }\end{array}$ & 160 & 89.5 & 6.8 & 13.8 & 14 \\
\hline & & Port & & iv. & 173 & & & 12 & 13. \\
\hline U.S. & d & $\begin{array}{l}\text { Phoenix Park, St. } \\
\text { Ann Parish, Ja- } \\
\text { maica. }\end{array}$ & July 25,1865 & W.T. March. & 171 & 95.5 & 6 & 13.5 & 13.5 \\
\hline 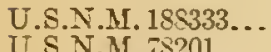 & ...do & Bath, J & July 7,1902 & $\pi$ & 171.5 & 100 & 6.5 & 13.8 & 13.8 \\
\hline & & $\begin{array}{l}\text { Mayfield, St. An- } \\
\text { drew Parish, Ja- } \\
\text { maica. }\end{array}$ & Apr. 18,1879 & E. Newton. & 171.5 & 95 & 6.5 & 13.5 & 14 \\
\hline Am. Mus. & ... d & & June 2 & & 165 & 9 & 6.2 & 13.5 & 13.2 \\
\hline $\begin{array}{l}\text { Am. Mus. N. H. } \\
43 S 40 \text {. }\end{array}$ & . & $\begin{array}{l}\text { Passage Fort, near } \\
\text { Spanish to w } n \text {, } \\
\text { Jamaica. }\end{array}$ & June & ch. & 165 & 93 & 6 & 13.3 & 14.5 \\
\hline
\end{tabular}

1 Used in measurement arerages on p. 82 .

2 Type of Chordeiles gundlachii Lawrence. 


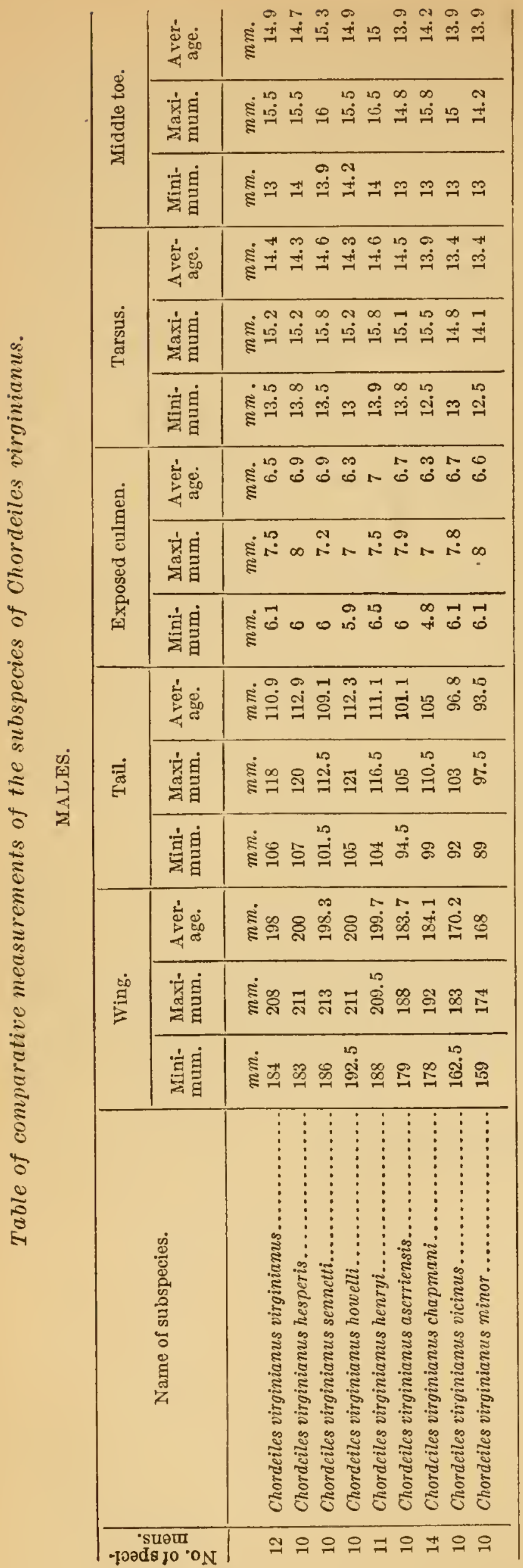

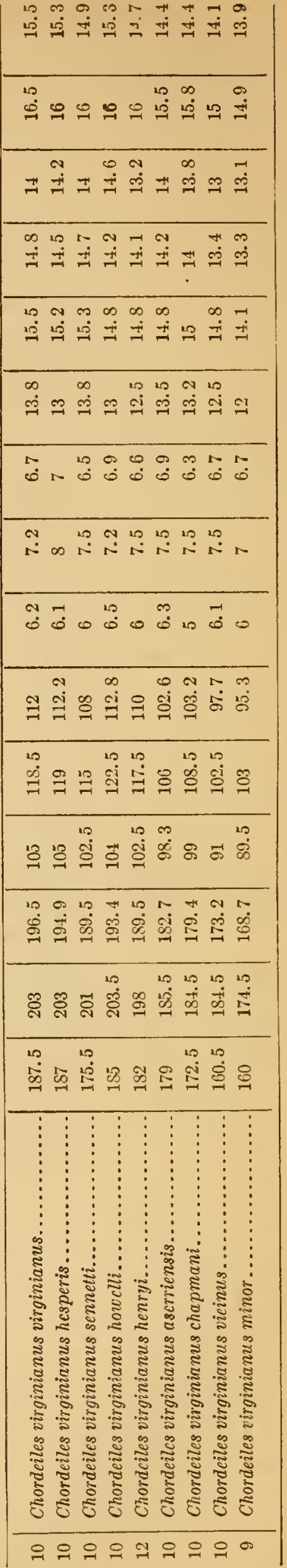


CHORDEILES ACUTIPENIIS (Boddaert).

Caprimulgus acutipennis BoddaerT, Tabl. Planch. Enlum. d'Hist. Nat., 178s, p. 46 (Guiana). ${ }^{1}$

Chars. sp. (adult male).-Interorbital region of skull somewhat narrower than in Chordeiles virginianus; longitudinal ridges on the median portion of frontal bones strongly developed; maxillo-palatines relatively rather narrower and more elongated than in Chordeiles virginianus; vomer rather broader than in Chordeiles virginianus; antero-external processes of the palatines decidedly slender, more so than in Chordeiles virginianus; pterygoids with no decided exterior angle near the anterior end, and the terminal portion approaching the palatine only at the point of articulation; first (ontermost) primary usually shorter than the second; shortest secondary usually reaching or exceeding the tips of the primary coverts; distance from bend of folded wing to end of shortest secondary nearly always greater than from latter point to end of fourth primary (counting from the outermost); tips of most of rectrices usually somewhat squarish; upper surface dark brown or blackish, profusely mottled with white, buff or tawny; tail dark brown, irregularly barred, at least on middle feathers, with white, gray, or buff; wing-quills fuscous, the usually four, sometimes five, outer primaries crossed by a large white spot between the tips of the fifth and eighth primaries, the basal portion of primaries and whole of secondaries and primary coverts with conspicuous buff or ochraceous spots or bars; axillars and under wing-coverts buff or ochraceous, barred with brown; throat of male white; jugulum and breast dark brown, vermiculated and spotted with whitish, buffy or ochraceous; rest of lower surface buff or whitish, barred with dark brown.

Adult female.-Differs from the adult male in much smaller size; smaller, and wholly or largely buff instead of white wing-patch; absence of white subterminal bar on tail ; more whitish or buffy mottling on terminal portion of tail, which, in the male, except for the middle pair of rectrices, is usually plain brown; generally more or less buffy throat-patch, which, however, in some individuals is almost as white as in the male; and average rather more ochraceous lower parts.

First autumn plumage.-This is practically the same in both male and female as that of the adults so far as the contour feathers are concerned, and otherwise differs only in having whitish or buffy tips on the primaries, secondaries, and rectrices. These light tips mostly wear off before the next molt, but usually persist sufficiently, at least on the shortest secondaries, to serve for the discrimination of yearold birds. 
Juvenal plumage.-In this plumage both sexes are decidedly lighter and more closely and evenly mottled than in the adult, particularly above. In the male the upper parts are also more uniform, with more ochraceous or gray and less black; the tail and wing-quills are broadly tipped with buff; the light bars of the tail are more deeply buff; the white throat-patch is more buffy; the lower surface duller, more.ochraceous, more uniform, less distinctly and less broadly barred. The subterminal bar on the tail is white, about as in the adult.

The juvenal female differs from the adult female much as above cietailed for the male, but somewhat less so. She is similar to the juvenal male, but has the light spot on the primaries smaller and more deeply buff or ochraceous buff, instead of white or slightly buffy; the light throat-patch more deeply buff, never whitish; and she lacks the subterminal white bar on the tail.

Very young birds, both male and female, before they are full grown, are above very pale buff, finely and sparingly spotted with black, and vermiculated with silvery gray; and below, pale buff, with narrow widely spaced bar's of dusky or blackish.

Nestling plumage.-Upper surface fawn color, clouded or obscurely mottled with mars brown; lower parts fawn color, unmarked, but paling on the median portion of breast and abdomen.

Seasonal variation.-Of normal seasonal plumage variation not due to molt there is little or none; what there is consists in the occasional browning of the dark areas and the slight reduction of the light markings from abrasion of the feathers.

Molt.-From the fugitive natal plumage the young bird molts directly into the jurenal plumage, growing the while, so that at least by the time, often before, it has attained full size of body and wings, the juvenal plumage is complete. Then by a practically continuous molt, usually in September, it again changes its contour feathers, but retains the remiges and rectrices. The combination plumage of the first autumn is worn apparently until the following summer, when the regular sequence of adult molt is begun.

The adult of this species molts but once a year, usually between the last of July and the middle of September, most individuals chiefly in August, during which period all of the feathers, including remiges and rectrices, undergo a renerval. Subsequently, from January to July, the plumage becomes increasingly worn each month. Some birds are considerably worn even by January, but, like Chordeiles virginianus, they rarely, if ever, become badly tattered.

Individual variation.-In all the races of this species there is great individual variation in both size and color. Such differences of size appear in the tables of detailed measurements; those of color are at 
once evident on comparison of specimens. In adults these color variations consist in the darkness or lightness of the upper surface, due to the brownness or blackness of the dark areas, and particularly to the fineness and amount of the light mottling, together with the whitish, grayish, ochraceous, or tawny hue of these markings; depth or paleness of lower surface, and of its buffy, ochraceous, or tawny tinge; the width of the black bars on the posterior lower surface, and of the light bars on the tail; and the size of the light wing-spot.

In fact, so conspicuous and often coordinated are many of these differences, particularly those affecting the general coloration of upper and lower parts, that they form several more or less welldefined color phases, which are, however, more striking in some of the subspecies than in others. These phases really number four, though two of them are light and dark extremes of the gray and ochraceous, or tawny, phases. They are all more fully treated under Chordeiles acutipennis acutipennis, ${ }^{1}$ in which race they are very well defined. It is interesting to note that, while in Chordeiles virginianus these buffy, ochraceous, or tawny variations are largely geographical, they are in the present species almost wholly individual. The gray and ochraceous phases of this species are almost if not quite as well marked in juvenal birds of all ages as in the adults, a proof, if any were needed, that these color phases are not die to age.

Geographical variation.-To the three subspecies of Chordeiles acutipennis currently recognized, two are now added, making thus five. All the races are wholly or mainly continental, and correspond fairly well to the characteristics exhibited by representatives of other species occupying the same areas. The typical wide-ranging South American Chordeiles acutipennis acutipennis is a small, dark race; the Peruvian Chordeiles acutipennis exilis, small and light; the Yucatan Chordeiles acutipennis micromeris, ${ }^{2}$ of moderate size and rather pale coloration; the Lower California Chordeiles acutipennis inferior, ${ }^{3}$ rather large and of light color; and Chordeiles acutpennis texensis, large and pale. It is noticeable also that the two southernmost forms-Chordeiles acutipennis acutipennis and Chordeiles acutipennis exilis-are the smallest, and that the size increases regularly northward through Chordeiles acutipennis micromeris ${ }^{2}$ and Chordeiles acutipennis inferior, ${ }^{3}$ reaching its maximum in the northernmost race, Chordeiles acutipennis texensis. In color the pale Peruvian

\footnotetext{
${ }^{1}$ See pp. $96-97$.

see p. 100.

${ }^{8}$ See p. 109.
} 
Chordeites acutipennis exilis is much more like the widely separated Tucatan form, Chordeiles acutipennis micromeris, ${ }^{1}$ than like the intervening and undoubtedly close ally, Chordeiles acutipennis acutipennis. Other than this, the geographical variations of this species present no peculiarities.

The five forms here treated under Chordeiles acutipennis are undoubtedly all subspecies, and the three heretofore recognized currently pass as such. The Peruvian Chordeiles acutipennis exilis doubtless intergrades geographically with Chordeiles acutipennis acutipennis. though we have seen no actual intermediates. Although Chordeiles acutipennis micromeris ${ }^{1}$ has in the breeding season no geographical connection with Chordeiles a. acutipennis, its individual variation in both size and color bridges the gap between the characters of these two forms; while the same is practically true of Chordeiles acutipennis micromeris ${ }^{1}$ and the much more widely separated Chordeiles acutipennis exilis. The northern Chordeiles acutipennis texensis passes into Chordeiles acutipennis micromeris ${ }^{1}$ in southern Mexico, intergrading both geographically and individually; and similarly into Chordeiles acutipennis inferior ${ }^{2}$ in southern California and extreme northern Lower California. Actual geographical intermediates are, however, few in the material examined, doubtless from lack of specimens from the particular localities where intergradation takes place; but intermediates due to individual variation are of frequent occurrence.

The characters which serve to separate the several subspecies consist largely in differences of size, principally of wing and tail, sometimes also of exposed culmen, tarsus, and middle toe; the colors and general tone of upper surface and lower parts, light or dark; the width of both the dark bars and the light interspaces on the posterior lower surface; and the width of the light bars on the tail.

Geographical distribution.-The breeding range of Chordeiles acutipennis as a species extends, in South America, from southern Brazil to Venezuela and Colombia, including, as well, the islands of Tobago and Margarita ; also to British Honduras, Guatemala, Mexico, and the southwestern portion of the United States. It winters also in the remaining countries of Central America. The typical race, Chordeiles acutipennis acutipennis, occupies an area in South America approximately twice as great as the combined range of the four other subspecies. Of the latter, Chordeiles acutipennis texensis has a range of considerable extent; but Chordeiles acutipennis exilis and Chor- 
deiles acutipennis inferior ${ }^{1}$ are comparatively local; while Chordeiles acutipennis micromeris ${ }^{2}$ is somewhat restricted in distribution.

The ranges of the two South American forms, Chordeiles acutipennis acutipennis and Chordeiles acutipennis exitis, seem to be practically continuous; but, so far as known, there is a wide gap between the northern breeding limit of Chordeiles acutipennis acutipennis in northwestern Colombia and the nearest point in the summer distribution of Chordeiles acutipennis micromeris ${ }^{2}$ in Guatemala or British Honduras. By all the collecting that has been done in the intervening countries of Central America-Salvador, Honduras, Nicaragua, Costa Rica, and Panama, the last two particularlynot an actual breeding record has been obtained. If the species really does breed in any part of this area it must be very rare. The range of Chordeiles acutipennis texensis is continuous with that of both Chordeiles acutipennis micromeris ${ }^{2}$ and Chordeiles acutipennis inferior. ${ }^{1}$

Zonal distribution.-In South America this species occupies the Lower Tropical Zone of the Neotropical Region; in Mexico the Lower Tropical, Upper Tropical, and Lower Austral zones, and in places part of the Upper Austral Zone; in the United States chiefly the Lower Austral Zone, but also parts of the Upper Austral Zone. Although the details of its zonal affinities are not very well known, particularly in South America, most of the subspecies seem to have fairly definite zonal distribution. Two races, Chordeiles acutipennis acutipennis and Chordeiles acutipennis exilis, are apparently each confined to a single life zone; one, Chordeiles acutipennis texensis, to two zones; and each of the two other forms to three zones. In some cases a zone is not fully, even but little occupied, this being noted principally with regard to the Upper Austral Zone.

Phylogeny.-The South American origin of Chordeiles acutipennis may be taken almost for granted. Furthermore, that Chordeiles acutipennis acutipennis should be considered the primitive and parent form is indicated by its present South American distribution, its extensive range, its uniformity over this wide area, its lack of migration, and the relation of its characters of color and size to those of other subspecies. In western Peru it has been modified, in that more arid climate and consequently changed environment, into Chordeiles acutipennis exilis, a form of approximately the same size but more pallid coloration. The northwestward dispersal of the species has been through Central America and Mexico to the southwestern United 
States. In the last mentioned region there is no evidence that it formerly occupied a greater area than now; while on the other hand it seems at the present time to be, even if slowly, extending its range, particularly in Texas and California. For some reason not apparent it no longer breeds in Central America southeast of Griatemala, which hiatus may have aided in the differentiation of the northern colony. As expected, the Yucatan form, Chordeiles acutipennis micromeris, is most closely allied to the parent race, Chordeiles acutipennis acutipennis, retaining the same tail markings but becoming larger, and otherwise modified by isolation and its more arid habitat. The northernmost race, Chordeiles acutipennis texensis, also of desert environment, is most nearly allied to Chordeiles acutipennis micromeris, ${ }^{1}$ but still more modified, presenting the extreme of differentiation from the parent stock. The Lower Californian Chordeiles acutipennis inferior, ${ }^{2}$ also a desert bird, is merely a depauperate form of Chordeiles acutipennis texensis, thus nodified by semi-isolation and that peculiar but not well-understood inftuence which produces in southern Lower California so many small forms.

Migration.-The migration of Chordeiles acutipennis differs greatly from that of Chordeiles virginianus. Of the five races of the present species, two, Chordeiles acutipennis acutipennis and Chordeiles acutipennis exilis, seem to be entirely sedentary. Another, Chordeiles acutipennis inferior, withdraws only from the more northern portions of the Lower California peninsula to its southern end. Although the comparatively few available specimens of Chordeiles acutipennis micromeris do not permit any careful analysis of its migratory movements, we know enough to show that its route lies through Central America to its winter home in Costa Rica and Panama.

The northern Chordeiles acutipennis texensis has the greatest migration range of all the forms of the species. It passes from the southwestern United States to extreme eastern Panama. Its route both southward and northward seems to be entirely overland, through Mexico and Central America. It appears in spring in the southwestern United States usually some time in April, though during some years in certain localities not until the middle of May, but exceptionally as early as March 21. It leaves this country ordinarily in September, but lingers on rare occasions as late as October 23. The normal migration movement thus extends over about two months during both spring and autumn.

Habits.-In many of its habits Chordeiles acutipennis resembles Chordeiles virginianus. It is, however, more crepuscular, does not have the high, booming flight, and has different notes. It is fond of the chaparral, groves, gravelly or rocky mesas, valleys, slopes, 
canyons, bottomlands, and other kinds of open country. Its flight, though strong and graceful, is usually rather low. Its notes, uttered both on the wing and while the bird is at rest, are peculiar, and difficult of description, some of them not distantly resembling the call of a little owl. This nighthawk is often gregarious, and large numbers sometimes congregate, usually during the migration seasons. Its food consists of lepidoptera and various other insects, captured largely on the wing, though also by hopping after them on the ground.

This species builds no nest, but lays its eggs on the ground, even though bare, hard, stony, or gravelly, and usually in a more or less exposed situation, although sometimes at the base of a bush. One or two broods are reared; and in the United States the earliest recorded date for eggs is April 27, the latest, August 6. The eggs are two in number, pale grayish or whitish, finely dotted and otherwise marked over the whole surface with lilac, various shades of gray, drab, and slate color. The female often remains on the eggs until almost touched.

History.-The earliest account of the species is apparently that of Buffon, ${ }^{1}$ who, in 1779, described the bird from Guiana under the name "L'Engoulevent acutipenne de la Guyane." Upon this description and the accompanying plate by d'Aubenton, ${ }^{2}$ Boddaert in 1783 based his name Caprimulgus acutipennis. ${ }^{3}$ This same subspecies was subsequently diagnosed as new, twice by Gmelin, ${ }^{4}$ and still more recently no less than six times by various other authors. ${ }^{5}$ Not until 1839 was another valid form described, when the bird of (Chile and) western Peru was named Caprimulgus exilis by Lesson. ${ }^{6}$ The same race was later redescribed twice by Tschudi, ${ }^{7}$ and once by Peale. ${ }^{8}$ The Texas bird was made known as Chordeiles texensis by George $\mathrm{N}$. Lawrence in $1856,{ }^{9}$ though at that time its real relationship with Chordeiles acutipennis was not suspected. The two additional subspecies in the present paper result from the separation of the Lower California bird as Chordeiles acutipennis inferior, ${ }^{10}$ and the bird from Yucatan and southern Mexico as Chordeiles acutipennis micromeris. ${ }^{11}$

\footnotetext{
1 Hist. Nat. des Oiseaux, orig. ed., vol. 6, 1779, pp. 547-548.

a Planch. Enlum. d'Hist. Nat., No. 732.

3 Tabl. Planch. Enlum. d'Hist. Nat., 1783, p. 46.

${ }^{4}$ Caprimulgus brasilianus, Syst. Nat., vol. 1, pt. 2, 1789, p. 1031; Caprimulgus acutus, ibid.

- See p. 94.

${ }^{6}$ Rev. Zool., 1839, p. 44.

7 See p. 98.

8 United States Explor. Exped., rol. 8, Mamm. and Ornith., 1848, p. 172.

ann. Lyc. Nat. Hist. N. Y., vol. 6, December, 1856, p. 167.

10 Sce p. 109.

11 See p. 100.
} 


\section{CHORDEILES ACUTIPENNIS ACUTIPENNIS (Boddaert).}

Caprimulgus acutipennis BoddaERT, Tabl. Planch. Enlum. d'Hist. Nat., 1783, p. 46 (Guiana) (based on Crapaud-volant ou Tette-chevre, de la Guiane, D’Aubenton, Planch. Enlum. d'Hist. Nat., No. T32; and L'E'ugoulevent acutipenne de la Guyane, BuffoN, Hist. Nat. des Oisenux [ed. Montbeillard ${ }^{1}$ ], vol. 12. 1780, p. 264; orig. ed., rol. 6.1779 , p. 547 [Guiana]).

[Caprimulgus] brasilianus GMeLIN, Syst. Nat., vol. 1, pt. 2, 17S9, p. 1031 (Brazil).

[Caprimulgus] acutus Gmeis,, Syst. Nat., vol. 1, pt. 2, 1789, p. 1031 (Guiana).

Caprimulgus noitibo Vieillot, Nouv. Dict. d'Hist. Nat., 2 d ed., vol. 10, 1817, p. 241 (Brazil).

C[aprimulgus]. brasilianus VienLlot, Tabl. Encyc. Mêth. Ornith., vol. 2 , 1823, p. 542 (Brazil).

C[aprimulgus]. semitorquatus WIED, Beiträge Naturg. Bras., vol. 3, 1830, p. 330 (Brazil) (nec Caprimulgus semitorquatus Gmelin, qui Lurocalis semitorquatus Auct.).

Chordeiles labeculatus JARDine, Ann. and Mag. Nat. Hist., ser. 1, vol. 18, 1846, p. 118 (Tobago).

[Chordeiles] sapiti Bonaparte, Consp. Gen. Avium, vol. 1, 1850, p. 63 (South America) (ex Natterer MS.).

Caprimulgus stenopterus Pelzeln, Ornith. Bras., 1 Abth., 1868, p. 14, note (Bahia, Brazil).

Chars. subsp.-Size small; lower parts relatively dark and heavily barred; light bars on tail-feathers narrow ; upper parts mostly brownish or buffy, and rather dark.

Description.-Adult male, in the light gray phase, No. 34355, Carnegie Museum; San Felix, Venezuela, June 16, 1910; M. A. Carriker, jr.; original number, 7507 . Upper parts light brownish gray, with in places a slight tinge of buff, particularly on the scapulars, and mottled, vermiculated, and irregularly barred with brownish black, the pileum nearly all brownish black, the scapulars solid black medially, the lower cervix duller and more uniform; tail fuscous, more or less irregularly and rather narrowly barred with cream buff and whitish, these bars on the upper side of tail much mottled and broken with fuscous; a much broader subterminal pure white bar; wing-quills fuscous, all but the outer primaries spotted or barred on both webs with tawny, ochraceous or buff, having also a broad white bar on four outer primaries mostly posterior to the tip of the eighth primary; wing-coverts and tertials mottled, spotted, and vermiculated

1 Thls is the edition of Buffon that Boddaert cites all through his "Table des Planches Enluminéez d'Histoire Naturelle de M. d'Aubenton." The portion of this edition (18 volumes) relating to birds appeared from 1770 to 1785 . In my receut paper on Butorides virescens (Proc. U. \&. Nat. Mus., vol. 42, 1912, pp. 533 and 564), I inadvertently credited two of Boddaert's references to the Deux Ponts edition, which references should, of course, read "ed. Montbeillard." Suckow, however, in his "Anfangsgrunde der theoret. uud angewandt. Naturgeschichte der Thiere," 1797-1801, regularly cites the Deux Ponts edition. Gmelin, in his "Systema Naturae," uses the original quarto edition. 
with white and buffy like the back; edge of wing along the alula mostly buffy or creamy white; lores and supraocular region mixed white and blackish brown; auriculars and postocular region blackish brown, much mixed with tawny ochraceous and a little with white; cheeks, chin, and sides of neck, blackish brown, much mingled with white and buffy; a large triangular patch on throat white; below this a band of dark brown much spotted with tawny ochraceous; breast dark brown, finely mottled and vermiculated with whitish; lower breast cream white, with conspicuous dark brown cross-bars; abdomen, sides, flanks, and crissum, buff or whitish, with conspicuous dark brown cross-bars, these narrower, farther apart, and somewhat broken on lower tail-coverts; lining of wing deep ochraceous buff, barred with dark brown. "Iris brown; feet dusky flesh; bill brownish black."

Iris brown; bill black or brownish black; feet dusky fiesh color or brownish.

Measurements.-Male: Total length (in flesh), 198-203 (average 201) $\mathrm{min} .^{1}$

Male: ${ }^{2}$ Wing, 150.5-172 (average, 163) mm.; tail, 84-102 (93.6); exposed culmen, 4.8-6.8 (5.8); tarsus, 11.5-14 (12.6); middle toe, 12.1-15 (13.6).

Female: ${ }^{3}$ Wing, 147.5-169 (160) mm.; tail, 86.5-99 (92.7); exposed culmen, 4.5-6.1 (5.3) ; tarsus, 11.5-14 (12.7) ; middle toe, 1214.7 (13.4).

Type-locality.-Cayenne, French Guiana. ${ }^{4}$

Geographical distribution.-Northern, central, and central eastern South America. Permanently resident in the Lower Tropical Zone, north to Tobago Island; Margarita Island, Venezuela; Cumana, Caracas, and Encontrados (Zulia), northern Venezuela; and Cartagena, northern Colombia; west to Cartagena in northern, and Rio San Juan Oscuro in western, Colombia; Guayaquil, western Ecuador; Santa Lucia (mouth of Tumbez River), northwestem Peru; and Matto Grosso, central western Brazil; south to Matto Grosso ; and to Itapura and Iguape in Sao Paulo, southeastern Brazil; east to Iguape, Rio de Janeiro, Bahia, Pernambuco, and Para, easter'n Brazil; Cayenne, French Guiana; Surinam; Quonga and Aunai, British Guiana; Trinidad Island; and the island of Tabago.

Remarks. - With present material it is impossible to recognize in South America more than the two current races of this species, Chordeiles acutipennis acutipennis and Chordeiles acutipennis exitis (=pruinosus). Compared with birds from Guiana, those from

\footnotetext{
1 Three specimens.

2 Eleven specimens, from Venezuela and Guiana.

3 Ten specimens, from Venezuela, British Guiana, French Guiana, and Brazil.

1 Designated by Berlepsch and Hartert, Novit. Zool., vol. 9, 1902, p. 90.
} 
Maripa, on the Rio Caura, Venezuela, seem to average somewhat more grayish (less ochraceous) on the light areas of the upper surface, while the dark areas are not quite so brownish. Two specimens from Encontrados (Zulia), Venezuela, are much more blackish above than either the series from Guiana or Maripa; and one from the Rio San Juan Oscuro, Colombia (No. 71705, Amer. Mus. Nat. Hist.), is even darker, and also more ochraceous above and below. None of these color differences, however, appear to be more than individual. Specimens from Cayenne and British Guiana are in color like those from Brazil; and one from Margarita Island, Venezuela, is just the same. Nor am I able to distinguish from Venezuela birds a single example from Guayaquil, Ecuador (No. 21992, Acad. Nat. Sci. Phila). Specimens from different parts of the range of Chordeiles acutipennis acutipennis average as follows:

\begin{tabular}{|c|c|c|c|c|c|}
\hline Localities. & Wing. & Tail. & $\begin{array}{l}\text { Exposed } \\
\text { culmen. }\end{array}$ & Tarsus. & $\begin{array}{l}\text { Middle } \\
\text { toe. }\end{array}$ \\
\hline Nine males, from Venezuela.... & $\begin{array}{l}m m . \\
164.4\end{array}$ & $\begin{array}{c}m m . \\
94.6\end{array}$ & $\begin{array}{c}m m . \\
6.1\end{array}$ & $\begin{array}{l}m m . \\
12.8\end{array}$ & $\begin{array}{c}m m . \\
13.7\end{array}$ \\
\hline Two males, from the Guianas..... & 156.8 & 89 & 4.9 & 12 & 13.1 \\
\hline Three females, from Venezuela. & 159.7 & 93.7 & 6 & 13.7 & 13.9 \\
\hline Five females, from British Guiaua and French Guiana & 157.3 & 90.4 & 4.9 & 12 & 12.9 \\
\hline One female, from Brazil................... & 168.5 & 95.2 & 4.5 & 13 & 14 \\
\hline
\end{tabular}

It will be noticed that the birds from the Guianas average smaller than those from other localities, but this is possibly due to the smallness of the series.

Individual variation in size is very great, as the table of detailed measurements will show. Likewise there is a wide range of color difference, unattributable to sex, age, or season. In some cases the white subterminal tail-bar of the male is practically absent. There are also two, or rather four, styles of plumage, or phases, as they doubtless really are; a gray, and an ochraceous or tawny phase, each of these with a light and dark extreme. All these are connected by various intermediates. These phases are not so strongly marked as the red and gray plumages of Otus asio, but are nevertheless readily recognizable, although birds in the extremes of these phases seem to be uncommon. Gray birds seem to be the more numerous. In the gray phase the upper surface almost entirely lacks rufous and ochraceous, most of the light areas being white or grayish; and the lower parts have the ochraceous confined to the jugulum, and the buff of the remaining inferior area to the posterior portion. In the ochraceous phase the blackish areas above are somewhat more brownish and the light areas mostly tinged with ochraceous or buff; the lower parts are strongly tinged with ochraceous or tawny throughout; and the 
tail-bars are more deeply ochraceous. The light extreme of both gray and ochraceous phases is characterized by a general reduction of the black areas on the upper parts and a consequent increase of light areas, and by narrower black bars on the posterior lower surface. The dark extreme of both phases has much black above and heavier black bars and mottling below.

The full-grown young bird in gray phase first autumn plumage is superficially very similar to the corresponding stage of Chordeiles virginianus hesperis, but it is more finely mottled above, is smaller, and, of course, readily distinguishable by the position of the white or buff patch on the wing-quills.

The earliest name for any form of this species is Caprimulgus acutipennis Boddaert, ${ }^{1}$ which has for its basis the "Crapaud-volant ou Tette-chevre, de la Guiane" of d'Aubenton;" and "L'Engoulevent acutipenne de la Guyane" of Buffon, ${ }^{3}$ both of which apply exclusively to the bird from the Guianas. Berlepsch and Hartert have further restricted the type-locality to Cayenne, French Guiana. ${ }^{4}$ The next name to be applied to this race is Caprimulgus' Zrasilianus Gmelin, ${ }^{5}$ the type-locality of which is Brazil. Should it, therefore, ever become advisable to separate subspecifically the Brazilian bird from that of the Guianas, as is possible on account of its apparently greater size, its name will be Chordeiles acutipennis brasilianus (Gmelin). The remaining synonyms of Chordeiles acutipennis acutipennis need no further elucidation; but it may be well to mention that Caprimulgus himundinaceus, ${ }^{6}$ which usually appears in the synonymy of Chordeiles acutipennis, Mr. C. E. Hellmayr has found to be a distinct species of an entirely different genus. ${ }^{7}$ He considers it a member of the genus Caprimulgus, but the characters he gives in his text and figures show that it without doubt belongs to Mr. Robert Ridgway's new genus Nyctipolus ${ }^{3}$ and should therefore stand as Nyctipolus hirundinaceus (Spix).

Specimens examined.-Thirty-one specimens have been seen, from the following localities:

Brazil.-Bahia; Anjos.

British Guiana.-Aunai (June 7, 1890; May 14 and 20, 1890).

Colombia.-Rio San Juan Oscuro (June, 1898).

Ecuador.-Guayaquil.

1 Tabl. Plancl. Enlum. d'Hist. Nat., 17S3, p. 46.

s Planch. Enlum. d'Hist. Nat., No. 732

${ }^{3}$ Hist. Nat. des Oiseaux [ed. Montheillard], vol. 12, 1780, p. 264 ; orig. ed., vol. 6, 1779, p. 547.

${ }^{4}$ Novit. Zool., vol. 9, 1902, p. 90.

${ }^{5}$ Syst. Nat., vol. 1, pt. 2, 17\$9, p. 1031.

' Spix, Avium Spec. Nov. Bras., vol. 2, 1825, p. 2, pl. 3, fig. 1 (Solimoëns River, Brazil).

${ }^{7}$ See Hellmayr, Abhandl. Math.-Phys. Klasse Königl. Baser. Akad. Wiss., vol. 22, 1906, p. 636 .

${ }^{8}$ Nyctipolus Ridgway, Proc, Biol. Soc. Wash., vol. 25, May 4, 1912, p. 98 (type, Caprimulgus nigrescens Cabanis). 


\section{French Guiana.-Cayenne.}

Veneruela.-Maripa, Rio Caura (Apr. 23 and 24, 1901; Feb. 3, 1903 ; Dec. 28, 1909) ; Margarita Island (July 2, 1895) ; Encontrados, Zulia (Feb. 20 and 24, 1908); San Felix (June 16, 1910).

Measurements of specimens of Chordeiles acutipennis acutipennis.

\begin{tabular}{|c|c|c|c|c|c|c|c|c|c|}
\hline MIuseum and No. & Sex. & Locality. & Date. & Collector. & 常 & 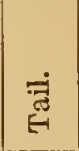 & 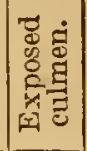 & 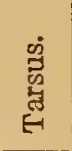 & 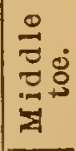 \\
\hline$\underset{331+1.1}{\text { Carnegie }}$ M us. & Male. & $\begin{array}{l}\text { Maripa, Rio } \\
\text { Caura, Vene- } \\
\text { zuela. }\end{array}$ & Dec. 28,1909 & $\begin{array}{l}\text { M. A.C a r - } \\
\text { riker, jr. }\end{array}$ & $\frac{m m}{1 ; 2}$ & $\begin{array}{l}m m . \\
102\end{array}$ & $\left|\begin{array}{c}m m \\
5 . i\end{array}\right|$ & $\begin{array}{l}m m .3 \\
12.3\end{array}$ & $\begin{array}{l}m m . \\
13.5\end{array}$ \\
\hline Am. Mrus. N. H. & ...do. & & Apr. 23,1901 & S. M. Klages & 163 & 95 & 6.1 & 13.5 & 13.5 \\
\hline Am. Mius. N. H. & ...do. & do. & ....do. & ..do. & 168 & 97 & 6.8 & 13.8 & 13.2 \\
\hline Am. Mius. N. H. & ...do. & do & do & 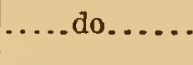 & 150.5 & 81 & 6.1 & 11.9 & 13 \\
\hline $\begin{array}{l}\text { Am. Nius. N. H. } \\
75453.1\end{array}$ & ...do. & do & Apr. 2t, 1901 & do & 162.5 & 91 & 6.5 & 13 & 14.5 \\
\hline $\begin{array}{l}\text { Ficld Misus. N. H. } \\
34535.1 \\
\text { Field Mus. N. H. }\end{array}$ & $\begin{array}{l}\ldots \text {.. do.. } \\
\ldots \text {.. do.. }\end{array}$ & $\begin{array}{l}\text { Encontrados, Zu- } \\
\text { lia, Venezuela. } \\
\ldots . . \text { do................... }\end{array}$ & $\begin{array}{l}\text { Feb. } 24,1908 \\
\ldots \text {...do...... }\end{array}$ & $\begin{array}{l}\text { N. Dearborn } \\
\text {.....do....... }\end{array}$ & $\begin{array}{l}164.5 \\
162.5\end{array}$ & $\begin{array}{l}93.5 \\
91.5\end{array}$ & $\begin{array}{l}6.2 \\
4.8\end{array}$ & $\begin{array}{l}13 \\
14\end{array}$ & $\begin{array}{l}13.5 \\
15\end{array}$ \\
\hline U.S.N.M. $151667^{1}$ & ...do. & Margarita Island, & July 2,1895 & Robin- & 168 & 101 & 6.2 & 11.5 & 13.8 \\
\hline $\begin{array}{l}\text { Carnegie Mr us. } \\
34355.1 \text {. Phila. } \\
\text { A. N. S. Phe }\end{array}$ & $\begin{array}{l}\ldots \text { do } .^{2} . . \\
\ldots \text { do.... }\end{array}$ & $\begin{array}{l}\text { San Felix, Vene- } \\
\text { zuela. } \\
\text { Aunai. British }\end{array}$ & $\begin{array}{l}\text { June } 16,1910 \\
\text { June } 7,1890\end{array}$ & $\begin{array}{l}\text { M. A. Carri- } \\
\text { ker jr. } \\
\text { H. Whitely. }\end{array}$ & $\begin{array}{l}169 \\
156.5\end{array}$ & $\begin{array}{l}96.5 \\
88\end{array}$ & $\begin{array}{l}6.7 \\
4.8\end{array}$ & $\begin{array}{l}12 \\
12\end{array}$ & 13 \\
\hline $\begin{array}{l}50511.1 \\
\text { Am. Mius. N. H. }\end{array}$ & [Male] & $\begin{array}{l}\text { A Guiana. } \\
\text { Guiana............... }\end{array}$ & Jine 7,1890 & & 157 & 98 & $\begin{array}{l}4.8 \\
5\end{array}$ & $\begin{array}{l}12 \\
12\end{array}$ & $\begin{array}{l}14 \\
12.1\end{array}$ \\
\hline $\begin{array}{l}\text { A. N. S. Phila. } \\
\text { 21992. }\end{array}$ & ...do. & $\begin{array}{l}\text { Guayaquil, Ecu- } \\
\text { ador. }\end{array}$ & & W. $\mathrm{s}$. W. & 167 & 99 & 4.5 & 13 & 12 \\
\hline $\operatorname{Am}_{75451.1}$ Mius. N. H. & Female. & $\begin{array}{l}\text { Maripa, Rio } \\
\text { Caura, Vene- }\end{array}$ & Apr. 23, 1901 & S.M. Klages. & 147.5 & 87.5 & 6 & 13.5 & 13 \\
\hline $\begin{array}{l}\text { Field Mrus. N. H. } \\
34536.1\end{array}$ & ...do. & Encontrados, $\mathrm{Zu}$ - & Feb. 20, 1908 & N. Dearborn & 162.5 & 94.5 & 6 & 13.5 & 14 \\
\hline $\begin{array}{l}\text { Field ifus. N. H. } \\
34533.1\end{array}$ & ...do. & ..do. & Feb. 24, 1908 & ....do. & 169 & 99 & 6.1 & 14 & 14.7 \\
\hline A. N. S. Phila. & ...do. & $\begin{array}{l}\text { Aunal, } \\
\text { Guiana. British }\end{array}$ & June 7,1890 & H. Whitely & 162.5 & 92 & .... & 11.5 & 12.5 \\
\hline${ }_{50510.1}$ N. Phila. & ...do. & ......do & do & ... do. & 156.5 & 87 & 4.5 & 13 & 14 \\
\hline A. N. S. Phila. & ...do. & ....do.. & ....do... & ...do & 151 & 86.5 & 5 & 12 & 12.8 \\
\hline A. N. S. Phila. & ...do. & ....do.. & May 20, 1890 & . do & 150 & 92.5 & 5 & 11.5 & 12 \\
\hline $\begin{array}{l}\text { Am. Mus. N. H. } \\
43847.1\end{array}$ & [Female] & $\begin{array}{l}\text { Cayenne, French } \\
\text { Guiana. }\end{array}$ & & & 160.5 & 94 & 5 & 12 & 13 \\
\hline$\underset{43349.1}{\text { Am. Mus. N. H. }}$ & ...do. & Bahi & & $\begin{array}{l}\text { A. de La- } \\
\text { cerda. }\end{array}$ & 168.5 & 95.2 & 4.5 & 13 & 14 \\
\hline $\begin{array}{l}\text { A. N. S. Phila. } \\
\text { 21991.1 }\end{array}$ & ...do. & South America & & & 166 & 99 & 6 & 12.7 & 13.5 \\
\hline
\end{tabular}

1 Used in measurement averages on p. 95. 2 Specimen described on p. 94.

\section{CHORDEILES ACUTIPENNIS EXILIS (Lesson).}

Caprimulgus exilis Lesson, Rev. Zool., 1839, p. 44 (Chile).

C[aprimulgus]. pruinosus 'TschUd, [Wiegmann's] Arehiv fiir Naturg., 1844, p. 268 (Peru) (Lichtenstein MIS.).

Ch[ordiles]. semitorquatus Tschunr, Untersuch. Fauna Permana. Ornith., 1846, p. 130 (text to plate) (Peru).

C[hordiles]. prumosus [err. typ. pro Chordiles pruinosus] Tsciud, Untersuch. Fauna Peruana, Ornith., 1846, p. 130.

Chordeiles peruviamus PEALE, United States Explor. Exped., vol. S, Mamm. and Ornith., 184S, p. 172 (Callao, Peru). 
Chars. subsp.-Similar to Chordeiles acutipennis acutipennis, but upper surface paler and averaging rather less grayish, more brownish in general effect; lower parts paler, the dark bars of a lighter brown, somewhat narrower, and noticeably farther apart with consequently broader white interspaces; light bars on tail broader and on under side averaging paler'; chest and jugulum lighter.

Measurements.-Total length (in flesh), 195-208 mm.; extent of wing, $457-488$.

Male: ${ }^{1}$ Wing, 155-162 (average, 158.5) mm.; tail, 95-96.5 (95.8); exposed culmen, 4.2-4.3 (4.3); tarsus, 13.7-14.3 (14); middle toe, $12.3-12.8$ (12.6).

Type-Zocality.-Northern Chile.

Geographical distribution.-Permanently resident in the Lower Tropical Zone of the Pacific slope of central South America, north to Callao and Lima, central western Peru, and south, probably, to northern Chile.

Remarks.-This race is almost unique in its paleness below, which is due to the width of the light interspaces and to their whiteness. An unfortunately small series has been available, but the subspecies is evidently a good one, though it occupies a very restricted geographical area. A single juvenal male skin of ancient make, said to be from Bolivia, was probably obtained somewhere within the present confines of Chile, though the territory may have owed allegiance to Bolivia when this specimen was procured.

The first autumn plumage of Chordeiles acutipennis exilis is similar to that of Chordeiles acutipennis acutipennis in the gray phase, but is much paler, more silvery above; lighter, more grayish, and more finely vermiculated on the jugulum. In color. of both upper and lower parts it is almost exactly like first autumn Chordeiles virginianus sennetti, though slightly more buffy on the posterior portion of the rentrai surface, and, of course, smaller, with the light spot on the wing-quills nearer their ends.

This race is commonly known as Chordeiles acutipennis pruinosus, ${ }^{2}$ but an earlier name is found in Caprimulgus exilis of Lesson. ${ }^{3}$ This without any reasonable doubt is applicable to the pale bird from Peru; and the main reason for its rejection hitherto has been its type locality of "Chile." The northern part of this country is still imperfectly known ornithologically, and the occurrence of this bird there is at least probable, even within what was formerly the northern boundary of that country. At any rate, the description is a good

\footnotetext{
1 Two specimens, from Peru.

2 Caprimulgus pruinosus Tschudi, [Wiegmann's] Archiv für Naturg., 1844, p. 268 (Peru) (Lichtenstein MS.).

${ }^{3}$ Rev. Zool., 1S39, p. 44.
} 
one, and the name is tenable even if the assigned type-locality be erroneous.

Specimens examined.-Four specimens seen, from the localities below:

"Bolivia." 1-[No further locality specified.]

Peru._Lima; Callao.

Measurements of specimens of Chordeiles acutipennis exilis.

\begin{tabular}{|c|c|c|c|c|c|c|c|c|c|}
\hline Museum and No. & Sex. & Locality. & Date. & Collector. & $\stackrel{\dot{0} 0}{E}$ & 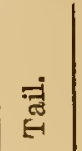 & 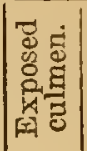 & 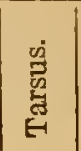 & 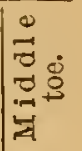 \\
\hline $\begin{array}{l}\text { U.S.N.M. } 140262 \\
\text { U.S.N.M. } 399358\end{array}$ & $\begin{array}{l}\text { Male.. } \\
\text {...do.. }\end{array}$ & $\begin{array}{l}\text { Callao, Peru. } \\
\text { Lima, Peru... }\end{array}$ & & $\begin{array}{l}\text { T. R. Peale } \\
\text { W.S. Churcl }\end{array}$ & $\begin{array}{l}\mathrm{mm} . \\
102 . \\
155 .\end{array}$ & $\begin{array}{l}m m . \\
95 \\
96.5\end{array}$ & $\begin{array}{r}m m . \\
4.2 \\
4.3\end{array}$ & \begin{tabular}{|c|}
$m m$. \\
13.7 \\
14.3
\end{tabular} & $\begin{array}{l}m m . \\
12.3 \\
12.8\end{array}$ \\
\hline
\end{tabular}

2 Used in measurement averages on p. 99.

CHORDEILES ACUTIPENNIS MICROMERIS, new subspecies.

Chars. subsp.-Resembling Chordeiles acutipennis acutipennis, but larger; upper parts not so dark; lower surface paler throughout, the chest and jugulum of a lighter brown, the brown bars on posterior portion lighter and somewhat narrower, the white interspaces wider, particularly on anal region; white subterminal bar on rectrices of male averaging wider.

Description.-Type, adult male, No. 213142, U.S.N.M.; Xbac, Yucatan, Mexico, April -, 1910; George F. Gaumer; original number, 289A. Upper parts light brownish gray, with a more or less evident tinge of buff, particularly on the scapulars, and mottled, vermiculated, and irregularly barred with brownish black, the pileum nearly all brownish black, the scapulars more or less solid black medially, the lower cervix duller and more uniform; tail-feathers fuscous, more or less irregularly and rather narrowly barred with cream buff and whitish, these bars on the upper side of tail much mottled and broken with fuscous; a much broader subterminal pure white bar; wing-quills fuscous, all but the outer primaries more or less spotted or barred on both vanes with tawny, ochraceous or buff, having also a broad white bar on four outer primaries mostly posterior to the tip of the eighth primary; wing-coverts and tertials mottled, spotted, and vermiculated with white and buffy, much like the back; edge of wing along the alula mostly buffy or creamy white; lores and supraocular region mixed white and blackish brown; auriculars and postocular region blackish brown, much mixed with tawny ochraceous, and a little with white; chin buffy grayish, the posterior lateral portion heavily marked with dark brown; cheeks

${ }^{1}$ Doubtless from some locality now within the boundary of Chile. 
and sides of neck blackish brown, much mingled with white and buffy; a large triangular patch on throat white; below this a band of dark brown, much spotted with ochraceous buff; breast dark brown, finely mottled and vermiculated with whitish; lower breast cream white, with conspicuous dork brown cross-bars; abdomen, sides, flanks, and crissum, ochraceous buff, with conspicuous dark brown cross-bars, these narrower, farther apart, and somewhat broken on lower tail-coverts; lining of wing deep ochraceous buff, barred with dark brown.

Iris dark brown; bill brownish; feet dull brownish.

Measurements.-Male: Total length (in flesh), $200 \mathrm{~mm} .^{1}$

Male: ${ }^{2}$ Wing, 161.5-176 (average, 169.4) mm.; tail, 92.5-102.5 (99.1) ; exposed culmen, 5.0-6.2 (5.7); tarsus, 12.5-13.8 (13.3) ; middle toe, 14-14.7 (14.4).

Female: ${ }^{2}$ Wing, 158.5-168 (162.1) mm.; tail, 90-98.5 (94.4); exposed culmen, $5.0-6.5$ (5.8) ; tarsus, 12-14 (13.1); middle toe, 13-15.3 (14.1).

Type-locality.-Xbac, Yucatan, Mexico.

Geographical distribution.-Central America and southern Mexico. Breeds in the Lower Tropical, Upper Tropical, and Lower Austral zones of Guatemala, British Honduras, Yucatan, and other parts of sonthern Mexico: north to Rio Lagartos, and Merida, Yucatan; Campeche, Campeche; Montecristo, Tabasco; Pelenque, Chiapas; and San Mateo, Oaxaca; northwest along the Pacific slope of Mexico to Colima; Zapotlan and Atemajac (near Guadalajara), Jalisco; south to Tuxtla Gutierrez, and San Bartolomé, Chiapas; and Coban, Guatemala; east to British Honduras; and Mujeres Island, eastern Yucatan. In migration southeast through Honduras, Nicaragua, and Costa Rica, to Gatun, in the Canal Zone, Panama. Winters in Panama and Costa Rica, possibly also in other and more northwestern parts of Central America. Not known from South America.

Remarks.-This form differs from Chordeiles acutipennis exilis in larger size; rather darker lower parts, the white interspaces on posterior portion being narrower; somewhat darker, more brownish general effect of the upper surface; and in darker, more ochraceous or buffy (less whitish) light bars on the under side of the tail.

Specimens from Costa Rica and Nicaragua and one from Panama (Gatun, Canal Zone, No. 207668, U.S.N.M.) appear to be exactly the same as those from Yucatan and Chiapas, and are doubtless immigrants, as there seems to be no breeding record of this species for Panama, Costa Rica, Nicaragua, Honduras, or Salvador. 
Breeding birds from Yucatan and Campeche represent the extreme differentiation of this subspecies. Those from southern Chiapas, from Guatemala, and southern Oaxaca, Mexico, are intermediate in size between Chordeiles acutipennis micromeris and Chordciles acutipennis texensis, though in other respects like the former. A single female from Atemajac, Jalisco, near Guadalajara (No. 281892, U.S.N.M.), looks just the same as these intermediate birds from Oaxaca and Chiapas, and is the basis for extending the range of the present subspecies to Jalisco. This is probably correct, though the possibility, of course, exists that this individual is not representative of the birds breeding in Jalisco. Comparative average measurements of specimens from different localities are as below:

\begin{tabular}{|c|c|c|c|c|c|}
\hline Localities. & Wing. & Tail. & $\begin{array}{l}\text { Exposed } \\
\text { culmen. }\end{array}$ & Tarsus. & $\begin{array}{l}\text { Middle } \\
\text { toe. }\end{array}$ \\
\hline Seven males, from Yucatan... & $\begin{array}{l}m m . \\
169.4\end{array}$ & $\begin{array}{l}m m . \\
99.1\end{array}$ & $\begin{array}{c}m m . \\
5.7\end{array}$ & $\begin{array}{l}m m . \\
13.3\end{array}$ & $\begin{array}{l}m m \\
14.4\end{array}$ \\
\hline Two males, from Chiapas (Mexico), and Guatemala.. & 178.5 & 104.3 & 5.6 & 13.3 & 15.3 \\
\hline Two males, from Costa Rica and Panama........... & 167.8 & 99 & 6.5 & 13.8 & 14.8 \\
\hline Seven females, from Yucatan . ..................... & 162.1 & 94.4 & 5.8 & 13.1 & 14.1 \\
\hline One fomale, from Campeche..................... & 163.5 & 91.5 & 5.8 & 14 & 15 \\
\hline Two females, from Chiapas and Jalisco, Mexico...... & 168.8 & 100 & 6 & 12.9 & 13.1 \\
\hline
\end{tabular}

In this Yucatan race there exist the same four adult plumage phases as in Chordeiles acutipennis acutipennis.

Specimens examined.-Of this race 25 examples have been handled, from the stibjoined localities:

Campeche.-Campeche (June 8, 1900).

Chiapas.-Tuxtla Gutierrez (May 26, 1904) ; San Bartolomé (Mar. $24,1904)$.

Jalisco.-Atemajac (north of Guadalajara) (May 28, 1892).

Oaxaca.-San Mateo (Aug. 5, 1869).

Yucatan.-Rio Lagartos (Apr. 10, 14, 18, and 20, 1893), Mujeres Island (Mar. 24, 1901); Merida (June 19, 1865); Chichen Itza (Apr. 2, 1904); Izamal (June, 1905); Xbac (April, 1910).

Costa Rica.-San José (Sept. 10, 1883; Oct. 29, 1891) ; Pigres (Mar. 4 and 11, 1905).

Guatemala.-Lake Atitlan (Apr. 8, 1906).

Honduras.-Truxillo (Sept. 30, 1887).

Nicaragua.-San Geronimo, Chinandega (Mar. 25, 1904).

Panama.-Gatun, Canal Zone (Jan. 11, 1911). 
Iensuremcnts of specimens of Chordeiles acutipennis micromeris.

\begin{tabular}{|c|c|c|c|c|c|c|c|c|c|}
\hline Mliseum and No. & Sex. & Locality. & Date. & Collector. & $\stackrel{i 0}{:}$ & בี่ & 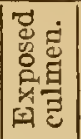 & 节 & ${ }_{0}^{0}$ \\
\hline U.S.N.M. 213142 I. & [Male $]^{2}$ & $n$, & $\Lambda_{\mathrm{pr}}-\mathrm{-}, 1910$ & $1-$ & $\begin{array}{c}m m \\
169\end{array}$ & $\begin{array}{l}m m \\
101\end{array}$ & $\begin{array}{r}m m . \\
5.8\end{array}$ & $\begin{array}{l}m m \\
13.5\end{array}$ & $\begin{array}{l}m m \\
14.7\end{array}$ \\
\hline$F \quad G \approx u m o r$ & Male & ....do.... & ...do. & & 168 & 102.5 & 5.5 & 12.5 & \\
\hline F.Gau & & & do & do & 169 & 96.5 & 6.2 & 12.8 & \\
\hline G. $\underset{289 \dot{B}, 1}{\text { F }}$ a u mer & $\mathrm{M}$ & $\ldots$ & 10 & & 167 & 99 & 5.5 & 13.5 & \\
\hline $\begin{array}{l}\text { E.A. and O. Bangs } \\
4419.1\end{array}$ & ... do & Rio Lagartos, Yu- & Apr. 14, 1893 & W.W.Brown, & 161.5 & 92.5 & 5 & 13.8 & 14.7 \\
\hline 1. $167421^{1}$. & ...do. & & Mar. 24, 1901 & $\begin{array}{l}\text { E.W. Nelson } \\
\text { and E. A. }\end{array}$ & 175 & 101 & 5.8 & 13.5 & 14 \\
\hline U.S.N.M. $130205^{1}$. & [Mal & $\begin{array}{l}\text { ico. } \\
\text { Yucatan........ }\end{array}$ & & G. F. Gau- & 176 & 101.5 & 6 & 13.8 & 14 \\
\hline $\begin{array}{l}\text { Field Mus. N. H. } \\
22582 \text {. }\end{array}$ & Male. & $\begin{array}{c}\text { Lake Atitlan, } \\
\text { Guatemala. }\end{array}$ & Apr. 8,1906 & N.Dearborn & 178 & 103.5 & 5.1 & 13 & 15 \\
\hline U.S.N.M. 193879... & ...do. & $\begin{array}{l}\text { San Bartolomé, } \\
\text { Chiapas, Mex- }\end{array}$ & Mar. 24, 1904 & $\begin{array}{l}\text { E. W. Nelson } \\
\text { and E.A. }\end{array}$ & 179 & 105 & 6 & 13.5 & 15.5 \\
\hline U.S.N.M. 20766S... & ...do & Gatun, $\mathrm{Ca}$ & Jan. 11,1911 & E. A. Gold- & 167 & 101 & 6.8 & 14.5 & 15.1 \\
\hline $\begin{array}{l}\text { E.A.and O. Bangs } \\
16930 \text {. }\end{array}$ & 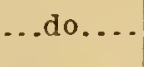 & $\begin{array}{l}\text { San José, Costa } \\
\text { Rica. }\end{array}$ & Sept. 10,1883 & $\begin{array}{l}\text { C. } F \text {. Under- } \\
\text { wood. }\end{array}$ & 168.5 & 97 & 6.1 & 13 & 11.5 \\
\hline & Female. & $\begin{array}{l}\text { Izamal, Yucatan, } \\
\text { Mexico. }\end{array}$ & June-, 1905 & $\begin{array}{l}\text { G. F. Gau- } \\
\text { mer. }\end{array}$ & 162 & 94 & 6 & 12.5 & \\
\hline $\begin{array}{l}\text { G. F. Gaumer } 2881 . \\
\text { Field Mus. N. H. }\end{array}$ & $\ldots d$ & Rio La & Apr. & $\ddot{\mathrm{w}} \cdot \mathrm{w}$. & $\begin{array}{l}161 \\
168\end{array}$ & $\begin{array}{l}98.5 \\
97.5\end{array}$ & $\begin{array}{l}5 \\
6\end{array}$ & $\begin{array}{l}12 \\
13.5\end{array}$ & 14.3 \\
\hline 13247.1 & & catan, Mexico. & $\sin 20.000$ & & 11505 & 1.0 & & & \\
\hline $\begin{array}{l}\text { E. A. and } \\
4418.1\end{array}$ & & 7 & & & 158 & 92.5 & 5.2 & 14 & 15.3 \\
\hline$\underset{43854.1}{\operatorname{Am} . ~ M u s . ~ N . ~ H . ~}$ & ...do. & Yucatan, Mexico. & & $\begin{array}{l}\text { G. F. Gau- } \\
\text { mer. }\end{array}$ & 163.5 & 94.5 & 6 & 14 & 14 \\
\hline U.S.I & [Female] & Izamal, Yucatan, & June,- 1905 & & 162 & 93.5 & 6.5 & 13 & 14 \\
\hline $\begin{array}{l}\text { U.S.N.M. } 13020{ }^{1} \text {. } \\
\text { U.S.N.M. } 166707 \text {. }\end{array}$ & Fem & $\begin{array}{l}\text { Yucatan, Mexico. } \\
\text { Campeche, Cam- } \\
\text { peche, Mexico. }\end{array}$ & June 8,1900 & $\begin{array}{c}\text { E. W. Nelson } \\
\text { and E. A. }\end{array}$ & $\left|\begin{array}{l}160 \\
163.5\end{array}\right|$ & $\begin{array}{l}90 \\
91.5\end{array}$ & $\begin{array}{l}6 \\
5.8\end{array}$ & $\begin{array}{l}13 \\
14\end{array}$ & $\begin{array}{l}13 \\
15\end{array}$ \\
\hline U.S.N.M. 19 & $\ldots$.. do & Tux & May 26,1904 & ....... & 170.5 & 97.5 & 6 & 12.8 & 12.8 \\
\hline U.S.N.M. 154757. & $\ldots d$ & $\begin{array}{l}\text { A temajac, Jalisco, } \\
\text { Mexico. }\end{array}$ & May 28,1892 & do & 167 & 102.5 & 6 & 13 & 13.3 \\
\hline
\end{tabular}

1 Used in measurement averages on p. 101.

2 T spe.

\section{CHORDEILES ACUTIPENNIS TEXENSIS Lawrence.}

Chordeiles texensis Lawrence, Ann. Lyc. Nat. Hist. N. I., rol 6, December, 1856, p. 167 (Texas).

Chars. subsp.--Iike Chordeiles acutipennis inferior, ${ }^{3}$ but larger.

Iris bluish black; bill black; feet gray or " purplish."

Measurements.-Male: Total length (in flesh), 215.9-248 (average, $230.2) \mathrm{mm} .{ }^{4}$ extent of wing, 520.7-581 (555.7).5

Female: Total length (in flesh), 215.9-228.6 (221.2); ${ }^{\text {i extent of }}$ wing, 514.4-552.5 (532.6). ${ }^{7}$

\footnotetext{
${ }^{3}$ See p. 109.

4 'Thirty-two specimens.

5 Twenty-five specimens.

6 Eighteen specimens.

7 Eleven specimens.
} 
Male: ${ }^{1}$ Wing, 173-192 (average, 183.4) mm.; tail, 104-119 (111.6); exposed culmen, 5.0-6.8 (5.9) ; tarsus, 13-15 (14) ; middle toe, 13-15 (14.2).

Female: ${ }^{1}$ Wing, 168.5-180 (175) mm.; tail, 102-110 (106.1); exposed culmen, 5.1-7.0; (6.0) ; tarsus, 12.5-15.2 (13.5); middle toe, $13-15.8$ (14.2).

Type-locality.-Ringgold Barracks, ${ }^{2}$ near Rio Grande City, Texas.

Geographical distribution.-The southwestern United States, Mexico, and all of Central America. Breeds in the Lower Austral, Upper Austral, and Upper Tropical zones of the southwestern United States, northern and central Mexico (excepting southern Lower California) : north to Kerrville and Pecos City, middle Texas; Alamagordo, Deming, and Lone Mountain (Grant County), southern New Mexico; the Santa Catalina Mountains, southeastern Arizona; Fort Verde, central Arizona; Beaverdam, northwestern Arizona; St. George, southwestern Utah; Virgin Valley, Vegas Valley, and Ash Meadows, southern Nevada; Bishop (Owens Valley), Chinese Camp (Tuolumne County), Marysville, Winslow (Glenn County), and Ukiah (Mendocino County), central California; west to Ukiah, Paicines (San Benito County), Ventura, San Pedro, San Diego, and 6 miles west of Mountain Spring, western California; Colorado River opposite the mouth of Hardy River, northwestern Sonora; Rancho Baillon, Papasquiaro, and Durango, western Durango; Rosario, southern Sinaloa; Chicalote, central Aguas Calientes; and Guanajuato, Guanajuato; south to Chimalpa (Valley of Mexico), Mexico; Puente de Ixtla, southern Morelos; and San Baltazar, Puebla; east to Jalapa, central western Vera Cruz; Alta Mira and Matamoros, eastern Tamaulipas; Brownsville, Corpus Christi, and Port O'Connor, central southern Texas. Winters regularly in central and southern Mexico, and in all of Central America: north to Chacala, Durango, rarely to Phoenix, Arizona ${ }^{3}$ west to Manzanillo, Colima; east to Orizaba, Vera Cruz, and Cozumel Island, Yucatan, in Mexico; and southeast through Guatemala, Honduras, Salvador, Nicaragua, Costa Rica, and Panama, to Cana, eastern Panama.

Remarks.-The present race differs from Chordeiles acutipennis micromeris in considerably larger size, broader light tail-bars, and rather paler, rather more brownish tone of the upper surface. It is much larger than Chordeiles acutipennis acutipennis, with broader light tail-bars, and is paler, more grayish, both above and below. The juvenal plumage is identical with that of Chordeiles acutipennis inferior hereinafter described. ${ }^{4}$

${ }^{1}$ Fifteen specimens, from 'Texas, Arizona, and California.

a IIere for the first time definiteiy restricted to this locality.

3 Taken, December 27, 1897.

- See p. 110. 
With large series of specimens for comparison from California, Arizona, New Mexico, and Texas, no geographical differences are observable, and the birds from all these areas evidently belong to the same subspecies. The apparently smaller size of the Texas males in the measurements given below is due to the smallness of the series. Birds from San Diego, southern California, are somewhat smaller than typical Chordeiles acutipennis texensis, and thus incline toward Chordeiles acutipennis inferior, but they are nearer the present form. Examples from the various geographic areas average in measurements as follows:

\begin{tabular}{|c|c|c|c|c|c|}
\hline Localities. & Wing. & Tail. & $\begin{array}{l}\text { Exposed } \\
\text { culmen. }\end{array}$ & Tarsus. & $\begin{array}{l}\text { Middle } \\
\text { toe. }\end{array}$ \\
\hline Five males, from California... & $\begin{array}{l}m m . \\
185.2\end{array}$ & $\begin{array}{l}m m . \\
112.9\end{array}$ & $\begin{array}{r}m m . \\
6\end{array}$ & $\begin{array}{l}m m . \\
13.9\end{array}$ & $m=$ \\
\hline Five males, from Arizona.... & 184.3 & 113.7 & 5.5 & 14.2 & 14.3 \\
\hline Five males, from Texas...... & 180.7 & 108.3 & 6.1 & 13.9 & 14.1 \\
\hline Five females, from California. & 174.8 & 107.3 & 6.1 & 13.6 & 14.3 \\
\hline Five females, from Arizona... & 174.4 & 106.5 & 6.2 & 13.4 & 14.5 \\
\hline Five females, from Texas.. & 175.9 & 104.4 & 5.6 & 13.3 & 13.9 \\
\hline
\end{tabular}

The juvenal and first autumn plumages of this race are apparently identical in color with those of Chordeiles acutipennis inferior. The adults have about the same range of individual variation in color as that race, but are apparently more variable in size. 'The ochraceous phase is like that of $C$ hordeiles acutipennis inferior, less marked than in Chordeiles acutipennis acutipennis; but the light and dark extremes are, however, just as distinct.

The two type specimens, adult and male and female, of Chordeiles acutipennis texensis are in the American Museum of Natural History. They are flat skins, obtained by Capt. J. P. McCown in Texas, and were originally in the collection of George N. Lawrence. The male, which, of course, is to be considered the type, is an abnormally small bird, as its measurements on page 109 show. It is marked in Lawrence' handwriting on the face of the label: "Chordeiles texensis, Lawr." "Texas" " o a 116;" and on the back of the label: "Type" "Presented by Capt. J.P. McCown." The label of the female is identical save for the sex and number, which read: "q b 116." In color both birds are inseparable from Texas specimens. There seems to be now no way of determining the exact locality at which these specimens were collected; and as it seems desirable to have an exact typelocality, I now designate as such Ringgold Barracks, near Rio Grande City, since this is a locality which Captain McCown is known to have visited. 
The Texas nighthawk is normally only a summer sojourner in the United States, where it appears in March, as a specimen which Dr. E. A. Mearns obtained, March 21, 1894, on the Colorado River at the Mexican boundary attests. It leaves this country in September or October (taken, October 5, 1893, San Bernardino Ranch, Arizona, Dr. E. A. Mearns). It breeds from April to August, and there are eggs in the United States National Museum collected from April 27 to Angust 6, inclusive.

Specimens examined.-Total number, 293, from the localities listed below :

Arizona.-Colorado River, 5 miles north of Laguna (Apr. 21, 24, and 26, 1910) ; Ehrenberg (Mar. 27, 1910) ; Date Creek, south of Fort Whipple (June 5, 1865); San Bernardino Ranch, San Bernardino River, on the Mexican boundary line (Aug. 15 and 23, 1892; Oct. 5, 1893) ; Camp Grant, 40 miles east of Tucson (May 4, 1867) ; Fort Huachuca (May 23, 1892; June 3, 1892; June 15, 1891); Huachuca Mountains (June 3, 1891) ; Yuma (Apr. 5, 1884) ; Beaverdam (May 10, 1891); Fort Mojave (May 13, 1884; May 24, 1861); near San Pedro River in Cochise County (Aug. 15, 1890) ; Tucson (May 5, 1883; May 19, 1906 ; June 2 and 3, 1884; June 8, 1881; June 16, 1891); Calabasas (May 26, 1887) ; Colorado River at Monument No. 204, Mexican boundary line (Mar. 21 and 25, 1894); San Pedro slope, Santa Catalina Mountains, Pinal County (May 20, 1885; June 4, 1885 [3,500 feet altitude]; June 7, 1885 [3,000 feet altitude]); Fort Verde (June 3 and 5, 1885; June 17, 1884; Sept. 20, 1886) ; Charleston, Cochise County (June 21, 1896) ; Catalina Mill (June 21, 1884); Babacomari Creek.

California.-Pasadena (Mar. 31, 1896; Apr. 4, 7, 9, and 29, 1896 ; Apr. 27, 1895; Apr. 21, 24, and 30, 1897; May 2, 1894; June 19, 1897; July 26, 1902; Aug. 4, 1900; Aug. 30, 1906) ; San Fernando Valley, Los Angeles County (May 2, 1899; May 22, 1895) ; Sugarloaf Mountain, 7,500 feet altitude, San Bernardino Mountains (Ang. 5, 1905); Cactus Flat, 6,000 feet altitude, San Bernardino Mountains (Aug. 16, 1905); Cushenbury Springs, 4,000 feet altitude, San Bernardino Mountains (Aug. 9 and 13, 1905); Bodfish (June 17, 1911); Los Angeles (Apr. 14, 1898; May 2, 1897; June 20, 1897) ; San Fernando, Los Angeles County (Apr. 24, 1900; Aug. 14, 1897); Mecca, Riverside County (Apr. 2, 4, 7, and 11, 1908); Tipton, Tulare County (Apr. 26, 1911); Reche Canyon, near Colton (July 23 and 28, 1908); Isabella (July 1, 1911) ; Colorado River opposite Cibola, Arizona (Apr. 3, 1910) ; Dulzura (Apr. 24, 1908; June 29, 1894) ; Colorado River, 5 miles northeast of Yuma (May 3, 1910); Chula Vista, San Diego County (May 27, 1908); Paicines (June 12, 1898; July 10, 1898); Kelso Creek, 3,500 feet altitude, 11 miles south-southeast of Weldon, Kern County (July 6, 1911) ; Alhambra (Apr. 11, 12, and 15, 
1889) ; Riverside (Apr. 10, 1885) ; Point Loma, San Diego County (June 19, 1908) ; San Diego (Apr. 20 and 30, 1885; June 7 and 13, 1892) ; Silsbee, Imperial County (Apr. 6, 1906) ; Riverside County (Apr. 21, 1907) ; Cabazon, Riverside County (May 16, 1908); Alila (June 18, 1903) ; Chowchilla, Merced County (June 27 and 28, 1900); Colorado River at Pilof Knnob (taken with eggs, May 8, 1910); Ash Creek, Owens Lake (May 31, 1891) ; Bishop, in Owens Valley, altitude 4,000 feet (June 29, 1891) ; Coalinga, Fresno County (July 8, 1905); Lone Pine, Owens Valley (June 8, 10, 12, and 13, 1891); Bakersfield (July 19, 1891); Valley Springs (June 3, 1898); Unlucky Lake, San Diego County (Apr. 30, 1894) ; divide of mountains west of Coast Range, near Mexican boundary line, about 6 miles west of Mountain Spring, San Diego County (May 17, 1894); Marysville (July 1, 1891); South Fork of Kern River, 25 miles above Kernville (July 8, 1891) ; Keeler (June 2, 1891) ; Chinese Camp (Apr. 20 and 21, 1891) ; San Bernardino (July 30, 1885) ; Ukiah (Apr. 29, 1889) ; Vallevista, San Jacinto Valley (Sept. 2, 1908) ; Needles (Apr. 28, 1905); Ventura (June 1, 1906); Lanes Bridge, 10 miles north of Fresno (Apr. 12, 1911).

New Mexico.-Eastern foothills of Big Hatchet Mountains (July 20, 1908) ; State College (July 12 and 14, 1913) ; Dog Spring, southern Grant County (June 8, 1892) ; Apache, Grant County (May 17, 1886); Gila River (Sept. 14, 1873); Alamogordo (May 17, 1902); between Alamogordo and Dry Canyon, Otero County (May 7, 1902); 8 miles east of Deming (Sept. 4, 1908).

Texas.-Rio Grande City (Apr. 9, 11, and 16, 1880; June 1, 1891; June 15, 1889); Ringgold Barracks (July); Lomita Ranch, near Hidalgo (Apr. 23 and 26, 1878; May 5, 11, and 12, 1878; July 25 and 31, 1880; Aug. 16, 1880) ; Hidalgo (Apr. 18, 1877; May 5, 1877; May 7, 23, 25, and 27, 1889) ; Pecos City (May 25, 1887) ; eastern base of Chisos Mountains (June 23, 1901); Brownsville (Apr. 18, 1889; Apr. 20 and 21, 1892; July 2, 1892); Fort Hancock (June 9, 12, 18, and 21, 1893; Aug. 15, 1902); Frontera; Rio Grande in Cameron County (Apr. 16, 1886) ; Laredo (May 18, 1866; Sept. 5 and 13, 1866); Marathon (May 18, 1891) ; 15 miles south of Marathon (May 17, 1901) ; 20 miles south of Marathon (May 19, 1901); 65 miles south of Marathon (May 19, 1901) ; near Carrizo (May 19, 1891) ; Comstock (July 26, 1902) ; Langtry (May 1, 1903) ; Del Rio (May 19, 1903) ; Kerrville (May 18, 1910); Ysleta (July 25, 1901) ; Runge (Aug. 28, 1905).

Chihuahua.-Mosquito Springs (May 12, 1892) ; San Diego (Apr. 21 and 24, 1891; June 5, 1891) ; near Colonia Garcia (July 15 and $16,1899)$.

Colima.-Plains of Colima (Jan. 14 and 15, 1890); Manzanillo (Jan. 26, 1892). 
Durango.-Rancho Baillon, northwestern Durango, 7,800 feet altitude (May 9, 1903).

Guanajuato.-Guanajuato.

Jalisco.-La Barca (Jan. 4, 9, 17, and 19, 1903; Nov. 22 and 25, 1899 ; Dec. 2, 1899); Ocotlan (Jan. 4, 1903).

Lower California.-Carrizo Valley (Apr: 19, 1893); mouth of Hardy River (Apr. 2, 1905); Seven Wells, Salton River (Apr. 10, 1894).

Michoacan.-Patzcuaro (Dec. 22, 1891).

Morelos.-Cuernavaca (Jan. 3, 1893) ; Puente de Ixtla (June 6, 1903).

Nuevo Leon.-Montemorelos (May 20, 1889) ; Monterey (Apr. 24 and 27, 1889); Linares (Apr. 17, 1891); Santa Catarina (April, 1853).

Oaxaca.-Santa Efigenia (Jan. 3 and 12, 1869).

Sinaloa.-Escuinapa (Dec. 28, 1903); Mazatlan.

Sonora.-Colorado River opposite mouth of Hardy River (Mar. 28, 1894) ; San Marcial (Nov. 10, 1905).

Tamaulipas.-Rio Cruz (June 19, 23, and 30, 1909; July 7, 20, and 21, 1909) ; Santa Leonor (Apr. 14, 15, and 17, 1909); Montelunga (Apr. 27, 1909; and May 1, 1909); Mier (May 5, 1891).

Tepic.-Maria Madre Island, Tres Marias Islands (May 5, 1897).

Vera Cruz.-Jalapa (Apr. 2, 1897); Orizaba (Jan. 25, 1894).

Costa Rica.-Bolson (Dec. 25, 1907); El Rio Ciribí (Jan. 25, 1868 ) ; Limon (Nov. 28, 1896) ; Pigres (Mar. 3 and 10, 1905).

Guatemala.-Dueñas (Feb. 1, 1860).

Nicaragua.-San Juan de Nicaragua.

Panama.-Cana (Mar. 10, 1912).

Salvador.-La Union (January, 1864).

Measurements of specimens of Chordciles acutipennis texensis.

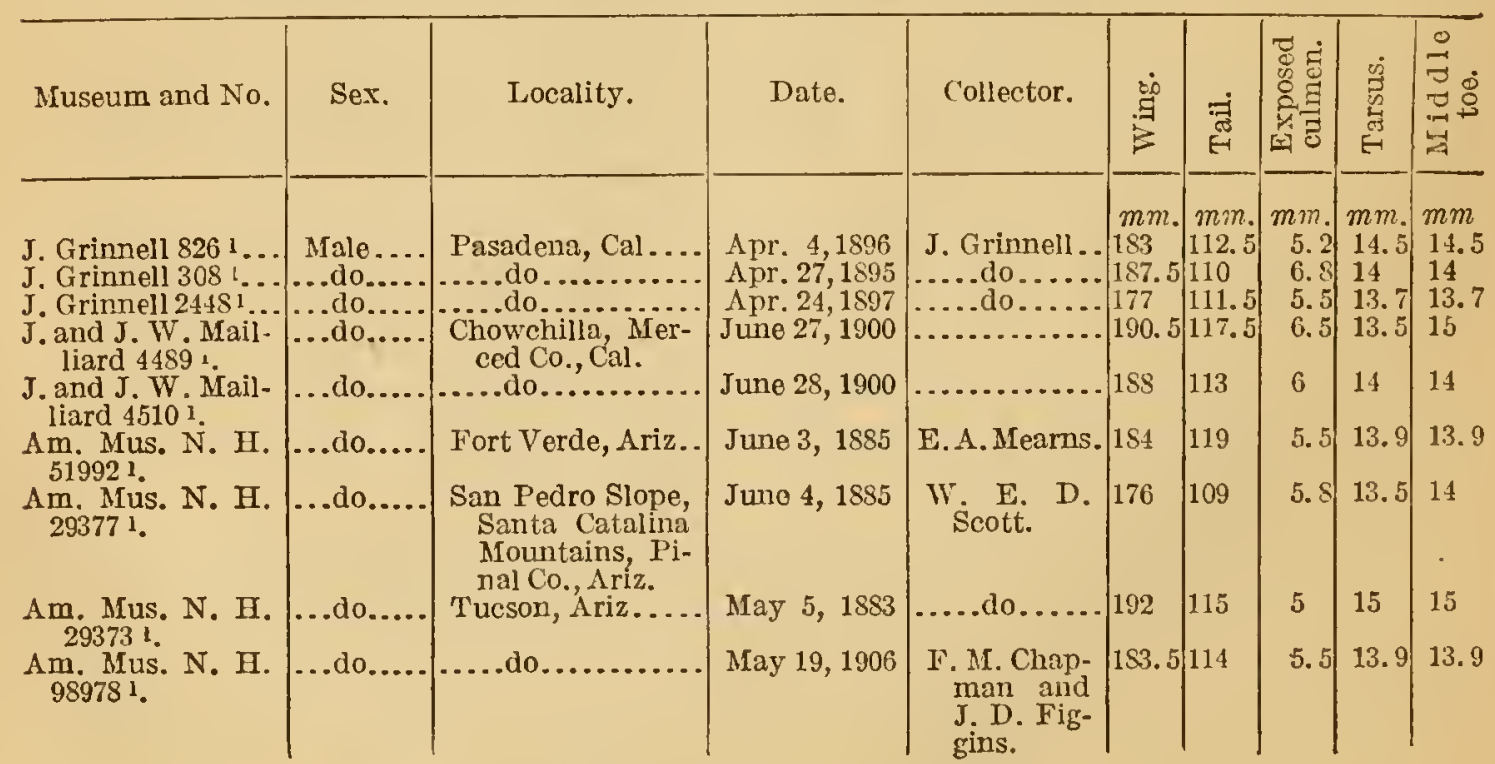

1 Used in measurement averages on p. 104. 
Measurements of specimens of Chordeiles aeutipennis texensis-Continued.

\begin{tabular}{|c|c|c|c|c|c|c|c|c|c|}
\hline Museum and No. & Sex. & Locality. & Date. & Collector. & $\stackrel{20}{\Xi}$ & Е & 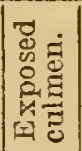 & 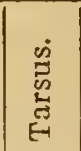 & 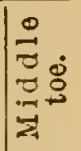 \\
\hline I. ( & & Tucso & & & $\prod_{186}^{m m}$. & $\left|\begin{array}{c}m m \\
111.5\end{array}\right|$ & $\begin{array}{r}m m . \\
5.5\end{array}$ & $\begin{array}{l}m m . \\
14.5\end{array}$ & $\begin{array}{l}m m .7 \\
14.7\end{array}$ \\
\hline 6311 & & Hidalgo, T & May 7,1889 & J.A. Singley & 183 & 108 & $\begin{array}{l}0.0 \\
5.5\end{array}$ & 14 & 14 \\
\hline$\underset{816051}{\operatorname{Am} .}$ Mus. N. H. & $\ldots d$ & $\ldots . . d \mathrm{dc}$ & May 23,1889 & 为 & 178 & 109 & 6.8 & 13 & 13 \\
\hline Am. Mus. N. H. & ...do. & .....do & May 27,1889 & & 183. & 111.5 & 6.2 & 14.5 & 14.5 \\
\hline U.S.N.M.140414 I.. & ...do & Rio Grande City, & June 1,1891 & W. Lloyd. & 173 & 104 & 6.2 & 14 & 14 \\
\hline$\underset{816141 .}{\operatorname{Am} . ~ M u s . ~ H . ~}$ & ... do & Lom & May 5, 1878 & G. B. Sen- & 186 & 109 & 6 & 14 & 15 \\
\hline $\operatorname{Am}_{43 \mathrm{~S} 52}$ Mus. N. H. & $\ldots$. & Texs & & J. P. Mc- & 165 & 97 & 6 & 13 & 14 \\
\hline ell 2449 k... & Fem & Pasade & 897 & J. Grinnell. . & 175 & 108 & 6 & 13.5 & 13. \\
\hline & & & & $\cdots$ & -175 & 110 & 6.1 & 13 & 148 \\
\hline & $\cdots d$ & & 897 & $\cdots$ & 170 & 106 & $\begin{array}{l}0 \\
6\end{array}$ & $\begin{array}{l}13 \\
14.2\end{array}$ & 15 \\
\hline $\begin{array}{l}\mathrm{J} \text { and J. W Mail- } \\
\text { liard } 4485 \text { i. }\end{array}$ & $\cdots d$ & $\begin{array}{l}\text { Chowchilla, irer- } \\
\text { ced Co.,Cal. }\end{array}$ & June & & 180 & 106 & 6.5 & 14.5 & 15.1 \\
\hline $\begin{array}{l}\text { Am. Mus. N. } \mathrm{H} . \\
29379 \mathrm{I}^{\mathrm{N}}\end{array}$ & ...do. & $\begin{array}{l}\text { San Pedro Slope, } \\
\text { Santa Catalina } \\
\text { Mountains, Pi- } \\
\text { nal Co., Ariz. }\end{array}$ & June 7,1885 & $W_{\text {Scott. }}$ E. & 178.5 & 104 & 6.2 & 13 & 14 \\
\hline$\underset{29374 \text { i. }}{\text { Am. }}$ & $\ldots$ do & Tuc & May 5, 1883 & do & 172 & 106 & 5.8 & 13.3 & \\
\hline $\begin{array}{l}\text { Am. Mus. N. H. } \\
293691 \text {. }\end{array}$ & $\ldots d$ & $\ldots . . d$ & June 2, 1884 & & 168. & 506 & 6 & 12.5 & 13.8 \\
\hline Am. Mus. N. H. & $\ldots d c$ & $\ldots . . d c$ & June 3,1884 &. & .173 & 109 & 6 & 15.2 & 15.8 \\
\hline$A_{27551} N_{\text {. }}$ S. Phila. & $\ldots$ & $\ldots . . . d$ & June 16,1891 & S. N. Rhoad & s 180 & 107.5 & 7 & 13.2 & 14 \\
\hline Am. Mus. N. H. & $\ldots d$ & Tex & & J. & 176. & 104 & 5.1 & 13.5 & 13.5 \\
\hline Field Mus. N. H. &.$d$ & Hidalgo, Tex & Apr. $18_{s} 1877$ & & 175 & 104 & 6.3 & 13.2 & 14.2 \\
\hline $\begin{array}{l}\text { Am. Mus. N. H. } \\
81603 ! \text {. }\end{array}$ & $\ldots d$ & $\begin{array}{l}\text { Rio Grande City, } \\
\text { Tex. }\end{array}$ & Jun & & 171 & 102 & 5.5 & 13 & 13 \\
\hline$\underset{81613 \text { I. }}{\operatorname{Am}_{\text {. M. }}}$ & ...do. & Lomita, Tex. . & Apr & G. B. Sen- & 180 & 105.5 & 6 & 13.5 & 14.3 \\
\hline & $d$ & ..d & May & & 177 & 106 & 5 & 13.3 & 14.5 \\
\hline
\end{tabular}

1 Used in measurement averages on p. 104.

2 Type of male.

3 Type of female.

CHORDEILES ACUTIPENNIS INFERIOR, new subspecies.

Chars. subsp.--Like Chordeiles acutipennis micromeris, but larger; light bars on tail broader; upper surface lighter, and averaging more brownish (less grayish) in general effect; similar to Chordeiles acutipennis texensis, but smaller.

Description.-Type, ádult male, No. 113100, U.S.N.M.; Triunfo, Lower California, Mexico, June 14, 1887; M. Abbott Frazar. Upper parts light brownish gray, with a more or less evident tinge of buff (particularly on the scapulars, which have some spots of ochraceous), and mottled, vermiculated, and irregularly barred with brownish black, the scapulars more or less solidly black medially, the cervix rather duller and more uniform; tail-feathers fuscous, more or less irregularly and rather broadly barred with buff, cream buff, and whitish, these bars on the upper side of the tail much mottled and broken by fuscous; a much broader pure white subterminal band; wing-quills fuscous, all but the outer primaries more or less spotted 
or barred on both vanes with tawny, ochraceous or buff, having also a broad white bar on four outer primaries mostly posterior to the tip of the eighth primary; outer primaries slightly edged or spotted on outer web with buff; wing-coverts and tertials mottled, spotted, and vermiculated with white, buff, and ochraceous buff, much like the back; edge of wing along the alula mostly buffy or creamy white; lores and supraloral region mixed white, buff, and dark brown; auriculars and postocular region blackish brown, much mixed with tawny, ochraceous, buff, and a little with white; chin buffy gray, with posteriorly heavy markings of dark brown; cheeks and sides of neck dark brown, much spotted and streaked with ochraceous, buff, and whitish; a large triangular patch on throat white; below this a band of dark brown much spotted with ochraceous buff; breast dark brown, finely mottled and vermiculated with pale brownish; rest of lower surface ochraceous buff, paler (buff) on lower breast, with conspicuous dark brown cross-bars, these narrower, farther apart, and somewhat broken on lower tail-coverts; lining of wing deep ochraceous buff, barred with dark brown.

Iris dark brown.

Measurements.-Female: Total length (in flesh), 203-223.5 (average, 210.1) mm.; ${ }^{1}$ extent of wing, $485-497.8(492.8) .{ }^{1}$

Male: ${ }^{2}$ Wing, 171.5-184.5 (average, 176.2) mm.; tail, 99-115 (107.1) ; exposed culmen, 4.9-6.5 (5.7); tarsus, 12.5-14.5 (13.5); middle toe, 13.2-15.1 (14).

Female: ${ }^{3}$ Wing, 165-177 (168.1)mm.; tail, 99-105 (102.3); exposed culmen, 5.0-6.0 (5.4); tarsus, 12.1-13.7 (13); middle toe, $12.5-14.8(13.7)$.

Type-locality.-Triunfo, Lower California, Mexico.

Geographical distribution.-Lower California. Breeds in the Upper Tropical, Lower Austral, and Upper Austral zones, south to San José del Cabo and Cape San Lucas; and north to La Grulla, Santa Cruz, and Valladares in the San Pedro Martir region of the northern part of the peninsula. Winters in extreme southern Lower California.

Remarks. - The juvenal plumage is similar to that of Chordeiles acutipennis acutipennis, but the lower parts average paler; and the upper surface is lighter, more uniform, more silvery, and less heavily mottled with blackish or dark brown. In the color of the upper parts it is strikingly like the first autumn stage of Chordeiles virginianus howelli, ${ }^{4}$ but is lighter, more silvery, and usually less mottlecl with dark brown or blackish.

\footnotetext{
1 Three specimens.

2 Ten specimels, from Lower Callfornia, Mexico.

3 Nine specimens, from Lower California.

see p. 60 .
} 
The difference between the gray and ochraceous phases of this subspecies are not nearly so great as in Chordeiles acutipennis cacutipennis and Chordeiles acutipennis micromeris; that is, while the gray phase is practically identical in color with the corresponding phase of Chordeites acutipennis micromeris, the ochraceous phase is not nearly so deeply ochraceous nor so different from the gray phase. The dark and light extremes in Chordeiles acutipennis inferior are, however, just as strongly marked as in the other races above mentioned.

Specimens examined.-The writer has seen 26 specimens of this new subspecies, from the localities that follow:

Lower California.-Cape San Lucas (Sept. 11, 14, and 21, 1859); San José del Cabo (Apr. 6, 1895; July 22, 1896; Ang. 5, 1896); Santa Anita (Jan. 14 and 16,1906); Trimnfo (June 11, 13, and 14, 1887); Valladares (May 21, 1889); Santa Cruz (May 23, 1889).

Measurements of specimens of Chordeiles acutipennis inferior.

\begin{tabular}{|c|c|c|c|c|c|c|c|c|c|}
\hline Museum and No. & Sex. & Locality. & Date. & Collector. & 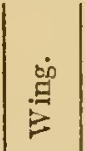 & ${ }_{\mathrm{E}}^{\mathrm{c}}$ & 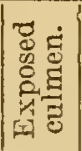 & 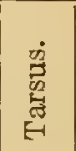 & 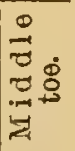 \\
\hline $\begin{array}{l}\text { Carnegie Mus. } \\
19857.1\end{array}$ & Male & $\begin{array}{l}\text { Santa Cruz,Lower } \\
\text { Cal. }\end{array}$ & Apr. 23, 1889 & $\begin{array}{l}\text { A. W. An- } \\
\text { thony. }\end{array}$ & $\mid \begin{array}{c}m m . \\
184.5\end{array}$ & \begin{tabular}{|c|}
$m m$ \\
115
\end{tabular} & $\underset{6}{m m}$ & $\begin{array}{l}m m \\
13.5\end{array}$ & $\begin{array}{l}m m \\
14\end{array}$ \\
\hline$\underset{19856.1}{\text { Carnegie Mus. }}$ & $\ldots d c$ & a & $\ldots . .8$ & & 176 & 112 & 6.2 & 12.5 & 13.2 \\
\hline $\begin{array}{c}\text { Carnegie Mus. } \\
19858.1\end{array}$ & ... do. & $\begin{array}{l}\text { Valladares, Lower } \\
\text { Cal. }\end{array}$ & May 21,1889 & ....do. & 172 & 105 & 6 & 13.5 & 13.5 \\
\hline us. N. H. & ... do. & $\begin{array}{l}\text { San José del Cabo, } \\
\text { Lower Cal. }\end{array}$ & July 22,1896 & Loye Miller. & 171. & 104 & 6.5 & 14.5 & 14.5 \\
\hline $5351 \ldots$ & $\ldots$ do & Cape San Lucas, & & & 174 & 104.5 & 5.2 & 13.5 & 13.5 \\
\hline Lus. N. H. & ... do. & $\begin{array}{l}\text { Triunfo, Lower } \\
\text { Cal. }\end{array}$ & June 13,1887 & $\begin{array}{l}\text { M. A. Fra- } \\
\text { zar. }\end{array}$ & 173 & 103 & 5.2 & 13.5 & 14 \\
\hline$\underset{29834.1}{\operatorname{Am} . \text { Mus. N. H. }}$ & do & din & June 1 & & 177.5 & 109.5 & 5 & 13.8 & 14.8 \\
\hline$\underset{29833.1}{\text { Am. Mus. N. H. }}$ & ... do. & .....do do & June 11,1887 & $d a$ & 172 & 99 & 4.9 & 12.5 & 13.5 \\
\hline $113100^{1}$. & . do do & .... do do & Jun & & 184 & 108 & 5.5 & 13.8 & 15.1 \\
\hline U.S. & . do & $\begin{array}{l}\text { Santa Anita, } \\
\text { Lower Cal. }\end{array}$ & Jan & $\begin{array}{l}\text { E. W. Nel- } \\
\text { son and } \\
\text { E.A.Gold- } \\
\text { man. }\end{array}$ & 177 & 111 & 6 & 13.5 & 13.5 \\
\hline A. N. S. Phila. & [ Female] & $\begin{array}{l}\text { Cape San Lucas, } \\
\text { Lower Cal. }\end{array}$ & & J. Xa & 165 & 99 & 5.2 & 13.7 & 14.8 \\
\hline Amer. Mus. N. II. & Female & & Sept.1 & & 165 & 102.5 & 6 & 12.1 & 13.1 \\
\hline $\begin{array}{l}\text { 1.C.Z. } 17608^{1} \ldots \\
\text { A.C.Z. } 43536^{1} \ldots\end{array}$ & do & $d$ & & $d 0$ & 171 & 105 & 5 & 13.2 & 14 \\
\hline & & $\cdots$ & & s de & 165 & 99 & 6 & 12.8 & 13.8 \\
\hline d O. Bangs & ... do & $\begin{array}{c}\text { Triunfo, Lower } \\
\text { Cal. }\end{array}$ & June 13,1887 & $\begin{array}{l}\text { M. A. Fra- } \\
\text { zar. }\end{array}$ & 167 & 103.5 & 5.3 & 12.5 & 12.5 \\
\hline & ... do & $\begin{array}{l}\text { San José del Cabo, } \\
\text { Lower Cal. }\end{array}$ & Apr. 6,1895 & J. E. McLel- & 165 & 100.5 & 5.5 & 13 & 13.5 \\
\hline U.S.N.M. 1977831. & ...do. & $\begin{array}{l}\text { Santa A n ita, } \\
\text { Lower Cal. }\end{array}$ & Jan. 14,1906 & $\begin{array}{l}\text { E. W. Nel- } \\
\text { son and } \\
\text { E.A.Gold- } \\
\text { man. } \\
\text {.....do....... }\end{array}$ & 169 & 104.5 & 5 & 13.5 & 13.5 \\
\hline
\end{tabular}

1 Used in measurement averages on p. 110.

2 Type. 


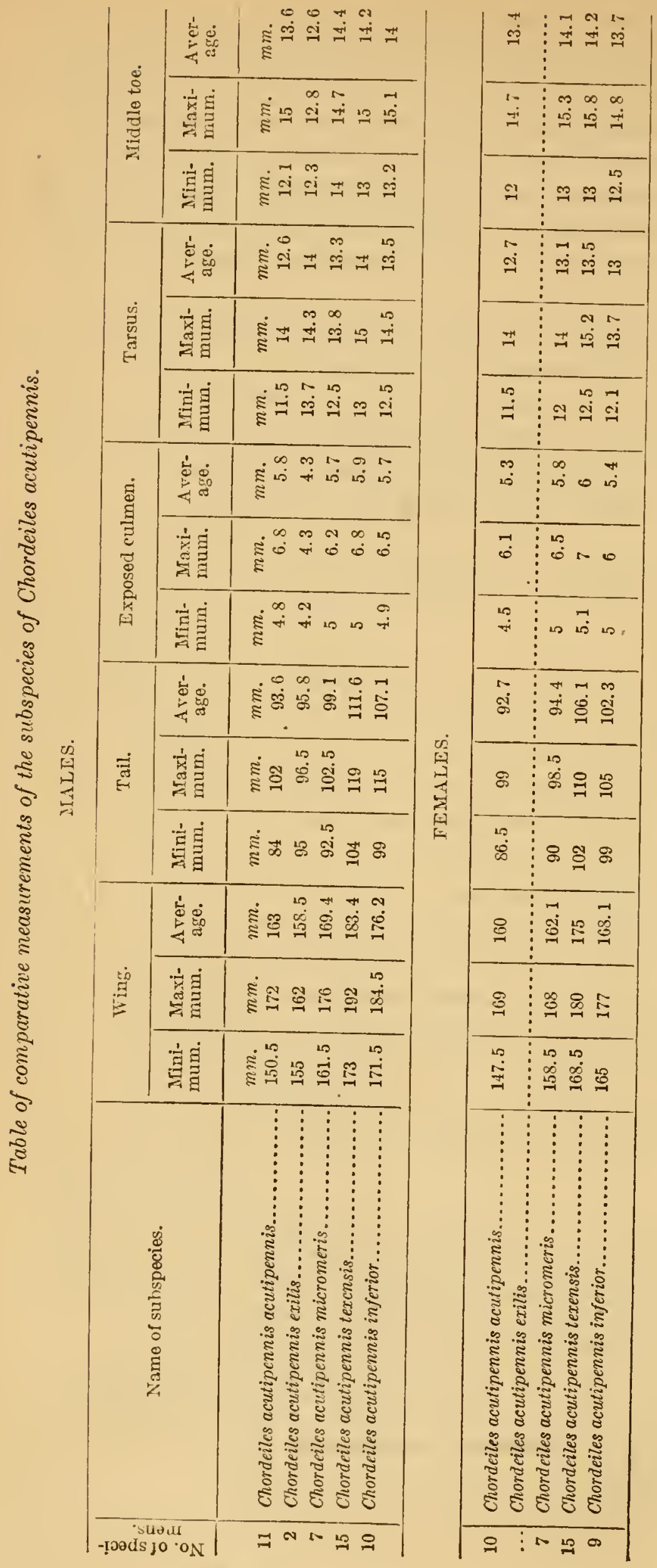




\section{CHORDEILES RUPESTRIS (Spix).}

Oaprimulgus rupestris SpIx, Avium Spec. Nov. Bras., vol. 2, 1825, p. 2, pl. 2 ("insulis petrosis fl. Nigri")."

Chars. sp. (adult male). - First (outermost) primary longer than second; shortest secondary usually reaching or exceeding the tips of the primary coverts; distance from bend of folded wing to end of shortest secondary nearly always greater than from latter point to end of fourth primary (counting from the outermost) ; tips of tailfeathers rounded; upper surface varied with dark brown, whitish, buff, and ochraceous; tail chiefly white, the two middle rectrices, most of the next pair, the outer webs of outermost pair, and broad tips to all, brown; middle portion of inner primaries and basal portion of nearly all the secondaries pure white; the remaining portions of these quills, together with the three outer primaries and the primary coverts, plain fuscous, unspotted; axillars and middle portion of under wing-coverts pure white; lower surface pure white; the jugulum and upper breast spotted and the former more or less clouded with pale brownish gray or grayish brown.

Adult female.-Similar to the adult male, but smaller; upper parts more ochraceous or buffy, less closely vermiculated, and rather lighter; fourth primary (counting from the outermost) with usually at least a small spot of white on middle part of inner web; tail with the broad brown tips much mottled with lighter, instead of usually plain brown or nearly so; those rectrices that are mostly white having more dark brown at base (commonly none in the male), and the white area of inner web with one or two spots or bars of dark brown; outer web of outermost rectrix all brown without a subterminal white area, and this brown much, instead of little or not all, mottled with lighter.

Remarks.-The present species seems to be a comparatively rare one, and the small number of specimens now available precludes any satisfactory elucidation of the various plumages, molt, variation, and the many other problems connected with every species. Individual variation seems to concern chiefly size; the shade of the markings on the breast; the amount of white on the greater wing coverts; and the coarseness of the markings on the upper surface.

Geographical distribution.-The geographical distribution of Chordeites rupestris is entirely in northern and central South America, and extends from northern Brazil to Colombia, Peru, and Bolivia. To the single race previously recognized the present investigation adds two, one from central Colombia, the other from eastern Peru. Both of these, however, are known from only a limited area, and by far the greater part of the total range of the species is occupied by the typical subspecies, Chordeiles rupestris rupestris. 
Habits.-So far as known, this species is nonmigratory, and in general habits similar to the other members of the genus. It is said to breed often in colonies in September on the sand banks and beaches of the Amazon River and its tributaries; and its eggs are described as creamy or buffy white with numerous grayish markings.

Phylogeny.-The Brazilian subspecies Chordeiles rupestris rupestris, seems, from its wide geographical distribution and central location, to be the oldest form. Both Chordeiles rupestris xyostictus and Chordeiles rupestris zaleucus are thus doubtless more recent offshoots, merely geographic races modified into such by isolation or environment.

History.-This species was first described by Spix, in his famous work on the birds of Brazil, ${ }^{1}$ from specimens obtained on the Rio Negro. Its literature is limited, and it appears to have no synonyms. All the references to its literature, so far as possible, will be given under the headings of the subspecies, as perhaps of interest.

\section{CHORDEILES RUPESTRIS RUPESTRIS (Spix).}

Caprimulgus rupestris SPIX, Avium Spec. Nov. Bras., vol. 2, 1S25, p. 2, pl. 2 ("insulis petrosis fl. Nigri").

C[hordeiles]. rupestris GraY, Genera Birds, rol. 1, January, 1847, p. 49.

[Chordeiles] rupestris Bonaparte, Consp. Gen. Avium, vol. 1, 1550, p. 63.GraY, Mand-List Gell. and Spec. Birds, rol. 1, 1869, p. 61 (part, Rio Negro, Brazil).-Giebel, Thesaur. Ornith., vol. 1, 1872, p. 669 (part).Sclater and Salvin, Nomencl. Avium Neotrop., 1873, p. 96 (Amazonia).-SirArpe, Hand-List Gen. and Spec. Birds, vol. 2, 1900, p. 80 (part, Amazonia).

Chordeiles rupestris Burmetster, Syst. Uebers. Thiere Bras., vol. 2, 1856, p. 393 (Rio Negro, Brazil).-Sclater, Cat. Amer. Birds, 1862, p. 279 (upper Amazon River) ; Proc. Zool. Soc. Lond., 1S66, I) 135 (part, rocky islands of Rio Negro, Brazil).-Sclater and Salvin, Proc. Zool. Soc. Lond., 1867, p. 583 (upper Rio Negro, Brazil).-PelzelN, Oruith. Bras., 1S68, p. 14 (Rio Guaporé; Rio Mamoré; Manaqueri, Rio Solimoëns, Brazil).-Sclater and Salvin, Proc. Zool. Snc. Lond., 1879, p. 626 (Prov. Moxos, Bolivia).-Hartert, Cat. Bir(is Brit. Mus., vol. 16, 1892, p. 617 (crit.; part; Para and Pernambuco, Brazil); Tierreich, Lief. 1, 1897, p. 20 (crit.).-NeHrkorN, Kat. Eiersammlung, 1899, p. 158 (eggs, Amazon River).-Ihering, Rev. Mus. Paulista, rol. 4, 1900, p. 257 (descr. eggs) ; vol. 6, 1905, p. 443 (Rio Juruá, Brazil).-Goeldr, Album Aves Amazonicas, fasc. 3,1906 , pl. 46, fig. 8 (Rio Purus, Brazil).Inering and Inering, Cat. Fauna Bras., rol. 1, Ares, 1907, p. 132 (part; Matto Grosso; Rio Amazonas; Para; Rio Negro; Peruambuco; Rio Juruá; and Amazonas, Brazil; Bolivia).-Snetrlage, Journ. $f$. Ornith., January, 1908, p. 18 (Cachoeira and Bom Lugar on Rio Purás, Brazil).-Hellmayr, Novit. Zool., vol. 17, December, 1910, p. 378 (part, Jamarysinho, on Rio Madeira, Brazil). 
Chars. subsp.-Size small; colors relatively dark; blackish and dark brown markings of upper surface rather coarse; breast sparsely spotted; female with only dark brown spots on inner webs of outer rectrices; and with no large white patch on inner vane of fourth primary (counting from the outermost).

Description.-Adult [male], No. 21995, Academy of Natural Sciences of Philadelphia; Rio Negro, Brazil; M. Wülf. Upper surface broccoli brown, spotted, streaked, barred, and vermiculated with grayish sepia, most heavily on pileum, scapulars, and upper tailcoverts, and in places tinged with buff, the outer margins of scapulars almost entirely buff; tail white, the two middle feathers hair brown, irregularly barred and finely mottled with dark brown; the outer vane of outermost rectrix (excepting a very narrow white edge and a broad subterminal white space) and broad tips on all the rectrices, save the middie pair, dark brown, between clove brown and hair brown; primaries of the same brown, the four outermost unmarked, the next four with their bases (excepting the outer vanes) and all but the broad brown tips, pure white; rest of primaries and all of secondaries narrowly tipped with whitish and otherwise all white save for broad, dark brown ends; anterior rows of superior wing-coverts dark brown like the wing-quills, spotted and imperfectly barred with buff and whitish; remainder of wingcoverts deep broccoli brown, spotted, barred, mottled, and tipped with white, cream color, pale clay color, and buff; tertials broccoli brown, terminally dull buff, with shaft streaks and broken, irregular bars and vermiculations of deep broccoli brown; sides of head and neck broccoli brown, with fine markings of dark brown, the auriculars buffy and nearly plain; an indistinct buffy white superciliary stripe; entire lower surface creamy white, the jugulum with a wide, grayish buff, partly whitish band, obscurely barred and spotted with broccoli brown; lining of wing white, excepting the outel coverts, which are dark brown like the wing-quills, and the posterior ones, which are grayish drab; edge of wing along the alula mostly white.

Measurements.-Male: ${ }^{1}$ Wing, $167-170$ (average 168.5) mm.; tail, 94 ; exposed culmen, 6.5 ; tarsus, $13-13.5$ (13.3) ; middle toe, 13-13.2 (13.1).

Female: ${ }^{2}$ Wing, $159.5 \mathrm{~mm}$; tail, 90 ; exposed culmen, 5.0 ; tarsus, 12 ; middle toe, 13.

Type-locality.-Rocky islands of the Rio Negro, northern Brazil.

Geographical distribution.-Permanently resident in northern and central Brazil and northeastern Bolivia: north to Para and the upper 
Rio Negro, Brazil; west to the upper Rio Negro; the Rio Juruá; Cachoeira and Bom Lugar on the Rio Purús; Jamarysinho on the Rio Madeira; the Rio Guaporé, Brazil; the Moxos region, northeastern Bolivia; and Matto Grosso, Brazil; south to Matto Grosso and Pernambuco, Brazil ; and east to Pernambuco and Para, Brazil.

Remarks.-Individual and sexual variation have been already discussed in the account of the species above. This race, so far as reported, occupies a much larger geographical area than the others, and its known range will probably greatly increase as the result of future explorations. All of the specimens examined will be found listed in the table of measurements appended.

Measurements of specimens of Chordeiles rupestris rupestris.

\begin{tabular}{|c|c|c|c|c|c|c|c|c|c|}
\hline Museum and No. & Sex. & Locality. & Date. & Collector. & $\sum^{\infty}$ & $\begin{array}{l}\text { न्ं } \\
\text { Ë }\end{array}$ & 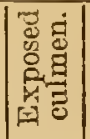 & 泀 & 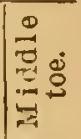 \\
\hline $\begin{array}{l}\text { U.S.N.M.1483681 } \\
\text { A.N.S.Phila.21995. } \\
\text { A.N.S.Phila.21996. }\end{array}$ & $\begin{array}{l}\text { [Male.].. } \\
\text { [Male.].] } \\
\text { [Female.] }\end{array}$ & $\begin{array}{l}\text { Brazil............ } \\
\text { Rio Negro, Brazil } \\
\text {..... do............. }\end{array}$ & & $\begin{array}{l}\text { ir. wülf... } \\
\text {.... do.... }\end{array}$ & $\begin{array}{l}m m \\
170 \\
167 \\
159.5\end{array}$ & $\begin{array}{r}m m . \\
94 \\
94 \\
90\end{array}$ & $\begin{array}{c}m m \\
6.5 \\
6.5 \\
5\end{array}$ & $\begin{array}{l}m m . \\
13 \\
13.5 \\
12\end{array}$ & $\begin{array}{l}m m . \\
13 \\
13.2 \\
13\end{array}$ \\
\hline
\end{tabular}

1 Used in measurement averages on p. 115.

CHORDEILES RUPESTRIS XYOSTICTUS, new subspecies.

Chars. subsp.-Similar to Chordeites rupestris mupestris, but somewhat larger; upper surface, including the wing-coverts, much paler, more buffy (less grayish), the dark markings much smaller; and breast more heavily spotted.

Description.-Type, adult male, No. 16599, U:S.N.M.; Bogota, Colombia; W. Evans. Upper surface pale drab, shading to ochraceous buff on the outer part of the scapulars, spotted, vermiculated, obscurely streaked, and narrowly and brokenly barred with broccoli brown, the barring most evident on upper tail-coverts and scapulars, the scapulars also a little barred and narrowly streaked with dark brown, between clove brown and hair brown, and the pileum conspicnously streaked with the same; tail cream white, the two central feathers basally rather light broccoli brown, distally hair brown, irregularly barred and finely mottled with a dark grayish brown, between clove and hair brown; the outer vane of outermost rectrix (excepting a very narrow light brownish edge and a broad subterminal white space) and broad tips on all the rectrices save the middle pair, of the same dark brown as the bar's on the middle tail-feathers; primaries of the same brown, but somewhat darker, the four outermost unmarked, the next four with their bases (excepting the outer vanes) and all but the broad brown tips, cream white; rest of primaries and all of secondaries narrowly tipped with 
whitish (the secondaries more so), and otherwise all white save for broad dark brown ends; the tips of the two inner secondaries somewhat mottled with pale drab; innermost secondary and the tertials light drab, mottled, vermiculated, and narrowly and irregularly barred with broccoli brown, basally also with whitish and buffy; anterior rows of upper wing-coverts dark brown like the wing-quills, much spotted, mottled, and imperfectly barred with buff and whitish; remainder of wing-coverts deep broccoli brown, spotted, barred, mottled, and tipped with white, cream color, pale clay color, and buff; sides of head and neck pale buffy gray, more buffy on auriculars, which are narrowly and inconspicuously streaked with brown, all the rest speckled, spotted, and a little streaked and barred with broccoli brown, the streaks darker brown; lores anteriorly sthitish; an ill-defined superciliary stripe due to the sparseness of the dark spotting; entire lower surface cream white, the jugulum with a wide band of drab gray, obscurely spotted and barred with drab and broccoli brown, the breast conspicuously spotted and imperfectly barred with broccoli brown; inferior wing-coverts cream white, the outer ones dark brown like the wing-quills, somewhat spotted and edged with buff, ochraceous, and whitish, the posterior and longest grayish drab; edge of wing along the alula mostly buffy white.

Measurements.-Male: ${ }^{1}$ Wing, $172.5 \mathrm{~mm}$.; tail, 100; exposed culmen, 7.0 ; tarsus, 13.1 ; middle toe, 13.1.

Female: ${ }^{2}$ Wing, $165.5 \mathrm{~mm}$.; tail, $92.5 \mathrm{~mm}$.; exposed culmen, 7.0; tarsus, 13.1 ; middle toe, 13.9 .

Type-locality.-Bogota, Colombia.

Geographical distribution.-Central Colombia. Probably a permanent resident.

Remaris.--This species (Chordeiles rupestris) has hitherto been unrecorded from Colombia, and it must be rare in that country. The two specimens listed in the subjoined table of measurements were collected at Bogota, Colombia, by Mr. W. Evans, and have been in the United States National Museum since 1860. They seem to represent a very well characterized geographical race.

Measurements of specimens of Chordeiles rupestris xyostictus.

\begin{tabular}{|c|c|c|c|c|c|c|c|c|c|}
\hline Museum and No. & Sex. & Locality. & Date. & Collector. & $\stackrel{\dot{0}}{9}$ & ت્ّ & 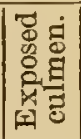 & 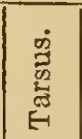 & 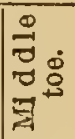 \\
\hline $\begin{array}{l}\text { U.S.N.M. } 16599^{3} \ldots \\
\text { U.S.N.M. } 16600^{3} \text {... }\end{array}$ & $\begin{array}{l}\text { [Male] }{ }^{4} \\
\text { [Female] }\end{array}$ & $\begin{array}{l}\text { Bogota, Colombia } \\
\ldots . . \text { do.............. }\end{array}$ & & $\begin{array}{l}\text { W.Evans... } \\
\text {.....do...... }\end{array}$ & $\begin{array}{l}m m . \\
172.5 \\
165.5\end{array}$ & $\begin{array}{c}m m \\
100 \\
92.5\end{array}$ & $\begin{array}{r}m m \\
7 \\
7\end{array}$ & $\begin{array}{l}m m . \\
13.1 \\
13.1\end{array}$ & $\begin{array}{c}m m \\
13.1 \\
13.9\end{array}$ \\
\hline
\end{tabular}

1 One specimen, from Colombia.

2 One specimen, from Colombia.

3 Used in measurement averages on p. 117.

1 Type. 
CHORDEILES RUPESTRIS ZALEUCUS, new subspecies.

Chordciles rupostris Sclater, Proc. Zool. Soc. Loud., 1S66, p. 133 (part, lower Ucayali River, eastern Peru).-Sclater and Salvin, Proc. Zool. Soc. Lond., 1866, p. 193 (lower Ucayali River, eastern Peru) ; 1S7s, p. 290 (lower Ucayali River and entire Huallaga River [breeding], eastern Peru).—Taczanowski, Ornith. Pérou, rol. 1, 1884. p. 214 ( upper Ucayali River, Huallaga River, and Pebas, Peru).--Hartert, Cat. Birls Brit. Mus., vol. 16, 1892, p. 617 (part, Ucayali River, Iquitos, and Pebas, Peru).-Oates and Reid, Cat. Coll. Birds' Eggs Brit. Mus., vol. 3, 1903, p. 58 (Ucayali River, Peru).-Ihering and Ihering, Cat. Fauna Bras., rol. 1, Ares, 1907, p. 132 (part, eastern Peru).-Hellanarr, Novit. Zool., December, 1910, p. 378 (part) (Peru).

[Chordeiles] rupestris GraY, Hand-List Gen. and Spec. Birds, vol. 1, 1869, p. 61 (part, lower Ucayali River, Peru).-Shanpe, Hand-List Gen. and Spec. Birds, vol. 2, 1900, p. $S 0$ (part, Bolivia, Peru).

Chars. subsp.-Resembling Chordeiles rupestris rupestris, but female more grayish above, particularly on wing-coverts; with a large white patch $47 \mathrm{~mm}$. long on middle portion of inner web of fourth primary (counting from the outermost), this patch reaching to the shaft, which is white itself at this point; inner web of outermost rectrix with two broad dark brown bands (instead of spots) besides the terminal and the basal bands; spots on breast larger and more numerous.

Description.-Type, adult [female], ${ }^{1}$ No. 55318, U.S.N.M., Pebas, Peru ; Prof. James Orton ; original number, 275. Upper surface light drab (the scapulars exteriorly largely buff or ochraceous buff), finely and confusedly spotted, streaked, barred, and vermiculated with dull white, darker drab, broccoli brown, grayish sepia, and grayish clove brown, the darkest brown markings mostly confined to pileum, scapulars, and upper tail-coverts, the pileum and middle of back more strealsed, the posterior upper parts more barred; tail largely cream white, but basal portion of the feathers, and two (on some of the feathers only one) broad but somewhat broken and incomplete bars, of a dark brown, between clove brown and hair brown; ends of rectrices, except middle pair, with a wide band of the same dark brown, though much mottled above and below with lighter brown; outer webs of outermost and all of the next to the middle pairs of rectrices partly light, partly darker, broccoli brown, mottled and more or less irregularly barred with the dark brown of their tips; middle pair of feathers basally broccoli brown, distally rather grayish hair brown, finely mottled and vermiculated, particularly on terminal half, with the dark brown of the rest of the tail, and crossed by six rather narrow, and distally much broken bars of the same dark brown; primaries of the same dark brown as the tips of the tail-feathers, but somewhat more grayish, the three outer quills unmarked, the fourth with 
a large white spot on the middle portion of the inner vane, this spot $47 \mathrm{~mm}$. long on the inner edge of the vane, $29 \mathrm{~mm}$. in length along the shaft, which for this space is also white; remaining primaries mostly white, with some dark brown at the bases, principally on onter webs, and with broad dark brown ends which have narrow paler or whitish tips; secondaries, except the innermost three, chiefly white, with basal portion of inner webs and broad ends dark brown, the latter somewhat mottled with lighter brown and narrowly tipped with brownish white; the next secondary white, but with an increased amount of dark brown on the base and on outer vane; the end also broadly dark brown, mottled with lighter and tipped with whitish, but with an additional broad bar of dark brown; next secondary (the second from innermost) nearly all dark brown, with a large spot of cream white on the middle portion of inner web, several spots of pale brownish buff, and a narrow tip of brownish white; innermost secondary and the tertials light broccoli brown, terminally inclining to buff, vermiculated, and irregularly and narrowly barred with dark broccoli brown; anterior rows of lesser wing-coverts dark brown like the wing-quills, spotted, barred, and tipped with buff, pale brown, and brownish white; remaining upper wing-coverts also dark brown, but so heavily spotted, vermiculated, and irregularly barred with pale broccoli brown, buff, ochraceous buff, cream buff, pale clay color, and brownish white as to appear very much like the upper parts, though decidedly lighter; sides of head and neck for the most part finely mottled with dull white, cream buff, grayish hair brown, and broccoli brown, the ear-coverts nearly plain light clay color, with a few narrow streaks of dark brown, the postauricular region ochraceous buff, with conspicuous dark brown streaks; chin buffy white, with a few obscure brownish spots; broad crescent on throat, white; jugulum pale grayish buff, with broad streaks of dull white, numerous small spots, and narrow, more or less imperfect, bars of broccoli brown; remainder of lower parts cream white, the breast with broken bars and spots of broccoli brown; axillars cream white; inner lower wing-coverts also cream white, unmarked, the outer ones dark brown like the wing-quills, conspicuously spotted and brokenly barred with cream white, cream color, cream buff, and ochraceous buff; posterior lower wing-coverts plain light brownish gray.

Measurements.-Female (type) : Wing, $162 \mathrm{~mm}$.; tail, 89 ; exposed culmen, 7.5 ; tarsus, 13.5 ; middle toe, 14.

Taczanowski ${ }^{1}$ gives the following dimensions of a male: Wing, $162 \mathrm{~mm}$.; tail, 87 ; middle rectrix, 76 ; bill, 23 ; $^{2}$ bill from nostril, 5.0 ; tarsus, 13 . Of a female: Wing, 153 ; tail, 89 ; middle rectrix, 75 ; bill, $24 ;^{2}$ bill from nostril, 5.0 ; tarsus, 13 . 


\section{Type-locality.-Pebas, Peru.}

Geographical distribution.-Resident in eastern and central Peru: north to Pebas and Yquitos, northern Peru; west to the Huallaga River, central Peru; south to the upper Ucayali River, southern Peru; and east to the latter locality and to Pebas in northeastern Peru.

Remarks.-Although the writer has seen but a single specimen of this race, it is apparently easily recognizable by the character of the white markings on the primaries alone, though it can be distinguished also by its other characters. It differs from Chordeiles rupestris xyostictus in having somewhat shorter wings and tail; in the female, by reason of its rather darker and decidedly less buffy upper surface; rather larger dark brown markings on head, back, scapulars, and wing-coverts; a large white patch on the fourth primary; dark brown bars, instead of only spots, on the inner vane of outermost tailfeather; and less buffy jugulum. C. E. Hellmayr mentions ${ }^{1}$ the darker upper surface of Peruvian specimens of Chordeiles mupestris, but gives no other differences.

The probable range of this subspecies is as above outlined, but since we have examined actual specimens from only Pebas, Peru, its geographical limits may be subject to change when adequate material is available. 


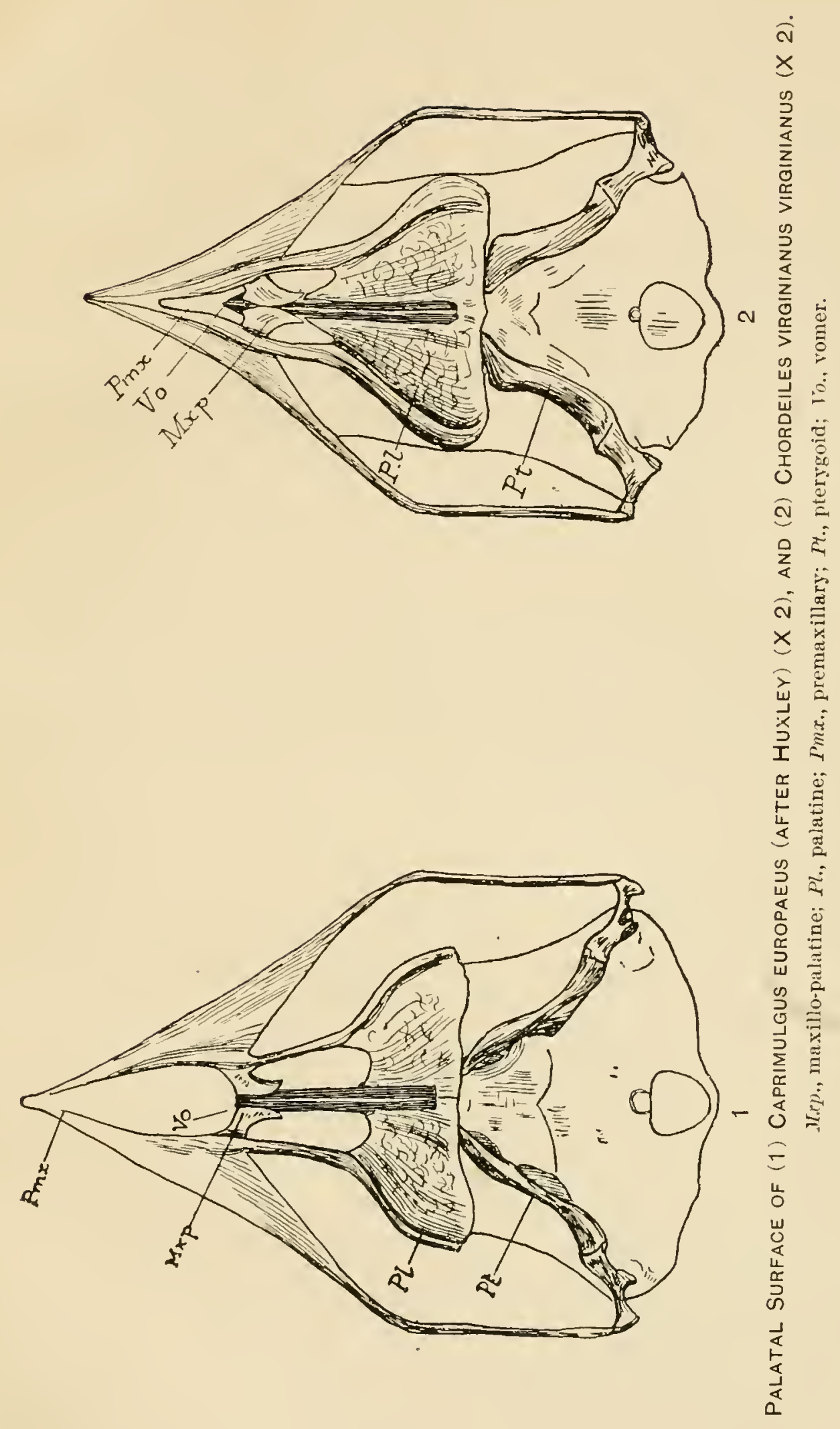





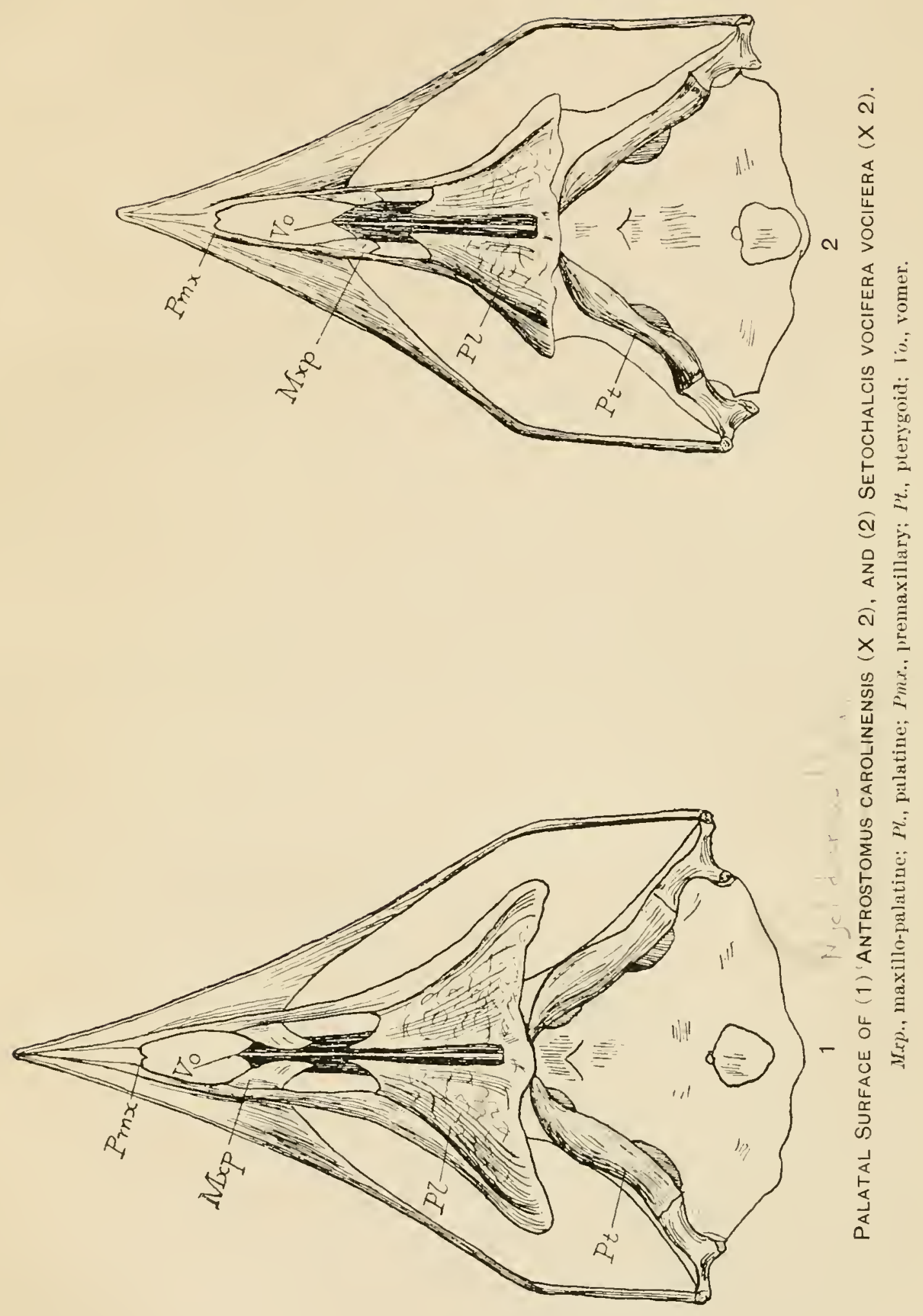






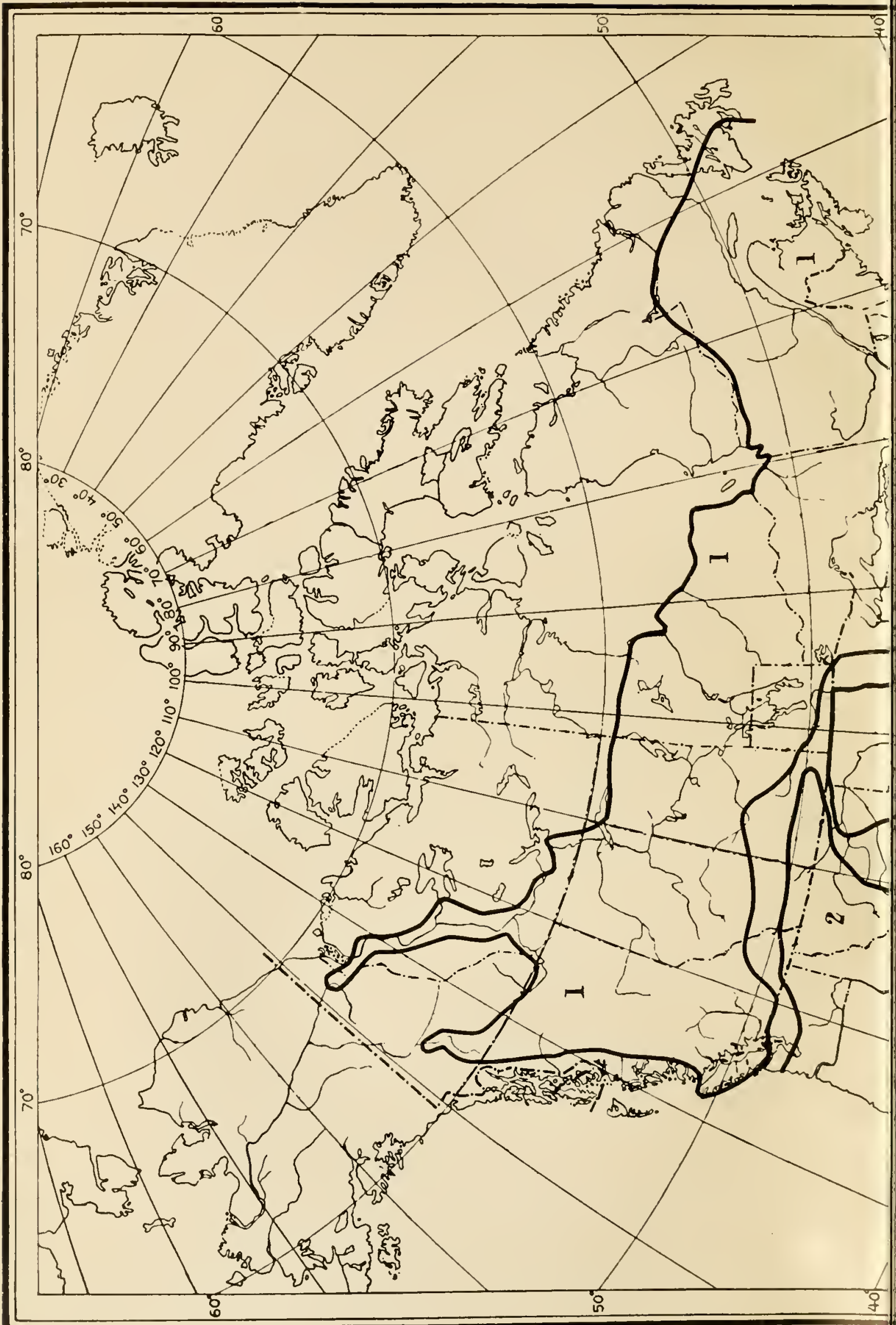




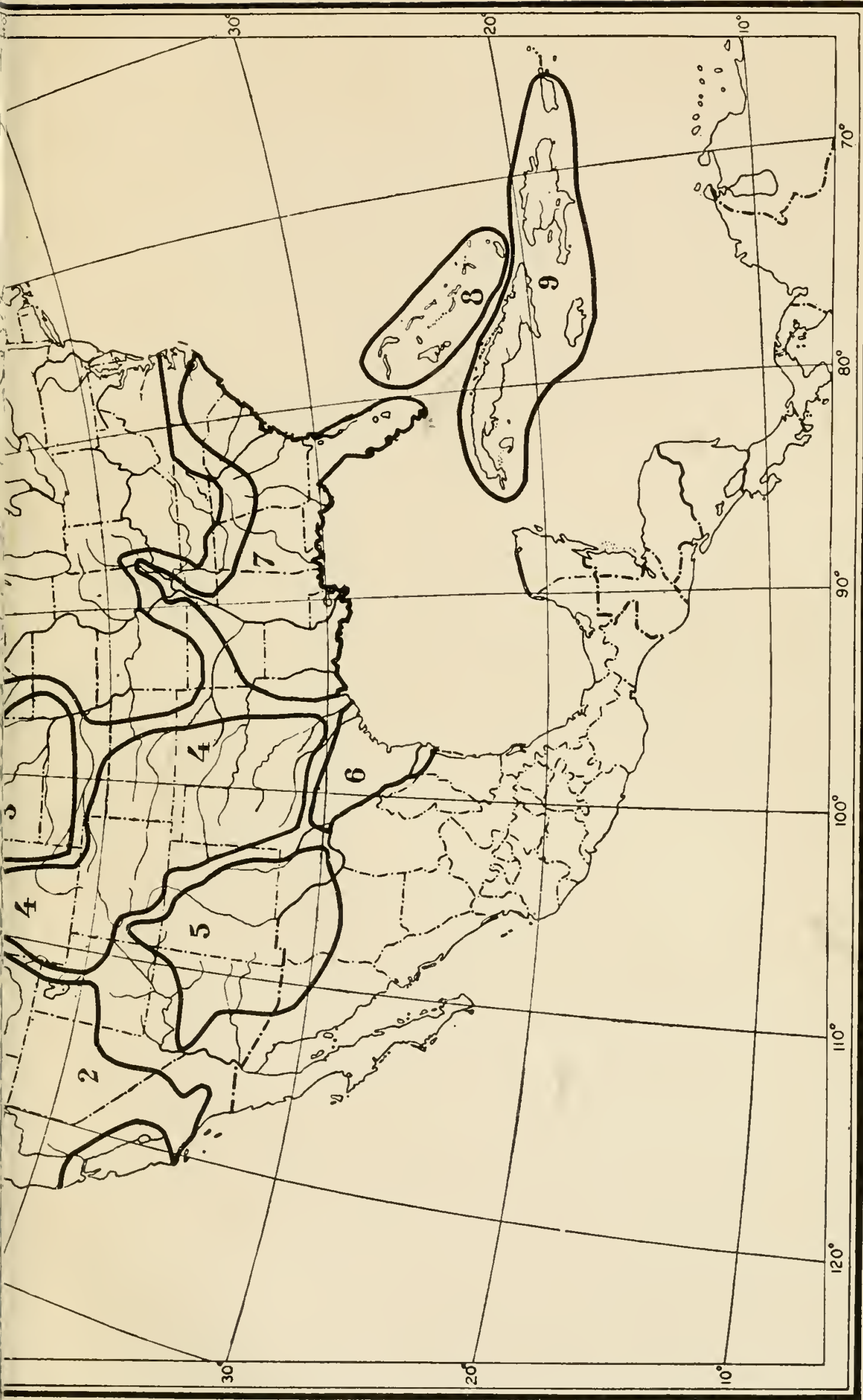

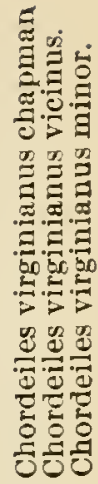






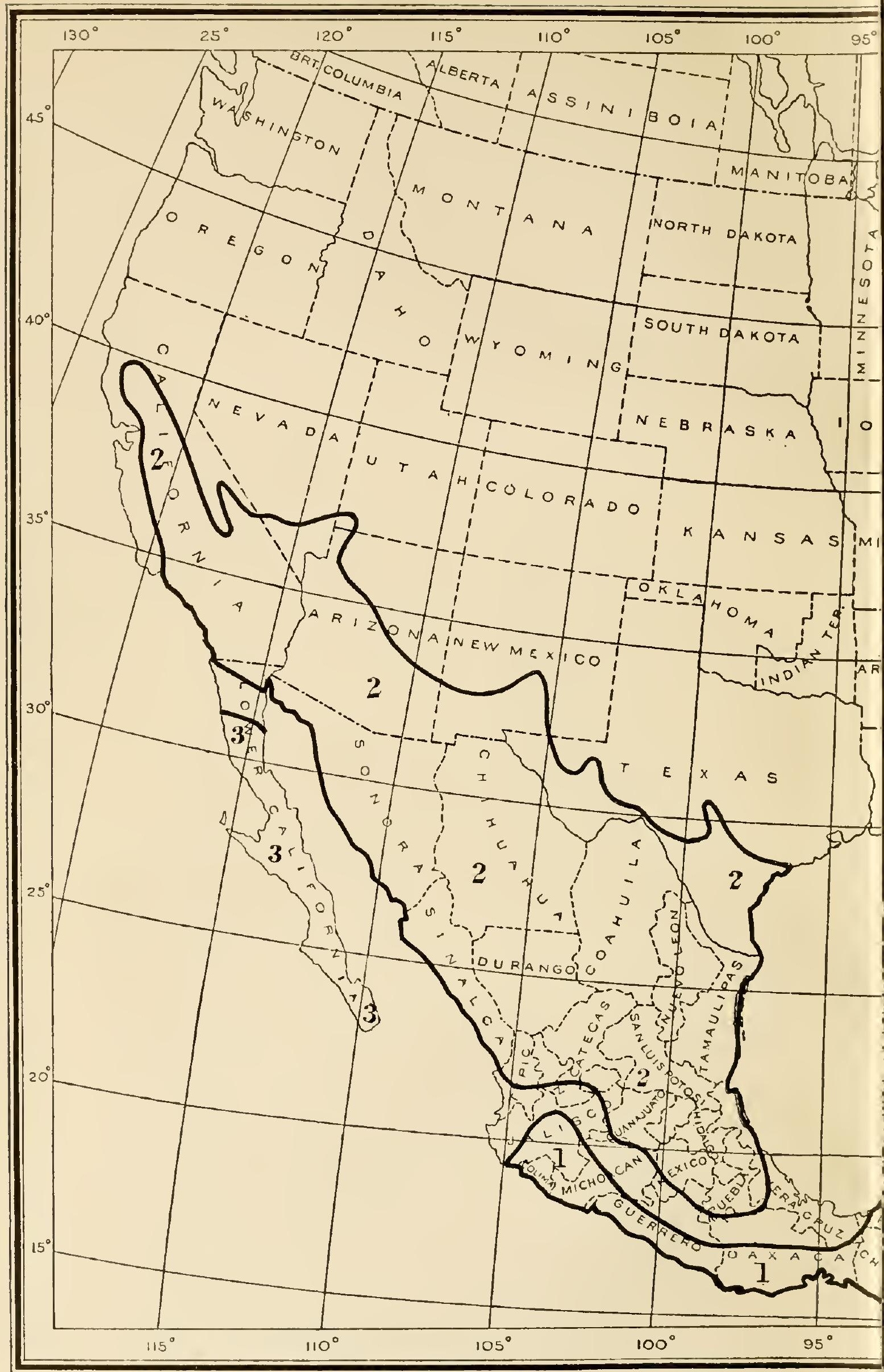

Breeding Ranges of the Central american and i 



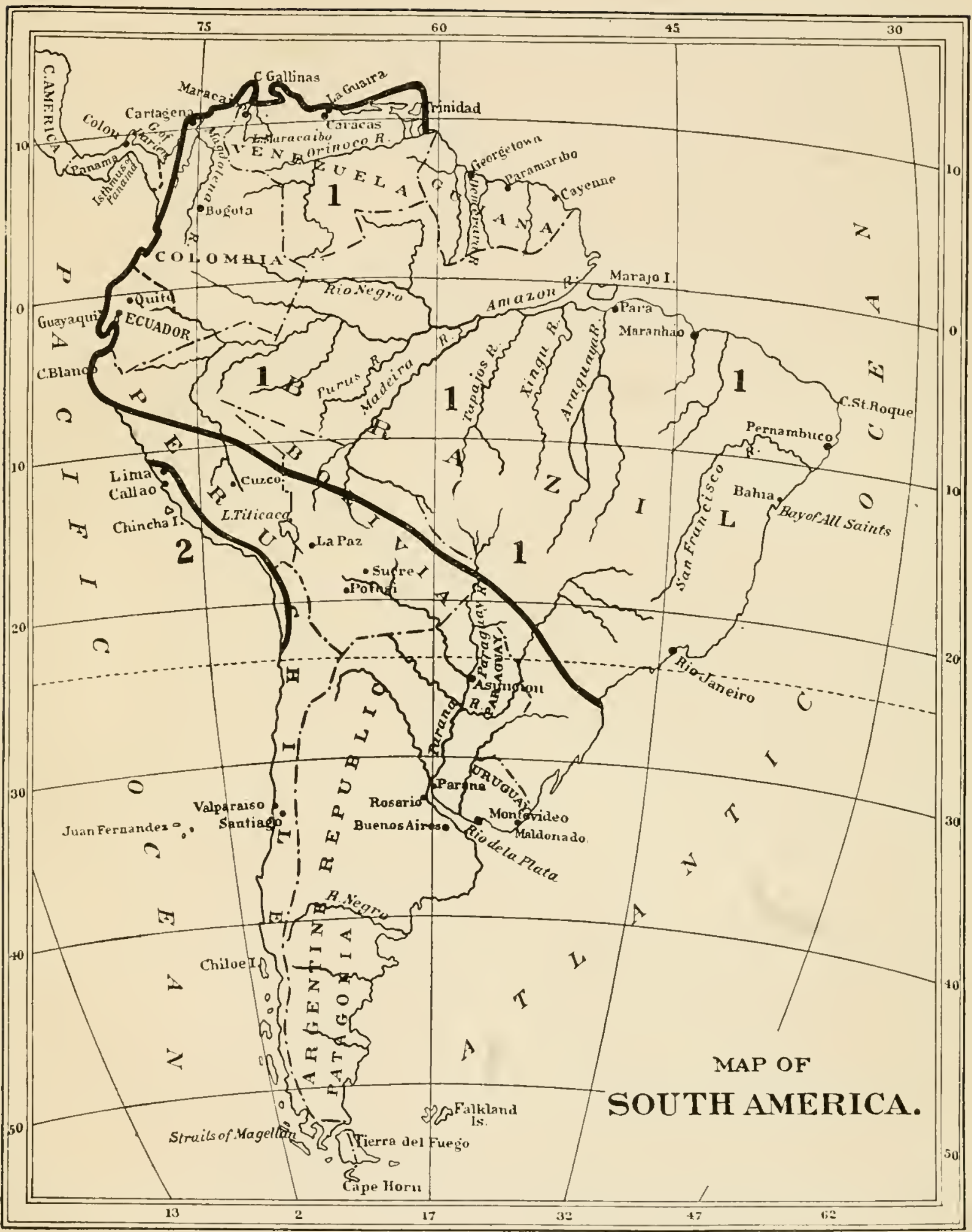

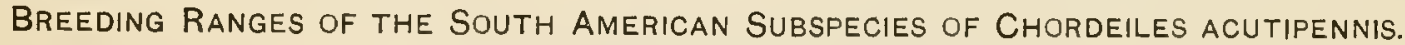

1. Chorkeiles acutipenuis acutipenuis.

2. Chordeiles acutipennis exilis. 



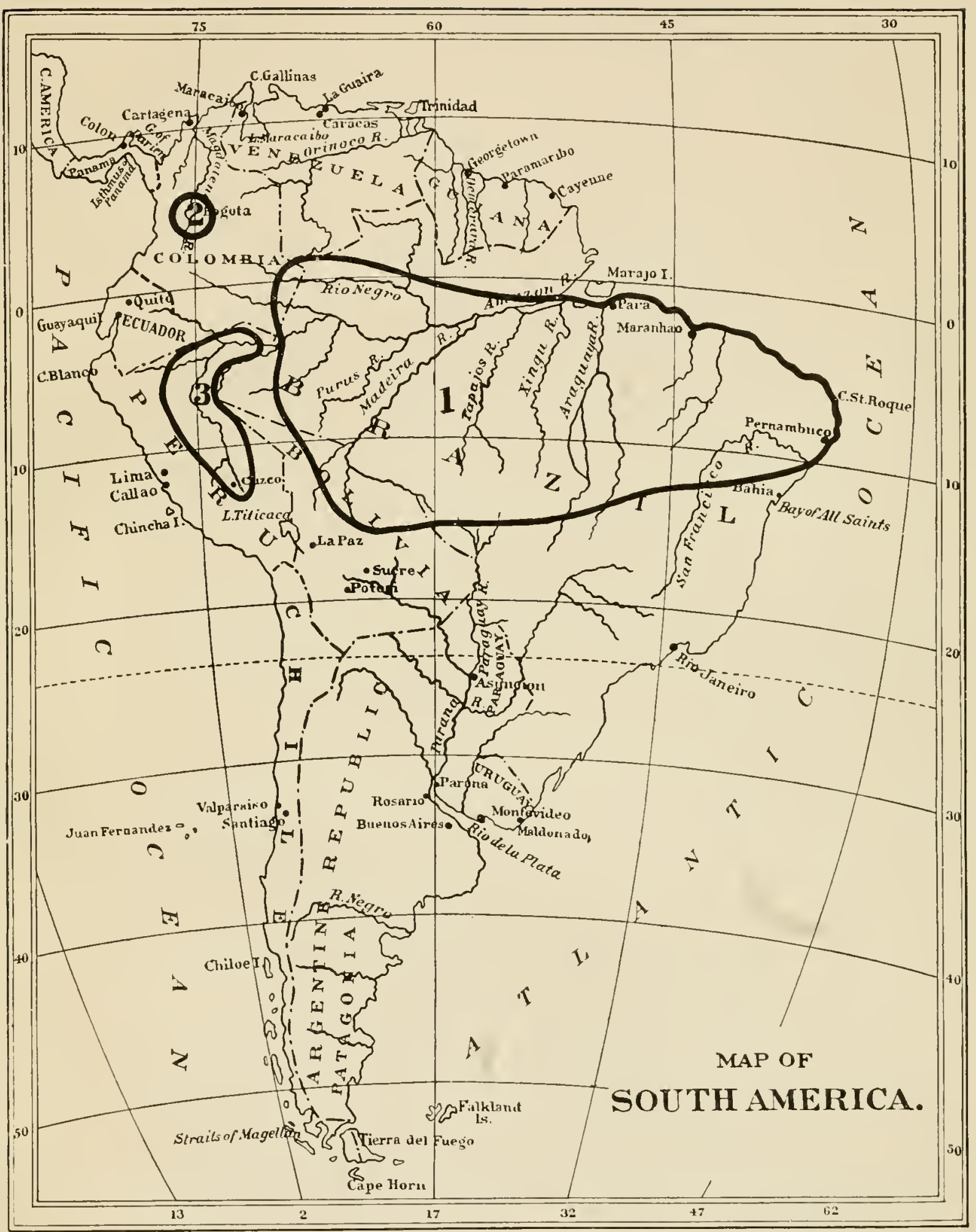

Breeding Ranges of the Subspecies of Chordeiles Rupestris.

1. Chordeiles rupestris rupestris.

2. Chordeiles rupestrix xyostictus.

3. Chordeiles rupestris zaleucus. 



\section{N D EX.}

[Figures in black-faced type indicate family, generic, specific, or subspecific headimgs.]

acutipennis, Caprimulgus........... $87,93,94,97$

Chordeiles...

$2,4,5,6,7,12,13,15,16,13,19,20,21$ $23,87,89,90,91,92,93,97,112$ Chordeiles acutipennis......... 1 , $13,14,15,16,24,31,89,90$, $91,92,94,95,96,97,98,99$, $100,102,104,105,110,111$

acutus, Caprimulgus.................. 93,94 albicollis, Caprimulgus................. \& 8 americanus, Caprimulgus............ 3, 20, 35, 42 Caprimulgus miror........ 20,35, 41 Siphonorhis................ 20

Antiurus.............................. 8

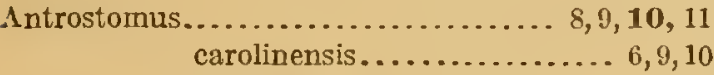
nelsoni................... 12 notabilis................. 12 vociferus................. 10 arizonae, Setochalcis vocifera............. $\quad 12$ aserriensis, Chordeiles virginianns......... 1, $14,15,16,25,29,30,31,33,34,49$, $55,61,62,67,71,72,73,74,76,80$

asio, Otus 96 badia, Setochalcis..................... $\quad 12$ brasilianus, Caprimulgus............ 93,94,97 Chordeiles acutipennis......... 97 Butorides virescens.................... 94 caberculatus, Caprimulgus.............. 21 Jamphaoratus............. 20 Caprimulgi......................... 9 Caprimulgidae................. (4, 7, 8, 9, 12, 22 Caprimulginae...................... 22 Caprimulgus................. $8,9,10,11,41,97$ acutipennis........... $87,93,04,97$ acutus.................... 93,94 albicollis................... 8 americanus........... 3, 20,35, 42 brasilianus............ $33,94,97$ caberculatus.............. 21 europaeus..............6, 6, 10,35 exilis............. 3, 21,93,98,99 guianensis............... 8 hirundinaceus.............. 97 jaspideus.................. 35, 42 labeculatus................ 21 macromystax.............. 12 minor americanus......... 20,35,41 nigrescens................ 97 noitibo................... 94 nuttallii................... 8 ocellatus................... 8 popetue...................... 35,42 $13732^{\circ}-$ Bull. 86-14-9
Page.

Caprimulgus pruinosus................ 3, 21, 98

rupestris.............20,113, 114 semitorquatus.............. 94 stenopterus................. 94 variegatus................ 35,42 virginianus.... $3,20,21,26,34,35,40,42$ vocilerus.................. 11

carolinensis, Antrostomus............. 6, 9,10 Cerchneis sparveria.................... 33

chapmani, Chordeiles popetue........... 34, 75 Chordeiles virginianus.......... 14, $15,16,24,29,30,31,33,34,39$, $40,127,75,76,77,78,80,82,83$

cliapensis, Setochal is vocifera........... 12 Chordediles........................ 3,21 minor................. $34,82,84$

Chordedilus.......................... $\quad 21$

Chordeiles........................... 1, 3 ,

$6,7,8,9,12,13,15,17,18,19,20,21,22,23$ acutipennis........... $1,2,4,5,6,7,12$,

$13,15,16,18,19,20,21,23$,

$\mathbf{8 7}, 89,90,91,32,93,97,112$ acutipennis........ 1 , $13,14,15,16,21,31,89,90$, $91,92,94,95,96,97,98,99$, $100,102,104,105,110,111$ brasilianus.......... 97 exilis..... 1, 14, 15, 16, 24, 89 , $90,91,92,95,98,99,100,101$ inferior. . 14, 16, 24, 89, 90,91, $92,93,103,104,105,109,111$ micromeris......... 14, $15,16,24,89,90,91,92,93$, 100, 102, 103, 104, 109, 111 pruinosus.......... 99 texcusis.. $6,14,16,24,89,90$,

$91,92,102,103,105,108,109$ gundlachii.............. 1, $82,84,85$ henry..................... 63 henryi................. 34, 63, 65,68 labeculatus................... 94 peruvianus.................... 98 popetue chapmani............ 34,75 sennetti........... 52,73

pusillus. ................... 20 rupestris........... 1, $4, \pi, 12,13,15$,

$19,23,113,114,117,118,120$ rupcstris............ 1 , $14,15,16,23,113,114,116$ xyostictus.......... 14, 15,

$16,23,114,116,117,118,120$ zaleucus. . 14, 15, 16, 23, 114, 118 sapiti...................... 94 
Chordeiles texensis.................... $\begin{aligned} & \text { Page. } \\ & 93,103\end{aligned}$ virginianus.............. 1,2,3,4,5, $6,7,12.13,15,16,18,19,20$, 21, $26,28,29,30,31,32,34$, $42,61,77,83,86,87,88,89,92$ aserrieusis......... 1,14,

$15,10,25,29,30$, $31,33,34,49,55$, $61,62,67,71$, $72,73,74,76,80$ chapmanl..... 14, 15, 16, 24 , $25,29,30,31,33$, $34,39,40,47,75$, $76,77.78,80,82.83$ henryi............ 14, 16, $24,25,23,30,31,34$, $48,59,61,62,63,64$, $65,66,67,68,70,71$ hesperis........... 14, $16,25,26,28,29$, $30,31,33,34,38$, $39,46,48,49$, $51,52,53,54,59$, $60,61,62,65,66$, $72,73,76,80,97$ howelli........... 14, 16 $25,29,30,31,33,34$, $38,47,48,49,54,55$, $5 \%, 61,62,63,64$, $65,66,67,71,72,110$ minor ............. 1,13, $14,16,24,25,29$, $30,31,33,82,84,85$ sennetti............14, 16 $25,26,29,30,31,33,34$, $38,39,47,48, \mathbf{5 2}, 54$, $55,56,57,59,60,62,66$, $71,72,73,74,76,80,99$ vicinus............ 14,16 , $25,29,30,31,33$, $34,80,81,83,84$ virginianus....... 1, 14, 15 , $16,25,26,29,30$, $31,32, .33,35$, $38,39,40,41$, $42,45,46,47,48$, $49,53,54,55,59$, $66,75,76,77,83$

Chordeilidaß......................... 3, 8, 9,

Chordeilus.............................. 3,21

Chordiles............................... 3,21

pruinosus..................... 99

prumosus...................... 99

semitorquatus................... 3,98

cosmetornis........................... 8 Crapaud-volant ou tette chevre de la Guiane.. 94,97 cubanensis, Setochalcis.................. 12 Cypsehiær.

East India bat.

Eleothreptus. 22

8

Engoulevent acutipenne de la Guyane.... 93,94,97 ouropaeus, Caprimulgus............. 6,9, 10,35 Eurostopodus.

exilis, Caprimulgus. . . ............ 3,21,93,98,99 Chordeiles acutipennis........... 1,14,15, $16,24,89,90,91,92,95,98,99,100,101$
Page.

exilis, Ramphaoratus................... 20

goatsucker ........................... 10,42

longwinged.................. 35, 42

Virginia..................... 35

goldmani, Sotochalcis ridgwayi............. 12

crackle............................. ${ }_{22}$

guianensis, Caprimulgus................. 8

gundlachii, Chordeiles................ 1,82,84,85

hawk, sparrow ....................... 33

herury, Chordeiles....................... 63

henryi, Chordeiles.................. 34, 63, 65,68

Chordeiles virginianus........... 14, 16,

$24,25,29,30,31,34,48,59,61$,

$62,63,64,65,66,67,68,70,71$

hesperis, Chordeiles virginianus........... 14, 16 ,

$25,26,28,29,30,31,33,34,38,39,46,48,49,51$,

$52,53,54,59,60,61,62,65,66,72,73,76,80,97$

hirundiuaceus, Caprimulgus............. 97

Nytipolus................. 20,97

howelli, Chordeiles virginianus ........... 14, 16,

$25,29,30,31,33,34,38,47,49,49,54,55$,

$\mathbf{5 7}, 61,62,63,64,65,66,67,71,72,110$

hwipperiwill........................ 35,42

Hydropsalis ............................. 8

inferior, Chordeiles acutipenuis........... 14,

$16,24,89,90,91,92,93,103,104,105,109,111$

jaspideus, Calurimulgus................... 35,42

labeculatus, Caprimulgus................ 21

Chordelies................. 94

leucopterus, Nyctibius.................. $\quad 20$

leucopyga, Nyctiprogne................. 20

longwinged goatsucker................. 35, 42

Lurocalis............................. 7,8

nattereri...................... 20

semitorquatus..................20,91

Lyncornis............................ 8

Macrodipteryx....................... 8

macromystax, Caprimulgus............... $\quad 12$

Setochalcis vocifera......... 12

Macropsalis........................... 8

Macropterygidas....................... 22

merrilli, Nyctidromus albicollis ............ $\quad 6$

micromeris, Chordeiles acutipennis........ 14, $15,16,24,89,90,91,92,93$, $100,102,103,104,109,111$

Microrlynchus....................... 3, 20

minor, Chordeiles. ................... $34, \$ 2,84$

Chordeiles virginianus............ 1, 13, $14,16,24,25,29,30,31,33,82, \$ 4, \$ 5$

Nannochordeiles................. 3, $7,8,12,20$

nattereri, Lurocalis...................... 20

nelsoni, Antrostomus................... 12

nighthawk. ..... 1, 19, 20,32, 33, 42, 49, 73, 76, 93, 106

Sennett.................... 55

nigrescens, Caprimulgus ................ 97

noitibo, Caprimulgus.....................

notabilis, Antrostomus................... 12

uuttallii, Caprimulgus.................... \&

Phalaenoptilus................... 6

Nyctagreus.......................... \& \&

Nyctibius leucopterus.................... 20

Nyctidromus...................... $\$, 10$

albicollis merrilli............. 6

Nyctiphrynus.......................... 8

Nyctipolus . $\ldots \ldots \ldots \ldots \ldots \ldots \ldots \ldots \ldots \ldots . . . \ldots, 97$

hirundinacous............. 20,97 
Page.

Nyctiprogne....................... 3,7,8,12

leucopsga................. 20

oaxacae, Setochalcis rocifera .............. 12

ocellatus, Caprimulgus.................... s s

otiosa, Setochalcis rufa .................. 12

Otophanes............................ 8

Otus asio.............................. 96

owl................................. 93

parrot................................ 22

peruvianus, Chordeiles.................. 98

Phalaenoptilus....................... 8

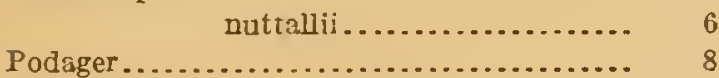

Podargidae........................... 22

popetue, Caprimulgus.................. 35,42

pruinosus, Caprimulgus................. 3,21, 98

Chordeiles acutipennis.......... 99

Pamphaoratus.................. 20

prumosus, Chordiles.................... 98

Ptilonjeterus.......................... \&

pusillus, Chordeiles....................... 20

Ramphaoratus ....................... $3,20,21$

caberculatus............... 20

exilis.................... 20

pruinosus................. 20

truncatus................20,21

ridgwayi, Setochalcis.................... 12

Setoclalcis ridgwayi............ 12

rufa, Setochalcis rufa.................. 12

rupestris, Caprimulgus.............. 20,113,114

Chordeiles ................... 1,4,

$5,12,13,15,19,23,113,114,117,118,120$

Chordeiles rupestris ............. 1,

$14,15,16,22,113,114,116$

saivini, Setochalcis..................... 12

sapiti, Chordeiles........................ 91

saturata, Setochalcis..................... 12

Scotornis........................... \&

semitorquatus, Caprimulsus............... 91

Chordeiles............... 3,98

Lurocalis............... 20,94

sennetti, Chordeiles popetue.............. 52,73

Chordeiles rirginianus ............ 14,

$16,25,26,29,30,31,33,34,38,39,4 \vec{\imath}, 48$,

$52,51,55,56,57,59,60,62,66,71,72,73$, $74,76,50,99$.

Sennett nighthaw $k$

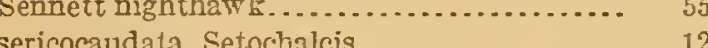

Setochalcis....................... $8,10,11$

badia...................... 12

cubanersis................... 12
Page.

Setochalcis ridgwayi...................... 12

goldmani.............. 12

ridgwayj.............. 12

rufb otiosa . .................. 12

rufa................... 12

sal rini....................... 12

saturata.................... 12

sericocaudata................. 12

vocifera..............6, $7,34,41,42$

arizonae............... 12

chiapensis............. 12

macromystax........... $\quad 12$

oaxacae............... 12

rocifera.............. 12

Siphonorhis............................ 8

americanus.................. 20

sparrow hawk......................... 33

sparveria, Cerchneis...................... $\quad 33$

Stenopsis............................ 8

stenopterus, Caprimulgus................. 94

Systellura............................. 8

texensis, Chordeiles..................... 93

Chordeiles acutipennis........... 6,14,

$16,24,89,90,91,92,102,103,105,108,109$

Trochilidae........................... 22

truncatus, Ramphaoratus............... 20,21

variegatus, Caprimulgus................... 35, 42

vicinus, Chordeiles virginianus.............. 14, $16,25,29,30,31,33,34,80,81,83,84$

virescens, Butorides ..................... 84

Virginia goatsucker.................... $3 \overline{5}$

rirginianus, Caprimulgus............... 3, 20,

$21,26,34,35,40,42$

Chordeiles.......... $1,2,3,4,5,6,7$,

$12,13,15,16,18,19,20,24$,

26, $25,29,30,31,32,34,42$,

$61,77,83,86,87,88,89,92$

Chordeiles virginianus.. 1, 14, 15, 16, 25, $26,29,30,31,32,33,35,38$, $39, \frac{10}{2}, 41,42,45,46,47,48,40$, $53,54,55,59,66,75,76,77,83$

vocifera, Setochalcis..............6, $7,34,41,42$

Setochalcis rocifera............ 12

vociferus, Antrostomus................. 10

Caprimulgus................... 11

whip-poor-will.................. 20,35,41, 42

whip-pour-will......................... 35

xyostictus, Chordeiles rupestris.........14,15, 16 ,

$23,114,116,117,118,120$

zaleucus, Chordeiles rupestris. $14,15,16,23,114,118$ 






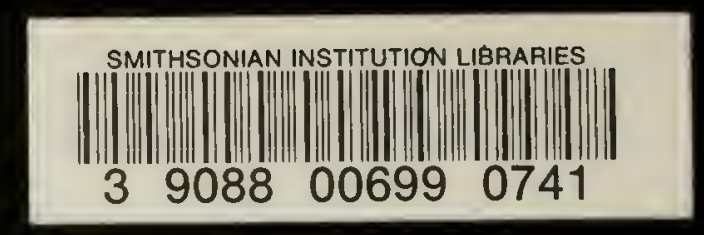

